fossil Enengy Phogram

\title{
Survey of Industrial Coal Conversion Equipment Capabilities: Valves
}

\author{
W. A. Bush \\ E. C. Slade
}

OAK RIDGE NATIONAL LABORATORY OPERATED BY UNION CARBIDE CORPORATION - FOR THE DEPARTMENT OF ENERGY 


\section{DISCLAIMER}

This report was prepared as an account of work sponsored by an agency of the United States Government. Neither the United States Government nor any agency Thereof, nor any of their employees, makes any warranty, express or implied, or assumes any legal liability or responsibility for the accuracy, completeness, or usefulness of any information, apparatus, product, or process disclosed, or represents that its use would not infringe privately owned rights. Reference herein to any specific commercial product, process, or service by trade name, trademark, manufacturer, or otherwise does not necessarily constitute or imply its endorsement, recommendation, or favoring by the United States Government or any agency thereof. The views and opinions of authors expressed herein do not necessarily state or reflect those of the United States Government or any agency thereof. 


\section{DISCLAIMER}

Portions of this document may be illegible in electronic image products. Images are produced from the best available original document. 


\section{Printed in the United States of America. Available from National Technical Information Service \\ U.S. Department of Commerce \\ 5285 Port Royal Road, Springfield, Virginia 22161 \\ Price: Printed Copy $\$ 9.00$; Microfiche $\$ 3.00$

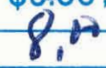

This report was prepared as an account of work sponsored by an agency of the United States Government. Neither the United States Government nor any agency thereof, nor any of their employees, contractors, subcontractors, or their employees, makes any warranty, express or implied, nor assumes any legal liability or responsibility for any third party's use or the results of such use of any information, apparatus, product or process disclosed in this report, nor represents that its use by such third party would not infringe privately owned rights. 


\author{
Contract No. W-7405-eng-26 \\ UCC-ND Engineering
}

\section{SURVEY OF INDUSTRIAL COAL CONVERSION \\ EQUIPMENT CAPABILITIES: VALVES}
W. A. Bush
E. C. Slade

Date Published: June 1978

This report was prepotice -

sponsored by the United States an account of work Energa States nor the United States Departicher the cantractors any of their employees, nor any of tof any wars, subcontractors, or their employe of their liability or rexperss or implied, or assumes any les or use or responsibility for the accuracy, completegas process discess of atiy infomation, apparat compieterentess infringe privased, or represents that its use producl or .

OAK RIDGE NATIONAL LABORATORY

Oak Ridge, Tennessee 37830

operated by

UNION CARBIDE COKPOKATION

for the

DEPARTMENT OF ENERGY

DISTREBUUIION OF THIS DOCUMENT IS UNLIMTED 
CONTENTS

$\underline{\text { Page }}$

Foreword and Acknowledgments . . . . . . . . . . . . . . v

Abstract . . . . . . . . . . . . . . . . . . . I 1

1. INTRODUCTION . . . . . . . . . . . . . . . . . . . 1

2. SUMMARY . . . . . . . . . . . . . . . . . 3

3. COAL CONVERSION PROCESSES . . . . . . . . . . . . . 5

4. VAlve SURVEY . . . . . . . . . . . . . . . . 15

4.1 Method .. . . . . . . . . . . ..... 15

4.2 Response to Survey . . . . . . . . . . . . . . 16

4.3 Valve Survey Results ................. 16

Lock-Hopper Feed Valves. . . . . . . . . . 16

Slurry Feed Valves ............... 21

Slag-Char Letdown Valves . . . . . . . . . 21

Gas, Steam, Oxygen Valves... . . . . . . . . 21

Flow Interruption and Equipment Isolation

Valves . . . . . . . . . . . . . 22

5. VALVE ACTUATOR SURVEY . . . . . . . . . . . . . . . . 23

5.1 Method . . . . . . . . . . . . . . . . . 23

5.2 Response to Survey . . . . . . . . . . . . . . . . 23

5.3 Actuator Survey Results . . . . . . . . . . . . 24

6. ANALYSIS OF SURVEY RESULTS . . . . . . . . . . . . 25

6.1 Background . . . . . . . . . . . . . . . . . . 25

6.2 Technology . . . . . . . . . . . . . . . . . 25

6.3 Valve Specification . . . . . . . . . . . . . 26

6.4 Limiting factors... . . . . . . . . . . 27

Materials................. 27

Design .................. 27

Testing Facilities . . . . . . . . . . . 28

6.5 Impact . . . . . . . . . . . . . . . . . . . . 28

6.6 Potential Problem Areas . . . . . . . . . . . . . 28

Industrial Economic Improvement . . . . . . . 29

Alloy Availability . . . . . . . . . . . . 29

6.7 Availability Summary . . . . . . . . . . . . 29

Valves . . . . . . . . . . . . . . 29

Actuators.................. . 30

7. RECOMMENDATIONS . . . . . . . . . . . . . . . 31

REFERENCES ........................... . . . 33 
Appendix A. CAPABILITY RESPONSES OF VALVE MANUFACTURERS . . . . 35

Appendix B. CAPABILITY RESPONSES OF VALVE-ACTUATOR MANUFACTURERS . . . . . . . . . . . . . . 119

Appendix C. SAMPLE LETTER OF INQUIRY TO BALL VALVE MANUFACTURERS . . . . . . . . . . . . . . 141

Appendix D. SAMPLE LETTER OF INQUIRY TO BLAST/SLIDE/KNIFE EDGE VALVE MANIJGACTURERS . . . . . . . . . . . . . 147

Appendix E. SAMPT.F. LETTER OF INQUIRY TO VALVE-ACTUATOR MANUFACTURERS ................ 155

Appendix F. VALVE SIZE DETERMINA'IONS . . . . . . . . . . 161 
FOREWORD AND ACKNOWLEDGMENTS

This is one of four reports describing surveys of industrial coal conversion equipment capabilities which were conducted for and supported by the Equipment Branch (James Powel1, Branch Chief, and T. K. Lau, Project Manager) of the Fossil Energy Major Facilities Project Management Division (MFPM)* of the Energy Research and Development Administration (ERDA).* This report describes the results of the survey relating to valves; other reports in this series are:

- J. P. Meyer and M. S. Edwards, Survey of Industrial Coal Conversion Equipinent Capabilities; High Temperature, High Pressure Gas Purification, ORNL/TM-6072, Oak Ridge National Laboratory (1978).

- W. R. Gambill and W. R. Reed, Survey of Industrial Coal Conversion Equipment Capabilities: Heat Recovery and Utilization, oRNL/TM-6073, Oak Ridge National Laboratory (1978).

- W. R. Williams, J. R. Horton, W. F. Boudreau, and M. Siman-Tov, Survey of Industrial Coal Conversion Equipment Capabilities: Rotating Components, ORNL/TM-6074, Oak Ridge National Laboratory (1978).

This is the first of two reports planned on the subject of valves for the coal conversion industry. The report is limited to the availability of large, high-temperature stop valves. A second report will cover valve reliability, valve industry economics, and availability of pressurereducing (letdown) valves for application in coal conversion plants.

The authors express their appreciation to The Valve Manufacturers Association and to those in the industry who have given their time and effort to reply to our questionnaires and have met with us to discuss availability and problems of valves required by the coal conversion

*Effective October 1, 1977, ERDA became part of the Department of Energy (DOE); MFPM has since become part of the Division of coal conversion of DOE. 
industry. Without their cooperation, this report would not have been pusslble.

We also express our appreciation to many people in the Department of Energy, especially those at Morgantown Energy Research Center, and to many people in the Union Carbide Nuclear Division who have provided assistance during this study. 
SURVEY OF INDUSTRIAL COAL CONVERSION EQUIPMENT CAPABILITIES: VALVES

\author{
W. A. Bush \\ E. C. Slade
}

\begin{abstract}
A survey of the industrial capabilities of the valve and valve-actuator industry to supply large, high-pressure stop valves for the future coal conversion industry is presented in this report. Also discussed are development and testing capabilities of valve and valve-actuator manufacturers and anticipated lead times required to manufacture advanced design valves for the most stringent service applications. Results indicate that the valve and valveactuator industry is capable of manufacturing in quantity equipment of the size and for the pressure and temperature ranges which would be required in the coal conversion industry. Valve manufacturers do not, however, have sufficient product application experience to predict the continuing functional ability of valves for some of the required applications.
\end{abstract}

\title{
INTRODUCTION
}

With the increased realization of shortages of oil and natural gas and with increased U.S. dependence on foreign oil, serious attention is being given. to the commercialization of advanced processes for the conversion of coal to clean liquids and gases. A number of these processes have been under development for many years; many additional processes are currently being studied." Of these processes, some are in the pilot-plant stage, others are ready for scale-up to demonstration-size units, and still others are ready for commercialization. There are many existing conceptual designs for coal conversion facilities based on such processes. The question now is whether or not the equipment specified in such designs is indeed readily available from U.S. industry. If not, the question becomes one of determining how much lead time is required to develop such equipment. 
The potential to have demonstration and commercial coal conversion facilities in timely production depends in part on the availability of the necessary equipment and in part on the time required for construction of the facilities. The Major Facilities Project Management Division (MFPM) of the Energy Research and Development Administration, Fossil Energy Division, was charged with the task of overseeing the commercialization of coal conversion in the United States. This study, which supports the efforts of MFPM, was initiated with a twofold objective:

1. determination of present capabilities of U.S. industry to supply equipment needed for future demonstration and comnercial coal conversion facilities and

2. identification of problem areas as well as determination of research and development needs for producing equipment of advanced design, including lead time requirements.

The total project includes all types of equipment found in a coal conversion plant; however, only four categories have been studied this year: valves, hot-gas cleanup devices, heat recovery equipment, and rotating equipment. This report addresses only the first category, valves and their actuators. Three additional reports covering the other equipment categories are being issued concurrently with this report. 1-3

This report on valves is limited to the capability of the valve industry to manufacture 6-in.-diam and larger stop valves for applications at temperatures above $300^{\circ} \mathrm{F}$. Sections of this report concern coal conversion processes, methods used in surveying the valve and valveactuator industry, responses to the survey, and an analysis of the survey results, which includes limiting factors in the availability of valves as well as potential problem areas. 
To evaluate the valve requirements associated with coal conversion, seven prospective coal conversion design concepts were studied, flow streams were determined, valve types were assigned, and the valves were sized. It currently appears that the coal conversion processes operate in the range of the petrochemical industry, except for that portion of the process in which coal is converted to gas and oil. The analysis resulted in the identification of 24 high-temperature stop-valve applications that appeared to be more stringent than needed by the petrochemical industry. To determine the industry's capability to supply valves for these applications, questionaires were mailed to 231 valve manufacturers and to 49 valve-actuator manufacturers.

Results of the survey show that the valve and valve-actuator industry is capable of manufacturing equipment in quantity of the size and for the pressure and temperature ranges required by the coal conversion industry. Valve manufacturers do not, however, have sufficient product application experience to predict the continuing functional ability of valves used for lock-hopper feeders, slurry feeders, and slag-char letdown service. Developmental and testing efforts to modify existing valve designs or to develop new valve concepts for these applications were estimated to range from 1 to 6 years. A testing facility to simulate actuation of critical valves under service conditions would be beneficial. 
THIS PAGE

\section{WAS INTENTIONALLY LEFT BLANK}




\section{COAL CONVERSION PROCESSES}

To determine the valve requirements of the coal conversion industry, a study was made of selected processes under development by. DOE and considered to be candidates for demonstration plants. Following are the processes studied and the pressure-temperature requirements at the coal conversion reactor.

\section{Process}

High Btu gasification

BCR BI-GAS

IGT HYGAS

Fischer-Tropsch

Low Btu gasification

Lurgi

Liquefaction

Coalcon

Hydrocarbonization (U.S. Steel clean coke)

\section{Reactor condition}

Pressure (psi)

$1700-2700$

1200 850

470 1700 450 1000 1000 1000 150 1380

Synthoi1 4500

Plant designs for these processes are not complete enough to delineate the type of valves, valve sizes, or duty requirements. To predict these valve parameters, preliminary process design concepts that listed material flow quantities and operating conditions were studied, major lines were sized, and valves were assigned at conventional locations.

In a simplistic description, a coal conversion plant consists of a series of processing blocks. Figures 1 through 7 show the blocks for the seven processes studied. The operational conditions at most of these blocks are fairly well defined from an existing technological base - the petrochemical industry. As such, the valves in these portions of the plant are fairly standard, they exist, they function fairly well, and they are continually being improved upon as problems are recognized and as new materials are developed. However, the operational conditions in 


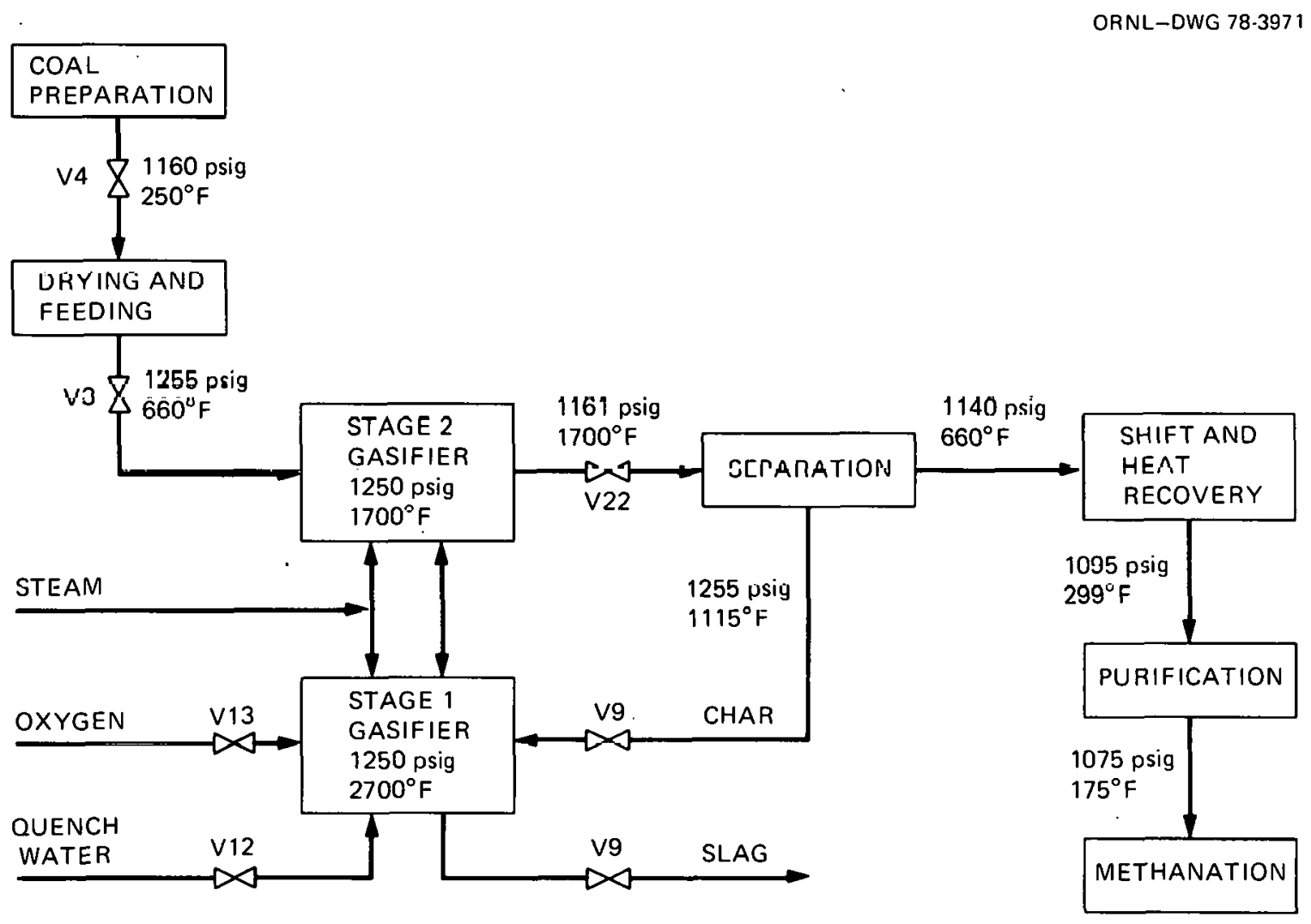

Fig. 1. Bituminous coal research BI-GAS process evaluation. Source: Energy Research and Development Administration, 250-MiZZion-SCFD High BTU Gas Plant, ERDA-76-48, Process Evaluation Group - Mineral and Material Research and Development, Morgantown, W. Va. (March 1976). 


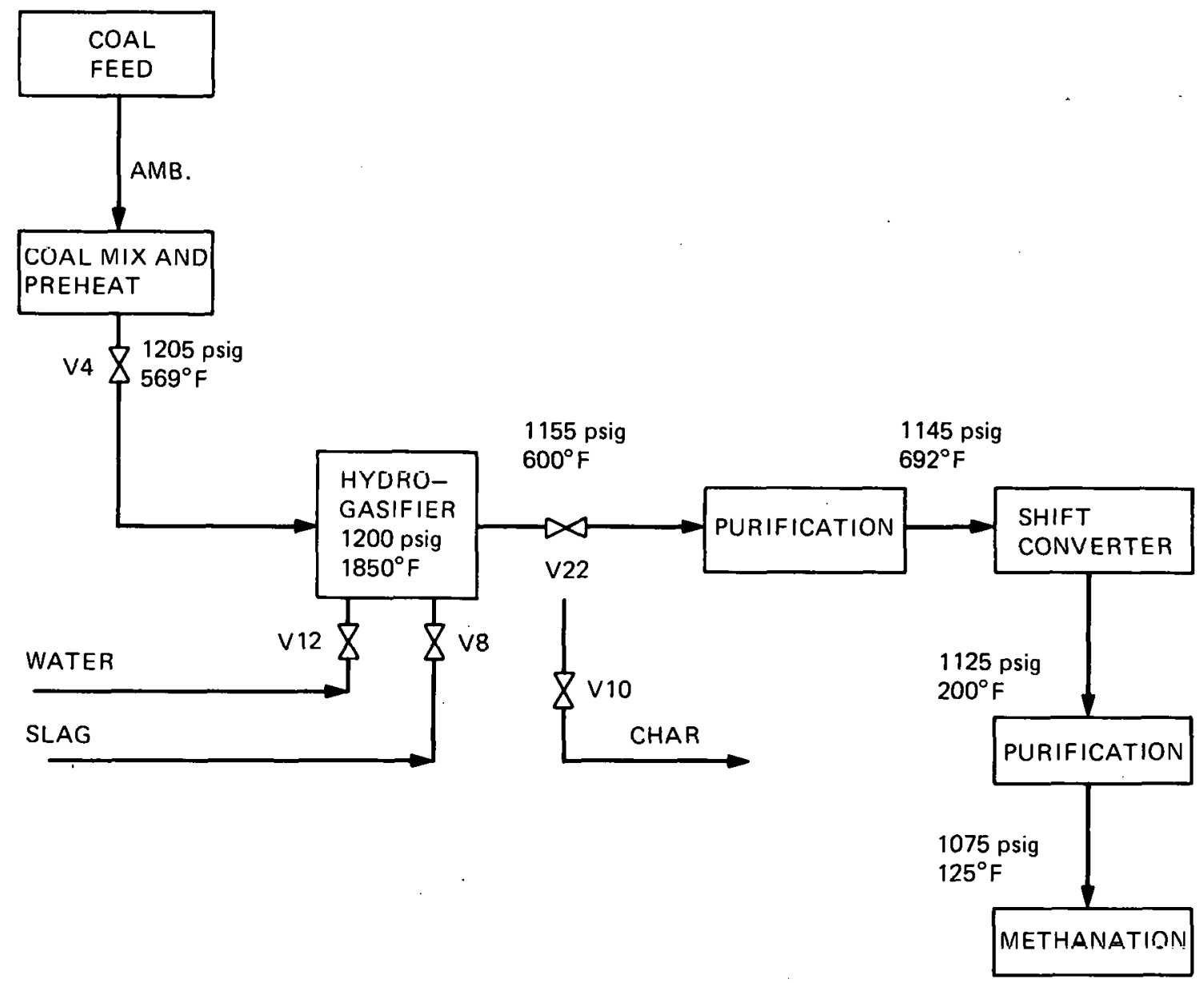

Fig. 2. IGT HYGAS process evaluation. Source: Energy Research and Development Administration, IGT HYGAS Hydrogasification Process, ERDA 76-47, Process Evaluation Group - Mineral and Material Research and Development, Morgantown, W. Va. (March 1976). 
ORNL-DWG 78.3969

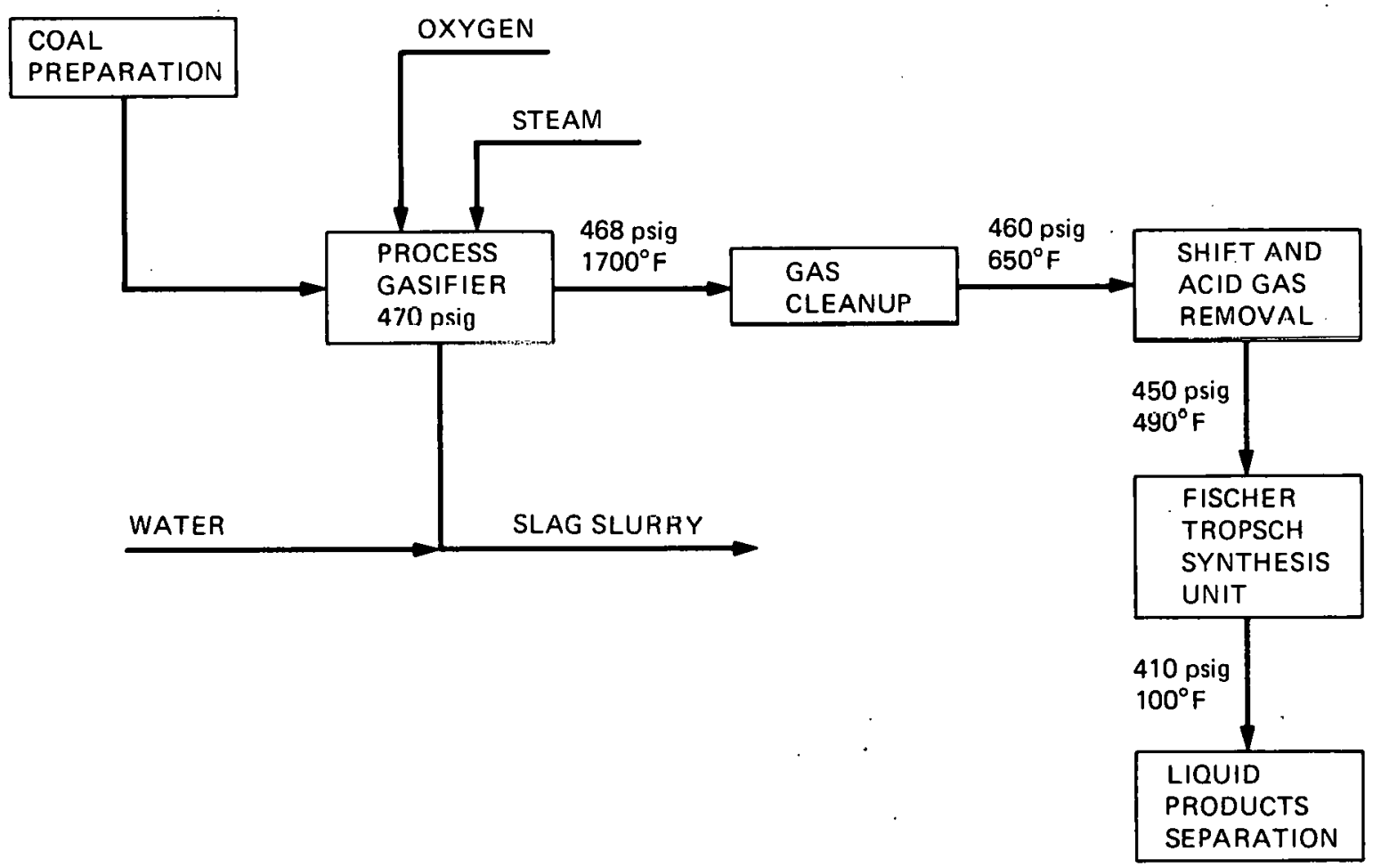

Fig. 3. Fischer-Tropsch process evaluation. Source: The R. M. Parsons Company, F'ischer-Tropsch Complex. Conceptual Design/Economies Analysis: OiZ and SNG Production. R\&D Repnrt. Nn. 114 - Intorim Raport No. 3, FE-1775-7, Pasadena, Calif. (January 1977). 
ORNL-DWG 78-3968

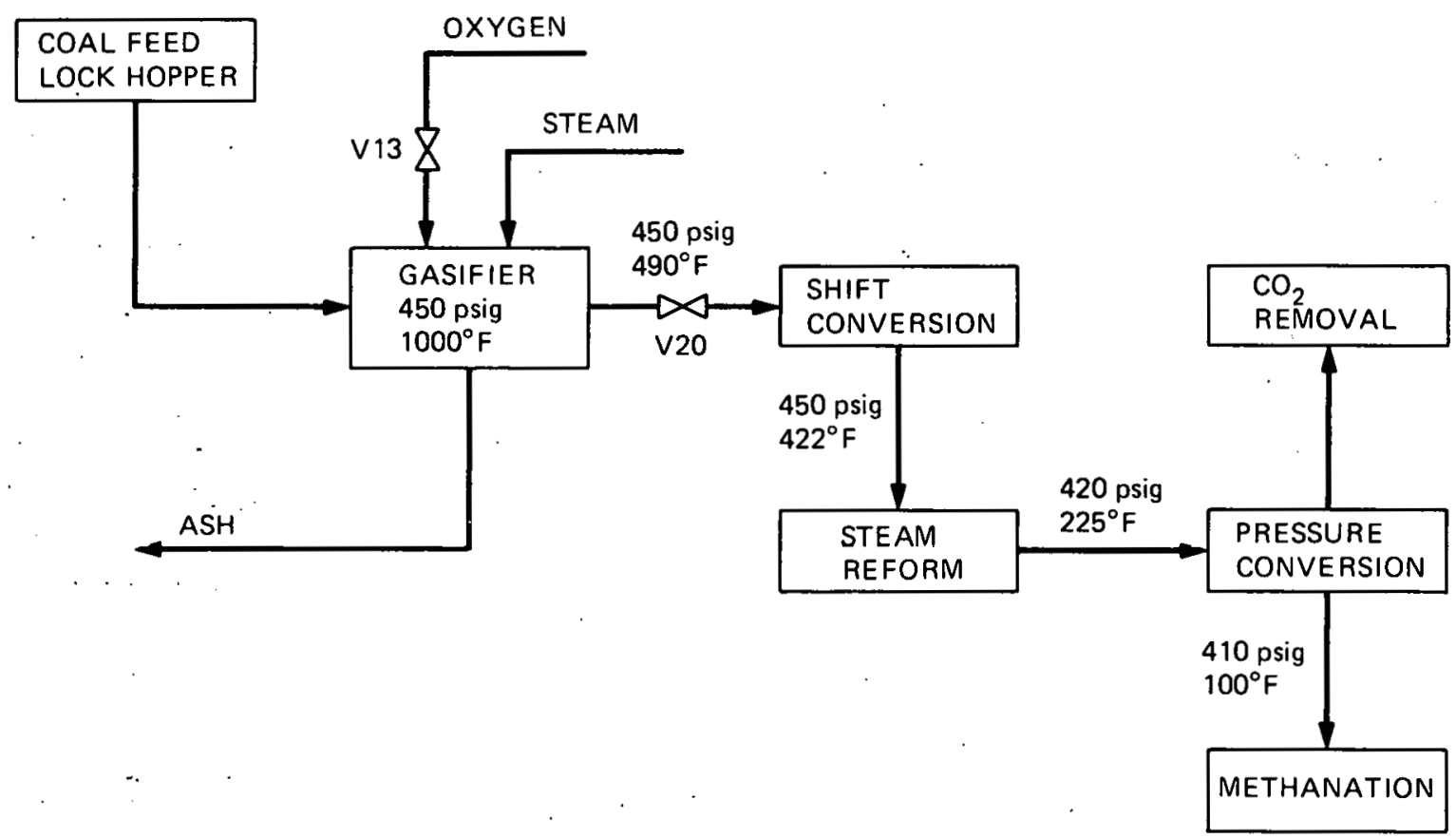

Fig. 4. Lurgi process evaluation. Source: Energy Research and Development Administration, 250-MiZZion-SCFD Gas Plant, ERDA 76-7, Process Evaluation Group - Mineral and Material Research and Development, Morgantown, W. Va. (August 1975). 


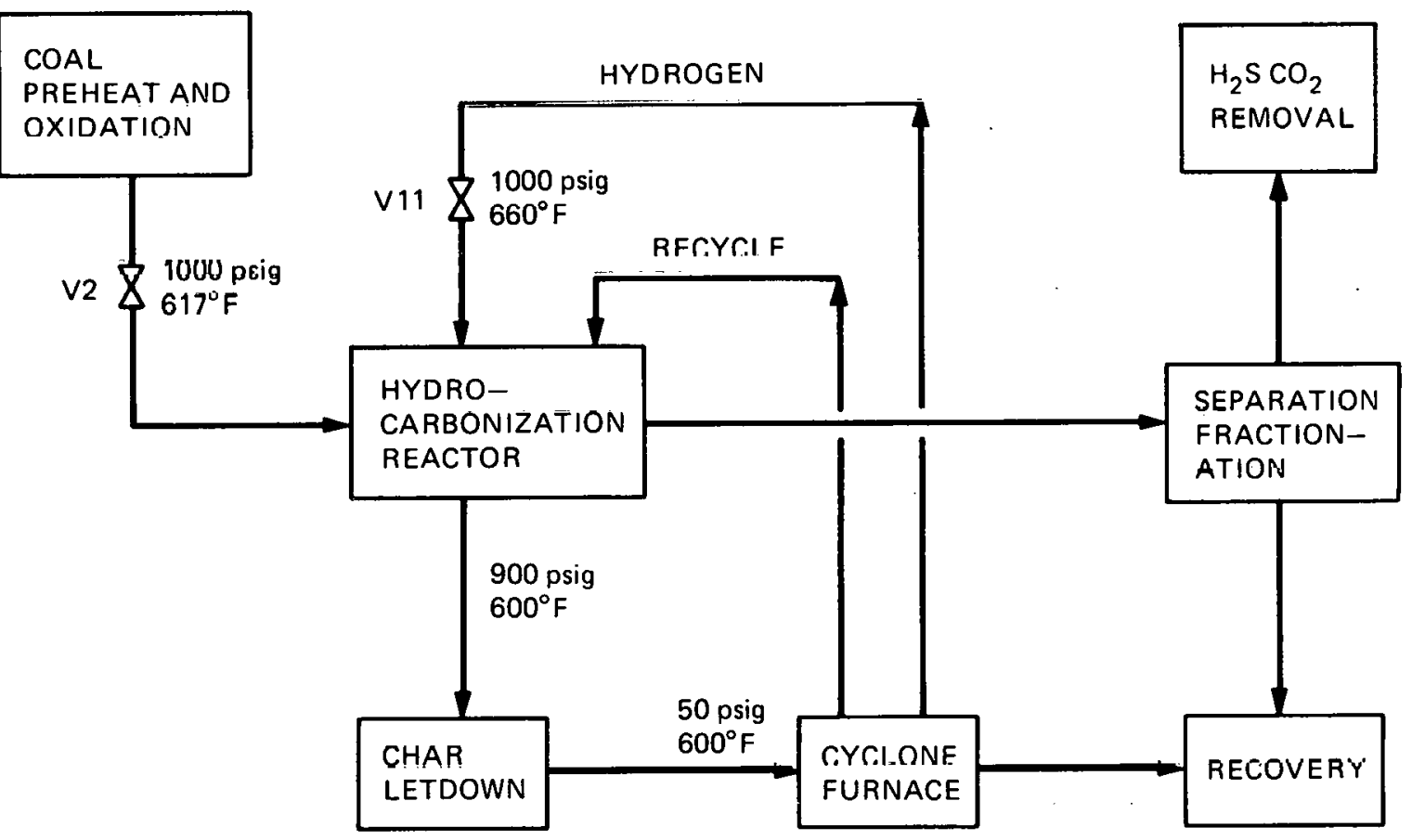

Fig. 5. Coalcon conceptual design analysis. Source: E. T. Coles, Commercial Plant Frocess Ëvaluation, report prepared under Contract No. E(49-18)-1736 with Energy Research and Development Administration, Coalcon, New York (August 1975). 
COAL

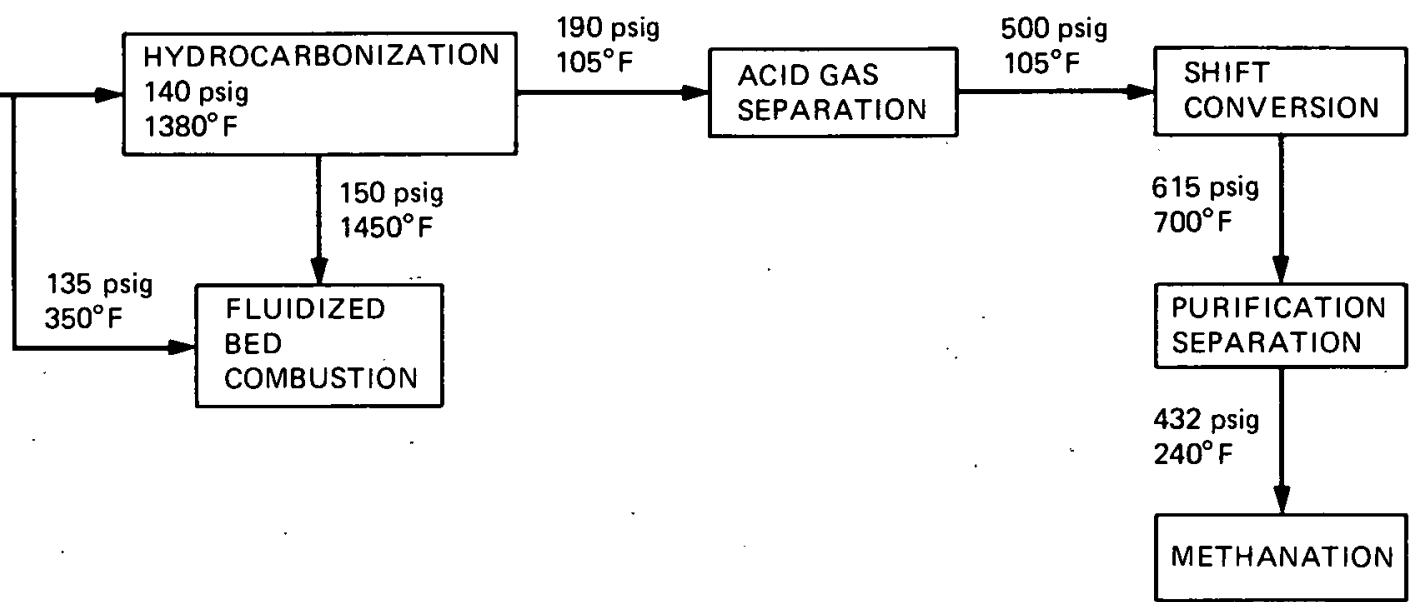

Fig. 6. Hydrocarbonization (U.S. Steel clean coke process). Source: J. M. Holmes et al., Hydrocarbonization Process Evaluation Report, ORNL-5212 (Draft) (September 1976). 
ORNL-DWG 78-3965

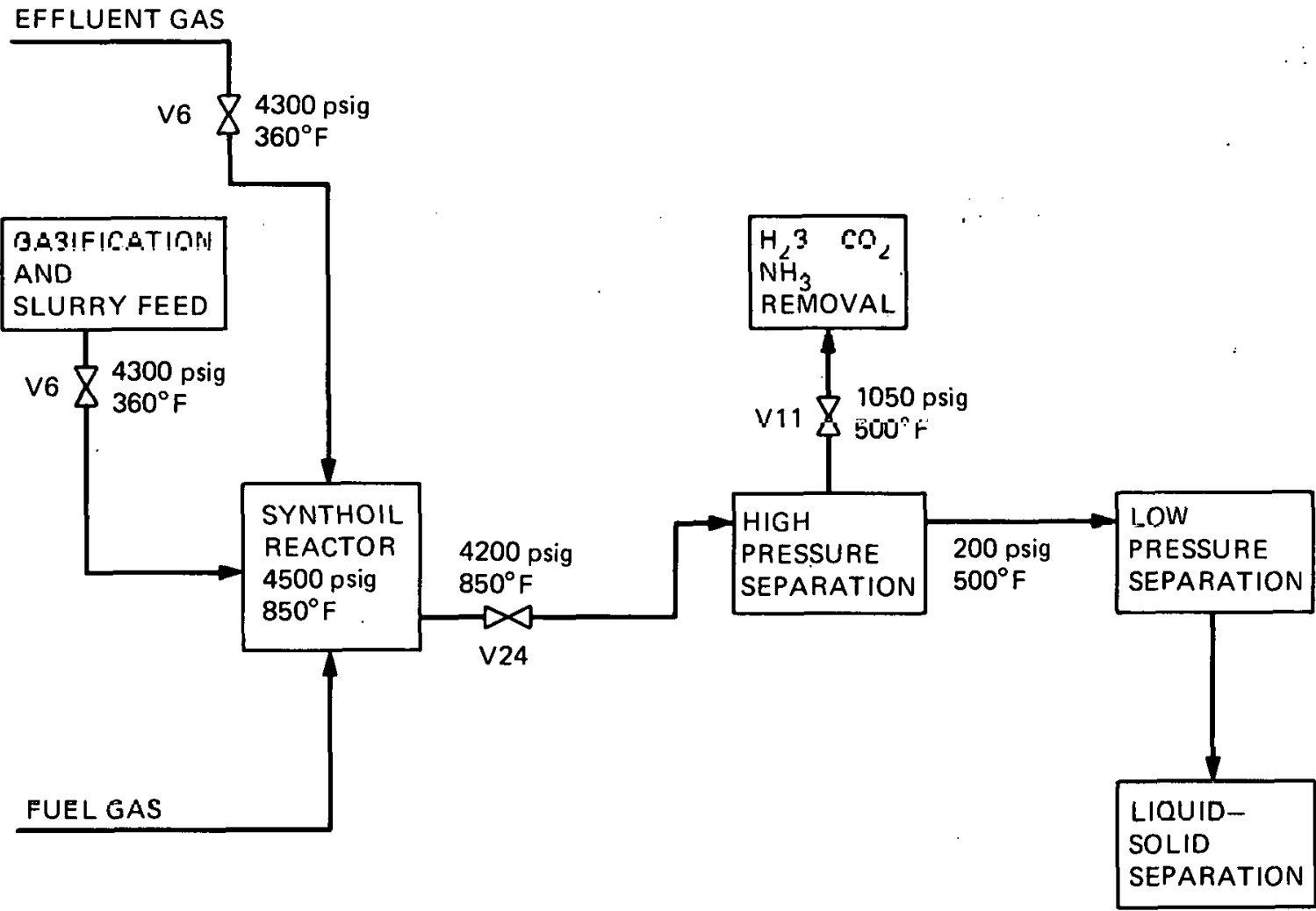

Fig. 7. Synthoil process evaluation. Source: R. Salmon et al., Evaluation of the Synthoil Process, ORNL-5209 (September 1976). 
the blocks in which coal conversion takes place are not well defined. Valve duty requirements are not fully known; there is no application or closely allied experience with which to ascertain the type of valve that should be used.

The charts of the individual conversion processes (Figs. 1-7) show the potential problem areas. Valves that were considered to be representative of the most stringent service requirements are denoted on the figures by a "V-number." 
THIS PAGE

\section{WAS INTENTIONALLY LEFT BLANK}


4. VALVE SURVEY

\subsection{Method}

The large high-pressure, high-temperature valves that appear to present new applications and would have the most stringent service requirements in the coal conversion industry have been identified on the block diagrams presented in the previous section. These valves can be classified as follows:

- Lock hopper valves

- Slurry feed valves

- Slag-char letdown valves

- Gas, steam, and oxygen valves

- Flow-interruption valves

- Equipment-isolation val.ves

The most likely valve configuation, valve size, and operating condition were sent to 231 valve manufacturers with the request that they identify products that they manufactured and that could be used for these service applications. The manufacturers were also requested to furnish information on their production, developmental and testing capabilities, and long-range plans for product development (see Appendixes $C$ and D).

The valve manufacturers surveyed were identified from the following sources:

- Morgantown Energy Research Center's previous state-of-the-art valve survey ${ }^{4}$

- The Valve Manufacturers Association's membership list ${ }^{5}$

- Chemical Engineering Buyer's Guide ${ }^{6}$

- Heating, Piping, and Air Conditioning's Product Directory ${ }^{7}$

- Thomas Register's catalog of companies ${ }^{8}$ 


\subsection{Response to Survey}

A luajority of the valve manutacturers responded to the survey (see Fig. 8). In general, no responses were received from companies that do not manufacture the large high-pressure, high-temperature type of valves itemized in the questionnaire.

Table 1 lists the companies who responded that they either manufactured or were interested in manufacturing the valves identified in the questionnaire.

\subsection{Valve Eurvey Results}

Results of the survey show that manufacturers have facilities to manufacture valves to the pressure-temperature conditions required for the most stringent applications in a coal conversion plant. Many of these manufacturers who have the facilities, however, are concerned by the service applications, particularly the solids in the flow stream. A summary of the responses, which indicates an availability of facilities and designs for the selected critical valves, is given in Table 2. Following is an overview of the responses.

\section{Lock-Hopper Feed Valves}

\begin{tabular}{cccc} 
V-number & $\begin{array}{r}\text { Pressure } \\
\text { (ps1) }\end{array}$ & $\begin{array}{c}\text { Temperature } \\
\left({ }^{\circ} \mathrm{F}\right)\end{array}$ & $\begin{array}{c}\text { Sizes } \\
\text { (in.) }\end{array}$ \\
\cline { 2 - 3 } V1 & 600 & 660 & $\frac{0,12,24}{6}$ \\
V2 & 1000 & 660 & $6,12,24$ \\
V3 & 1600 & 660 & $6,12,24$
\end{tabular}

The Morgantown Energy Research Center's (MERC) State-of-the-Art Valve Program and various DOE coal conversion pilot plants have been buying and testing valves for coal conversion application. In general, they have been dealing with valves smaller than 12 in., but most manufacturers feel confident that their products will prove to be satisfactory and that redesign of their products to larger sizes and for higher pressures and temperatures can be accomplished. 


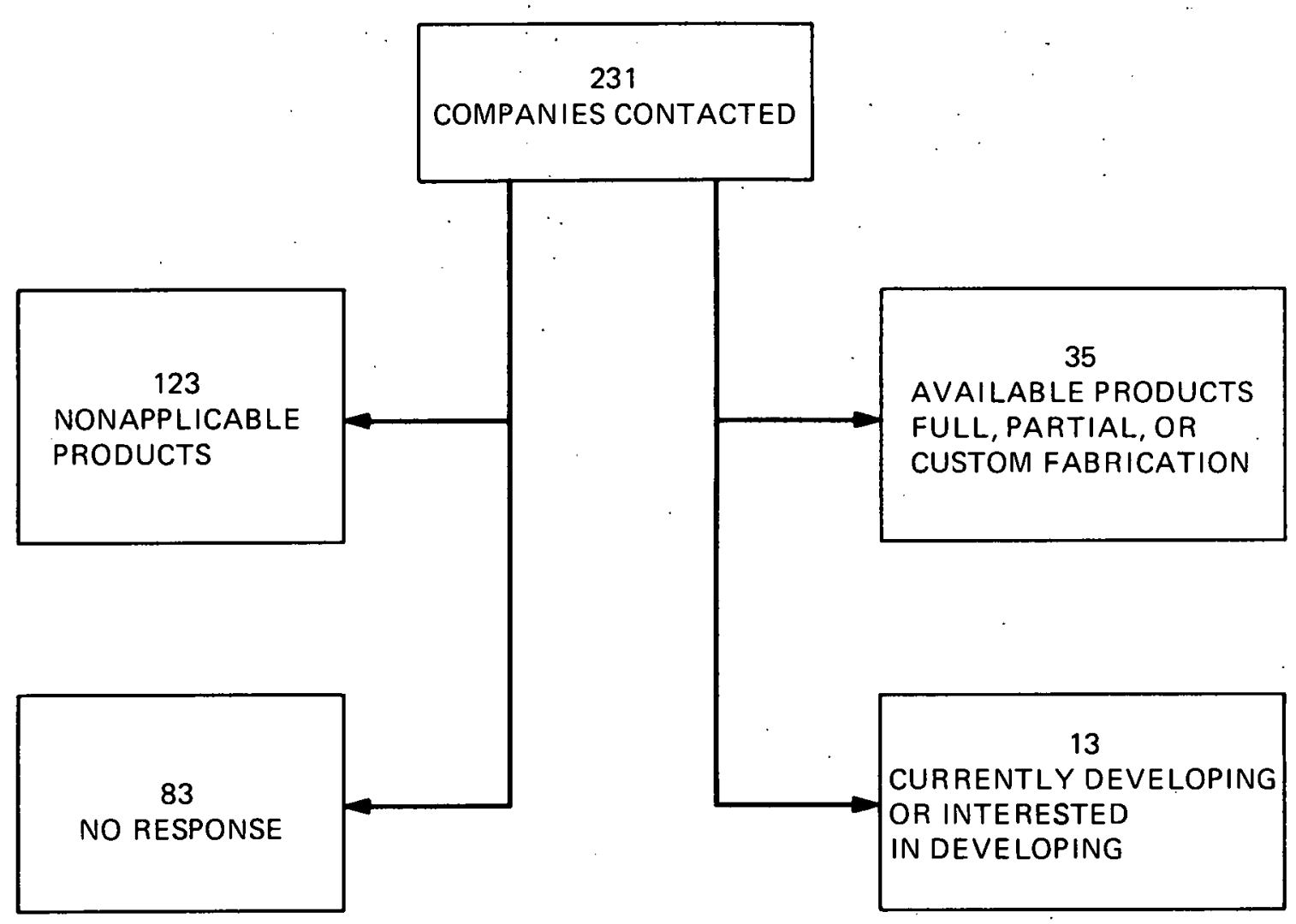

Fig. 8. Valve ourvey réspunse. 
Table 1. Valve survey summary

Available with qualifications:

full, partial, or custom fabrication

Not available: currently developing or interested in developing

ACF Industries, $\mathrm{W}-\mathrm{K}-\mathrm{M}$ Valve Division

Anchor/Darling Valve Co. Andco Industries

Atwood \& Morrill Co., Inc. Blaw-Knox Équ1pmenl, Inc. Cirmeron Iron Works, Ins. Clow Corp., Engineering Products Division

Consolidated Cintrols Corp. Crane Co.

DeZurik, Unit of General Signal

Dresser Industrial Valve \&

Inst. Division

Environmental Elements Corp.

Everlasting Valve Co.

Fabri-Valve

Fairchild Stratos

Fetterolf Corp.

Fisher Controls Co.

Fox Valve Development Co.

Gemco, the General Machine Co.

H111s-lucanina Co.

Honeywell, Inc.

Kamyr Valves, Inc.

Kicley and Mue.1.ler, Inc.

Powell, Wï., Cu., The

KKL Controls, Inc.

Rockwell International lorp.

Rockwood Systems Corp.

Sigmon Corp.

Sill rer Bros., Inc.

TAPCO International, Inc.

IK. Valve \& Manufacturing, Inc.

Valtek, Inc.

Walworth Co.

Westinghouse Electro-Mech.

Division

Willis Di1 Tool Co.
AiResearch Manufacturing Co.

Anderson, Greenwood \& Co.

Bingham-Willamette Co.

Carborundum

Controlmatics Division, Litton

FMC Corp.

Honeywell, Inc.

B.uystrane. Valye

Luckheed Palo Alto Jaboratory

RP\&C Valve, Inc.

Rockwond systems Curp.

TXT/Division Vapor Corp. Yaiway Corp. 
Table 2. Valve availability for "most stringent" service applications

(Code: $A=$ available in sizes as requested in questionnaire; $X^{\prime \prime}=$ largest size available; $N=$ see note in last column)

\begin{tabular}{|c|c|c|c|c|c|c|c|c|c|c|c|c|c|c|c|c|c|c|}
\hline \multirow{2}{*}{$\begin{array}{l}\text { Service } \\
\text { Manufacturer } \\
\begin{array}{l}\text { Designation } \\
\text { pressure, } \\
\text { Temperig }\end{array} \\
\text { Temature, }{ }^{\circ} \mathrm{F}\end{array}$} & \multicolumn{3}{|c|}{ Lock hopper } & \multicolumn{4}{|c|}{ Slurry feed } & \multicolumn{3}{|c|}{ Slag letdown } & \multirow{2}{*}{ 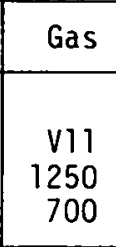 } & \multirow{2}{*}{$\begin{array}{r}\text { Steam } \\
12 \\
1250 \\
600 \\
\end{array}$} & \multirow{2}{*}{$\begin{array}{c}0_{2} \\
\begin{array}{c}13 \\
1300 \\
300\end{array} \\
\end{array}$} & \multicolumn{2}{|c|}{ Flow interrupt } & \multirow{2}{*}{$\begin{array}{l}\text { Equipment } \\
\text { Isolate } \\
\text { V20-24 } \\
620-260 \\
660-17000 \\
660-1700\end{array}$} & \multirow[b]{2}{*}{ Limiting factors } & \multirow[b]{2}{*}{ Notes } \\
\hline & $\begin{array}{l}v 1 \\
600 \\
660\end{array}$ & $\begin{array}{r}122 \\
1000 \\
660 \\
\end{array}$ & $\begin{array}{r}163 \\
1600 \\
660 \\
\end{array}$ & $\begin{array}{r}V 4 \\
1250 \\
660 \\
\end{array}$ & $\begin{array}{r}15 \\
1600 \\
660 \\
\end{array}$ & $\begin{array}{r}V 6 \\
4300 \\
625 \\
\end{array}$ & $\begin{array}{r}v 7 \\
1250 \\
700\end{array}$ & $\begin{array}{r}188 \\
7250 \\
700\end{array}$ & $\begin{array}{r}v 9 \\
1250 \\
1250\end{array}$ & $\begin{array}{r}1100 \\
1150 \\
600 \\
\end{array}$ & & & & $\begin{array}{l}\text { Coal } \\
v 14-16 \\
600-1000 \\
660\end{array}$ & $\begin{array}{c}5199 \\
v 17-19 \\
1150-1250 \\
660-1200\end{array}$ & & & \\
\hline $\begin{array}{l}\text { ACF Industries, W-K-M valve Division } \\
\text { Anchorloarring Valve Co. } \\
\text { Andco Industries } \\
\end{array}$ & $\begin{array}{l}A \\
\text { A } \\
\text { N }\end{array}$ & $\begin{array}{l}A \\
\text { A } \\
N\end{array}$ & $\begin{array}{l}A \\
\text { A } \\
\text { N }\end{array}$ & $\begin{array}{l}N \\
A \\
N\end{array}$ & $\begin{array}{l}N \\
\text { A } \\
N\end{array}$ & $\begin{array}{l}\text { N } \\
\text { A } \\
\text { N }\end{array}$ & $\begin{array}{l}\mathrm{N} \\
\mathrm{A} \\
\mathrm{N}\end{array}$ & $\begin{array}{l}\text { A } \\
\text { N } \\
\end{array}$ & $\begin{array}{l}A \\
\text { A } \\
\text { N }\end{array}$ & $\begin{array}{l}A \\
\text { A } \\
\text { N }\end{array}$ & $\begin{array}{l}A \\
\text { N } \\
\end{array}$ & $\begin{array}{l}\mathrm{A} \\
\mathrm{N}\end{array}$ & A & $\mathrm{N}$ & $\mathrm{N}$ & $\mathrm{N}$ & $\begin{array}{l}\text { Commercial incentives } \\
\text { Castings }\end{array}$ & $\begin{array}{l}\text { Designs require adaptation, } 1 \text { to } 2 \text { years } \\
\text { Custom high-temperature valve manufacturer }\end{array}$ \\
\hline $\begin{array}{l}\text { Atwood \& Morrill co., Inc. } \\
\text { Blaw-Knox Equipment, Inc. } \\
\text { Cameron Iron works, Inc. } \\
\end{array}$ & $\begin{array}{l}N \\
6 "\end{array}$ & $\begin{array}{l}N \\
6 "\end{array}$ & $\begin{array}{l}\text { N } \\
{ }^{\prime \prime}\end{array}$ & $\begin{array}{l}\text { N } \\
6 "\end{array}$ & $\begin{array}{l}N \\
6^{\prime \prime} \\
\end{array}$ & $\begin{array}{l}N \\
6 " \\
\end{array}$ & $\begin{array}{l}\mathrm{N} \\
{ }^{\prime \prime} \\
\end{array}$ & $\begin{array}{l}N \\
6^{\prime \prime}\end{array}$ & $\mathrm{N}$ & $\begin{array}{l}N \\
6^{\prime \prime}\end{array}$ & A & $\begin{array}{l}\text { A } \\
6 " 1 \\
\end{array}$ & $\begin{array}{l}\text { A } \\
\text { A }\end{array}$ & $\stackrel{N}{A}$ & $\stackrel{N}{A}$ & A & $\begin{array}{l}\text { Materials } \\
\text { High-temperature teśsting facility }\end{array}$ & $\begin{array}{l}\text { Ball valve under development } \\
\text { Custom designs } \\
\text { Development capability for larger sizes }\end{array}$ \\
\hline $\begin{array}{l}\text { Clow Corp., Engineering Products Div. } \\
\text { Consolidated Controls Corp. } \\
\text { Crane Co. }\end{array}$ & $\begin{array}{l}N \\
4^{\prime \prime} \\
A\end{array}$ & $\begin{array}{l}\mathrm{N} \\
4^{\prime \prime} \\
\mathrm{A}\end{array}$ & A & $\begin{array}{l}N \\
4 \\
A\end{array}$ & $\begin{array}{l}N \\
8^{\prime \prime} \\
A\end{array}$ & $\begin{array}{l}\mathrm{N} \\
\mathrm{A}\end{array}$ & $\begin{array}{l}N \\
6^{\prime \prime} \\
A\end{array}$ & $\begin{array}{l}N \\
6^{\prime \prime} \\
A\end{array}$ & $\begin{array}{l}N \\
6^{\prime \prime} \\
A\end{array}$ & $\begin{array}{l}N \\
6 " 1 \\
A\end{array}$ & A & $\begin{array}{c}A \\
10^{\prime \prime} \\
\end{array}$ & A & N & $\mathrm{N}$ & N. & Facility, manpower & $\begin{array}{l}\text { Potential designs } \\
\text { Larger sizes under development } \\
\text { particulate testing required }\end{array}$ \\
\hline $\begin{array}{l}\text { DeZurik, Unit of General signial } \\
\text { Oresser Industrial Valve \& Inst. Div. } \\
\text { Environmental Elements Corp. }\end{array}$ & A & $\mathrm{N}$ & $\mathrm{N}$ & N & $\mathrm{N}$ & & N & N & N & N & $\mathrm{N}$ & $\stackrel{N}{A}$ & N & & & $\mathrm{N}$ & $\begin{array}{c}\text { Commercial incentives } \\
1\end{array}$ & $\begin{array}{l}\text { Development capability, } 3 \text { to } 6 \text { years } \\
\text { Custom design as required }\end{array}$ \\
\hline $\begin{array}{l}\text { Everlasting valve co. } \\
\text { Fabri-valve } \\
\text { Fairchild Stratos }\end{array}$ & $\begin{array}{l}12 " 1 " \\
14 " \\
\mathrm{~N}\end{array}$ & $\begin{array}{c}N \\
10^{n} \\
N \\
\end{array}$ & ${ }^{\mathrm{N}}$ & ${ }^{\mathrm{N}}$ & $\mathrm{n}^{\mathrm{n}}$ & $\begin{array}{l}\mathrm{N} \\
\mathrm{N}\end{array}$ & $\begin{array}{l}\mathrm{N} \\
\mathrm{N}\end{array}$ & ${ }^{\mathrm{N}}$ & $\mathrm{n}^{\mathrm{N}}$ & $\begin{array}{c}n \\
n \\
101 \\
N \\
\end{array}$ & $\mathrm{~N}$ & N & $\mathrm{N}$ & & & & Materials, manpower: & $\begin{array}{l}\text { Design engineering required for higher pressure } \\
\text { Design engineering required for larger sizes } \\
\text { Custom designs, to } 12 \text { in. }\end{array}$ \\
\hline $\begin{array}{l}\text { Fetterolf Corp. } \\
\text { Fisher Controls co. } \\
\text { Fox Valve Development co. }\end{array}$ & $\begin{array}{l}\text { A } \\
8^{\prime \prime}\end{array}$ & $\begin{array}{l}\text { A } \\
8^{\prime \prime}\end{array}$ & $\begin{array}{l}\text { A } \\
8 "\end{array}$ & $\begin{array}{l}\text { A } \\
8^{\prime \prime}\end{array}$ & $\begin{array}{l}\text { A } \\
8^{\prime \prime}\end{array}$ & $\begin{array}{l}\text { A } \\
8^{\prime \prime}\end{array}$ & $\begin{array}{l}\text { A } \\
8^{\prime \prime}\end{array}$ & $\begin{array}{l}\text { A } \\
8 "\end{array}$ & A & $\begin{array}{l}\text { A } \\
8 "\end{array}$ & $\begin{array}{c}A \\
16^{\prime \prime} \\
8 "\end{array}$ & $\begin{array}{l}\text { A } \\
\text { A } \\
8 "\end{array}$ & $\begin{array}{l}A \\
A \\
A\end{array}$ & & & & Materials & $\begin{array}{l}\text { Custom designs } \\
\text { Custom designs }\end{array}$ \\
\hline $\begin{array}{l}\text { Gemco, The General Machine Co. } \\
\text { Hills s-McCanna Co. } \\
\text { Honeywell, Inc. }\end{array}$ & $\begin{array}{c}A \\
10 " \\
N\end{array}$ & $\begin{array}{l}A \\
8^{\prime \prime} \\
N\end{array}$ & $\begin{array}{l}\text { A } \\
\text { 8n } \\
N\end{array}$ & $\begin{array}{l}\mathrm{A} \\
\mathrm{g}^{\prime \prime} \\
\mathrm{N} \\
\end{array}$ & $\begin{array}{l}\text { A } \\
\mathrm{B}^{\prime \prime} \\
N\end{array}$ & $\begin{array}{l}\mathrm{A} \\
\mathrm{N}\end{array}$ & $\begin{array}{l}\mathrm{A} \\
\mathrm{B}^{\prime \prime} \\
N\end{array}$ & $\begin{array}{l}\mathrm{A} \\
\mathrm{B}^{\prime \prime} \\
\mathrm{N}\end{array}$ & $\begin{array}{l}\mathrm{A} \\
\mathrm{N}\end{array}$ & $\begin{array}{l}\text { A } \\
\text { 8n } \\
\text { N }\end{array}$ & $\begin{array}{r}8^{\prime \prime} \\
12^{\prime \prime}\end{array}$ & $\begin{array}{l}8^{\prime \prime} \\
A\end{array}$ & $\stackrel{A}{A}$ & A & A & & $\begin{array}{l}\text { Materials } \\
\text { Materials }\end{array}$ & $\begin{array}{l}\text { Design engineering required for high pressure } \\
\text { Development required for larger sizes, } 1 \text { to } 1-1 / 2 \text { years } \\
\text { Development capability, } 1 \text { to } 4 \text { years }\end{array}$ \\
\hline $\begin{array}{l}\text { Kamyr valves, Inc. } \\
\text { kieley and Mueller, Inc. } \\
\text { Powell, Wm., Co., The }\end{array}$ & & $\underset{A}{A}$ & $\begin{array}{l}A \\
6 " \\
A\end{array}$ & $\begin{array}{l}A \\
\text { A" } \\
A\end{array}$ & $\begin{array}{l}A \\
6^{\prime \prime} \\
A\end{array}$ & $\begin{array}{l}\text { 6" } \\
\text { A }\end{array}$ & $\begin{array}{l}A \\
b^{\prime \prime} \\
A\end{array}$ & $\begin{array}{l}A \\
b^{\prime \prime} \\
A\end{array}$ & A & $\begin{array}{l}A \\
6^{\prime \prime} \\
A\end{array}$ & A & $\begin{array}{l}\text { A } \\
6^{\prime \prime} \\
A\end{array}$ & $\begin{array}{l}A \\
A \\
A\end{array}$ & & & & $\begin{array}{l}\text { Materials } \\
\text { Materials }\end{array}$ & $\begin{array}{l}\text { Over } 16 " \text { requires finished ball import } \\
\text { Development capability for larger sizes, } 9 \text { months }\end{array}$ \\
\hline $\begin{array}{l}\text { RKL Controls, Inc. } \\
\text { Rockwell International Corp. } \\
\text { Rockwood Systems Corp. }\end{array}$ & $\begin{array}{l}6 " \\
6 "\end{array}$ & $\begin{array}{l}6^{\prime \prime} \\
6 "\end{array}$ & $\begin{array}{l}4^{\prime \prime} \\
6 "\end{array}$ & $\begin{array}{l}4 " 1 \\
6 "\end{array}$ & $\begin{array}{l}4 " 1 \\
6 "\end{array}$ & $4^{\prime \prime}$ & 6" & 6" & & $\begin{array}{l}4 " 1 " \\
6 "\end{array}$ & $\begin{aligned} & 6 " 1 \\
& 12 "\end{aligned}$ & $\begin{array}{l}\text { 6" } \\
\text { A } \\
\text { A }\end{array}$ & $\begin{array}{l}6 " \\
\text { A }\end{array}$ & & & & Datterns & $\begin{array}{l}\text { Devel opment capability for larger sizes, } 1 \text { to } 2 \text { years } \\
\text { Prefer development for larger sizes, } 1-1 / 2 \text { years }\end{array}$ \\
\hline $\begin{array}{l}\text { Sigmon Corp. } \\
\text { Sulzer Bros., Inc. } \\
\text { TAPCO International, Inc. }\end{array}$ & $\begin{array}{l}A \\
A \\
A\end{array}$ & $\begin{array}{l}A \\
A \\
A\end{array}$ & $\begin{array}{l}A \\
A \\
A\end{array}$ & $\begin{array}{l}A \\
A \\
A\end{array}$ & $\begin{array}{l}A \\
A \\
A\end{array}$ & $\begin{array}{c}12 " \\
A \\
A\end{array}$ & $\begin{array}{l}A \\
A \\
A\end{array}$ & $\begin{array}{l}A \\
A \\
A\end{array}$ & $\begin{array}{l}A \\
A \\
A\end{array}$ & $\begin{array}{l}A \\
A \\
A\end{array}$ & $\begin{array}{l}A \\
\text { A } \\
A\end{array}$ & $\begin{array}{l}A \\
A \\
A\end{array}$ & $\begin{array}{l}A \\
A \\
A\end{array}$ & & & & $\begin{array}{l}\text { Materials, marnuwer: } \\
\text { Design }\end{array}$ & $\begin{array}{l}\text { Valve life unknown } \\
\text { Requires in-field deve lopment, } 1 \text { year }\end{array}$ \\
\hline $\begin{array}{l}\text { TK Valve \& Manufacturing, Inc. } \\
\text { Val tek, Inc. } \\
\text { walworth Co. }\end{array}$ & $\begin{array}{l}A \\
A \\
A\end{array}$ & $\begin{array}{l}A \\
\text { A } \\
\text { A }\end{array}$ & $\begin{array}{l}\text { A } \\
\text { A } \\
\text { A }\end{array}$ & $\begin{array}{l}A \\
A \\
A\end{array}$ & $\begin{array}{l}A \\
A \\
A\end{array}$ & $\begin{array}{c}121 " \\
A \\
A\end{array}$ & $\begin{array}{l}A \\
A \\
A\end{array}$ & $\begin{array}{l}A \\
\text { A } \\
N\end{array}$ & $\begin{array}{l}A \\
\text { A } \\
\text { N }\end{array}$ & $\begin{array}{l}A \\
A \\
A\end{array}$ & $\begin{array}{l}A \\
\text { A } \\
\text { A }\end{array}$ & $\begin{array}{l}A \\
A \\
A \\
\end{array}$ & $\begin{array}{l}A \\
\text { A } \\
A\end{array}$ & & & & $\begin{array}{l}\text { Foundry } \\
\text { Manpower, machinery }\end{array}$ & $\begin{array}{l}\text { Seal development required, } 1-1 / 2 \text { years } \\
\text { New designs in progress } \\
\text { New bal1 valve under development, } 1-1 / 2 \text { to } 2 \text { years } \\
\end{array}$ \\
\hline $\begin{array}{l}\text { West inghouse Electro-Mech Div. } \\
\text { Will is Oil Tool Co. }\end{array}$ & 6" & 6". & 6" & 6" & 6" & 6" & 6" & 6" & 6" & 6" & $\begin{array}{c}12 " \prime \\
6 "\end{array}$ & ${ }_{6}^{A \prime \prime}$ & 6" & & & & Design testing & Development capability for larger sizes \\
\hline
\end{tabular}


THIS PAGE

\section{WAS INTENTIONALLY LEFT BLANK}




\section{Slurry Feed Valves}

\begin{tabular}{|c|c|}
\hline V-number & $\begin{array}{c}\text { Pressure } \\
\text { (psi) }\end{array}$ \\
\hline V4 & 1250 \\
\hline V5 & 1600 \\
\hline V6 & 4300 \\
\hline V7 & 1250 \\
\hline
\end{tabular}

\begin{tabular}{ccc}
$\begin{array}{c}\text { Temperature } \\
\left({ }^{\circ} \mathrm{F}\right)\end{array}$ & $\begin{array}{c}\text { Sizes } \\
\text { (in.) }\end{array}$ \\
\hline 660 & & $6,12,24$ \\
660 & & $6,12,24$ \\
625 & & $6,12,24$ \\
700 & & $6,10,12$
\end{tabular}

The confidence of companies to manufacture valves for V4, V5, V6, and V7 operating conditions is as high as it is for the conditions for types V1, V2, and. V3. Pressures of $4300 \mathrm{psi}$ (V6) and temperatures of $700^{\circ} \mathrm{F}$ (V7) reduce only slightly the number of manufacturers who offer suitable designs.

$\underline{\text { Slag-Char Letdown Valves }}$

\begin{tabular}{|c|c|c|c|}
\hline $\mathrm{V}$-number & $\begin{array}{c}\text { Pressure } \\
\text { (psi) } \\
\end{array}$ & $\begin{array}{c}\begin{array}{c}\text { Temperature } \\
\left({ }^{\circ} \mathrm{F}\right)\end{array} \\
\end{array}$ & $\begin{array}{l}\text { Sizes } \\
\text { (in.) } \\
\end{array}$ \\
\hline v8 & 1250 & 700 & $6,10,12$ \\
\hline V9 & 1250 & 1200 & 6 \\
\hline $\mathrm{V} 10$ & 1150 & 600 & $6,10,12$ \\
\hline
\end{tabular}

The confidence of companies to manufacture valves for V8, V9, and . V10 operating conditions is as high as for types V1. through V7. "The $700^{\circ} \mathrm{F}$ (V8) and $1200^{\circ} \mathrm{F}$ (V9) reduce only slightly the manufacturers' confidence in their valve designs.

Gas, Steam, and Oxygen Valves

\begin{tabular}{|c|c|c|c|}
\hline V-number & $\begin{array}{c}\text { Pressure } \\
\text { (psia) }\end{array}$ & $\begin{array}{c}\text { Temperature } \\
\left({ }^{\circ} \mathrm{F}\right) \\
\end{array}$ & $\begin{array}{l}\text { Sizes } \\
\text { (in.) }\end{array}$ \\
\hline V11 & $1250^{\circ}$ & 700 & 12,24 \\
\hline V12 & 1250 & 600 & $6,10,12$ \\
\hline V13 & 1300 & 300 & 8 \\
\hline
\end{tabular}

Many manufacturers have the capability to manufacture and furnish valves for V11, V12, and V13 operating conditions, which are not unusual 
in the petrochemical industry. If the process flow stream composition is fairly free of abrasives and contaminants, the valves for these applications will be readily available.

Flow Interruption and Equipment Isolation Valves

\begin{tabular}{|c|c|c|c|}
\hline V-number & $\begin{array}{l}\text { Pressure } \\
\text { (psi) } \\
\end{array}$ & $\begin{array}{c}\text { Temperature } \\
\left({ }^{\circ} \mathrm{F}\right)\end{array}$ & $\begin{array}{l}\text { Sizes } \\
\text { (in.) }\end{array}$ \\
\hline$V-14$ & 600 & 660 & $6,12,24$ \\
\hline$V-15$ & 1000 & 660 & $6,12,24$ \\
\hline$V-16$ & 1600 & 660 & $6,12,24$ \\
\hline$V-17$ & 1250 & 700 & $6,10,12$ \\
\hline$v-18$ & 1250 & 1200 & 6 \\
\hline$V-19$ & 1150 & 660 & $6,10,12$ \\
\hline$v-20$ & 600 & 660 & 54,60 \\
\hline$V-21$ & 1000 & 660 & 54,60 \\
\hline$V-22$ & 1250 & 1700 & 54,60 \\
\hline$V-23$ & 1600 & 660 & $54 ; 60$ \\
\hline$V-24$ & 4200 & 850 & 36,48 \\
\hline
\end{tabular}

Valves of the types most likely to be applied for the V-14 through V-24 operating conditions would be blast, slide, and knife-edge types, which are, in general, custom-built designs. Design staffs and fabricating facilities are available to provide these types of valves for coal conversiull planls. 


\section{VALVE ACTUATOR SURVEY}

\section{5:1 Method}

The valve, complete with actuator, is generally purchased from a valve manufacturer. As such, valve-actuator manufacturers sell their products to the valve manufacturer directly rather than separately to a valve user. Although some valve manufacturers produce actuators for their own valve line, this is not the common practice for the majority of coal conversion valves used in the most stringent service applications.

In coal conversion plant applications, the valve with actuator would probably be located in either an outdoor location or a shed-type enclosure and might be subjected to explosive vapors or explosive dust. As such, the mechanism would be sealed and perhaps purged with an inert gas to negate both dirt intrusion and ignition sources.

To ascertain the capability of the valve-actuator industry to supply actuators for the most stringent applications in a coal conversion plant, a questionnaire was sent to 49 valve-actuator manufacturers. They were requested to furnish information on their facilities, standard products, developmental and testing capabilities, and long-range plans for product development (see Appendix E).

\subsection{Response to Survey}

Responses to the survey (Appendix B) include most of the major actuator manufacturers. In general, no responses were received from companies that do not manufacture the large actuators important to coal conversion plants.

Table 3 lists the companies who stated that they manufactured actuators suitable for critical application in coal conversion plants. Included in the listing are names of manufacturers who also noted applicable actuator manufacturing capability in their response to the valve questionnaire. Some valve companies who manufacture actuators possibly are not included because the valve questionnaire inadvertently did not request information on actuators. 
Table 3. Valve actuator survey summary

(Companies who manufacture actuators suitable for severe environmental

applications in coal conversion plants)

Anchor/Darling Valve Co.

Andco Actuator Products, Inc.

Arral Industries, Inc.

Automated Valve \& Control

Becker Precision Equipment, Inc.

Bellows International

Beswick Engineering

Bettis Corporation

EIM Company, Inc.

Limitorque Corporation

Newbrook Machine Corp.

Ralu Inlelihalluhal, Inl.

Raymond Control Systems, Division Vapor Corp.

Rotork Controls, Inc.

Sulzer Bros., Inc.

\subsection{Actuator Survey Results}

Valve-actuator manufacturers have the capability to produce in quantity the types of actuators that would be required by the coal conversion industry. Manufacturers have standard actuator designs capable of actuating valves of the largest size and at the highest pressures required in coal conversion plants. Available are designs that use either pneumatic, hydraulic, or electromechanical force and produce either rotary or linear motion. Manufacturers also provide complete preengineered actuator control assemblies with remote position indication. Facilities are also available for design, development, manufacture, and testing of new concepts as required. 


\section{ANALYSIS OF SURVEY RESULTS}

\subsection{Background}

The United States has between 500 and 600 valve manufacturers who produce industrial valves applicable to coal conversion. The valve industry is large, divergent, competitive, and responsive to the economics of industry. Manufacturers vary from large integrated companies to the small machine-shop assembly companies who subcontract their major meta1forming operations.

In general, the smaller manufacturers are more available to produce a custom valve for a particular application than are large companies with well-established commercial markets. However, the economic potential of a new large industrial market, such as the coal conversion industry, is an incentive for large companies to develop new product lines.

\subsection{Technology}

With the advent of the nuclear industry and its demanding requirements for pressure integrity, operational assurance, and leak-tightness, a program of fundamental research was instigated, which included both analytical techniques and testing. As such, the major manufacturers have greatly improved their plant capabilities, testing facilities, and technical personnel capabilities. The results of this nuclear-instigated program have found their way into the-general industrial markets; consequently the quality of valves available for the future coal conversion industry has improved dramatically in the past few years. Plant capacity is larger, precision machines are more available, testing equipment is available, and - most important - the industry has improved its technical capability in design and metallurgy.

Most valves that have been and will be used in coal conversion process applications are modified staldard water-o1l-gas commercial industrial valves. Manufacturers of these types of valves have recommended combinations of materials, disk assemblies, guides, and packing arrangements applicable to various process requirements. Each combination and modification responds under service differently, depending on the material, temperature, pressure, valve orientation, applied loadings to the valve, induced 
vibration in the valve assemblage, and speed of operation. These effects in conjunction with modifications required for coal conversion operating conditions and installation restraints can be determined only by inservice experience; however, individual effects could be determined by establishing a controlled variable testing facility.

\subsection{Valve Specification}

Valves used in general industrial applications are required by law to meet applicable safety piping codes. For the coal conversion industry, this will probably mean conformance with the American National Standard Code for Pressure Piping, Chemical Plant and Petroleum Refinery Piping, ANSI B31.3 (ref. 9). This code, by reference, requires the valves either to conform with ANSI B16.5 (ref. 10), ANSI B16.34 (ref. 11), or API 600 (ref. 12) or to be in accordance with design rules established in the text of the code.

These codes and standards address only the structural integrity of the valve, not its operability. Factors ${ }^{3}$ important to the full identification of valve designs and materials for use in the manufacture of valves are:

Design pressure and temperature

- Operating pressure and temperature, normal and abnormal

- Proces's chemistry, normal and abnormal

- Valve application

- Valve orientation

- Valve use frequéncy

- Valve leakage acceptability

- Flow capac1ty

- Significant thermal transienes

- Dynamic loadings

- Structural support loading

- Environmental conditions

- Material requirements

- Special provisions for maintenance 
The limited information furnished to the valve manufacturers in this survey included only normal operating pressure and temperature, valve application, and normal process chemistry. This descriptive information is inadequate to identify fully a satisfactory valve design.

\subsection{Limiting Factors}

The factors identified most frequently by valve manufacturers as limiting their capability to manufacture valves for the coal conversion industry were materials, design, and testing facilities (see Table 2).

\section{Materials}

Only a few manufacturers of large-size high-temperature, high-pressure valves have facilities with which to cast or forge the valve body. This valve part is procured by. contract individually from various material suppliers. Procurement time and production quantities depend on the material suppliers.

Several years ago a major problem in procuring valves was the withdrawal from production by many of the suppliers rather than retrofitting their facilities to conform with the standards of the Occupational Safety and Health Administration (OSHA). However, this problem has been solved by the valve manufacturers, who have developed alternative sources of materials:

Changes to a valve body configuration, larger sizes, or thicker walls require modifications of forging dies and casting patterns, which creates time-consuming and expensive constraints to the development of new valve types and limits production quantities.

\section{Design}

Most manufacturers are limited by the number of design personnel they are willing to commit to preparing a revised valve design. Increases in both valve size and pressure-temperature ratings are major undertakings, which require analysis, drawings, work procedures, scheduling, new holding fixtures, cleaning facilities, material subcontracts, etc. For most valve manufacturers, especially for those who manufacture a nationally 
advertised type of valves, there must be a strong commercial incentive for adoption of such a prögram.

Testing Facilities

In general, most valve manufacturers are equipped for very limited testing. Pressure (structural) and leakage testing is standard. Material examination using $\mathrm{x}$-ray, magnetic-particle, and liqu1d-penetrant techniques is available to all manufacturers, but operational and temperature tests are nor. Reclfculaliug loops for testing valvec with simulated process fluids are so limited as to be almost unavailable in any manufacturing facility. It currently appears that valve operational testing can be accomplished only in actual service aflet the oor conversion plant is constructed and in operation or in DOE-sponsored valve test facilities such as the Morgantown Energy Research Center Facility (see Ser.t. 4.3).

\subsection{Impact}

The health of the valve industry currently reflects the general industrial economic conditions in the United States. Industrial construction is very low compared to the 1973 era, and excess capacity is readily available in major valve manufacturing plants. The construction of several billion dollars of commercial coal conversion plants would nut drastically alter this situation. The U.S. Department of Commerce estimated that the dollar volume of sales of industrial-type valves was $\$ 1.7$ billion per year in 1975. Üsing an estimating rule of thumb that valves account for $3 \%$ of the capital cost of an industrial-type facility somewhat comparable to a coal conversion plant, a billion-dollar facillty would use about $\$ 50$ million for valves. During a 3-year construction period, each coal conversion plant would use about $1 \%$ of the industrial valve annual sales volume.

\subsection{Potential Problem Areas}

Understandably, no one can foresee the impact of a coal conversion industry on the valve manufacturing industry. The following situations, 
however, could change in the future and could therefore create availability problems.

\section{Industrial Economic Improvement}

If the coal conversion industry construction period should coincide with other major industrial construction programs or with a major expansion in nuclear energy, the surplus valve manufacturing capacity would diminish rapidly.

\section{Alloy Availability}

Materials such as nickel, cobalt, chromium, and molybdenum that are needed for high-temperature valves are a world-wide problem, with economic, social, and political implications. If these materials should become scarce, they would probably be limited to "high-technology" applications, and substitutes would have to be developed for normal commercial use.

\subsection{Availability Summary}

$\underline{\text { Valves }}$

The questionnaire responses in Appendix A denote the size and manufacturing capability of 77 of the 500 or more industrial valve manufacturers in the United States. Included in the 77 are most of the largest manufacturers; in dollar volume of sales, these 77 manufacturers account for over $90 \%$ of the industrial valve sales in this country. Table 2 lists availability responses from 35 of these 77 companies, who indicated that they produce valves applicable to the 24 operating conditions judged to be the "most stringent" service applications for shutoff type valves in future coal conversion plants.

Although Table 2 tends to indicate "availability" from numerous valve manufacturers, the term availability is ambiguous. As can be discerned from the Notes coluim, availabll1ty is readiness and capability to manufacture custom valves or a particular (patent) design, which may or imay nul have a prolonged sarisfactorily life.

Results of the survey show that the valve Industry has the capability to manufacture valves of the size and to the prcssurc-temperature 
conditions that will be required for the coal conversion industry. However, to ascertain the continuing functional ability of valves, especially with flow streams containing particulates, development and testing will be required to optimize the available valve designs.

\section{Actuators}

The questionnaire responses in Appendix B denote the size and manufacturing capability of 18 valve-actuator manufacturers. The valveactuator industry is apparently capable of supplying actuators of the size and for applications that will be required in future coal conversion plants. 


\section{RECOMMENDATIONS}

The response to this survey indicates that the valve industry is capable of manufacturing in quantity valves of the size and for the pressure-temperature conditions that will be required for the coal conversion industry; however, the valve configuration and the optimization of material combinations for specific application is indeterminate. To adequately prepare the valve industry to supply valves for the coal conversion industry, finite functional valve specifications should be prepared for critical service applications. To accomplish this task, the following future studies should be undertaken:

1. define the specific valve application and function for critical service applications in specific coal conversion processes, including pressure letdown valves;

2. determine the potential commercial market for valves specific to the coal conversion industry;

3. disseminate information on coal conversion valve experiences to avoid repetition of misapplication of valve designs and to contribute to advanced configuration-material valve designs; and

4. analyze successful valve applications in similar industrial applications to stimulate transfer of valve technology. 
THIS PAGE

\section{WAS INTENTIONALLY LEFT BLANK}




\section{REFERENCES}

1. J. P. Meyer and M. S. Edwards, Survey of Industrial Coal Conversion Equipment Capabilities: Assessment of the State of the Art of High Temperature-High Pressure Gas Purification, ORNL/TM-6072 (1978).

2. W. R. Gambill and W. R. Reed, Survey of Industrial Coal Conversion Equipment Capabilities: Heat Recovery and Utilization, ORNL/TM-6073 (1978).

3. W. R. Williams et a1., Survey of Industrial Coal Conversion Equipment Capabilities: Rotating Components, ORNL/TM-6074 (1978).

4. J. F. Garner, Survey of Valve Industry, 6-inch Valves for Coal Conversion Processes, Morgantown Energy Research Center, Energy Research and Development Administration, Morgantown, W. Va. (February 1977).

5. The Valve Manufacturers Association, Membership List, Drawer II, McLean, Va. 22101.

6. American Chemical Society, "1977-78 Equipment Buyer's Guide Issue," Chem. Eng. 84(15): pt. 2 (July 18, 1977).

7. "Products Directory," Heat. Piping Air. Cond. 48(6) (June 1976).

8. Thomas Publishing Company, Thomas Register of American Manufacturers and Thomas Register Catalog File, 1977.

9. The American Society of Mechanical Engineers, ANSI Standard Code for Pressure Piping, Chemical Plant and Petroleum Refinery Piping, ANSI B31. 3 - 1976, New York, 1976.

10. The Allierican Society of Mechanical Engineers, Steel Pipe F'langes and Flanged Fittings, ANSI B16.5 - 1973, New York, 1973.

11. The American Society of Mechanical Engineers, Steel Butt-Welding End Valves, ANSI B16.34 - 1973, New York, 1973. 
12. American Petroleum Institute, Steel Gate Valves - Flanged or ButtWelding Ends, API $600-1973$, Division of Refining, Washington, D.C., 1973.

13. The American Society of Mechanical Engineers, Self Operated and Power Operated Safety-Related Valves, Functional Specification Standard, ANSI N278.1 - 1975, New York, 1975. 
THIS PAGE

\section{WAS INTENTIONALLY LEFT BLANK}


Appendix A

CAPABILITY RESPONSES OF VALVE MANUFACTURERS 
Appendix A

0

CAPABILITY RESPONSES OF VALVE MANUFACTURERS

Page

ACF Industries, Inc. . . . . . . . . . . . . . . . 41

Abex Corporation . . . . . . . . . . . . . . . . 42

AiResearch Mfg. Co. . . . . . . . . . . . . . . 43

AMETEK/Schutte \& Koerting Div. . . . . . . . . . . . . . . . . . . 44

Anchor/Darling Valve Co. . . . . . . . . . . . . . . . 45

Andco Actuator Products, Inc. . . . . . . . . . . . 46

Anderson, Greenwood \& Co. . . . . . . . . . . . . . . 47

Atwood \& Morrill Co., Inc. . . . . . . . . . . . . . 48

Automatic Switch Company . . . . . . . . . . . . . . 49

Bingham-Willamette Company . . . . . . . . . . . . . . 50

Blaw-Knox Equipment, Inc. . . . . . . . . . . . . . . 51

C-E INVALCO . . . . . . . . . . . . . . . . . . . 52

Calmec . . . . . . . . . . . . . . . . . . . 53

Cameron Iron Works, Inc. . . . . . . . . . . . . . . 54

THE CARBORUNUUM COMPANY . . . . . . . . . . . . . . . . . . . . 5

CIRCLE SEAL CONTROLS . . . . . . . . . . . . . . . . 56

Cleveland Armstrong Company . . . . . . . . . . . . . . 57

C1ow Corp., Engineered Products Div. . . . . . . . . . . 58

CODECAL Inc. . . . . . . . . . . . . . . . . . . . 59

Consolidated Controls Corp. . . . . . . . . . . . . . 60

Contromatics Vivision . . . . . . . . . . . . . . 61

Crane Co. . . ...................... . . 62

Crosby Valve \& Gage Company . . . . . . . . . . . . . 63 
0

DALly ENGINEERING-VALVE COMPANY . . . . . . . . . . . . . . 64

DeZURIK, A Unit of General Signal . . . . . . . . . . . . 65

Dresser Industrial Valve \& Inst. Div. . . . . . . . . . . 66

Environmental Elements Corporation . . . . . . . . . . . 67

Everlasting Valve Company . . . . . . . . . . . . . 68

FMC Corporation . . . . . . . . . . . . . . . . . . 69

Fabri-Valve . . . . . . . . . . . . . . . . 70

Fairchild Stratos Division . . . . . . . . . . . . . . . 71

Fetterolf Corporation . . . . . . . . . . . . . . . 72

Fisher Controls Company . . . . . . . . . . . . . . 73

Fox Valve Development Co., Inc. . . . . . . . . . . . . 74

Gas Machinery Division, Modern Equipment Co. . . . . . . . 75

Gemco, The General Machine Co. of N.J. . . . . . . . . . . 76

Gould Inc., Valve and Fittings Div. . . . . . . . . . . . 77

Halliburiun services . . . . . . . . . . . . . . . . 78

Henry Valve Co. . . . . . . . . . . . . . . . . . 79

Hills-McCanna Company . . . . . . . . . . . . . . 80

HONEYWELL, INC. . . . . . . . . . . . . . . . . . . . 81

KAMYR VALVES, INC. . . . . . . . . . . . . . . . . 82

Kerotest Manufacturing Corp. . . . . . . . . . . . . . 83

Keystone Valve Division, Keystone International, Inc. . . . . . . 84

Kieley and Mueller, Inc. . . . . . . . . . . . . . 85

LADISH CO. . . . . . . . . . . . . . . . . . . . 86

Lockheed Missiles \& Space Co., Inc., Palo Alto Research

Laboratory . . . . . . . . . . . . . . . . . 87

J. E. Lonergan Company . . . . . . . . . . . . . . . 88 
Lunkerheimer Company, The . . . . . . . . . . . . . 89

MCC MARPAC, A Unit of Mark Controls Corp. . . . . . . . . . . 90

PEABODY DORE' CORP. . . . . . . . . . . . . . . . . . . 91

Powell, Wm., Co., The ...... . . . . . . . . . . . 92

RKL Controls, Inc. . . . . . . . . . . . . . . . 93

Red Valve Co., Inc. . . . . . . . . . . . . . . . . 94

Rockwell International Corporation . . . . . . . . . . . . 95

Rockwood Systems Corporation . . . . . . . . . . . . . . 96

Royal Industries, Energy Products Division . . . . . . . . . 97

Shan-Rod, Inc. . . . . . . . . . . . . . . . . . 98

Sigmon Corporation . . . . . . . . . . . . . . . . . 99

Smith Valve Corporation . . . . . . . . . . . . . . 100

Specialty Valve \& Controls, Inc. . . . . . . . . . . . 101

Sperry Vickers . . . . . . . . . . . . . . . . . 102

Stockham Valves \& Fittings . . . . . . . . . . . . . 103

Sulzer Bros., Inc. . . . . . . . . . . . . . . . 104

TAPCO International, Inc. . . . . . . . . . . . . . 105

TK Valve \& Manufacturing, Inc. . . . . . . . . . . . 106

TXT/Division Vapor Corporation . . . . . . . . . . . . 107

Teledyne Farris Engineering . . . . . . . . . . . . . . 108

Tufline Div., Xomox ..................... 109

VALTEK, INCORPORATED . . . . . . . . . . . . . . . . . 110

WALWORTH Company . . . . . . . . . . . . . . . . . 111

Watts Regulator Company . . . . . . . . . . . . . 112

Westinghouse Electric Corporation, Electro-Mechanical

Division . . . . . . . . . . . . . . . . . . . 113 


\section{Page}

Willis 0 il Tool Co. . . . . . . . . . . . . . . . . 114 Worcester Controls Corporation . . . . . . . . . . . . 115 Yarway Corporation . . . . . . . . . . . . . . . . 116 Zidell Explorations, Inc. . . . . . . . . . . . . . . . 117 


\begin{tabular}{|c|c|c|c|}
\hline \multirow{2}{*}{$\begin{array}{l}\text { FIRM NAME/ADDRESS/PHONE } \\
\text { ACF Industries, Inc. } \\
\text { W-K-M Valve Division } \\
\text { P.0. Box } 2117 \\
\text { Houston, TX } 77001 \\
\text { (713) } 499-1511\end{array}$} & \multicolumn{2}{|c|}{$\begin{array}{l}\text { YEAR PRESENT FIRM ESTABLISHED } \\
1901 \text { - Formation of original } \\
\text { W-K-M Company. }\end{array}$} & $\begin{array}{l}\text { SURVEY DATE } \\
7 / 12 / 77\end{array}$ \\
\hline & \multicolumn{3}{|c|}{$\begin{array}{l}\text { CONTACTS: NAME/TTTTE/PHONE } \\
\text { W.E.Remp - Genérat } \\
\text { A.M. Wifliamson - Director - Eng \& Res. } \times 340 \\
\text { M.S. Kalsi-Manager - Res \& Dev - ext. } 515 \\
\end{array}$} \\
\hline \multicolumn{4}{|c|}{ FORMER FIRM NAME, IF ANY, AND YEAR ESTABLISHED } \\
\hline \multicolumn{4}{|l|}{ ACF Industries, Inc. } \\
\hline \multicolumn{4}{|c|}{\begin{tabular}{l|c|c} 
VALVE PLANT LOCATIONS & NUMBER OF EMPLOYEES & PLANT FLOOR SPACE \\
Houston, TX Richmond, TX & & 12 acres - Hous ton Plant \\
Shreveport, Louisiana & approx. 2500 & 6 acres - Richmond Plant \\
Scotland & &
\end{tabular}} \\
\hline \multicolumn{4}{|c|}{$\begin{array}{l}\text { BRIEF STATEMENT AS TO STANDARD VALVE PRODUCTS } \\
\text { Small ( } 1 "-6 ") \text { Gate Valves - "Pow-R-Seal" and 'Saf-T-Seal" type } \\
\text { Sma:l } 1(1 / 4 "-12 \text { ") Floating Bal Valves \& Trunnion Ball Valves } \\
\text { Cylindrical, Lubricated Plug Valves }\left(1 / 2^{\prime \prime}-12^{\prime \prime}\right) \\
\text { Large (14"-48") Trunnion Mounted Ball Valves } \\
\text { Large (6"-48") Gate Valves } \\
\text { Control Valves }\end{array}$} \\
\hline \multicolumn{4}{|c|}{$\begin{array}{l}\text { - Experimental Stress Analysis } \\
\text { - Bendirig Moment Tests to Simulate Pipe Loads } \\
\text { - High Temp Testing - Stem to } 600^{\circ} \mathrm{F}, \mathrm{N}_{2} \text { to } 1200^{\circ} \mathrm{F} \\
\text { - High Volume Flwo Simulation Blow-down Dhambers } \\
\text { - Cold Testing Down to }-75^{\circ} \mathrm{F} \\
\text { - Abrasion Testing with Sand Slurry } \\
\text { - Fire Testing }\end{array}$} \\
\hline \multicolumn{4}{|c|}{$\begin{array}{l}\text { REMARKS: COMMENTS OF FUTURE PRODUCT LINES THAT MAY BE AVATLABLE BY 1982?, BY 1987? } \\
1982 \text { - High Temp Ball Valves - Large Sizes 14" \& up } \\
\text { Good upto } 1200^{\circ} \mathrm{F}\end{array}$} \\
\hline \multicolumn{4}{|c|}{1987 - Through Conduit Valves for Higher Temperatures - upto $1800^{\circ} \mathrm{F}$} \\
\hline \multicolumn{4}{|c|}{$\begin{array}{l}\text { * LIST NAME AND ADDRESS AS YOU WOULD LIKE TO HAVE LISTED IN THE FINAL KEFORT } \\
\text { A. M. Williamson } \\
\text { Director - Engrg \& Research } \\
\text { ACF Industries, Inc. } \\
\text { W-K-M Valve Division } \\
\text { P.O. Box } 2117 \\
\text { Houston, TX } 77001\end{array}$} \\
\hline
\end{tabular}




\begin{tabular}{|l|l|c|}
\hline $\begin{array}{l}\text { FIRM NAME/ADDRESS/PHONE* } \\
\text { Abex Corporation } \\
\text { Engineered Products Division } \\
\text { Valley Road } \\
\begin{array}{l}\text { Mahwah, NJ 07430 } \\
(201) 529-3450\end{array}\end{array}$ & $\begin{array}{l}\text { YEAR PRESENT FIRM ESTABLISHED } \\
1902\end{array}$ & $\begin{array}{c}\text { SURVEY DATE } \\
8-16-77\end{array}$ \\
\cline { 2 - 3 } & $\begin{array}{l}\text { CONTACTS: NAME/TITLE/PHONE } \\
\text { R. Daniel Gladding, Manager, Marketing \& Plan- } \\
\text { ning/(201) 529-3450 }\end{array}$ \\
\hline
\end{tabular}

FORMER FIRM NAME, IF ANY, AND YEAR ESTABLISHED

American Brake Shoe Company (1902)

PARENT COMPANY

IC Industries

\begin{tabular}{|c|c|c|}
\hline $\begin{array}{l}\text { PLANT LOCATIONS Eng'd Prods' } \\
\text { Division } \\
\text { Elyria, OH Rochester \& } \\
\text { Mahway, NJ Medina, NY } \\
\text { Meadwilie. PA }\end{array}$ & $\begin{array}{l}\text { NUMBER OF EMPLOYEES } \\
\qquad 1,700\end{array}$ & PLANT FLOOR SPACE \\
\hline \multicolumn{3}{|c|}{ BRIEF STATEMENT AS TO ACTUATOR PRODUCTS } \\
\hline
\end{tabular}

BRIEF STATEMENT AS TO DEVELOPMENTAL AND TESTING CAPABILITIES

Abex has a strong background in alloy development, particularly in the heat, corrosion, and abrasion resistant areas. Creep-rupture, abrasion and corrosionerosion testing is available at the Research Center in Mahwah, NJ.

REMARKS: COMMENTS OF FUTURE PRODUCT LINES THAT MAY BE AVAILABLE BY 1982? BY 1987? We anticipate to continue work on alloys for better resistance to heat, corrosion, and abrasion.

* LIST NaMe AND ADDRESS AS YOU WOULD LIKE TO hAVE IT LISTED IN THE REPORT 


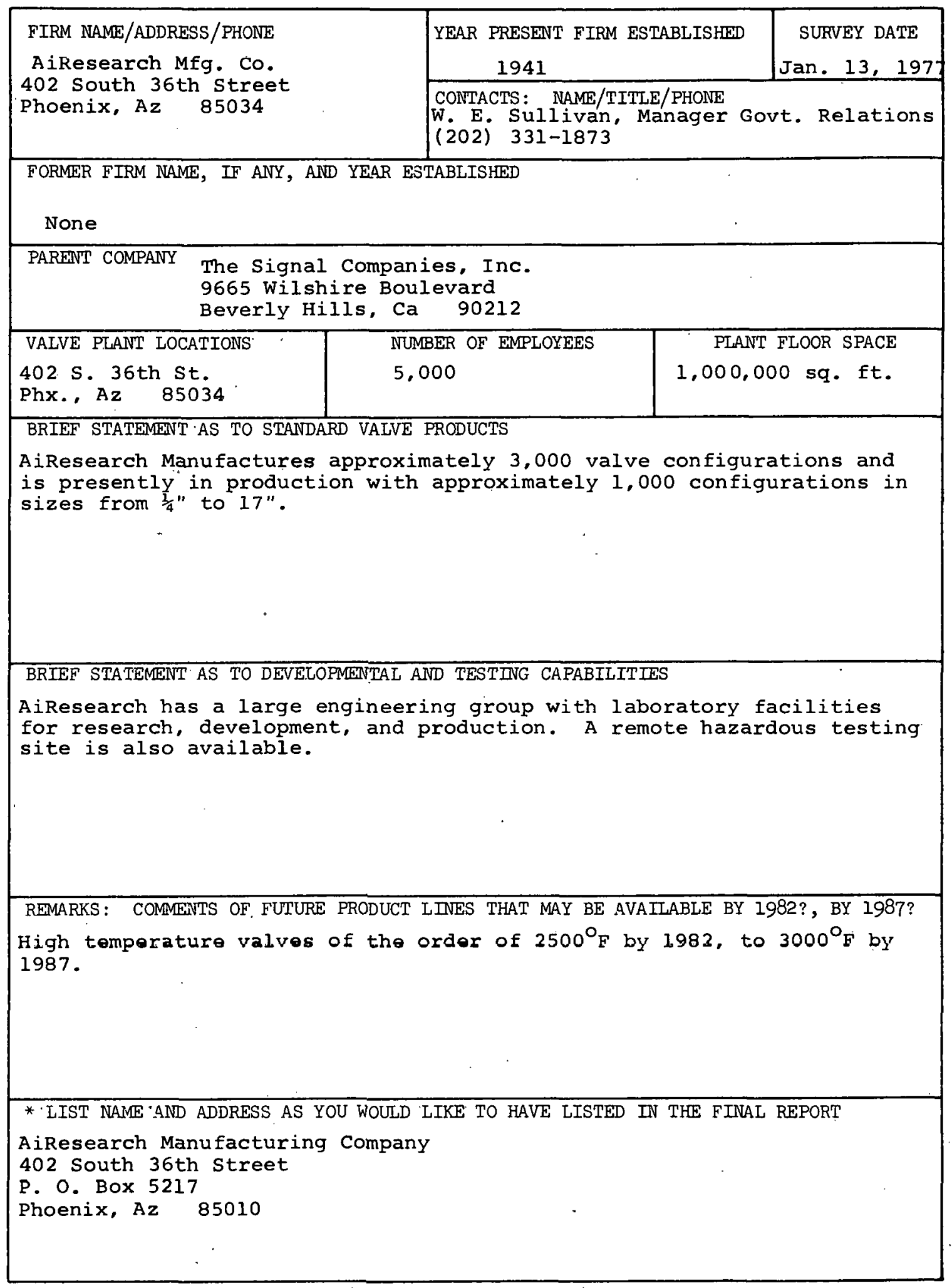




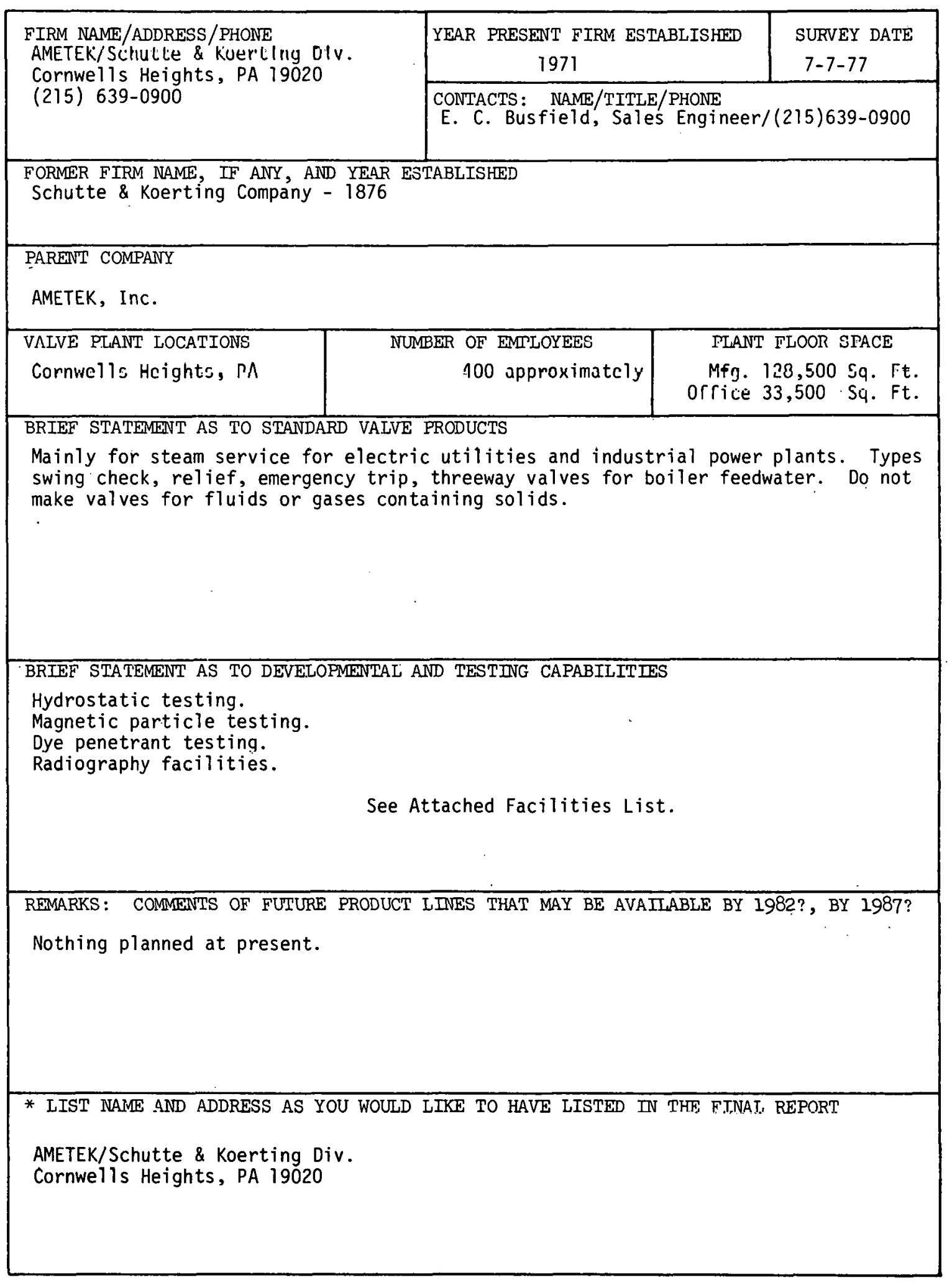




\begin{tabular}{|c|c|c|}
\hline \multirow{2}{*}{$\begin{array}{l}\text { FIRM NAME/ADDRESS/PHONE } \\
\text { Anchor/Darl ing Valve Co. } \\
\text { I Belmont Avenue, Suite } 320 \\
\text { Bala Cynwy, PA i9004 } \\
(215) 667-9090\end{array}$} & $\begin{array}{c}\text { YEAR PRESENT FIRM ESTABLISHED } \\
1968\end{array}$ & $\begin{array}{c}\text { SURVEY DATE } \\
6 / 20 / 77\end{array}$ \\
\hline & \multicolumn{2}{|c|}{$\begin{array}{l}\text { CONTACTS: NAME/TITLE/PHONE } \\
\text { R. E. Bergman, Proposal Mgr. (215) } 667-9090 \\
\text { R. E. Rinehart, Mgr. Marketing/Operations }\end{array}$} \\
\hline \multicolumn{3}{|c|}{$\begin{array}{l}\text { FORMER FIRM NAME, IF ANY, AND YEAR ESTABLISHED } \\
\text { Darling Valve \& Manufacturing Co. } 1888 \\
\text { Anchor Valve Co. } 1946\end{array}$} \\
\hline \multicolumn{3}{|l|}{$\begin{array}{l}\text { PARENT COMPANY } \\
\text { Anchor/Darling Industries } \\
\text { One Belmont Avenue, Suite } 406 \\
\text { Bala Cynwyd, PA } 19004\end{array}$} \\
\hline $\begin{array}{l}\text { VALVE PLANT LOCATIONS } \\
\text { Will i amsport, PA } \\
\text { Hayward, CA }\end{array}$ & \begin{tabular}{|l|r} 
SER OF EMPLOYEES & PLAI \\
231 & 90,0 \\
202 & 40,0
\end{tabular} & $\begin{array}{l}\text { FLOOR SPACE } \\
\text { Sq. Ft. } \\
\text { Sq. Ft. }\end{array}$ \\
\hline \multicolumn{3}{|c|}{$\begin{array}{l}\text { A/DV is a custom engineered valve manufacturer and has designed a large variety of } \\
\text { specialty valves for the nuclear and fossil power, petro chemical and marine in- } \\
\text { dustries. We normally supply gate (both flex wedge and docble disc), globe } \\
\text { (horizontal, Y-globe, angle and Y-angle), and check (swing, tilting disc, lift } \\
\text { check) valves in sizes } 21 / 2^{\prime \prime} \text { to } 54^{\prime \prime}, 150 \text { to } 4500 \text { lb. pressure ratings, in carbon } \\
\text { steel and a wide range of special alloys. }\end{array}$} \\
\hline \multicolumn{3}{|c|}{$\begin{array}{l}\text { BRIEF STATEMENT AS TO DEVELOPMENTAL AND TESTING CAPABILITIES } \\
\text { Both facilities have a large engineering staff under the direction of a chief } \\
\text { engineer and are capable of designing valves for most critical services. In } \\
\text { addition, our corporate staff includes a technical director and a design director } \\
\text { in charge of research and development. }\end{array}$} \\
\hline \multicolumn{3}{|c|}{$\begin{array}{l}\text { REMARKS: COMMENTS OF FUTURE PRODUCT LINES THAT MAY BE AVAILABLE BY } 1982 \text { ?, BY } 1987 \text { ? } \\
\text { A/DV is continuousily performing R\&D, investigating modifications to existing } \\
\text { designs, and performing prototype tests on new designs. We are currently involved } \\
\text { in work on a laminated metal seat top entry butterfly valve for high temperature } \\
\text { service. We are also investigating the feasibility of adapting our unique double } \\
\text { disc wedging mechanism for use in our conduit design gate valve. }\end{array}$} \\
\hline \multicolumn{3}{|c|}{ * LIST NAME AND ADDRESS AS YOU WOULD LIKE TO HAVE LISTED IN THE FINAL REPORT } \\
\hline
\end{tabular}




\begin{tabular}{|c|c|c|}
\hline \multirow{2}{*}{$\begin{array}{l}\text { FIRM NAME/ADDRESS/PHONE } \\
\text { Andco Actuator Products, Inc. } \\
\text { P. 0. Box } 988 \\
\text { Buffalo, New York } 14240 \\
\text { (716) } 681-7400\end{array}$} & $\begin{array}{c}\text { YEAR PRESENT FIRM ESTABLISHED } \\
1977\end{array}$ & $\begin{array}{l}\text { SURVEY DATE } \\
8-9-77\end{array}$ \\
\hline & $\begin{array}{l}\text { CONTACTS: } \text { NAME/TITLE/PHONE } \\
\text { Douglas D. Schumann/Vice Pres } \\
(716) 687-7400\end{array}$ & \\
\hline \multicolumn{3}{|c|}{$\begin{array}{l}\text { FORMER FIRM NAME, IF ANY, AND YEAR ESTABLISHED } \\
\text { Andco Incorporated - } 1907\end{array}$} \\
\hline \multicolumn{2}{|l|}{ PARENTI COMPANY } & Andco Industries, Inc. \\
\hline \multicolumn{3}{|c|}{\begin{tabular}{l|c|c} 
VALVE PLANT LOCATTONS & NUMBER OF EMPLOYEES & PLANT FLOOR SLACE \\
Buffalo, NY & 105 & $14,000 \mathrm{Sq} . \mathrm{Ft}$.
\end{tabular}} \\
\hline \multicolumn{3}{|c|}{$\begin{array}{l}\text { BRIEF STATEMENT AS TO } \triangle \text { CTUATOR PRONICTS } \\
\text { The Andco ACtuator is an electro-mechanical device to provide linear force in the } \\
\text { range of } 50 \text { to } 10,000 \text { pounds and motion up to } 60 \text { inches. It uses a standard } \\
\text { electric motor, conventional drive screw and a patented thrust overload protection } \\
\text { device. It can be equipped with various position control options. It requires } \\
\text { only electric power for operation. }\end{array}$} \\
\hline \multicolumn{3}{|c|}{$\begin{array}{l}\text { NOTE: Andco Metal Industry Products in conjunction with Andco Technical Services, } \\
\text { Ind., has provide specially designed high temperature valves and is } \\
\text { capable of designing and producing valves of the type required for coal } \\
\text { conversion. }\end{array}$} \\
\hline \multicolumn{3}{|c|}{$\begin{array}{l}\text { BRIEF STATEMENT AS TO DEVELOPNENTAL AND TESTING CAPABILITIES } \\
\text { Testing facilities currently exist for both production usage and ongoing product } \\
\text { development. The personnel possess the knowledge and experience to construct } \\
\text { additional testing facilities for any special requirements which may develop } \\
\text { from an inquiry such as the Oak Ridge National Laboratory letter of July } 15,1977 .\end{array}$} \\
\hline \multicolumn{3}{|c|}{$\begin{array}{l}\text { REMARKS: COMMENTS OF FUTURE PRODUCT LINES THAT MAY BE AVAILABLE BY 1982?, BY } 1987 ? \\
\text { Improvements, modifications and extensions of the actuator's capabilities are an } \\
\text { ongoing process. A rotary actuator incorporating the same design and integral } \\
\text { overload device is under development at this time. }\end{array}$} \\
\hline \multicolumn{3}{|c|}{ * LIST NAME AND ADDRESS AS YOU WOULD LIKE TO HAVE LISTEU IN THE FINAL REPORT } \\
\hline
\end{tabular}




\begin{tabular}{|c|c|c|c|}
\hline \multirow{2}{*}{$\begin{array}{l}\text { FIRM NAME/ADDRESS/PHONE } \\
\text { Anderson, Greenwood \& Co. } \\
5425 \text { S. Rice Ave. } \\
\text { Houston, TX } 77081 \\
713 / 668-0631\end{array}$} & \multicolumn{2}{|c|}{$\begin{array}{l}\text { YEAR PRESENT FIRM ESTABLISHED } \\
1947\end{array}$} & $\begin{array}{l}\text { SURVEY DATE } \\
7 / 1 / 77\end{array}$ \\
\hline & \multicolumn{3}{|c|}{$\begin{array}{l}\text { CONTACTS: NAME/TITLE/PHONE } \\
\text { Lomis Slaughter, Vice Pres. -Gen. Mgr. Special } \\
\text { Products Phone: } 713 / 668-0631\end{array}$} \\
\hline \multicolumn{4}{|c|}{$\begin{array}{l}\text { FORMER FIRM NAME, IF ANY, AND YEAR ESTABLISHED } \\
\text { Same }\end{array}$} \\
\hline \multicolumn{4}{|l|}{$\begin{array}{l}\text { PARENT COMPANY } \\
\text { Same }\end{array}$} \\
\hline $\begin{array}{l}\text { VALVE PLANT LOCATIONS } \\
\text { Same. }\end{array}$ & $\begin{array}{l}\text { BER OF EMPLOYEES } \\
520\end{array}$ & $\begin{array}{r}\text { PLAI } \\
169,3\end{array}$ & LOOR SPACE \\
\hline \multicolumn{4}{|c|}{$\begin{array}{l}\text { BRIEF STATEMENT AS TO STANDARD VALVE PRODUCTS } \\
\text { High and low pressure relief valves, gas and liquid pressure regulators. } \\
\text { Powerplant hand and powered globe valves to } 4 \text { inches packed and bellows sealed packless } \\
\text { instrument valves \& manifolds. Check valves to } 36 \text {-inch vacuum breaker fast response check } \\
\text { valves. }\end{array}$} \\
\hline \multicolumn{4}{|c|}{$\begin{array}{l}\text { BRIEF STATEMENT AS TO DEVELOPMENTAL AND TESTING CAPABILITIES } \\
\text { Test Facilities: ASME Certified } \\
\text { All pressures, flow test to } 500 \text { psi, low pressure flows to approximately } 50 \mathrm{lbs} \text {. air } / \mathrm{sec} \text {. } \\
\text { Product line in constant state of test and development } 1957 \text { to } 1977 \text { and continuing. }\end{array}$} \\
\hline \multicolumn{4}{|c|}{$\begin{array}{l}\text { REMARKS: COMMENTS OF FUTURE PRODUCT LINES THAT MAY BE AVAIIABLE BY 1982?, BY } 1987 ? \\
\text { As our management determines to be required by Petro-Chemical and Power Industry. }\end{array}$} \\
\hline $\begin{array}{l}\text { * LIST NAME AND ADDRESS AS } \\
\text { Anderson, Greenwood \& Co. } \\
\text { P. O. Box } 1097 \\
\text { Bellaire, TX } 77401 \text { Atin }\end{array}$ & STKE TO HAVE LIST & E FINA & EPORT \\
\hline
\end{tabular}




\begin{tabular}{|c|c|c|}
\hline \multirow{2}{*}{$\begin{array}{l}\text { FIRM NAME/ADDRESS/PHONE } \\
\text { Atwood \& Morrill Co., Inc. } \\
285 \text { Canal Street } \\
\text { Salem, Massachusetts } 01970 \\
(617) 744-5690\end{array}$} & $\begin{array}{c}\text { YEAR PRESENT FIRM ESTABLISHED } \\
1900\end{array}$ & $\begin{array}{l}\text { SURVEY DATE } \\
8-9-77\end{array}$ \\
\hline & \multicolumn{2}{|c|}{$\begin{array}{l}\text { CONTACTS: NAME/TITLE/PHONE } \\
\text { Robert A. Genier, Manager, Business } \\
(617) 744-5690 \quad \text { Development }\end{array}$} \\
\hline \multicolumn{3}{|c|}{$\begin{array}{l}\text { FORMER FIRM NAME, IF ANY, AND YEAR ESTABLISHED } \\
\text { None }\end{array}$} \\
\hline \multicolumn{3}{|c|}{$\begin{array}{l}\text { PARENT COMPANY } \\
\text { Foster Wheeler Energy Corporation }\end{array}$} \\
\hline \begin{tabular}{l|l} 
VAIVE PLANT LOC $\Lambda$ TIONS & \\
Salem, Massachusetts \\
Washington, North \\
Carolina
\end{tabular} & \begin{tabular}{l|r} 
BER OF EMPLOYEES & PLAN \\
& 115,0
\end{tabular} & $\begin{array}{l}\text { LOOR SPACE } \\
\text { s.f. }\end{array}$ \\
\hline \multicolumn{3}{|c|}{$\begin{array}{l}\text { BRIEF STATEMENT AS TO STANDARD VALVE PRODUCTS } \\
\text { Atwood \& Morrill manufacturers valves for the nuclear and fossil } \\
\text { power plants. Our principal lines are Steam Extract.inn rherk, Feen- } \\
\text { water checks, and Heater By-Pass for fossil stations; Main Steam } \\
\text { Isolation valves, Feedwater Isolation and Testable Check valves for } \\
\text { nuclear stations. In addition, Atwood \& Morrill supplies standard } \\
\text { Check and Gate valves for various systems in both. }\end{array}$} \\
\hline \multicolumn{3}{|c|}{$\begin{array}{l}\text { BRIEF STATEMENT AS TO DEVELOPMENTAL AND TESTING CAPABILITIES } \\
\text { Team of Design Engineers engages in developmental and testing } \\
\text { activities as dictated by contract needs. No fixed testing facilities } \\
\text { are in use, except for production fixtures and tests. In the last year } \\
\text { we have undertaken gas flow testing at } 10 \text { million \#/hour nitrogen, } \\
\text { bending and torsion testing to } 2.3 \text { million \#t. and are present.ly } \\
\text { designing steam test equipment for } 900 \text { psig sat. in a } 32 " \text { valve as a } \\
\text { production test. }\end{array}$} \\
\hline \multicolumn{3}{|c|}{$\begin{array}{l}\text { REMARKS: COMMENTS OF FUTURE PRODUCT LINES THAT MAY BE AVAILABLE BY 1982?, BY 1987? } \\
\text { It is anticipated that our current designs will be expanded to serve } \\
\text { new applications as the need arises. We also anticipate some } \\
\text { participation in designs as developed under contract for ERDA by } \\
\text { Foster wheeler. }\end{array}$} \\
\hline \multicolumn{3}{|c|}{$\begin{array}{l}\text { * LIST NAME AND ADDRESS AS YOU WOULD LIKE TO HAVE LISTED IN THE FIN } \Lambda \text { L REPORT } \\
\text { Atwood \& Morrill Co., Inc. } \\
285 \text { Canal Street } \\
\text { Salem, Massachusetts } 01970\end{array}$} \\
\hline
\end{tabular}




\begin{tabular}{|c|c|}
\hline \multirow{2}{*}{$\begin{array}{l}\text { FIRM NAME/ADDRESS/PHONE } \\
\text { Automatic Switch Company } \\
\text { Hanover Road } \\
\text { Florham Park, NJ } 07932 \\
\text { (201) } 966-2000\end{array}$} & \begin{tabular}{c|c} 
YEAR PRESENT FIRM ESTABLISHED & SURVEY DATE \\
1888 & $7 / 6 / 77$
\end{tabular} \\
\hline & $\begin{array}{l}\text { CONTACTS: NAME/TITLE/PHONE } \\
\text { H. H. Kaemmer, Manager, Valve Department } \\
(201) 966-2050\end{array}$ \\
\hline \multicolumn{2}{|c|}{$\begin{array}{l}\text { FORMER FIRM NAME, IF AINY, AND YEAR ESTABLISHED } \\
\text { None }\end{array}$} \\
\hline \multicolumn{2}{|l|}{$\begin{array}{l}\text { PARENT COMPANY } \\
\text { None }\end{array}$} \\
\hline $\begin{array}{l}\text { VALVE PLANT LOCATIONS } \\
\text { Florham Park, NJ } \\
\text { Chicago, IL, LOS Angeles, CA }\end{array}$ & \begin{tabular}{l|r} 
BER OF EMPLOYEES & PLANT FLOOR SPACE \\
400 & $450,000 \mathrm{sq} . \mathrm{Ft}$.
\end{tabular} \\
\hline \multicolumn{2}{|c|}{$\begin{array}{l}\text { BRIEF STATEMENT AS TO STANDARD VALVE PRODUCTS } \\
\text { Solenoid and air operated valves, electromagnetically or air operated control } \\
\text { equipment used to deliver or interrupt the flow of liquids and gases automatically } \\
\text { or on command to operate all kinds of tools, equipment, machinery, and processes. } \\
\text { These valves are also utilized to pilot large valves which are diaphragm or piston } \\
\text { controlled. }\end{array}$} \\
\hline \multicolumn{2}{|c|}{$\begin{array}{l}\text { BRIEF STATEMENT AS TO DEVELOPMENTAL AND TESTIIVG CAPABILITIES } \\
\text { Great emphasis is placed on research, development, and engineering. Of the com- } \\
\text { pany's total US staff of more than } 1400 \text {, some } 250 \text { are graduate engineers, drafts- } \\
\text { men, and laboratory personnel engaged in R\&D and engineering activity. }\end{array}$} \\
\hline \multicolumn{2}{|c|}{$\begin{array}{l}\text { REMARKS: COMMENTS OF FUTURE PRODUCT LINES THAT MAY BE AVATLABLE BY 1982?, BY 1987? } \\
\text { Constantly updating present products and adding new designs as field technology } \\
\text { changes dictate. }\end{array}$} \\
\hline \multicolumn{2}{|c|}{$\begin{array}{l}\text { * LIST NAME AND ADDRESS AS YOU WOULD LIKE TO HAVE LISTED IN THE FINAL REPORT } \\
\text { H. H. Kaemmer, Manager, Valve Department } \\
\text { Automatic Switch Company } \\
\text { Hanover Road } \\
\text { Florham Park, NJ } 07932\end{array}$} \\
\hline
\end{tabular}




\begin{tabular}{|c|c|c|}
\hline \multirow{2}{*}{$\begin{array}{l}\text { FIRM NAME/ADDRESS/PHONE } \\
\text { Bingham-Willamette Company } \\
2800 \text { N.W. Front Avenue } \\
\text { Portland, OR } 97210 \\
\text { (503) } 226-5200\end{array}$} & $\begin{array}{l}\text { YE } \Lambda \text { RRESENT FIRM ESTABLISHED } \\
1946\end{array}$ & $\begin{array}{l}\text { SURVEY DATE } \\
6 / 23 / 77\end{array}$ \\
\hline & \multicolumn{2}{|c|}{$\begin{array}{l}\text { CONTACTS: NAME/TITLE/PHONE } \\
\text { Paul S. Nieswander, Manager } \\
\text { Valve Department } \quad(503) 226-5215\end{array}$} \\
\hline \multicolumn{3}{|c|}{$\begin{array}{l}\text { FORMER FIRM NAME, IF ANY, AND YEAR ESTABLISHED } \\
\text { Willamette Iron Works } \quad 1865\end{array}$} \\
\hline \multicolumn{3}{|l|}{$\begin{array}{l}\text { PARENT COMPANY } \\
\text { Guy F. Atkinson Company }\end{array}$} \\
\hline $\begin{array}{l}\text { VALVE PLANT LOCATIONE } \\
2800 \text { NW Front Avenue } \\
\text { Portland, OR } 97210\end{array}$ & $\begin{array}{l}\text { STIR OT IMTLOYDDO } \\
000\end{array}$ & $\begin{array}{l}\text { LOOR JFACE } \\
\text { Sq. Ft. }\end{array}$ \\
\hline \multicolumn{3}{|c|}{$\begin{array}{l}\text { BRIEF STATEMENT AS TO STNNDARD VALVE PRODUCTS } \\
\text { Willamette List } 26 \text { Ball Valve - Metal Seats, } \\
150 \text { psi and } 300 \text { psi pressure range - Max. Temperature } 180^{\circ} \mathrm{F}\end{array}$} \\
\hline \multicolumn{3}{|c|}{$\begin{array}{l}\text { BRIEF STATEMENT AS TO DEVELOPMENTAL AND TESTING CAPABILITIES } \\
2 \text { Nuclear Test Loops } \\
\text { Seal Test Area } \\
\text { Pump Test Area } \\
\text { Valve Test Area }\end{array}$} \\
\hline \multicolumn{3}{|c|}{$\begin{array}{l}\text { REMARKS: COMMENTS OF FUTURE PRODUCT LINES THAT MAY BE AVAILABLE BY 1982?, BY } 1987 ? \\
\text { Slurry Valves }\end{array}$} \\
\hline $\begin{array}{l}\text { * LIST NAME AND ADDRESS AS } \\
\text { Bingham-Willamette Company } \\
2800 \text { NW Front Avenue } \\
\text { Portland, OR } 97210\end{array}$ & LIKE TO HAVE LISTED IIN THE FIN & EPORT \\
\hline
\end{tabular}




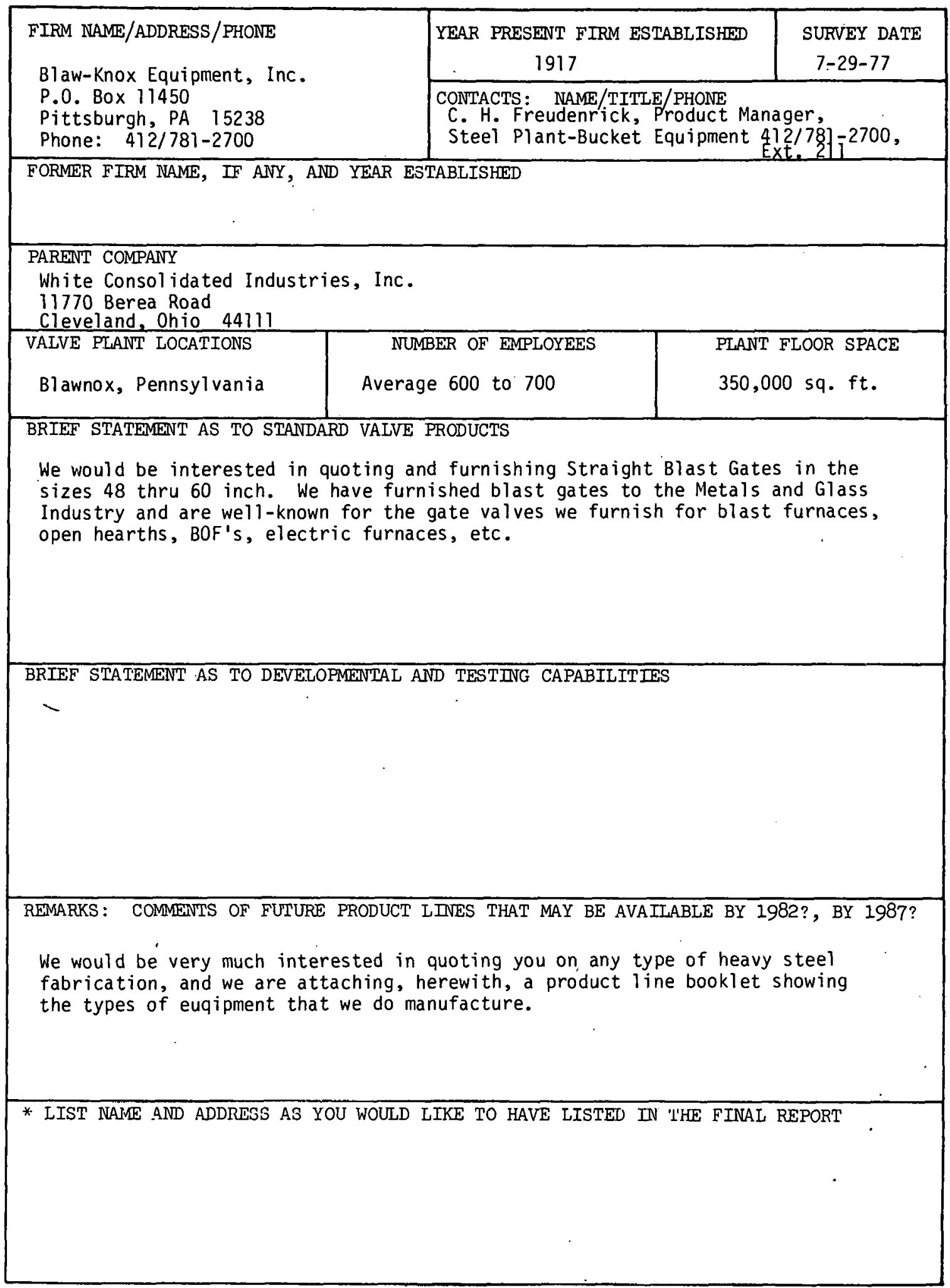




\begin{tabular}{|c|c|c|}
\hline \multirow{2}{*}{$\begin{array}{l}\text { FIRM NAME/ADDRESS/PHONE } \\
\text { C-E INVALCO } \\
\text { P. O. BOX } 556 \\
1305 \text { N. Louisville } \\
\text { Tulsa, OK } 74101\end{array}$} & $\begin{array}{l}\text { YEAR PRESENT FIRM ESTABLISHED } \\
\text { INVALCO Since } 1962\end{array}$ & $\begin{array}{l}\text { SURVEY DATE } \\
7-12-77 \\
\end{array}$ \\
\hline & \multicolumn{2}{|l|}{ CONTACTS: $\quad$ NAME/TITLE/PHONE } \\
\hline \multicolumn{3}{|c|}{$\begin{array}{l}\text { FORMER FIRM NAME, IF ANY, AND YEAR ESTABLISHED } \\
\text { INSTRUMENTS, INC., Established in } 1948\end{array}$} \\
\hline Combustion Engineering, Inc. & \multicolumn{2}{|c|}{ PARENT COMPANY } \\
\hline $\begin{array}{l}\text { VALVE PLANT LOCATIONS } \\
1305 \text { N. LOU ISville } \\
\text { Tulsa, OK. }\end{array}$ & \begin{tabular}{l|r} 
BER OF EMPLOYEES & PLAI \\
175,00
\end{tabular} & $\begin{array}{l}\text { LOOR SPACE } \\
\text { q. Ft. }\end{array}$ \\
\hline \multicolumn{3}{|c|}{$\begin{array}{l}\text { (1) 1/4" through 6" Diaphragm Actuators; } 2 \text { \& } 3 \text { way Globe and Angl } \\
\text { Pressures up to } 6000 \text { psi. Body materials Steel and Ductile Ir } \\
\text { (2) Long Nose Chokes. Maximum Working Pressure } 6500 \text { ps } 1 \text {. } \\
\text { (3) 2" Coal Slurry Control Valve }\end{array}$} \\
\hline \multicolumn{3}{|c|}{$\begin{array}{l}\text { BRIEF STATEMENT AS TO DEVELOPMEINTAL AND TESTING CAPABILITIES } \\
\text { Fully equipped Research and Development Departments. Testing facilities for } \\
\text { hydrostatic pressure tests up to } 15,000 \text { psig. }\end{array}$} \\
\hline \multicolumn{3}{|c|}{$\begin{array}{l}\text { REMARKS: COMMENTS OF FUTURE PRODUCT LINES THAT MAY BE AVAILABLE BY 1982?, BY } 1987 ? \\
\text { We do not anticipate at this time, that Invalco will be manufacturing the types of } \\
\text { products which will meet your requirements. }\end{array}$} \\
\hline \multicolumn{3}{|c|}{$\begin{array}{l}\text { * LIST NAME AND ADDRESS AS YOU WOULD LIKE TO HAVE LISTED IN THE FINAL REPORT } \\
\text { C-E INVALCO } \\
\text { P. 0. BOX } 556 \\
\text { Tulsa, OK } 74101\end{array}$} \\
\hline
\end{tabular}




\begin{tabular}{|c|c|c|}
\hline \multirow{2}{*}{$\begin{array}{l}\text { FIRM NAME/ADDRESS/PHONE } \\
\text { Calmec } \\
8401 \text { E. Siauson } \\
\text { Pico Rivera, CA } 90660 \\
\text { (213) 723-8581 }\end{array}$} & \multirow{2}{*}{$\begin{array}{l}\text { YEAR PRESENT FIRM ESTABLISHED } \\
1928 \\
\text { CONTACTS: NAME/TITLE/PHONE } \\
\text { Keith Rogers } \\
\text { Marketing Manager }\end{array}$} & \multirow{2}{*}{$\frac{\text { SURVEY . DATE }}{\ddots}$} \\
\hline & & \\
\hline \multicolumn{3}{|c|}{$\begin{array}{l}\text { FORMER FIRM NAME, IF ANY, AND YEAR ESTABLISHED } \\
\text { None }\end{array}$} \\
\hline \multicolumn{3}{|l|}{$\begin{array}{l}\text { PARENT COMPANY } \\
\text { Ametek }\end{array}$} \\
\hline \multicolumn{3}{|c|}{\begin{tabular}{c|c|c} 
VALVE PLANT LOCATIONS & NUMBER OF EMPLOYEES & PLANT FLOOR SPACE \\
Pico Rivera, CA & 186 & $100,000 \mathrm{sq} . \mathrm{ft}$. \\
\end{tabular}} \\
\hline \multicolumn{3}{|c|}{$\begin{array}{l}\text { BRIEF STATEMENT AS TO STANDARD VALVE PRODUCTS } \\
\text { Specialty products used in Aerospace, nuclear and commercial applications from } \\
-423^{\circ} \mathrm{F} \text { to }+1200^{\circ} \mathrm{F} \text {, pressures to } 30,000 \mathrm{psi} \text {. Includes ball, globe and butterfly } \\
\text { types for cryogenic liquids, steam, water, corrosives, molten metals and gases. }\end{array}$} \\
\hline \multicolumn{3}{|c|}{$\begin{array}{l}\text { BRIEF STATEMENT AS TO DEVELOPMENTAL AND TESTING CAPABILITIES } \\
\text { Capabilities include a class } 1 \text { clean room, liquid nitrogen and water flow facilitie } \\
\text { gaseous hel ium and air. Calmec has a staffed Engineering Department and a short } \\
\text { order shop for development parts fabrication. More exotic test facilities are } \\
\text { available locally. }\end{array}$} \\
\hline \multicolumn{3}{|c|}{$\begin{array}{l}\text { REMARKS: COMMENTS OF FUTURE PRODUCT LINES THAT MAY BE AVAIIABLE BY 1982?, BY } 1987 ? \\
\text { Product line will include a full complement of nuciear rate globe, ball and } \\
\text { butterfly valves, in addition to ASNI rated specialty bellows seal valves. } \\
\text { Cryogenic control valves, regulators and automatic disconnect valves are currently } \\
\text { in the product line, as are burst disc and relief valve assemblies. }\end{array}$} \\
\hline \multicolumn{3}{|c|}{ * IIST INAME AND ADDRFSS AS YOTI WOITID LIKE TO HAVE LISTED IIN THE FINAL REPORT } \\
\hline
\end{tabular}




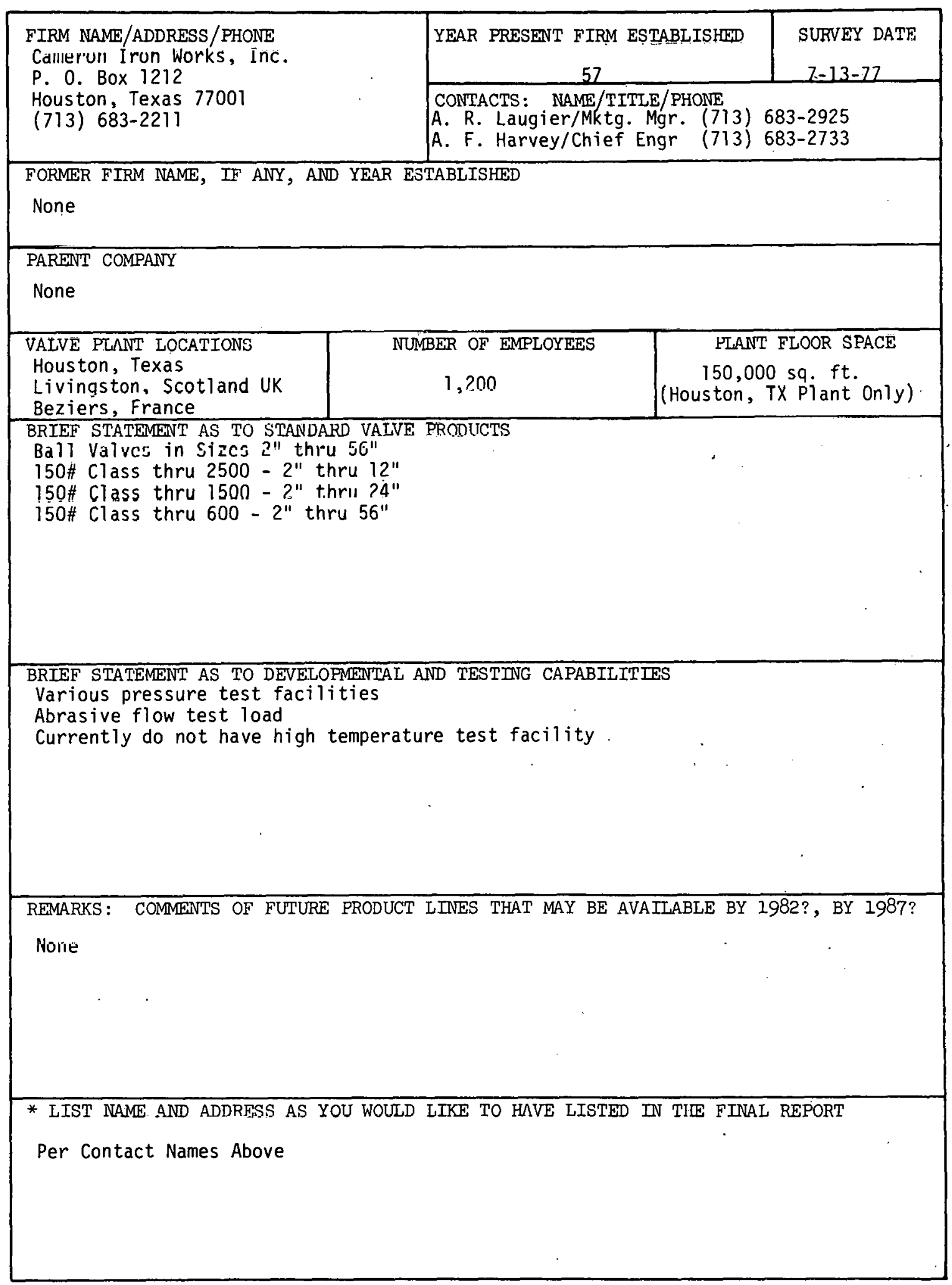




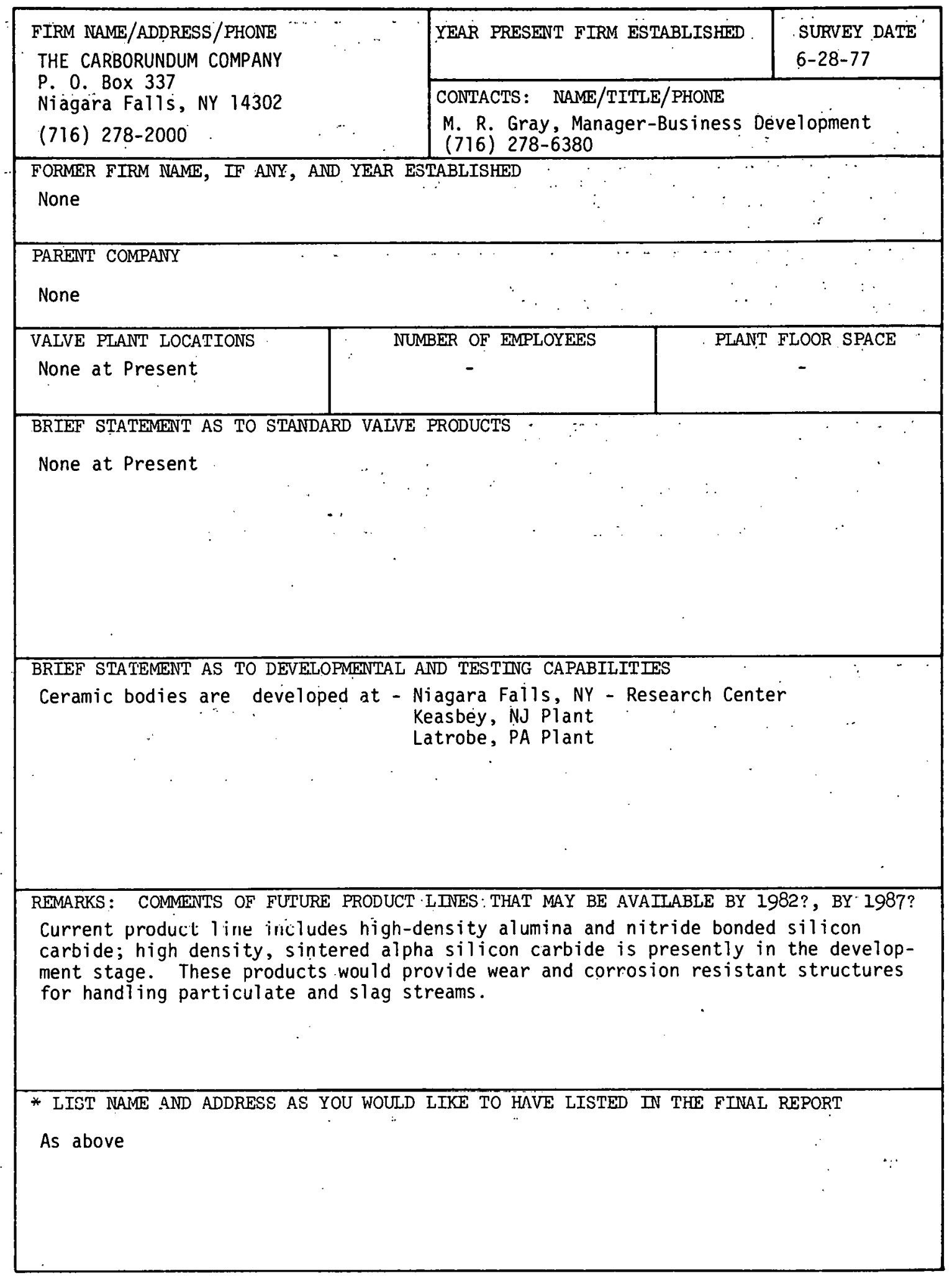




\begin{tabular}{|c|c|c|}
\hline \multirow{2}{*}{$\begin{array}{l}\text { TTRM NAME/ } \triangle \text { DDRESS/PHONE } \\
\text { CIRCLE SEAL CONTROLS } \\
\text { Brunswick Corp, Technetics Div. } \\
\text { P. O. Box } 3666 \\
\text { Anaheim, CA } 92803 \\
\text { (714) } 774-6110\end{array}$} & $\begin{array}{c}\text { YRAR TRESENT FIRM ESTABLISHEU } \\
1977\end{array}$ & SURVEY LA'L'E' \\
\hline & \multicolumn{2}{|c|}{$\begin{array}{l}\text { CONTACTS: NAME/TITLE/PHONE } \\
\text { Bob Crowell, Product, Mgr., Hex Engineering } \\
\text { Frank Distel, Sr. Application Engineer }\end{array}$} \\
\hline \multicolumn{3}{|c|}{$\begin{array}{l}\text { FORMER FIRM NAME, IF ANY, AND YEAR ESTABLISHED } \\
\text { Circle Seal Corporation - } 1969 \\
\text { James-Pond-Clark - } 1951\end{array}$} \\
\hline \multicolumn{3}{|c|}{$\begin{array}{l}\text { PARENT COMPANY } \\
\text { Brunswick Corporation, Technetics Div. } \\
\text { One Brunswick Plaza, Skokie, IL } 60076\end{array}$} \\
\hline \multicolumn{3}{|c|}{\begin{tabular}{l|c|c|} 
VALVE PLANT LOCATIONE & NUMDIR OF EMPLOYEES & PLAIVT FLUUR SFALE \\
Anaheim, CA & 400 & $90,000 \mathrm{Sq} . \mathrm{Ft}$.
\end{tabular}} \\
\hline \multicolumn{3}{|c|}{$\begin{array}{l}\text { BRIEF STATEMENT AS TO STANDARD VALVE PRODUCTS } \\
\text { Check valves, relief valves, pressure regulators, metering valves, manually } \\
\text { operated shutoff valves, solenoids, filters (in iine sizes up through } 2^{\prime \prime} \text { ). We } \\
\text { manufacture these in various types of stainless steel, carbon steel, brass, } \\
\text { aluminum and, on special request, will furnish these in other more exotic materials. }\end{array}$} \\
\hline \multicolumn{3}{|c|}{$\begin{array}{l}\text { BRIEF STATEMENT AS TO DEVELOPMENTAL AND TESTING CAPABILITIES } \\
\text { Our in-plant sources for high pressure testing include both pneumatic systems up } \\
\text { to } 6000 \text { psi operating pressure for air and helium. We have a hydraulic test } \\
\text { capability up to } 500 \text { psi with flow rates as high as } 5000 \text { psi. Our pneumatic } \\
\text { system has a capability of flowing upwards to } 10,000 \text { standard cubic feet per minute } \\
\text { for short durations. }\end{array}$} \\
\hline \multicolumn{3}{|c|}{$\begin{array}{l}\text { REMARKS: COMMENTS OF FUTURE PRODUCT LINES THAT MAY BE AVAILABLE BY 1982?, BY 1987? } \\
\text { We have made plug type and shutoff valves which are capable of being used for } \\
\text { sampling high pressure process streams and/or being rodded out. }\end{array}$} \\
\hline \multicolumn{3}{|c|}{$\begin{array}{l}\text { * LIST NAME AND ADDRESS AS YOU WOULD LIKE TO HAVE LISTED IN THE FINAL REPORT } \\
\text { CIRCLE SEAL CONTROLS } \\
\text { Brunswick Corp., Technetics Div. } \\
\text { P. O. Box } 3666 \\
\text { Anaheim, CA } 92803\end{array}$} \\
\hline
\end{tabular}




\begin{tabular}{|c|c|c|c|}
\hline \multirow{2}{*}{$\begin{array}{l}\text { FIRM NAME/ADDRESS/PHONE } \\
\text { Cleveland Armstrong Company } \\
1108 \text { So. Kilburn } \\
\text { Chicago, I1l. } 60624 \\
\text { (312) 826-0406 }\end{array}$} & \multicolumn{2}{|c|}{$\begin{array}{l}\text { YEAR PRESENT FIRM ESTABLISHED } \\
1963\end{array}$} & $\begin{array}{c}\text { SURVEY DATE } \\
7-5-77\end{array}$ \\
\hline & \multicolumn{3}{|c|}{$\begin{array}{l}\text { CONTACTS: } \text { NAME/TITLE/PHONE } \\
\text { Peter Coster, General Mgr. }\end{array}$} \\
\hline \multicolumn{4}{|c|}{$\begin{array}{l}\text { FORMER FIRM NAME, IF ANY, AND YEAR ESTABLISHED } \\
\text { Armstrong Valve Company } 1959\end{array}$} \\
\hline \multicolumn{4}{|l|}{ Research Cottrell } \\
\hline $\begin{array}{l}\text { VALVE PLANT LOCATIONS } \\
\text { Same Address }\end{array}$ & $\begin{array}{l}\text { BER OF EMPLOYEES } \\
25\end{array}$ & $\begin{array}{r}\text { PLAN? } \\
200\end{array}$ & $\begin{array}{l}\text { LOOR SPACE } \\
0 \text { sq. ft. }\end{array}$ \\
\hline $\begin{array}{l}\text { BRIEF STATEMENT AS TO STANDA } \\
\text { Valves for dry dulk materia } \\
\text { 1. Shut-0ff Gates. } \\
\text { 2. Diverters } \\
\text { 3. Air lock on pressure di }\end{array}$ & $\overline{\text { PRODUCTS }}$ & & \\
\hline
\end{tabular}

BRIEF STATEMENT AS TO DEVELOPMENTAL AND TESTING CAPABILITIES

Test for sealing capability

REMARKS: COMMENTS OF FUTURE PRODUCT LINES THAT MAY BE AVATLABLE BY 1982?, BY 1987?

Valves for pulverized fuels - 1902

* LIST NAME AND ADDRESS AS YOU WOULD LIKE TO HAVE LISTED IN THE FINAL REPORT Same as above 


\begin{tabular}{|c|c|}
\hline \multirow{2}{*}{$\begin{array}{l}\text { FIRM NAME/ADDRESS/PHONE } \\
\text { Clow Corp. , Engineered Products Div. } \\
40 \text { Chestnut Avenue } \\
\text { Westmont, IL } 60559\end{array}$} & $\begin{array}{l}\text { YEAR PRESENT FIRM ESTABLISHED } \\
19 / 4\end{array}$ \\
\hline & $\begin{array}{l}\text { CONTACTS: NAME/TITLE/PHONE. } \\
\text { J. Phi } 1 \text { ip El lenberger, Marketing Manager } \\
\text { (312) } 325-6000\end{array}$ \\
\hline \multicolumn{2}{|c|}{$\begin{array}{l}\text { FORMER FIRM NAME, IF ANY, AND YEAR ESTABLISHED } \\
\text { None }\end{array}$} \\
\hline \multicolumn{2}{|l|}{ PARENT COMPANY } \\
\hline \begin{tabular}{l|l|l} 
VALVE PLANT LOCATIONS & NUM \\
Westmont, IL &
\end{tabular} & \begin{tabular}{l|l} 
BER OF EMPLOYEES & FLANT FLOOR SPACE \\
$50+$ & $47,000 \mathrm{sq} \mathrm{ft}$.
\end{tabular} \\
\hline \multicolumn{2}{|c|}{$\begin{array}{l}\text { BRIEF STATEMENT AS TO STANDARD VALVE PRODUCTS } \\
\text { Clow, Engineered Products manufactures the Clow Tricentric, basic design. They } \\
\text { also make special adaptations of valves of special materials and designs and } \\
\text { related systems designed to the specific process requirements. All products are } \\
\text { fabricated. }\end{array}$} \\
\hline \multicolumn{2}{|c|}{$\begin{array}{l}\text { BRIEF STATEMENT AS TO DEVELOPMENTAL AND TESTING CAPABILITIES } \\
\text { Clow, the parent company, has R\&D section. Engineered Products has internal } \\
\text { stress, seismic, etc. capabilities. } \\
\text { Standard hydro tests and NDE are performed in-house. We have relationships with } \\
\text { several testing laboratories. Clow also has relationships with firms in Europe } \\
\text { for development. }\end{array}$} \\
\hline \multicolumn{2}{|c|}{$\begin{array}{l}\text { REMARKS: COMMENTS OF FUTURE PRODUCT LINES THAT MAY BE AVAILABLE BY 1982?, BY 1987? } \\
\text { Engineered Products is seeking product lines that relate to high temp, corros,ive } \\
\text { atmosphere, severe service flow control. }\end{array}$} \\
\hline $\begin{array}{l}\text { * LIST NAME AND ADDRESS AS YOU WOULD } \\
\text { As stated in CONTACTS }\end{array}$ & LIKE TO HAVE LISTED IN THE FINAL REPORT \\
\hline
\end{tabular}




\begin{tabular}{|c|c|c|}
\hline \multirow{2}{*}{$\begin{array}{l}\text { FIRM NAME/ADDRESS/PHONE } \\
\text { CODECAL InC. } \\
\text { PO Vox } 428 \\
382 \text { Springfield Avenue } \\
\text { Summit, New Jersey } 07901 \\
\text { (201) } 273-2434\end{array}$} & $\begin{array}{l}\text { YEAR PRESENT FIRM ESTABLISHED } \\
1968\end{array}$ & $\begin{array}{l}\text { SURVEY DATE } \\
9 / 1 / 77 \\
\end{array}$ \\
\hline & \multicolumn{2}{|c|}{ 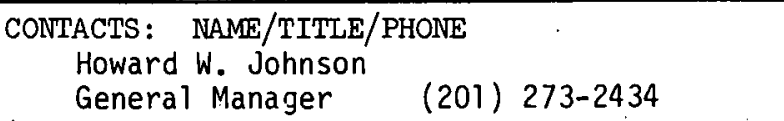 } \\
\hline \multicolumn{3}{|c|}{$\begin{array}{l}\text { FORMER FIRM NAME, IF ANY, AND YEAR ESTABLISHED } \\
\text { Control Devices, Inc. } \quad 1968\end{array}$} \\
\hline \multicolumn{3}{|l|}{$\begin{array}{l}\text { PARENTI COMPANY } \\
\text { CODECAL InC. }\end{array}$} \\
\hline $\begin{array}{l}\text { VALVE PLANT LOCATIONS } \\
637 \text { W. Val encia Drive } \\
\text { Fullerton, California. }\end{array}$ & $\begin{array}{l}\text { BER OF EMPLOYEES } \\
10\end{array}$ & $\begin{array}{l}\text { LOOR SPACE } \\
\text { sq. ft. }\end{array}$ \\
\hline \multicolumn{3}{|c|}{$\begin{array}{l}\text { BRIEF STATEMENT AS TO STANDARD VALVE PRODUCTS } \\
\text { As manufacturers, the -following: } \\
\text { Pressure limiters (see attached catalog), check valves, relief valves, pressure } \\
\text { regulators, excess-flow valves, etc. } \\
\text { As engineers we are valve designers. }\end{array}$} \\
\hline \multicolumn{3}{|c|}{$\begin{array}{l}\text { BRIEF STATEMENT AS TO DEVELOPMENTAL AND TESTING CAPABILITIES } \\
\text { See attached copy of our Capabilities \& Facilities brochure. }\end{array}$} \\
\hline REMARKS: COMMENTS OF FUTURE & LINES THAT MAY BE AVAILABLE BY & 2?, BY 1987? \\
\hline $\begin{array}{l}\text { * LIST NAME AND ADDRESS AS YC } \\
\text { CODECAL INC. } \\
\text { P.0. BOX } 428 \\
\text { Summit, New Jersey }\end{array}$ & LIKE TO HAVE LISTED IN THE I'INAI & EPORT \\
\hline
\end{tabular}




\begin{tabular}{|c|c|c|}
\hline \multirow{2}{*}{$\begin{array}{l}\text { FIRM NAME/ADDRESS/PHONE } \\
\text { Consolidated Controls Corp. } \\
2338 \text { Alaska Avenue } \\
\text { El Segundo, CA } 90245\end{array}$} & $\begin{array}{c}\text { YEAR PRESENT FIRM ESTABLISHED } \\
1958\end{array}$ & $\begin{array}{l}\text { SURVEY DATE } \\
7-12-77\end{array}$ \\
\hline & \multicolumn{2}{|c|}{$\begin{array}{l}\text { CONTACTS: NAME/TITLE/PHONE } \\
\text { T. E. Jackson/Sr. Contract Administrator } \\
\text { (213) } 776-5301, \times 233\end{array}$} \\
\hline \multicolumn{3}{|c|}{$\begin{array}{l}\text { FORMER FIRM NAME, IF ANY, AND YEAR ESTABLISHED } \\
\text { None }\end{array}$} \\
\hline \multicolumn{3}{|c|}{$\begin{array}{l}\text { PARENT COMPANY } \\
\text { Condec Corp., } 1700 \text { Post Road, old Greenwich, CT } 06870\end{array}$} \\
\hline \multicolumn{3}{|c|}{\begin{tabular}{l|c|c} 
VALVE PLANT LOCATIONS & NUMBER OF EMPLOYEES & PLANT FLOOR SPACE \\
El seyundu & 100 & $40,00034 . \mathrm{Fl}$.
\end{tabular}} \\
\hline \multicolumn{3}{|c|}{$\begin{array}{l}\text { BRIEF STATEMENT AS TO STANDARD VALVE PRODUCTS } \\
\text { SEe enclosed document "FLOW CONTROL DEVICES FOR COAL CONVERSION PROCESSES". } \\
\text { NOTE: (1) Supplier of high temperature, high pressure valves for aerospace. } \\
\text { (2) Products include ceramic and castable aluminum lined valves. } \\
\text { (3) Has ERDA lined valve development contract. }\end{array}$} \\
\hline \multicolumn{3}{|c|}{$\begin{array}{l}\text { BRIEF STATEMENT AS TO DEVELOPMENTAL AND TESTING CAPABILITIES } \\
\text { CCC has specialized in the design and development of unique flow control devices } \\
\text { for over } 25 \text { years. All of the flow control equipment produced by CCC has been } \\
\text { developed to specific customer requirements. All equipment is tested to the max. } \\
\text { operating condition. Equipment size range up to } 6 \text { tons and testing from }-320 \text { to } \\
+2000^{\circ} \mathrm{F} \text { and pressure up to } 10,000 \text { psig gas and } 20,000 \text { psig fluid. }\end{array}$} \\
\hline \multicolumn{3}{|c|}{$\begin{array}{l}\text { REMARKS: COMMENTS OF FUTURE PRODUCT LINES THAT MAY BE AVATLABLE BY 1982?, BY 1987? } \\
\text { Currently we have production capability for our Sol ids Control Valve } 7440 \text {, Main } \\
\text { Steam Root Valve } 73405 \text {, and Rotary Feeder Valve } 74450 \text {. } \\
\text { In addition, we have an ongoing program for design and manufacture of } 24-\text { inch } \\
\text { coal gasification control valves used in the coal lock-hopper feed system. } \\
\text { Production capability for these valves will be available by } 1978 \text {. }\end{array}$} \\
\hline \multicolumn{3}{|c|}{$\begin{array}{l}\text { * IIST NAME AND ADDRESS AS YOU WOULD LIKE TO HAVE LISTED IN THE FINAL REPORT } \\
\text { Consol idated Controls Corporation } \\
2338 \text { Alaska Avenue } \\
\text { El Segundo, CA } 90245\end{array}$} \\
\hline
\end{tabular}




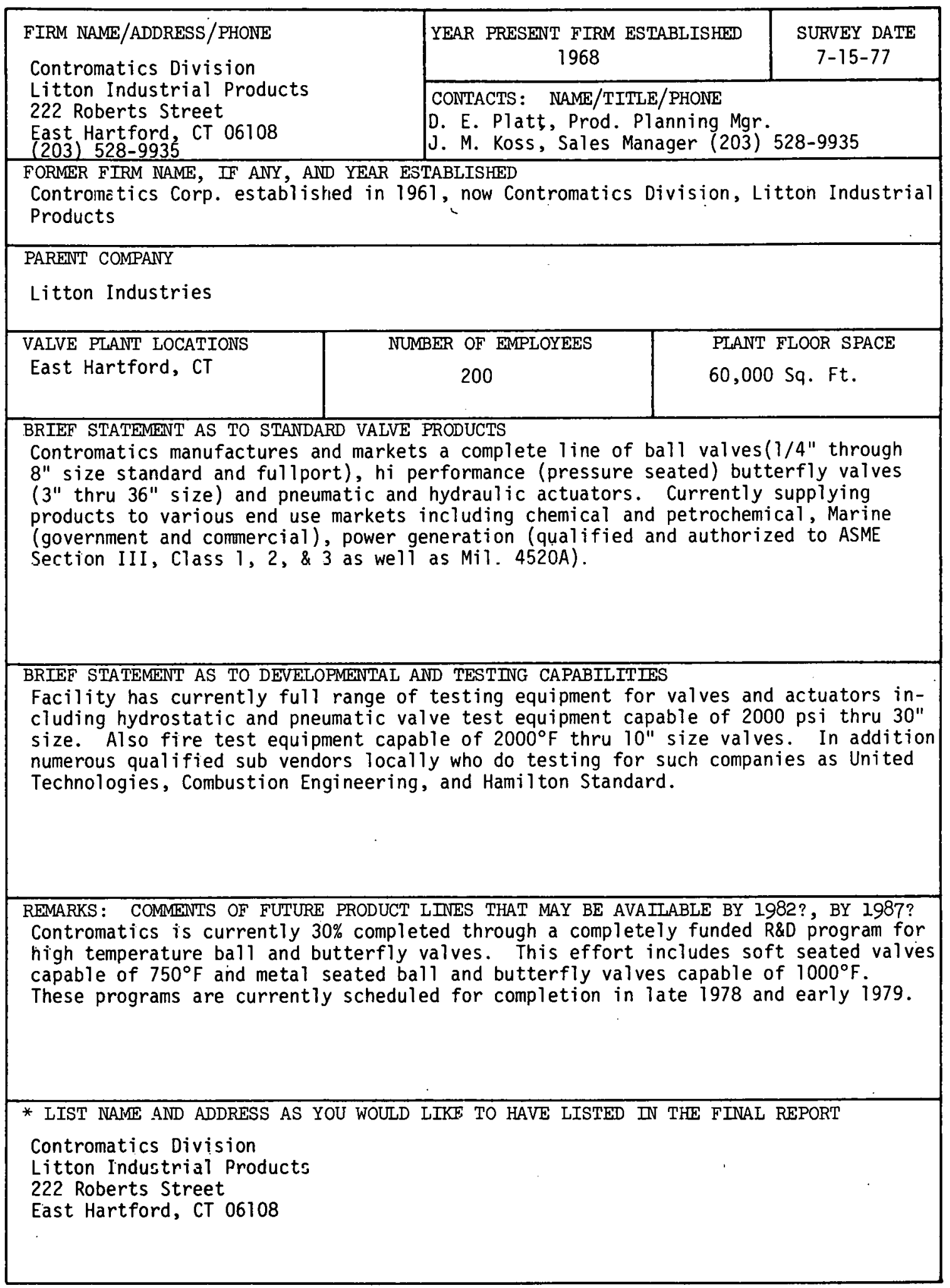




\begin{tabular}{|c|c|c|}
\hline \multirow{2}{*}{$\begin{array}{l}\text { FIRM NAME/ADDRESS/PHONE } \\
\text { Crane Co. } \\
300 \text { Park Avenue } \\
\text { New York, New York } 10022\end{array}$} & $\begin{array}{l}\text { YEAR PRESENT FIRM ESTABLISHED } \\
1855\end{array}$ & $\begin{array}{l}\text { SURVEY DATE } \\
6 / 30 / 7 ?\end{array}$ \\
\hline & \multicolumn{2}{|c|}{$\begin{array}{l}\text { CONTACTS: NAME/TITLE/PHONE } \\
\text { Mr. William C. Dackis, Vice President } \\
212-980-7204\end{array}$} \\
\hline \multicolumn{3}{|c|}{ FORMER FIRM NAME, IF ANY, AND YEAR ESTABLISHED } \\
\hline \multicolumn{3}{|l|}{ PARENT COMPANY } \\
\hline $\begin{array}{l}\text { VALVE PLANT LOCATIONS } \\
\text { Chicago; Chattanooga; } \\
\text { Indian Orchard, Mass.; } \\
\text { Washington, Iowa; Rogers, Ark }\end{array}$ & \begin{tabular}{l|r|} 
BER OF EMPLOYEES & PLAI \\
$-21,850$ & Valve P \\
Div. Crane USA - & \\
2,465 & \\
\end{tabular} & $\begin{array}{l}\text { FLOOR SPACE } \\
\text { nts }-5 \\
, 541,000 \mathrm{sq} \cdot \mathrm{ft}\end{array}$ \\
\hline \multicolumn{3}{|c|}{$\begin{array}{l}\text { BRIEF STATEMENT AS TO STANDARD VALVE PRODUCTS } \\
\text { Full line of gate, globe, check, ball and butterfly valves of steel, iron and } \\
\text { bronze materials in size ranges } 1 / 8^{\prime \prime} \text { up to } 108^{\prime \prime} \text { as appropriate for pressure } \\
\text { ranges from vacuum to } 30,000 \mathrm{psi} \text { and temperatures from ambient to } 1600 \mathrm{~F} \text {. }\end{array}$} \\
\hline
\end{tabular}

BRIEE STATEMENT AS TO DEVELOPMEINTAL AND TESTING CAPABILITIES

Hydrostatic pressure to $50,000 \mathrm{psi}$. Steam testing to $350 \mathrm{psi}$ saturated steam. Operational test stands for a wide variety of conditions including performance testing with applied nozzle loads. Flow test capability for pressure drop and throttling performancc dctcrmination. Strain gage and related structures testing.

REMARKS: COMMENTS OF FUTURE PRODUCT LINES THAT MAY BE AVAIIABLE BY 1982?, BY 1987?

* LIST NAME AND ADDRESS AS YOU WOULD LIKE TO HAVE LISTED IN THE FINAL REPORT

Crane Co.

300 Park Avenue

New York, New York 10022 


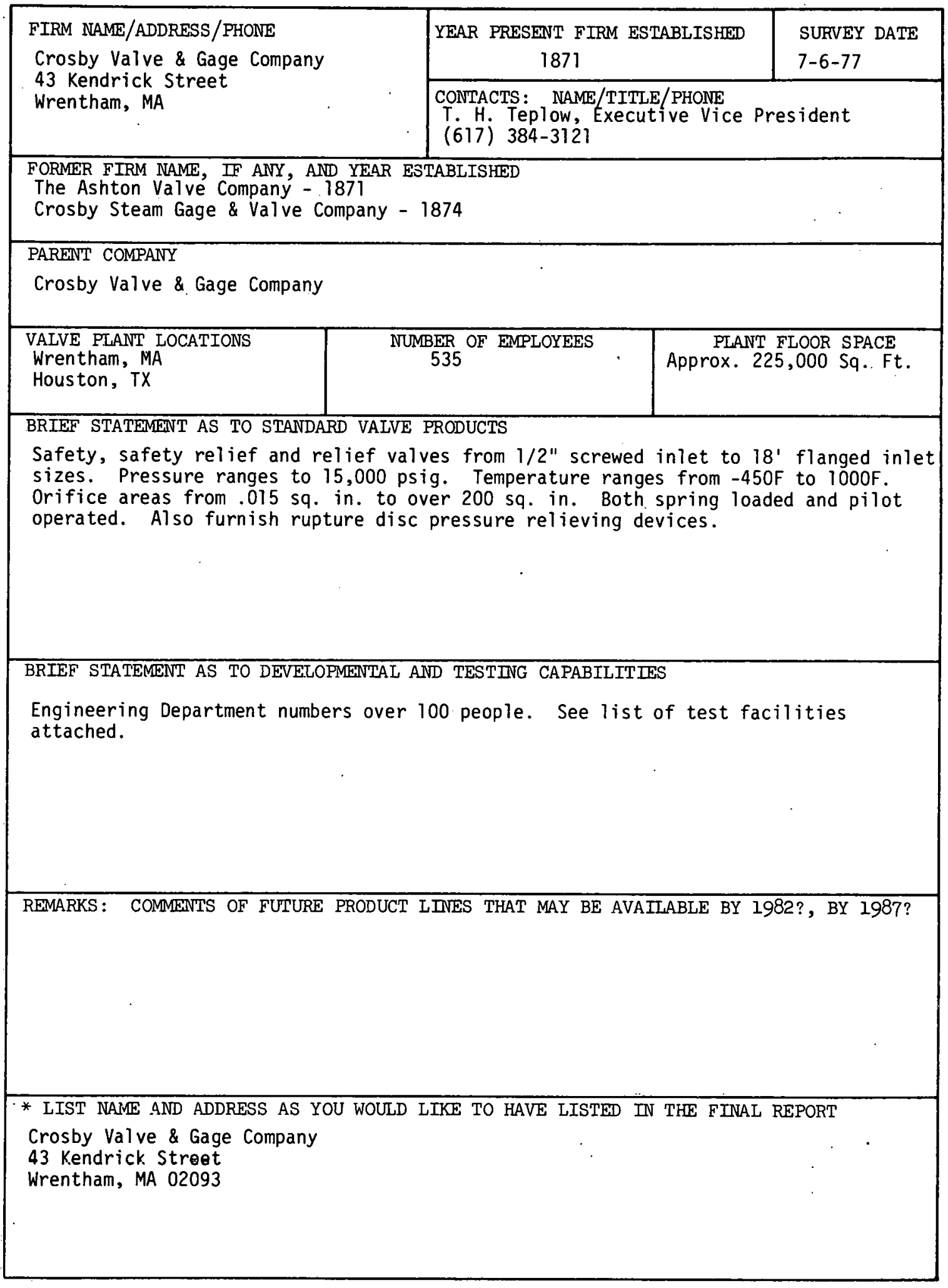




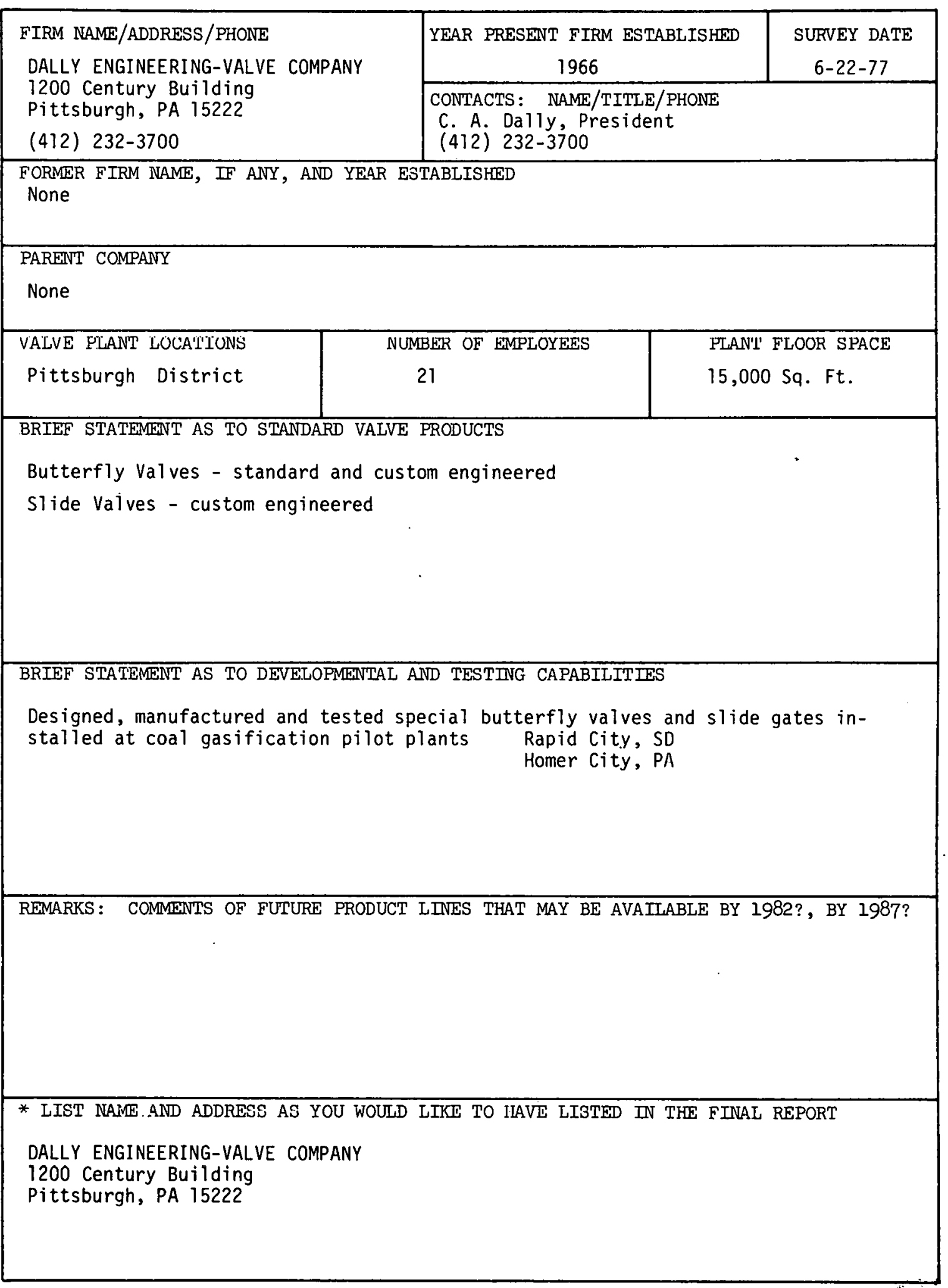




\begin{tabular}{|c|c|c|}
\hline \multirow{2}{*}{$\begin{array}{l}\text { FIRM NAME/ADDRESS/PHONE } \\
\text { DeZURIK, A Unit of General Signal } \\
\text { Sartell, MN } 56377 \\
\text { (612) } 251-0221\end{array}$} & $\begin{array}{l}\text { YEAR PRESENT FIRM ESTABLISHED } \\
1928\end{array}$ & $\begin{array}{l}\text { SURVEY DATE } \\
6-30-77\end{array}$ \\
\hline & \multicolumn{2}{|c|}{$\begin{array}{l}\text { CONTACTS: NAME/TITLE/PHONE } \\
\text { Glenn Bowman - Vice President - Sales } \\
\text { H. Dean Olson - Industrial Sales Manager }\end{array}$} \\
\hline \multicolumn{3}{|c|}{$\begin{array}{l}\text { FORMER FIRM NAME, IF ANY, AND YEAR ESTABLISHED } \\
\text { DeZURIK Shower Company } \\
\text { DeZURIK Corporation }\end{array}$} \\
\hline \multicolumn{3}{|l|}{$\begin{array}{l}\text { General Signal } \\
\text { High Ridge Park, Stamford, CT } 06904\end{array}$} \\
\hline \begin{tabular}{l|l} 
VALVE PLANT LOCATIONS & \\
Sarteli, MN & \\
McMinnville,TN & \\
LaGrange,GA & \\
\end{tabular} & \begin{tabular}{l|l} 
BER OF EMPLOYEES & PLAI \\
200 (Total) & $\begin{array}{l}\text { Sartell } \\
\text { McMinnvi } \\
\text { LaGrange }\end{array}$ \\
\end{tabular} & $\begin{array}{l}\text { LOOR SPACE } \\
, 000 \mathrm{Sq} . \mathrm{Ft} . \\
178,000 \mathrm{Sq} . \mathrm{Ft} \\
, 000 \mathrm{Sq} . \mathrm{Ft} .\end{array}$ \\
\hline \multicolumn{3}{|c|}{$\begin{array}{l}\text { BRIEF STATEMENT AS TO STANDARD VALVE PRODUCTS } \\
\text { The original DeZURIK valve, the eccentric plug valve is still the major line with } \\
\text { applications in all process industries and utility markets. Bonnetless knife gate } \\
\text { valves are primarily intended for slurry and other abrasive applications. Two } \\
\text { butterfly lines, a resilient seated and a teflon seated design for abrasive and high } \\
\text { pressure applications. Finally, the only fully flanged segmented V-ball valve on } \\
\text { the market for applications to } 1000^{\circ} \mathrm{F} \text { and pressures to } 740 \text { psi. }\end{array}$} \\
\hline \multicolumn{3}{|c|}{$\begin{array}{l}\text { BRIEF STATEMENT AS TO DEVELOPMENTAL AND TESTING CAPABILITIES } \\
\text { DeZURIK engineering product development consists of four development teams of three } \\
\text { engineers each that specialize in various valve styles.. The laboratory for research } \\
\text { and development includes test facilities for pumping up to } 100,000 \text { GPM. Valve } \\
\text { pressure drop capabilities, capacity, noise suppression, application condition, } \\
\text { and cycle testing are some of the common types of activities carried on. }\end{array}$} \\
\hline \multicolumn{3}{|c|}{$\begin{array}{l}\text { REMARKS: COMMENTS OF FUTURE PRODUCT LINES THAT MAY BE AVAILABLE BY 1982?, BY 1987? } \\
\text { DeZURIK has grown at the rate of } 15 \% \text { per year for more than a decade adding new } \\
\text { products almost yearly. Higher pressure and temperature capabilities are an in- } \\
\text { tegral part of this expansion story. Abrasive slurries as found in mining and wet } \\
\text { scrubber installations are DeZURIK specialties. 1500\# applications should be } \\
\text { realistic for DeZURIK by } 1982 \text {. }\end{array}$} \\
\hline \multicolumn{3}{|c|}{$\begin{array}{l}\text { * LIST NAME AND ADDRESS AS YOU WOULD LIKE TO HAVE LISTED IN THE FINAL REPORT } \\
\text { DeZURIK, A Unit of General Signal } \\
\text { Sartel1, MN } 56.377\end{array}$} \\
\hline
\end{tabular}


FIRM NAME/ADD̈RESS/PHONE

Dresser Industrial Valve \& Inst. Div.

250 East Main Street

Stratford, Conn. 06497

(203) $378-8281$
YEAR PRE'SET'I' F'TRM E'S'LABLISHE'W

1964 (Dresser IVI Div.)

CONTACTS: NAME/TITLE/PHONE

C. E. Muller, Vice President-Marketing. 203-378-8281

FOR:Eה FIE:! ILYE, IF ANY, AIND YEAR ESTABLISHED

Manning, Maxwell \& Moore - 1880

Dewrance \& Co. - 1844

PARFiT COMPHAI

Dresser Industries, Inc.

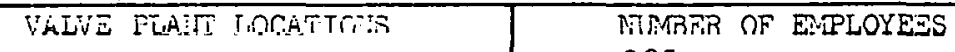

Alexandria, Louisiana 785

Skelmersdale, England

500

PTANTT FLOOR SPACE

270,000 sq. ft.

BRIEF STATEMIT AS TO STANDARD VALVE PRODUCTS

Forged and cast steel globe, gate and checks, safety and safety relief valves.

Media operated globe and gate valves.

BRIEF STATEMENT AS TO DEVELOPMENTAL AND TESTING CAPABILITIES

Design Departments at both locations carry out continual developmental and test programs, mainly for fossil and nuclear power plant applications. Testing

capabilities include normal hydro test and steam test at Alexandria.

REMARKS: COMMENTS OF FUTURE PRODUCT LINES THAT MAY BE AVAILABLE BY 1982?, BY 1987?

Extend range of existing lines.

Develop specialized products.

* LIST NAME AND ADDRESS AS YOU WOULD LIKE TO HAVE LISTED IN THE FINAL REPORT 


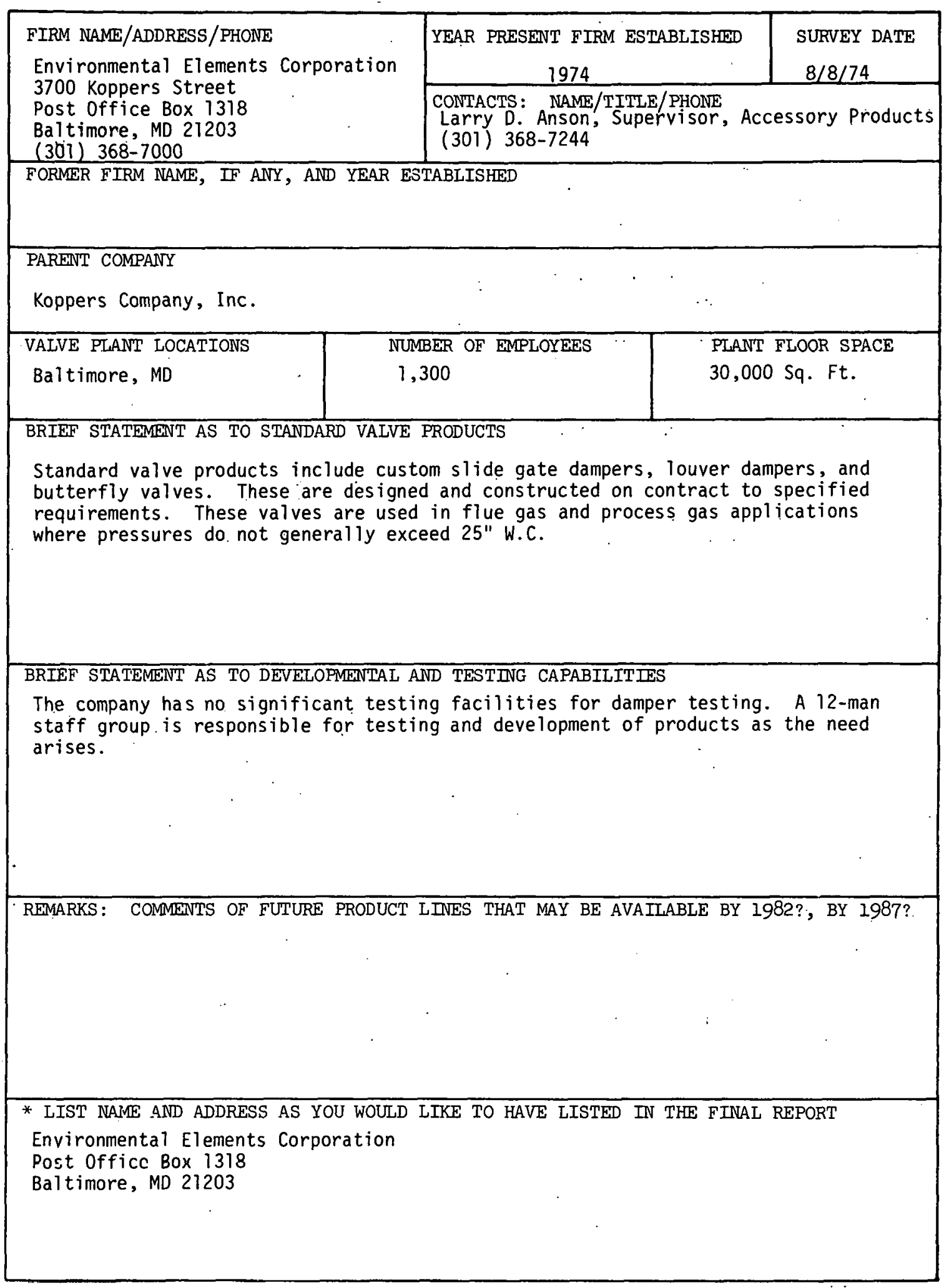




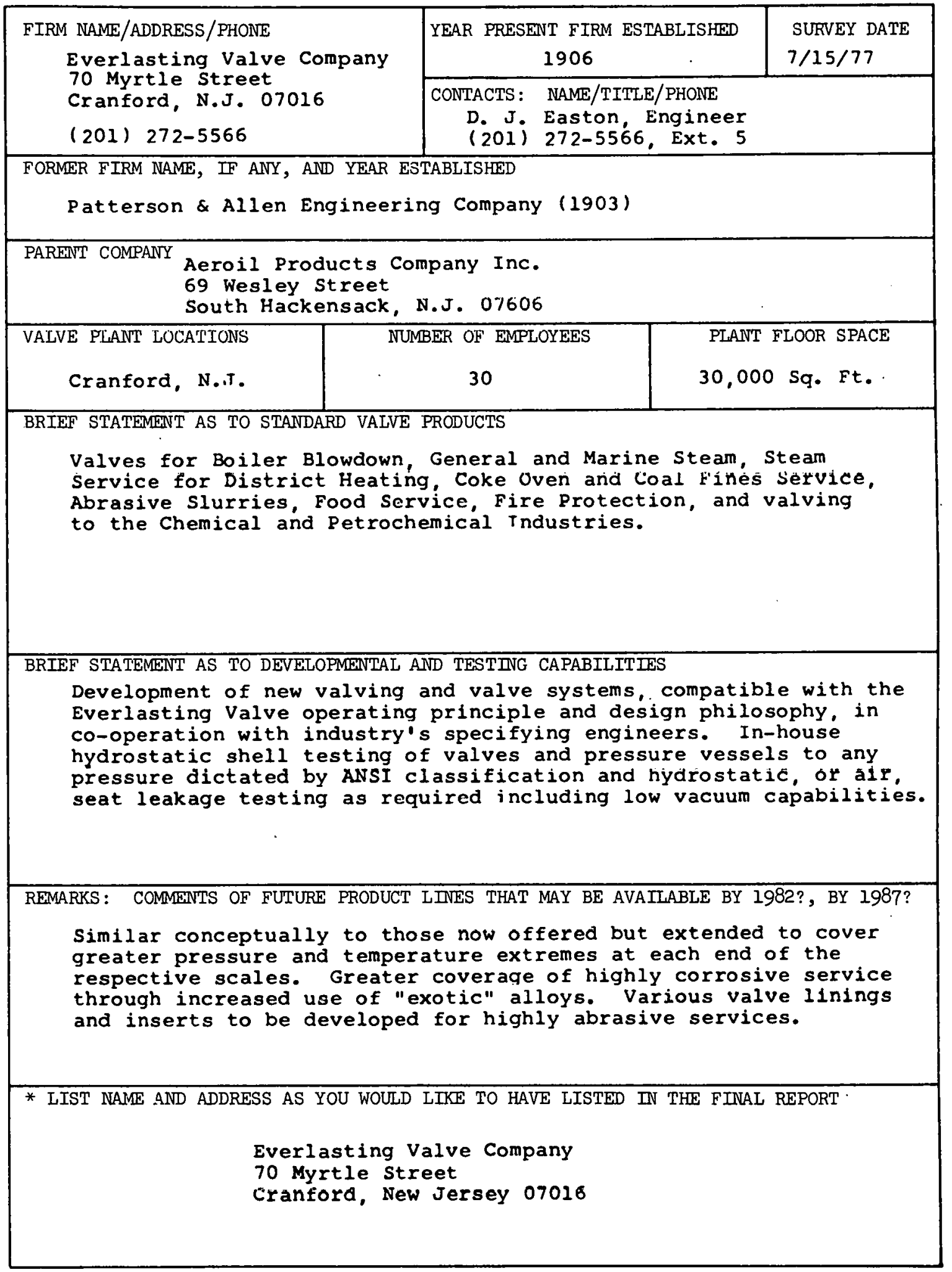




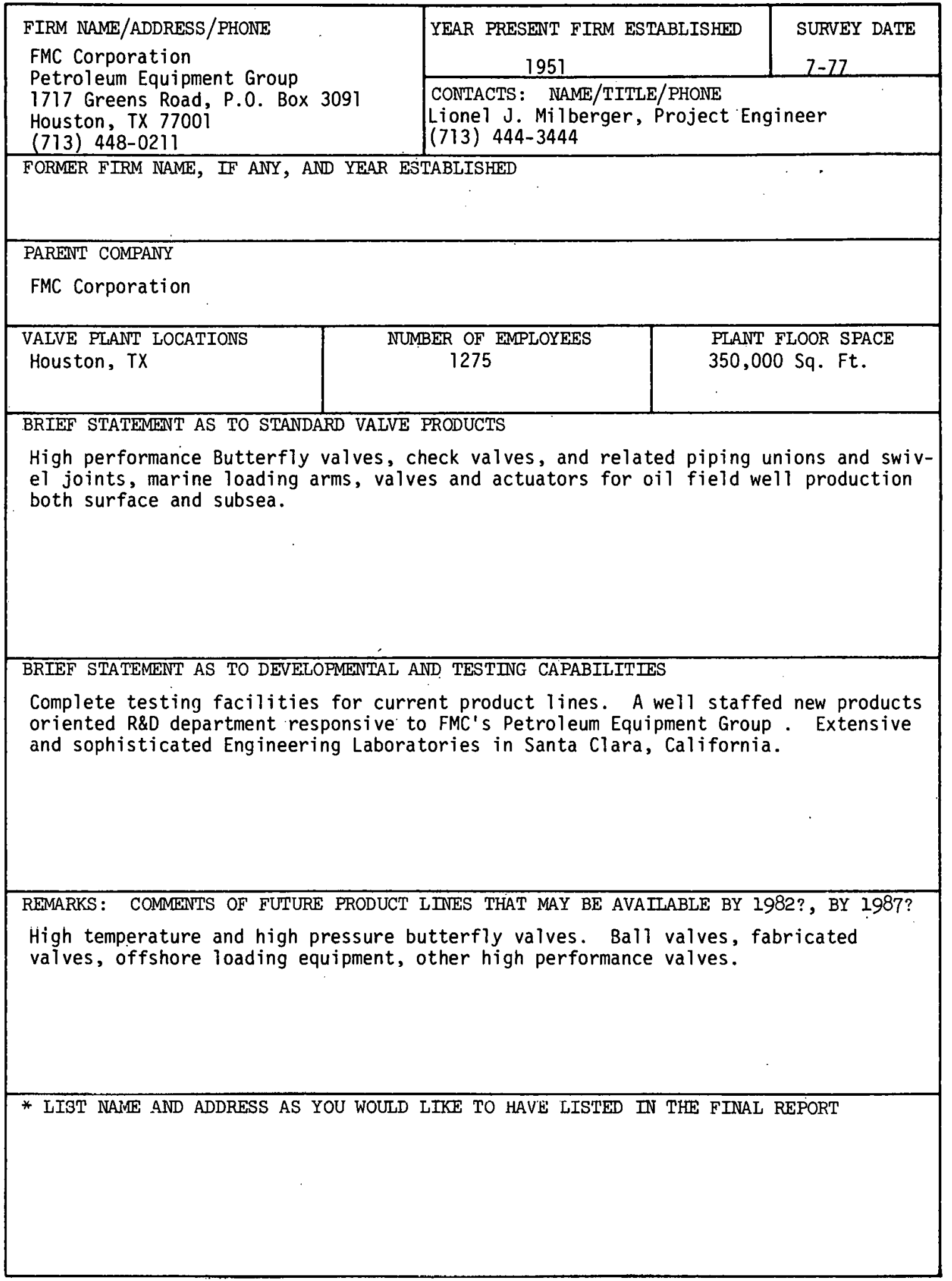




\begin{tabular}{|c|c|c|}
\hline \multirow{2}{*}{$\begin{array}{l}\text { FIRM NAME/ADDRESS/PHONE } \\
\text { Fabri-Val ve } \\
\text { P. 0. BOX } 4367 \\
\text { Portland, OR } 97208 \\
\text { (503) } 284-1131\end{array}$} & $\begin{array}{c}\text { YEAR PRESENT FIRM ESTABLISHED. } \\
1948\end{array}$ & $\begin{array}{l}\text { SURVEY DATE } \\
7 / 15 / 77\end{array}$ \\
\hline & \multicolumn{2}{|l|}{$\begin{array}{l}\text { CONTACTS: NAME/TITLE/PHONE } \\
\text { Day Tooley } \\
\text { Market Manager }(504) 284-113 \text { ? }\end{array}$} \\
\hline \multicolumn{3}{|c|}{$\begin{array}{l}\text { FORMER FIRM NAME, IF ANY, AND YEAR ESTABLISHED } \\
\text { Albina Engine \& Machine }\end{array}$} \\
\hline \multicolumn{3}{|l|}{$\begin{array}{l}\text { PARENT COMPANY } \\
\text { Dillingham Corporation }\end{array}$} \\
\hline \multicolumn{3}{|l|}{$\begin{array}{l}\text { VALVE PLANT LOCATIONS } \\
\text { Portland, Oregon } \\
\text { Amory, Mississippi }\end{array}$} \\
\hline \multicolumn{3}{|c|}{$\begin{array}{l}\text { BRIEF 3TATEMENT AS TO STANDARD VALVE PRODUCTS } \\
\text { Fabricated wedge gate, knife gate, check and butterfly valves from } 2 \text { " to } 120^{\prime \prime} \text { size. } \\
\text { Wide range of materials available since valves are fabricated from wrought materials }\end{array}$} \\
\hline \multicolumn{3}{|c|}{$\begin{array}{l}\text { BRIEF STATEMENT AS TO DEVETOPMENTAL AND TESTING CAPABILITIES } \\
\text { Flow loop, stress analysis laboratory available to verify new and existing designs. }\end{array}$} \\
\hline \multicolumn{3}{|c|}{$\begin{array}{l}\text { RDMARKS: COMMENTS OF FUTURE PRODUCT LINES THAT MAY BE AVAIIABLE BY 1982?, BY } 1987 ? \\
\text { Trend in industries we serve is: } \\
\text { (1) Toward higher pressures } \\
\text { (2) Increasing valve size }\end{array}$} \\
\hline \multicolumn{3}{|c|}{$\begin{array}{l}\text { * LIST NAME AND ADDRESS AS YOU WOULD LIKE TO HAVE LISTED IN THE FINAL REPORT } \\
\text { Fabri-Valve } \\
\text { P. 0. Box } 4367 \\
\text { Portiand, Oregon } 97208\end{array}$} \\
\hline
\end{tabular}




\begin{tabular}{|c|c|c|}
\hline \multirow{2}{*}{$\begin{array}{l}\text { FIRM NAME/ADDRESS/PHONE } \\
\text { Fairchild Stratos Division } \\
1800 \text { Rosecrans Avenue } \\
\text { Manhattan Beach, CA } 90266 \\
\text { (213) 675-9111 }\end{array}$} & $\begin{array}{l}\text { YEAR PRESENT FIRM ESTABLISHED } \\
\quad 1954\end{array}$ & $\begin{array}{l}\text { SURVEY DATE } \\
\text { Nov. 2, } 1977\end{array}$ \\
\hline & \multicolumn{2}{|c|}{$\begin{array}{l}\text { CONTACTS: NAME/TITILE/PHONE } \\
\text { Matthew Miller, Product Mgr., Ext. } 368\end{array}$} \\
\hline \multicolumn{3}{|c|}{$\begin{array}{l}\text { FORMER FIRM NAME, IF ANY, AND YEAR ESTABLISHED } \\
\text {-- }\end{array}$} \\
\hline \multicolumn{2}{|l|}{ Fairchild Industries, Inc. } & \\
\hline $\begin{array}{l}\text { VALVE PLANT LOCATIONS } \\
1800 \text { Rosecrans Avenue } \\
\text { Manhattan Beach, CA } 90266\end{array}$ & \begin{tabular}{l|l} 
BER OF EMPLOYEES & PLAI \\
approximately & $:$
\end{tabular} & FLOOR SPACE \\
\hline \multicolumn{3}{|c|}{$\begin{array}{l}\text { BRIEF STATEMENT AS TO STANDARD VALVE PRODUCTS } \\
\text { Many years in aerospace industry making valves and disconnects. Recent contracts } \\
\text { for design and fabrication of large high-vacuum valves and large valves to be used } \\
\text { in coal gasification processes. }\end{array}$} \\
\hline \multicolumn{3}{|c|}{$\begin{array}{l}\text { BRIEF STATEMENT AS TO DEVELOPMENTAL AND TESTING CAPABILITIES } \\
\text { Extensive facilities for high and low pressure gas valves. Pressurization and } \\
\text { instrumentation capability suitable for all types of industrial valves. A multi- } \\
\text { million dollar, large valve fabrication facility is being added to the existing } \\
\text { Fairchild Stratos Division plant. }\end{array}$} \\
\hline \multicolumn{3}{|c|}{$\begin{array}{l}\text { REMARKS: COMMENTS OF FUTURE PRODUCT LINES THAT MAY BE AVAILABLE BY 1982?, BY } 1987 \text { ? } \\
\text { Future valve product lines will be centered around hostile environment block valves, } \\
\text { pressure let-down valves and lock-hopper valves. High vacuum valves for the nuclear } \\
\text { industry will also be manufactured. }\end{array}$} \\
\hline $\begin{array}{l}\text { * LIST NAME AND ADDRESS AS } \\
\text { Fairchild Stratos Division } \\
1800 \text { Rosecrans Avenue } \\
\text { Manhattan Beach, CA } 90266 \\
\text { (213) } 675-9111\end{array}$ & LIKE TO HAVE LISTED. IN THE FINA & REPORT \\
\hline
\end{tabular}




\begin{tabular}{|c|c|c|}
\hline \multirow{2}{*}{$\begin{array}{l}\text { FIRM NAME/ADDREDS/ MIONE } \\
\text { Fetterolf Corporation } \\
\text { P. O. Box } 156 \\
\text { Fairview Village, PA } 19409\end{array}$} & $\begin{array}{l}\text { YTAR TRECENT PIIM ESTABLIEHEED } \\
1968\end{array}$ & $\begin{array}{l}\text { SURVEY D } \Lambda \text { TE } \\
7 / 29 / 77\end{array}$ \\
\hline & \multicolumn{2}{|c|}{$\begin{array}{l}\text { CONTACTS: NAME/TITLE/PHONE } \\
\text { A. M. Ritter, Vice-President, (215) 539-7055 }\end{array}$} \\
\hline \multicolumn{3}{|c|}{ FORMER FIRM NAME, IF ANY, AND YEAR ESTABLISHED } \\
\hline \multicolumn{3}{|l|}{ PARENT COMPANY } \\
\hline \multicolumn{3}{|l|}{$\begin{array}{l}\text { VALVE PLANT LOCATIONS } \\
\text { Royersford, PA } \\
\text { Fairview Village, PA }\end{array}$} \\
\hline \multicolumn{3}{|c|}{$\begin{array}{l}\text { Valve products that are currently standard are continuations of specialty } \\
\text { valves developed and fabricated for specific applicational needs. All are } \\
\text { of Ram-Seal patented design for use on slurry or other aggressive fluid media } \\
\text { applications. All are custom built. }\end{array}$} \\
\hline \multicolumn{3}{|c|}{$\begin{array}{l}\text { BRIEF STATEMENT AS TO DEVELOPMENTAL AND TESTING CAPABILITIES } \\
\text { Fetterolf Corporation Development Group has high capability for problem analysis } \\
\text { and conceptual development of unique valve products to satisfy long-standing } \\
\text { needs. Current projects for ERDA are typical. }\end{array}$} \\
\hline \multicolumn{3}{|c|}{$\begin{array}{l}\text { REMARKS: COMMENTS OF FUTURE PRODUCT LINES THAT MAY BE AVAILABLE BY 1982?, BY } 1987 ? \\
\text { Valves of many configurations for hosti le mèdia. } \\
\text { Large blind flanges and valves } \\
\text { Knife gate }\end{array}$} \\
\hline \multicolumn{3}{|c|}{$\begin{array}{l}\text { * LIST NAME AND ADDRESS AS YOU WOULD LIKE TO HAVE LISTED IN THE FINAL REPORT } \\
\text { Fetterolf Corporation } \\
\text { P. 0. Box } 156 \\
\text { Fairview Village, PA } 19409\end{array}$} \\
\hline
\end{tabular}




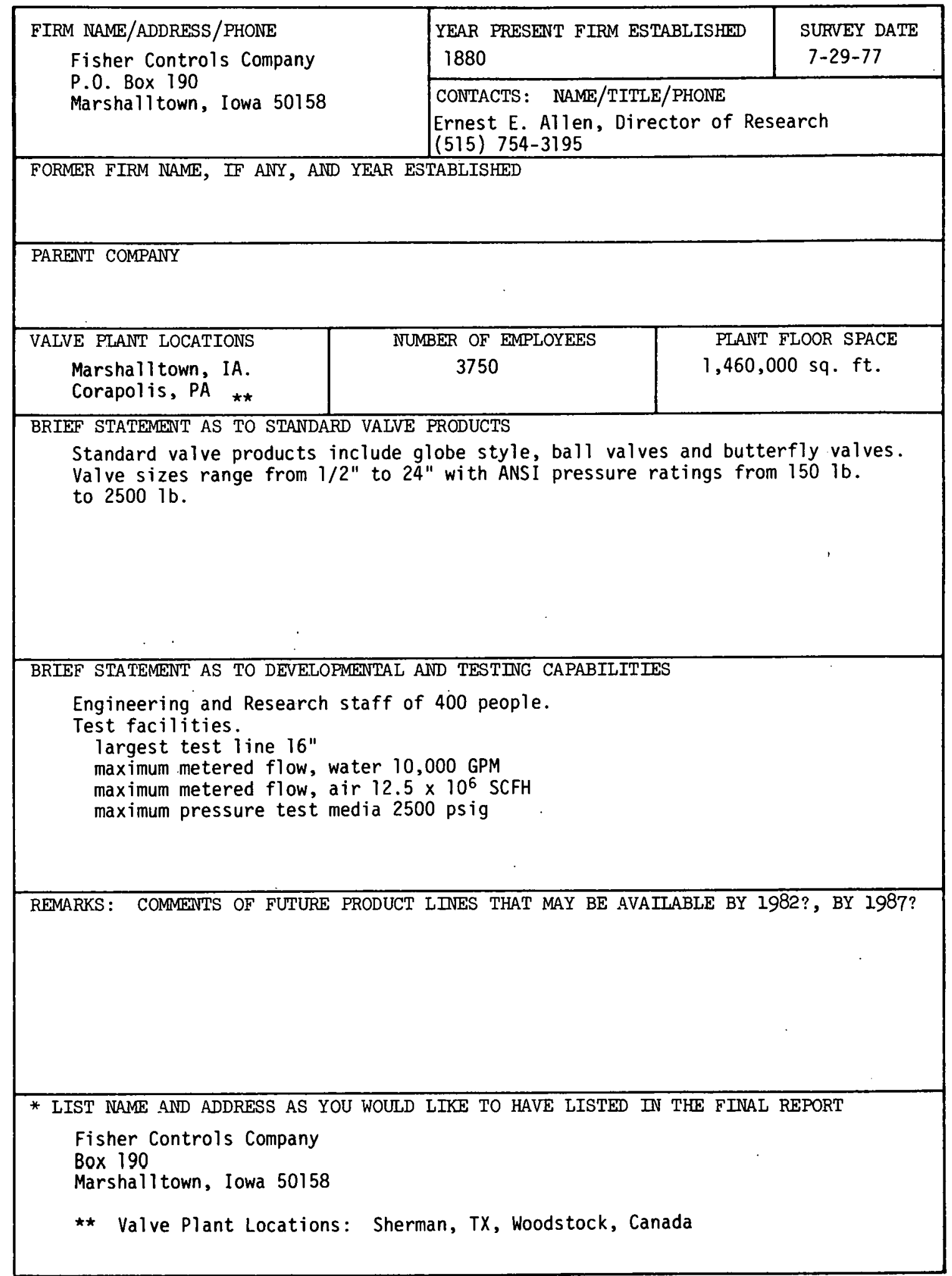




\begin{tabular}{|c|c|c|}
\hline \multirow{2}{*}{$\begin{array}{l}\text { FIRM NAME/ADDRESS/PHONE } \\
\text { Fox Valve Development Co., Inc. } \\
2 \text { Great Meadow Lane } \\
\text { Hanover, New Jersey } 07936\end{array}$} & $\begin{array}{l}\text { YEAR PRESENT FIRM ESTABLISHED } \\
1960\end{array}$ & $\begin{array}{l}\text { SURVEY DATE } \\
6-22-77\end{array}$ \\
\hline & \multicolumn{2}{|c|}{$\begin{array}{l}\text { CONTACTS: } \text { NAME/TITLE/PHONE } \\
\text { Zola Fox, President, (201) 887-7474 }\end{array}$} \\
\hline \multicolumn{3}{|c|}{ FORMER FIRM NAME, IF ANY, AND YEAR ESTABLISHED } \\
\hline \multicolumn{3}{|l|}{ PAREINT COMPANY } \\
\hline \begin{tabular}{c|c|c} 
VALVE PLANT LOCATIONS & NUT \\
1 &
\end{tabular} & \begin{tabular}{l|r} 
BER OF EMPLOYEES & PT:AN \\
12 &.
\end{tabular} & $\begin{array}{l}\text { TOOR SPACE } \\
000\end{array}$ \\
\hline \multicolumn{3}{|c|}{$\begin{array}{l}\text { BRIEF STATEMENT AS TO STANDARD VALVE PRODUCTS } \\
\text { Venturi T̈ype Throttiling \& Shut-0ff Valves.: } \\
\left.\text { High Temperature ( } 2000^{\circ} \mathrm{F}\right) \text { Shut-0ff, Throttle \& Relief Valves } \\
\text { Rapid Response, High Pressure Valves (.010 MS \& } 10,000 \text { PSI Typ.) Pressures } \\
\text { to } 25,000 \text { PSI }\end{array}$} \\
\hline \multicolumn{3}{|c|}{$\begin{array}{l}\text { BRIEF STATEMENT AS TO DEVELOPMENTAL AND TESTING CAPABILITIES } \\
\text { Two water flow test stands; } \mathrm{H}_{\mathrm{e}}, \mathrm{N}_{2} \text { to } 3500 \text { PSI pressure test, life cycle test } \\
\qquad, \because\end{array}$} \\
\hline \multicolumn{3}{|c|}{$\begin{array}{l}\text { REMARKS: COMMENTS OF FUTURE PRODUCT LINES THAT MAY BE AVAILABLE BY 1982?, BY 1987? } \\
\text { Continued development of existing lines including binary type (digital) valves }\end{array}$} \\
\hline $\begin{array}{l}\text { * IIST NAME AND ADDRESS AS YOU WOULD } \\
\text { Fox Valve Development Co., Inc. } \\
2 \text { Great Meadow Lane } \\
\text { Hanover, New Jersey } 07936\end{array}$ & $\begin{array}{c}\text { LIKE TO HAVE LISTED IN THE FINA } \\
\ddots\end{array}$ & EPORT \\
\hline
\end{tabular}




\begin{tabular}{|c|c|c|c|}
\hline \multirow{2}{*}{$\begin{array}{l}\text { FIRM NAME/ADDRESS/PHONE } \\
\text { Gas Machinery Division } \\
\text { Modern Equipment Co. } \\
336 \text { South Spring Street } \\
\text { Port Washington, WI } 53074 \\
\text { (414) } 284-3441\end{array}$} & \multicolumn{2}{|c|}{$\begin{array}{c}\text { YEAR PRESENT FIRM ESTABLISHED } \\
1902\end{array}$} & $\begin{array}{l}\text { SURVEY DATE } \\
7-28-77\end{array}$ \\
\hline & \multicolumn{3}{|c|}{$\begin{array}{l}\text { CONTACTS: NAME/TITLE/PHONE } \\
\text { M. R. Bruck, Mgr. Special Products \& Services }\end{array}$} \\
\hline \multicolumn{4}{|c|}{$\begin{array}{l}\text { FORMER FIRM NAME, IF ANY, AND YEAR ESTABLISHED } \\
\text { Gas Machinery Company, } 1902\end{array}$} \\
\hline \multicolumn{2}{|c|}{ A) co Standard, Valley Forge, PA } & & \\
\hline \multicolumn{4}{|c|}{\begin{tabular}{l|c|c} 
VALVE PLANT LOCATIONS & NUMBER OF EMPLOYEES & PLANT FLOOR SPACE \\
Port Washington, WI & 200 & $115,373 \mathrm{Sq} . \mathrm{Ft}$.
\end{tabular}} \\
\hline \multicolumn{4}{|c|}{$\begin{array}{l}\text { BRIEF STATEMENT AS TO STANDARD VALVE PRODUCTS } \\
\text { A11 Iron Double Disc Gate Valves } \\
\text { Size: 6"-60" } \\
\text { Operation: Handwheel, Hyd. Cyl. or Motor } \\
\text { Service: Air or Gas } \\
\text { Low Pressure, } 60 \text { psi maximum } \\
\text { Temperature: } 1400^{\circ} \mathrm{F} \text { maximum } \\
\text { A11 Iron Blast Gate Valves } \\
\text { Size: 1"-48" } \\
\text { Operation: Handwheel, Hyd. Cyl. or Motor } \\
\text { Service: Air, Low Pressure, } 3 \text { psi max., Temp: } 1000^{\circ} \mathrm{Fmax.}\end{array}$} \\
\hline \multicolumn{4}{|c|}{$\begin{array}{l}\text { BRIEF STATEMENT AS TO DEVELOPMENTAL AND TESTING CAPABILITIES } \\
\text { We employ adequate engineering personnel and field engineers for the development } \\
\text { and testing of our special products. A test Stand is available in our shop. } \\
\text { We pressure test and operate every valve we manufacture prior to shipment. }\end{array}$} \\
\hline \multicolumn{4}{|c|}{$\begin{array}{l}\text { REMARKS: COMMENTS OF FUTURE PRODUCT LINES THAT MAY BE AVAIIABLE BY 1982?, BY } 1987 ? \\
\text { Currently we do not have any new valve products planned. Special designs are } \\
\text { developed for customer application. }\end{array}$} \\
\hline \multicolumn{4}{|c|}{$\begin{array}{l}\text { * LIST NAME AND ADDRESS AS YOU WOULD LIKE TO HAVE LISTED IN THE FINAL REPORT } \\
\text { Gas Machinery Div. } \\
\text { Modern Equipment Co. } \\
336 \text { South Spring St. R. Bruck } \\
\text { Port Washington, WI } 53074\end{array}$} \\
\hline
\end{tabular}




\begin{tabular}{|c|c|c|}
\hline \multirow{2}{*}{$\begin{array}{l}\text { FTRM NAMF/ADNRFSS/PHONF } \\
\text { Geillo } \\
\text { The General Machine Co. of N.J. } \\
55 \text { Evergreen Avenue } \\
\text { Newark, NJ } 07114 \\
\text { (201) } 242-7405\end{array}$} & $\begin{array}{l}\text { YEAR PRESENT FIRM ESTABLISHED } \\
1945\end{array}$ & $\begin{array}{l}\text { SURVEY DATE } \\
7 / 6 / 77\end{array}$ \\
\hline & \multicolumn{2}{|c|}{$\begin{array}{l}\text { CONTACIS: NAME/TITLE/PHONE } \\
\text { G. R. Sweitzer - General Manager - } \\
(201) \text { 242-7405 }\end{array}$} \\
\hline \multicolumn{3}{|c|}{$\begin{array}{l}\text { FORMER FIRM NAME, IF ANY, AND YEAR ESTABLISHED } \\
\text { None }\end{array}$} \\
\hline \multicolumn{3}{|l|}{$\begin{array}{l}\text { PARENT COMPANY } \\
\text { None }\end{array}$} \\
\hline \begin{tabular}{l|l} 
VALVE PLANT LOCATIONS & \\
Newark, NJ &
\end{tabular} & \begin{tabular}{c|r}
41 & PL EMN \\
41 & 15
\end{tabular} & $\begin{array}{l}\text { LOOR SPACE } \\
\text { sq. rt. }\end{array}$ \\
\hline \multicolumn{3}{|c|}{ BRIEF STATEMENT AS TO STANDARD VALVE PRODUCTS } \\
\hline \multicolumn{3}{|c|}{$\begin{array}{l}\text { NOTE: DUST-TITE spherical valves for solids, slurries and contaminated liquids } \\
\text { sizes } 3^{\prime \prime} \text { to } 24 " \text {. } \\
\text { Special valves to } 1800 F, 50 \text { psi, differential pressure. Features include } \\
\text { jacketed, special alloys, platings, coatings, and synthetics. }\end{array}$} \\
\hline \multicolumn{3}{|c|}{$\begin{array}{c}\text { BRIEF STATEMENT AS TO DEVELOPMENTAL AND TESTING CAPABILITIES } \\
\text { See Letter Information }\end{array}$} \\
\hline \multicolumn{3}{|c|}{ NOTE: Facilities for pressure and temperature testing } \\
\hline \multicolumn{3}{|c|}{ 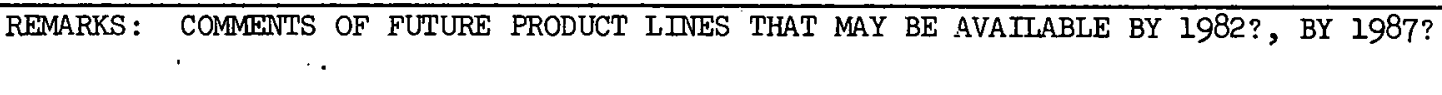 } \\
\hline \multicolumn{3}{|c|}{$\begin{array}{l}\text { * LIST NAME AND ADDRESS AS YOU WOULD LIKE TO HAVE LISTED IN THE FINAL REPORT } \\
\text { Gemco } \\
\text { The General Machine Co. of NJ } \\
55 \text { Evergreen Avenue } \\
\text { Newark. New Jersey } 07114 \\
\text { Attn: Mr. G. R. Sweitzer - General Manager }\end{array}$} \\
\hline
\end{tabular}




\begin{tabular}{|c|c|c|}
\hline \multirow{2}{*}{$\begin{array}{l}\text { FIRM NAME/ADDRESS/PHONE } \\
\text { Gould Inc. } \\
\text { Valve and Fittings Div. } \\
6300 \text { W. Howard St. } \\
\text { Chicago, IL } 60648 \\
\text { A/C } 312 / 967-4500\end{array}$} & $\begin{array}{c}\text { YEAR PRESEINT FIRM ESTABLISHED } \\
1869\end{array}$ & $\begin{array}{l}\text { SURVEY DATE } \\
7-6-77\end{array}$ \\
\hline & \multicolumn{2}{|c|}{$\begin{array}{l}\text { CONTACTS: NAME/TITLE/PHONE } \\
\text { Carl Sutherland - Manager } \\
\text { Process Control Sales A/C 312/967-4606 }\end{array}$} \\
\hline \multicolumn{3}{|c|}{$\begin{array}{l}\text { FORMER FIRM NAME, IF ANY, AND YEAR ESTABLISHED } \\
\text { Imperial-Eastman Corporation } \\
\text { Established: } 1901\end{array}$} \\
\hline \multicolumn{3}{|c|}{$\begin{array}{l}\text { PAREINT COMPANY } \\
\text { Gould Inc. (See enclosed Annual Report) }\end{array}$} \\
\hline $\begin{array}{l}\text { VALVE PLANT LOCATIONS } \\
6300 \text { W. Howard St. } \\
7401 \text { N. Croname Rd. } \\
\text { Chicago, IL } 60648\end{array}$ & \begin{tabular}{|r|r} 
BER OF EMPLOYEES & PLAN' \\
990 & 300 \\
\end{tabular} & $\begin{array}{l}\text { LOOR SPACE } \\
\text { sq. ft. }\end{array}$ \\
\hline \multicolumn{3}{|c|}{$\begin{array}{l}\text { BRIEF STATEMENT AS TO STANDARD VALVE PRODUCTS (See enclosed catalogues) } \\
\text { Instrument BY-Pass Manifolds (1/2" Fem. Pipe Max.) (6,500 psi Max.) } \\
\text { One (1), Three ( } 3 \text { ) and Five (5) Valve Models } \\
\text { Brass, Carbon Steel, } 316 \mathrm{SS} \text {, Monel, Inconel, Alloy } 20 \text { and Hastelloy "C". } \\
\text { Temp. Range: -600F to } 1200^{\circ} \mathrm{F} \\
\text { Instrument Hand Valves ( } 1 \text { " Fem. Pipe Max.) }(10,000 \text { psi Max) } \\
\text { Carbon and } 316 \mathrm{SS} \\
\text { Memp. Range: - } 60^{\circ} \mathrm{F} \text { to } 1200^{\circ} \mathrm{F} \\
\text { Manufactured to: API, ANSI, B31.1, ASME Sec. III Nuclear Class } 1,2 \& 3\end{array}$} \\
\hline \multicolumn{3}{|c|}{$\begin{array}{l}\text { BRIEF STATEMENT AS TO DEVETOPMENTAL AND TESTING CAPABILITIES } \\
\text { Have extensive development and testing capabilities within Gould Inc. We here } \\
\text { at the Valve and Fittings Div. work closely with The Materials Research Laboratory, } \\
\text { Cleveland, Ohio. }\end{array}$} \\
\hline \multicolumn{3}{|c|}{$\begin{array}{l}\text { REMARKS: COMMENTS OF FUTURE PRODUCT LINES THAT MAY BE AVAILABLE BY 1982?, BY 1987? } \\
\text { It is our intention to expand our size range to "2" by } 1982 \text {. Our concentration } \\
\text { will be in the area of Isolation and/or Root Valves for Hi-Pressure/Hi-Temperature/ } \\
\text { Corrossive Service. }\end{array}$} \\
\hline \multicolumn{3}{|c|}{$\begin{array}{l}\text { * LIGT NAMT AND ADDRRS3 A3 YOU WOULD LIKE TO HAVE LISTED IN THE F INAL REPORT } \\
\text { Gould Inc. } \\
\text { Valve and Fittings Division } \\
6300 \text { W. Howard St. } \\
\text { Chicago, IL } 60648\end{array}$} \\
\hline
\end{tabular}




\begin{tabular}{|c|c|c|}
\hline \multirow{2}{*}{$\begin{array}{l}\text { FIRM NAME/ADDRESS/PHONE } \\
\text { Hall iburton Services } \\
\text { Drawer } 1431 \\
\text { Duncan, Oklahoma } 73533 \\
\text { Stephens County } \\
\text { Phone: (405) } 251-3760\end{array}$} & $\begin{array}{c}\text { YEAR PRESENT FIRM ESTABLISHED } \\
9-15-67\end{array}$ & $\begin{array}{l}\text { SURVEY DATE } \\
7-11-77\end{array}$ \\
\hline & \multicolumn{2}{|c|}{$\begin{array}{l}\text { CONTACTS: NAME/TITLE/PHONE } \\
\text { Leonard Leon, Exec. V.P. (405) } 251-3165 \\
\text { Bobb Diggs Brown, VP }(405) 251-3369\end{array}$} \\
\hline \multicolumn{3}{|c|}{$\begin{array}{l}\text { FORMER FIRM NAME, IF ANY, AND YEAR ESTABLISHED } \\
\text { Hall iburton } 0 \text { il Well Cementing Company } \\
\text { Incorporated in } 1924\end{array}$} \\
\hline \multicolumn{3}{|l|}{$\begin{array}{l}\text { PARENT COMPANY } \\
\text { Hall i burton Company } \\
3211 \text { Southiand Center } \\
\text { Dallas. Texas } 75201\end{array}$} \\
\hline $\begin{array}{l}\text { Dallas. Texas } 75201 \\
\text { VALVE PLANT LOCATIONS } \\
\text { P. O. Drawer } 1431 \\
\text { Duncan, Oklahoma } 73533\end{array}$ & \begin{tabular}{l|l} 
BER OF EMPLOYEES & PLAI \\
2200 & 600
\end{tabular} & $\begin{array}{l}\text { LOOR SPACE } \\
\text { sq. ft. }\end{array}$ \\
\hline \multicolumn{3}{|c|}{ BRIEF STATEMENT AS TO STANDARD VALVE PRODUCTS } \\
\hline \multicolumn{3}{|c|}{$\begin{array}{l}\text { Halliburton faced a need for handling, manifolding, and controlling some of the } \\
\text { highest sustained pressures ever attempted. There were none available commercially } \\
\text { to meet our specifications - so Hall iburton designed, developed, and manufactured } \\
\text { the Halliburton Lo Torc Plug Valve. The success of this line of valves in our } \\
\text { service created a demand by other industries. The current product line is } 1 " \text { thru } \\
4 \text { " with working pressures ranging from } 1000 \text { PSI through } 15,000 \text { PSI. }\end{array}$} \\
\hline \multicolumn{3}{|c|}{$\begin{array}{l}\text { BRIEF STATEMENT AS TO DEVELOPMENTAL AND TESTING CAPABILITIES } \\
\text { The Halliburton Services Research Development and Manufacturing Capabilities are } \\
\text { more than adequate to develop services or products related to 0il Well Servicing } \\
\text { and other areas of opportunity. }\end{array}$} \\
\hline \multicolumn{3}{|c|}{$\begin{array}{l}\text { REMARKS: COMMENTS OF FUTURE PRODUCT LINES THAT MAY BE AVAILABLE BY 1982?, BY } 1987 \text { ? } \\
\text { As noted, our current line of valves is not compatible with specifications of } \\
\text { this survey. Halliburton Services would review the findings of this survey with } \\
\text { interest to determine if the future demand would indicate a sufficient demand } \\
\text { for development of product. }\end{array}$} \\
\hline \multicolumn{3}{|c|}{$\begin{array}{l}\text { * LIST NAME AND ADDRESS AS YOU WOULD LIKE TO HAVE LISTED IN THE FINAL REPORT } \\
\text { Leonard Leon, Executive V.P., P. 0. Dr. 1431, Duncan, Oklahoma } 73533 \\
\text { Bob Diggs Brown, Vice President, P. 0. Drawer 1431, Duncan, Okiahoma } 73533\end{array}$} \\
\hline
\end{tabular}




\begin{tabular}{|c|c|c|}
\hline \multirow{2}{*}{$\begin{array}{l}\text { FIRM NAME/ADDRESS/PHONE } \\
\text { Henry Valve Co. } \\
3215 \text { North Avenue } \\
\text { Melrose Park, IL } 60160\end{array}$} & $\begin{array}{c}\text { YEAR PRESENT FIRM ESTABLISHED } \\
1914\end{array}$ & $\begin{array}{l}\text { SURVEY DATE } \\
6 / 17 / 77\end{array}$ \\
\hline & $\begin{array}{l}\text { CONTACTS: NAME/TITLE/PHONE } \\
\text { R. S. Dickert, Sales Manager } \\
\text { (312) 261-3668 }\end{array}$ & \\
\hline \multicolumn{3}{|c|}{$\begin{array}{l}\text { FORMER FIRM NAME, IF ANY, AND YEAR ESTABLISHED } \\
\text { NONE }\end{array}$} \\
\hline \multicolumn{3}{|c|}{$\begin{array}{l}\text { PARENT COMPANY } \\
\text { NONE }\end{array}$} \\
\hline $\begin{array}{l}\text { VALVE PLANT LOCATIONS } \\
\text { Melrose Park, IL }\end{array}$ & \begin{tabular}{l|l} 
BER OF EMPLOYEES & PLAI \\
$\operatorname{der} 300$ &
\end{tabular} & FLOOR SPACE \\
\hline \multicolumn{3}{|c|}{$\begin{array}{l}\text { BRIEF STATEMENT AS TO STANDARD VALVE PRODUCTS } \\
\text { We manufacture a complete line of shut-off valves for the Refrigeration } \\
\text { and Air Conditioning Industry. } \\
\text { We do, however, make special items for other industries } \\
\text { To the best of my knowledge, we are not supplying any items to the coal industry. }\end{array}$} \\
\hline \multicolumn{3}{|c|}{$\begin{array}{l}\text { BRIEF STATEMENT AS TO DEVELOPMENTAL AND TESTIIVG CAPABILITIES } \\
\text { REMARKS: COMMENTS OF FUTURE PRODUCT LINES THAT MAY BE AVAILABLE BY 1982?, BY } 1987 ?\end{array}$} \\
\hline REMARKS: COMMENTS OF FU & & $82 ?$, BY 1987? \\
\hline * IIST ITAME AND ADDREESS & LIKE TO HAVE LISTED IN THE FIM & REPORT \\
\hline
\end{tabular}




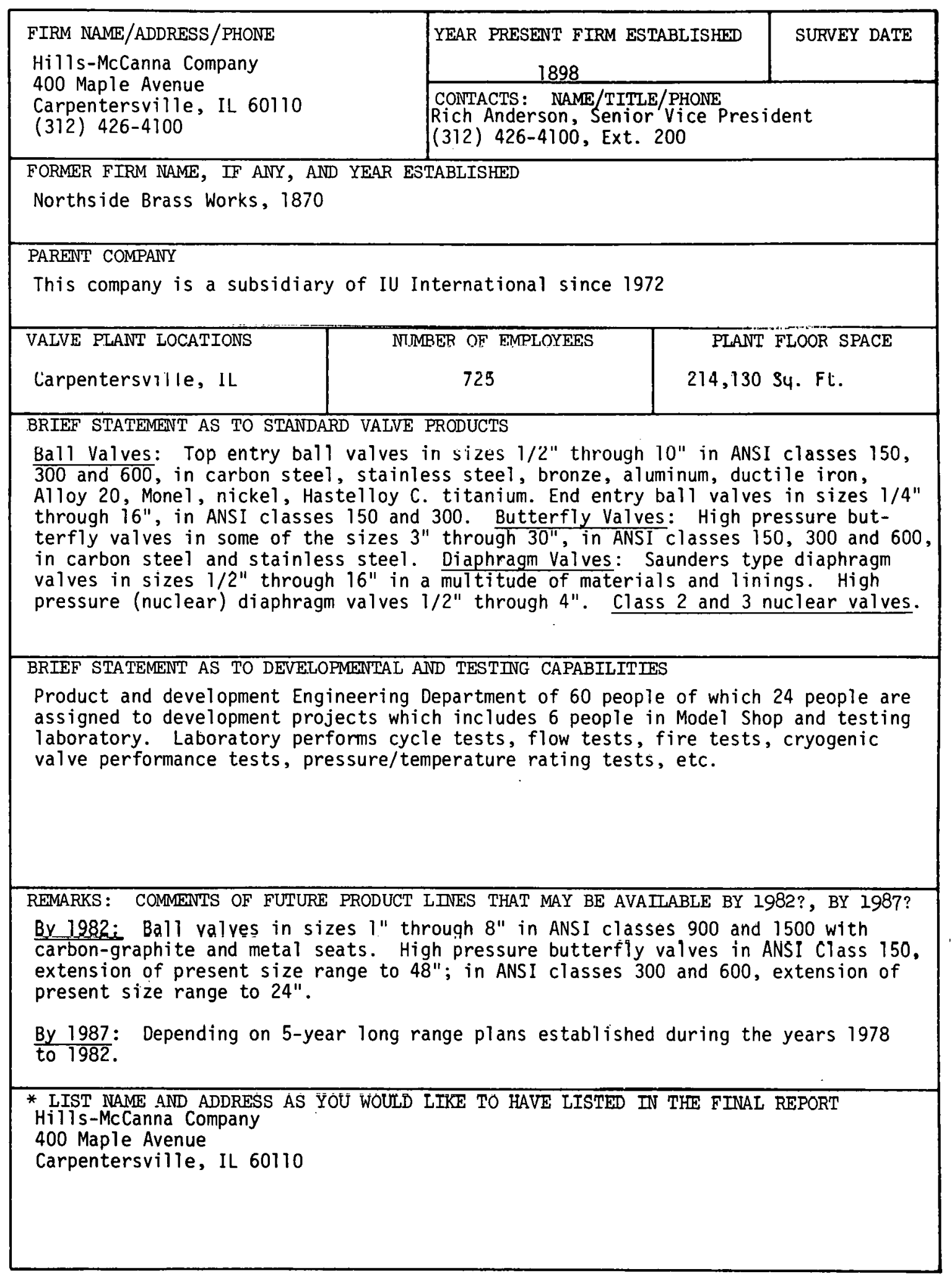




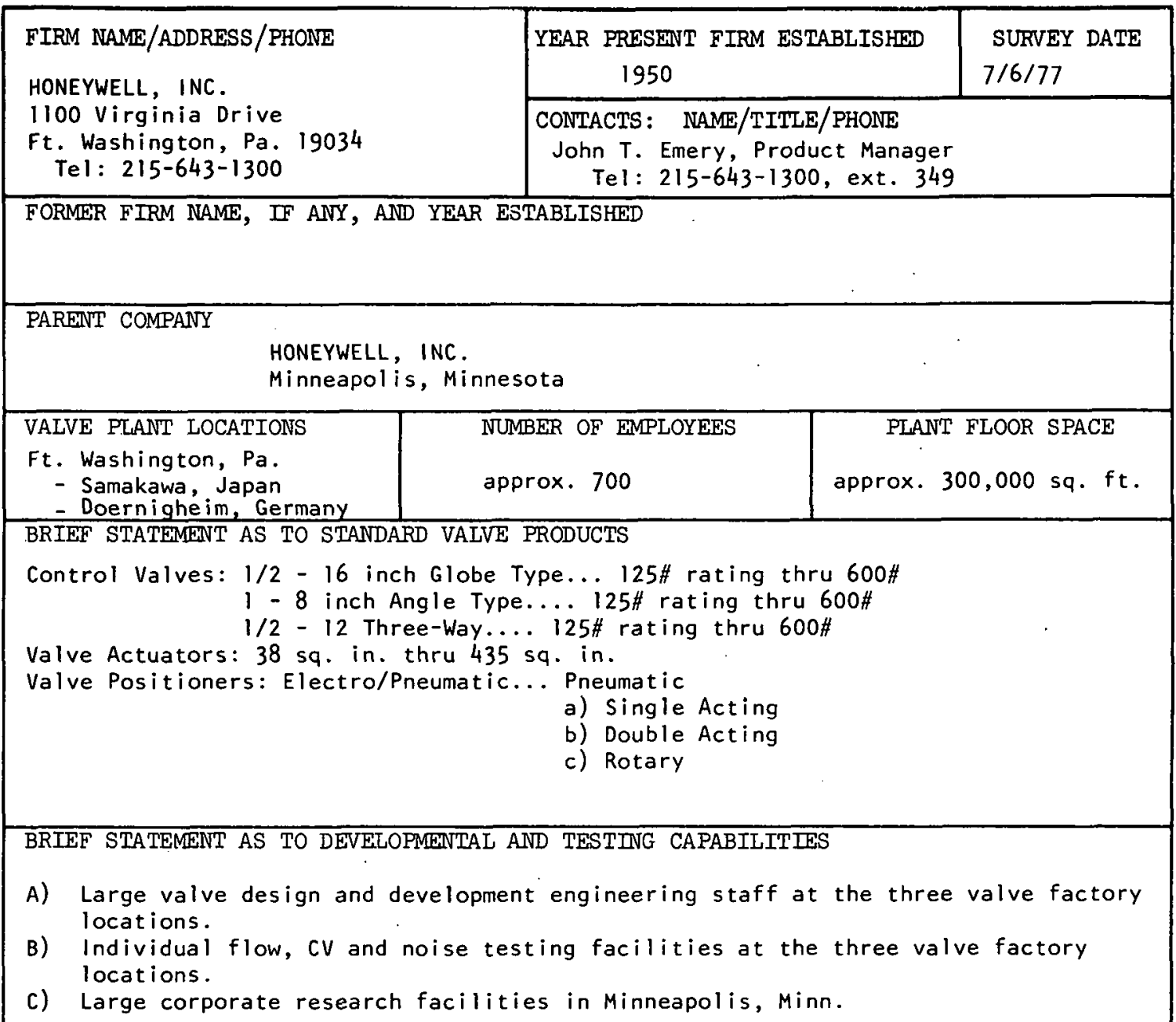

REMARKS: COMMENTS OF FUTURE PRODUCT LINES THAT MAY BE AVAIIABLE BY 1982?, BY 1987? More advanced globe valve designs, i.e., high pressure, noise.

* LIST NAIME AND ADDRESS AS YOU WOULD LIKE TO HAVE LISTED IN THE FINAL REPORT

John T. Emery, Product Manager, Valves

Honeywell, Inc.

1100 Virginia Drive

Ft. Washington, Pa. 19034 


\begin{tabular}{|c|c|c|}
\hline \multirow{2}{*}{$\begin{array}{l}\text { FIRM NAME/ADDRESS/PHONE } \\
\text { KAMYR VALVES, INC. } \\
\text { RIdge Center } \\
\text { Glens Falls, New York } 12801 \\
\text { (518) 793-5ill }\end{array}$} & $\begin{array}{l}\text { YEAR PRESENT FIRM ESTABLISHED } \\
\text { Jan. } 1,1976\end{array}$ & $\begin{array}{l}\text { SURVEY DATB } \\
\text { June } 1977\end{array}$ \\
\hline & \multicolumn{2}{|c|}{$\begin{array}{l}\text { CONTACTS: NAME/TITLE/PHONE } \\
\text { P. Kindersley, Exec.Vice Pres. (518) 793-5111 } \\
\text { W. Bowler, Sales Mgr. (518) 793-5111 } \\
\end{array}$} \\
\hline \multicolumn{3}{|c|}{$\begin{array}{l}\text { FORMER FIRM NAME, IF ANY, AND YEAR ESTABLISHED } \\
\text { Valve Division, Kamyr, Inc. } 1969\end{array}$} \\
\hline \multicolumn{3}{|l|}{$\begin{array}{l}\text { PARERT COMPANY } \\
\text { Kamyr, InC., Ri }\end{array}$} \\
\hline $\begin{array}{l}\text { VALVE PLANT LOCATIONS } \\
\text { Glens Falls, New York }\end{array}$ & \begin{tabular}{l|r} 
IBER OF EMPLOYEES & PLAI \\
41 & 10,000
\end{tabular} & $\begin{array}{l}\text { FLOOR SPACE } \\
\mathrm{ft} \text {. }\end{array}$ \\
\hline \multicolumn{3}{|c|}{$\begin{array}{l}\text { BRIGF STATEMIENT AS TO STANDARD VALVE PRODUCTS } \\
\text { Standard products are valves for severe services, involving abrasives, high } \\
\text { temperatures, high pressures, cavitation, impingement, fibers and solids, precip- } \\
\text { itates, polymers, ultra corrosive agents, high cycle rates. Kamyr valves have been } \\
\text { supplied to } 16 \text { coal conversion pilot and demonstration plants, mostly our standard } \\
\text { severe-service designs. }\end{array}$} \\
\hline \multirow{2}{*}{\multicolumn{3}{|c|}{$\begin{array}{l}\text { BRIEF STATEMENT AS TO DEVELOPMENTAL AND TESTTNG CAPABTLITIES } \\
\text { Unlimited as to development capabilities. } \\
\text { We are anxious to do development, and have been dcing so continuously since } 1972 \text {. } \\
\text { Testing services except dye penetrant are subcontracted, and therefore are unlimited } \\
\text { except by the extent to which they exist. Subcontracted services have included } \\
\text { seismic, tensile strength at } 2100^{\circ} \mathrm{F} \text {, creep at } 2100^{\circ} \mathrm{F} \text {, hardness, X-Ray, coefficient } \\
\text { of friction, corrosion resistance. and similar parameters required for design of } \\
\text { severe-service vdlves. } \\
\text { Certain special tests have been conducted by ourselves, including torsional strength } \\
\text { of ceramic rods at } 1600^{\circ} \mathrm{F} \text {, and leak test of valves while at } 1200^{\circ} \mathrm{F} \text {. An affiliated } \\
\text { company can do leak testing of } 120^{\prime \prime} \text { valves at up to } 2000^{\circ} \mathrm{F} \text { ambient temperature. }\end{array}$}} \\
\hline & & \\
\hline \multicolumn{3}{|c|}{ REMARKS: COMMENTS OF FUTURE PRODUCT LINES THAT MAY BE AVAIIABLLE BY 1982?, BY 1987? } \\
\hline \multicolumn{3}{|c|}{$\begin{array}{l}\text { We have sold all-metal values for } 2000^{\circ} \mathrm{F} \text {, and are designing for higher temperatures, } \\
\text { possibiy available by } 1980 \text {. } \\
\text { We are, and plan to continue to be in a position to supply valves for the coal con- } \\
\text { version processes, to exactly accomplish the valving functions required. We see a } \\
\text { need to provide valving solutions, not valves as a commodity. This is our goal. } \\
\text { The valves, therefore, have taken and will continue to take a wide variety of shapes } \\
\text { using some common basic technclogy. For clean, hot services, we will have catalog } \\
\text { valves up to } 30^{\prime \prime} \text { and up to } 1500^{\circ} \text { F, before } 1982^{2} \text {. }\end{array}$} \\
\hline \multicolumn{3}{|c|}{$\begin{array}{l}\text { * IIST NAMB AND ADDRESS AS YOU WOÜD LIKE TO HAVE LISTED IN THE F DNAL REPORT } \\
\text { Kamyr Valves, Inc. } \\
\text { Ridge Center } \\
\text { Glens Falls, New York } 12801\end{array}$} \\
\hline
\end{tabular}




\begin{tabular}{|c|c|c|}
\hline \multirow{2}{*}{$\begin{array}{l}\text { FIRM NAME/ADDRESS/PHONE } \\
\text { Kerotest Manufacturing Corp. } \\
2525 \text { Liberty Avenue } \\
\text { Pittsburgh, PA } 15222 \\
\text { (412) } 471-2584\end{array}$} & $\begin{array}{l}\text { YEAR PRESENT FIRM ESTABLISHED } \\
1909\end{array}$ & $\begin{array}{l}\text { SURVEY DATE } \\
7-8-77\end{array}$ \\
\hline & \multicolumn{2}{|l|}{$\begin{array}{l}\text { CONTACTS: NAME/TITLE/PHONE } \\
\text { Steven } j \text {. Caroleo } \\
\text { Vice President of Engineering }\end{array}$} \\
\hline \multicolumn{3}{|c|}{$\begin{array}{l}\text { FORMER FIRM NAME, IF ANY, AND YEAR ESTABLISHED } \\
\text { None }\end{array}$} \\
\hline \multicolumn{3}{|l|}{$\begin{array}{l}\text { PARENT COMPANY } \\
\text { Control Data Corporation }\end{array}$} \\
\hline $\begin{array}{l}\text { VALVE PLANT LOCATIONS } \\
\text { Same }\end{array}$ & \begin{tabular}{c|r} 
BER OF EMPLOYEES & PLAN \\
Shop \& Office & 70,000
\end{tabular} & $\begin{array}{l}\text { LOOR SPACE } \\
\text { Ft. }\end{array}$ \\
\hline \multicolumn{3}{|c|}{$\begin{array}{l}\text { BRIEF STATEMENT AS TO STANDARD VALVE PRODUCTS } \\
\text { Standard valve products serve two major market areas - power and industrial. Power } \\
\text { consists of } 1500 \text { and } 25001 \mathrm{~b} \text { rated valves } 4 " \text { and smaller for nuclear and fossil } \\
\text { fuel power plants. Industrial market includes Natural Gas Valve } 16 " \text { and smaller } \\
300 \# \text { rated for distribution and transmission lines. Also, included are several } \\
\text { small valves and fittings for commercial uses. }\end{array}$} \\
\hline \multicolumn{3}{|c|}{$\begin{array}{l}\text { BRIEF STATEMENT AS TO DEVETOPNENTAL AND TESTING CAPABILITIES } \\
\text { Kerotest has the capability of flow and operational testing valves } 4 " \text { and smaller } \\
\text { at temperatures up to } 650^{\circ} \mathrm{F} \text {. and pressures to } 2500 \text { psi. in a three station hot } \\
\text { test loop. We have also developed methods of static operational testing at high } \\
\text { and low temperatures. } \\
\text { This effort is backed by a group consisting of } 7 \text { Research and Development Engineers } \\
\text { and } 4 \text {. Laboratory Technicians. }\end{array}$} \\
\hline \multicolumn{3}{|c|}{$\begin{array}{l}\text { REMARKS: COMMENTS OF FUTURE PRODUCT LINES THAT MAY BE AVAIIABLE BY 1982?, BY } 1987 \text { ? } \\
\text { We have not finalized plans for development of future product lines. However, } \\
\text { we will have the necessary manpower, funds, etc. to investigate possible develop- } \\
\text { ment opportunities in the coal conversion process area. }\end{array}$} \\
\hline \multicolumn{3}{|c|}{$\begin{array}{l}\text { * LIST NAME AND ADDRESS AS YOU WOULD LIKE TO HAVE LISTED IN THE FINAL REPORT } \\
\text { As Above. }\end{array}$} \\
\hline
\end{tabular}




\begin{tabular}{|c|c|c|}
\hline $\begin{array}{l}\text { FIRM MAME/ } D D D R E S S / P H O N E \\
\text { Keystone Valve Division }\end{array}$ & YEAR PRESENT FIRM ESTABLISHED & $\begin{array}{l}\text { SIIRVEY RATE } \\
9-14-77\end{array}$ \\
\hline $\begin{array}{l}\text { Reystone International, Inc. } \\
9700 \text { W. Gulf Drive } \\
\text { Houston, TX } 77040\end{array}$ & $\begin{array}{l}\text { CONTACTS: NAME/TITLE/PHONE } \\
\text { Bert Klopfenstein } \\
\text { (713) } 466-1176\end{array}$ & \\
\hline
\end{tabular}

FORMER FIRM NAME, IF ANY, AND YEAR ESTABLISHED

PARENT COMPANY

\begin{tabular}{|l|l|l|}
\hline VALVE PLANT LOCATIONS & NUMBER OF EMPLOYEES & PLANT FLOOR SPACE \\
\hline
\end{tabular}

BRIEF STATEMENT $\Lambda S$ TO STANDARD VALVE PRODUCTS

NOTE:

Complete line of Butterfly valves having rosiliont seats

BRIEF STATEMENT AS TO DEVELOPMENTAL AND TESTING CAPABILITIES

REMARKS: COMMENTS OF FUTURE PRODUCT LINES THAT MAY BE AVAIILABLE BY 1982?, BY, 1987?

\section{NOTE:}

Keystone has a researeh and development program which could result in the development of valves which will have oapabilities both in temperature and material to handle some of the severe applications in the coal conversion industry.

* LIST INAME AND ADDRESS AS YOU WOULD LIKE TO HAVE LISTED IN THE FLNAL REPORT 


\begin{tabular}{|c|c|c|}
\hline \multirow{2}{*}{$\begin{array}{l}\text { FIRM NAME/ADDRESS/PHONE } \\
\text { Kieley and Mueller, Inc. } \\
64 \text { Genung Street } \\
\text { Middletown, NY } 10940 \\
\text { (914) } 343-0531\end{array}$} & $\begin{array}{l}\text { YEAR PRESEATT FIRM ESTABLISHED } \\
1879\end{array}$ & $\begin{array}{l}\text { SURVEY DATE } \\
8 / 5 / 77\end{array}$ \\
\hline & \multicolumn{2}{|c|}{$\begin{array}{l}\text { CONTACTS: NAME/TITLE/PHONE } \\
\text { John W. Post, Marketing Services Mgr. } \\
\text { Henry Illing, Research \& Development Mgr. }\end{array}$} \\
\hline \multicolumn{3}{|c|}{$\begin{array}{l}\text { FORMER FIRM NAME, IF ANY, AND YEAR ESTABLISHED } \\
\text { None }\end{array}$} \\
\hline \multicolumn{3}{|l|}{$\begin{array}{l}\text { PARENT COMPANY } \\
\text { Johnson Controls, Inc. }\end{array}$} \\
\hline $\begin{array}{l}\text { VALVE PLANT' LOCATIONS } \\
\text { Middletown, NY } \\
\text { Hous ton, TX. }\end{array}$ & \begin{tabular}{l|r} 
BER OF EMPLOYEES & PLAN \\
200 & 50,000
\end{tabular} & $\begin{array}{l}\text { LOOR SPACE } \\
\text { Ft. }\end{array}$ \\
\hline \multicolumn{3}{|c|}{$\begin{array}{l}\text { BRIEF STATEMENT AS TO STANDARD VALVE PRODUCTS } \\
\text { We now manufacture automatic control valves and level controllers. Automatic } \\
\text { control valves consist of globe, angle, cage, 3-way, butterfly vaives. Sizes on } \\
\text { globe style, } 1 / 2^{\prime \prime} \text { through } 20^{\prime \prime} \text {, Butterfly, } 2^{\prime \prime} \text { through } 24^{\prime \prime}\end{array}$} \\
\hline \multicolumn{3}{|c|}{$\begin{array}{l}\text { BRIEF STATEMENT AS TO DEVELOPMENTAL AND TESTING CAPABILITIES } \\
\text { Three to six people. Water test loop } 1200 \mathrm{psi}, 800 \mathrm{GPM} \text { with temperature control } \\
\text { from } 70^{\circ} \mathrm{F} \text { to } 150^{\circ} \mathrm{F} \text {. } \\
\text { Gas fire temperature test chamber to } 2000^{\circ} \mathrm{F} \text {. } \\
\text { Helium Leak test equipment to } 10-8 .\end{array}$} \\
\hline \multicolumn{3}{|c|}{$\begin{array}{l}\text { REMARKS: COMMENTS OF FUTURE PRODUCT LINES THAT MAY BE AVAILABLE BY 1982?, BY } 1987 ? \\
\text { A } 2000 \text { cubic foot blowdown type air test facility. } \\
\text { Additional noise abatement valves and trim styles by } 1982 \text {. New Actuator types; } \\
\text { Type } 1982 \text {. }\end{array}$} \\
\hline $\begin{array}{l}\text { * LIST NAME AND ADDRESS AS } \\
\text { Kieley and Mueller, Inc. } \\
64 \text { Genung Street } \\
\text { Middletown, NY } 10940\end{array}$ & LIKE TO HAVE LISTED IN THE FINA & $\overline{P O R T}$ \\
\hline
\end{tabular}




\begin{tabular}{|c|c|c|}
\hline \multirow{2}{*}{$\begin{array}{l}\text { FIRM NAME/ADDRESS/PHONE } \\
\text { LADISH CO. } \\
5481 \text { South Packard Avenue } \\
\text { Cudahy, WI } 53110 \\
(414747-2611\end{array}$} & $\begin{array}{l}\text { YEAR PRESENT FIRM ESTABLISHED } \\
1905\end{array}$ & $\begin{array}{l}\text { SURVEY DATE } \\
7 / 8 / 77\end{array}$ \\
\hline & \multicolumn{2}{|l|}{$\begin{array}{l}\text { CONTACTS: NAME/TITLE/PHONE } \\
\text { F. K. Krel1, Vice President } \\
(414747-2800\end{array}$} \\
\hline \multicolumn{3}{|c|}{$\begin{array}{l}\text { FORMER FIRM NAME, IF ANY, AND YEAR ESTABLISHED } \\
\text { Ladish Drop Forge Co. (Change in name on } 1 y \text { ) }\end{array}$} \\
\hline \multicolumn{3}{|l|}{$\begin{array}{l}\text { PAREINT COMPANY } \\
\text { As Above }\end{array}$} \\
\hline $\begin{array}{l}\text { VALVE PLANT LOCATIONS } \\
\text { Cynthiana, KY }\end{array}$ & \begin{tabular}{l|r} 
BER OF EMPLOYEES & PLAN \\
200,000
\end{tabular} & $\begin{array}{l}\text { LOOR SPACE } \\
\text { Ft } \cdots\end{array}$ \\
\hline \multicolumn{3}{|c|}{$\begin{array}{l}\text { BRIEF STATEMENT AS TO STANDARD VALVE PRODUCTS } \\
\text { Corrosion resistant cast steel valves - } 18^{\prime \prime} \text { and smaller - } 150 \#-300 \# \text { and } 600 \# \\
\text { Cast stainless steel, Monel, Hastelloy, nickel, tantalum, titanium, and other } \\
\text { castable alloys. }\end{array}$} \\
\hline \multicolumn{3}{|c|}{$\begin{array}{l}\text { BRIEF STATEMENT AS TO DEVELOPMENTAL AND TESTING CAPABILITIES } \\
\text { Fully equipped lab and testing capacity required for our regular valve production. }\end{array}$} \\
\hline \multicolumn{3}{|c|}{$\begin{array}{l}\text { REMARKS: COMMENTS OF FUTURE PRODUCT LINES THAT MAY BE AVAILABLE BY 1982?, BY 1987? } \\
\text { Forged steel valves in complete range of pressure ratings. }\end{array}$} \\
\hline \multicolumn{3}{|c|}{$\begin{array}{l}\text { * LIST NAME AND ADDRESS AS YOU WOILD LIKE TO HAVE LISTED IN THE FINAL REPORT } \\
\text { Ladish Company, } \\
\text { Fittings Division and Valve Division, } \\
\text { Cudahy, WI } 53110\end{array}$} \\
\hline
\end{tabular}




\begin{tabular}{|c|c|c|}
\hline \multirow{2}{*}{$\begin{array}{l}\text { FIRM NAME/ADDRESS/PHONE } \\
\text { Lockheed Missiles \& Space Co, Inc. } \\
\text { Palo Alto Research Laboratory } \\
3251 \text { Hanover Street } \\
\text { Palo Alto, CA } 94304\end{array}$} & $\begin{array}{c}\text { YEAR PRESENT FIRM ESTABLISHED } \\
1954\end{array}$ & $\begin{array}{l}\text { SURVEY DATE } \\
7 / 19 / 77\end{array}$ \\
\hline & \multicolumn{2}{|l|}{ CONTACTS: NAME/TITLE/PHONE } \\
\hline \multicolumn{3}{|c|}{ FORMER FIRM NAME, IF ANY, AND YEAR ESTABLISHED } \\
\hline \multicolumn{3}{|l|}{$\begin{array}{l}\text { PARENT COMPANY } \\
\text { Lockheed Aircraft Corporation } \\
\text { Box 551, Burbank, CA } 91520\end{array}$} \\
\hline \begin{tabular}{l|l} 
VALVE PLANT LOCATIONS & NUI \\
Murdock Machine \& Eng. Co. & \\
of Texas & \\
Irving. Texas & \\
\end{tabular} & IBER OF EMPLOYEES & \\
\hline \multicolumn{3}{|c|}{$\begin{array}{l}\text { BRIEF STATEMENT AS TO STANDARD VALVE PRODUCTS } \\
\text { 1. Hot gas valves and integrated control system for Trident } \\
\text { 2. Rotary sleeve valve ( } 700 \text { psi, } 6000^{\circ} \mathrm{F}, \mathrm{A}_{2} \mathrm{O}_{3} \text { particulate flow) } \\
\text { 3. Vortex valves (fluid flow control, hot corrosive, erosive flow) } \\
\text { 4. } 2.5 \text { inch ball valve ( } 4200 \text { psi, "Lockseal" shear mount) } \\
\text { 5. Tunnel and pipe seal containment closure (rapid closure, large size, } 100 \text { psi, } \\
\text { 6. Articulating rocket support (gas tight, high temperature gimbaling seal) } \\
\text { 7. Hot gas generator seals (all metal, } 2000^{\circ} \text { psi, } 2300^{\circ} \mathrm{F} \text {, reactive flows) } \\
\text { Development would be required to convert these valves to coal utilization. }\end{array}$} \\
\hline \multicolumn{3}{|c|}{$\begin{array}{l}\text { BRIEF STATEMENT AS TO DEVELOPMENTAL AND TESTING CAPABILITIES } \\
\text { Hydrostatic and actuator test facilities exist at Murdock with capabilities to } \\
\text { thousands of psi. Laboratory support exists at the Lockheed Palo Alto Research } \\
\text { Laboratory in the areas of materials science, structures analysis, and heat transfer } \\
\text { Materials analyses equipment includes metallography, x-ray, electron beam analyzer, } \\
\text { electron microscope, and hardness testing. other facilities include a coating } \\
\text { laboratory, metal working and heat treatment, mechanical testing, and a fracture } \\
\text { and fatigue laboratory. } \\
\text { In addition, the Lockheed coal Feeder Test Facilities includes a high pressure sys- } \\
\text { tem of storage tanks and solids and pneumatic transport plumbing. This facility } \\
\text { can be used in a valve development program for coal utilization applications. } \\
\text { The facility can be remotely controlled and is supported by a wide array of } \\
\text { automatic instrumentation and recording equipment. The test area has been safety } \\
\text { inspected and strict safety procedures are adhered to at all times. Supporting } \\
\text { gas supplies and compressors are available. }\end{array}$} \\
\hline
\end{tabular}

REMARKS: COMMENTS OF FUTURE PRODUCT LINES THAT MAY BE AVAILABLE BY 1982? BY 1987?

* T.TST NAME AND ADDRESS AS YOU WOULD LIKE TO HAVE LISTED IN THE INLNAL REFORT

R. A. Kuiper

0/52-13, Bldq. 201, Plant 2

Lockheed Palo Al to Research Laboratory

3251 Hanover Street

Palo Alto, CA 94304 


\begin{tabular}{|c|c|}
\hline \multirow{2}{*}{$\begin{array}{l}\text { FIRM NAME/ADDRESS/PHONE } \\
\text { J. E. Lonergan Company } \\
\text { P. O. Box } 6167 \\
\text { Philadelphia, PA } 19115\end{array}$} & $\begin{array}{c}\text { YEAR PRESENT FIRM ESTABLISHED } \\
1872\end{array}$ \\
\hline & $\begin{array}{l}\text { CONTACTS: NAME/TITLE/PHONE } \\
\text { Joseph Zuraski, Quality Assurance Manager } \\
(215) 677-1710\end{array}$ \\
\hline \multicolumn{2}{|c|}{$\begin{array}{l}\text { FORMER FIRM NAME, IF ANY, AND YEAR ESTABLISHED } \\
\text { None }\end{array}$} \\
\hline \multicolumn{2}{|l|}{$\begin{array}{l}\text { PAREIVT COMPANY } \\
\text { None }\end{array}$} \\
\hline $\begin{array}{l}\text { VALVE PLANT LOCATIONS } \\
10050 \text { Sandmeyer Lane } \\
\text { Philadelphia, PA }\end{array}$ & \begin{tabular}{l|l} 
BER OF EMPLOYEES & PLANT FLOOR SPACE \\
& $39,000 \mathrm{Sq} . \mathrm{Ft}$.
\end{tabular} \\
\hline \multicolumn{2}{|c|}{$\begin{array}{ll}\text { Safety Valves } & \text { Valves available for steam, air, gas, } \\
\text { Safety Relief Valves } & \text { and liquid services } \\
\text { Relief Valves } & \text { Sizes } 1 / 2^{\prime \prime} \text { thru } 16^{\prime \prime} \text { Steam Service } \\
& \text { Sizes } 1 / 2^{\prime \prime} \text { thru } 8 " \text { Air and Gas Service } \\
& \text { Sizes } 1 / 2^{\prime \prime} \text { thru } 8 " \text { Liquid Service }\end{array}$} \\
\hline \multicolumn{2}{|c|}{$\begin{array}{l}\text { BRIEF STATEMENT AS TO DEVELOPMENTAL AND TESTING CAPABILITIES } \\
\text { Steam Boilers for steam testing } \\
\text { Air compressors for air testing } \\
\text { Liquid pumps for liquid testing }\end{array}$} \\
\hline \multicolumn{2}{|c|}{$\begin{array}{l}\text { REMARKS: COMMENTS OF FUTURE PRODUCT LINES THAT MAY BE AVAILABLE BY 1982?, BY 1987? } \\
\text { Research and development is a constant factor that determines future product } \\
\text { lines in order to meet the marketing demands. }\end{array}$} \\
\hline \multicolumn{2}{|c|}{$\begin{array}{l}\text { * LIST NAME AND ADDRESS AS YOU WOULD LIKE TO HAVE LISTED IN THE FINAL REFORT } \\
\text { J. E. Lonergan Company } \\
\text { P. 0. Box } 6167 \\
\text { 10050 Sandmeyer Lane } \\
\text { Philadelphia. PA } 19115\end{array}$} \\
\hline
\end{tabular}




\begin{tabular}{|c|c|c|}
\hline \multirow{2}{*}{$\begin{array}{l}\text { FIRM NAME/ADDRESS/PHONE. } \\
\text { The Lunkenheimer Company } \\
\text { Div. of Conval Corp. } \\
\text { P. 0. Box } 14360 \\
\text { Cincinnati, 0hio } 45214 \\
\text { (512) } 921-3400\end{array}$} & $\begin{array}{l}\text { YEAR PRESENT FIRM ESTABLISHED } \\
1968\end{array}$ & $\begin{array}{l}\text { SURVEY DATE } \\
6-24-77\end{array}$ \\
\hline & \multicolumn{2}{|c|}{$\begin{array}{l}\text { CONTACTS: NAME/TITLE/PHONE } \\
\begin{array}{ll}\text { H. Ewell Rains } & (513) 921-3400 \\
\text { Mgr. Sales Services - Energy Div. }\end{array}\end{array}$} \\
\hline \multicolumn{3}{|c|}{ FORMER FIRM NAME, IF ANY, AND YEAR ESTABLISHED } \\
\hline \multicolumn{3}{|c|}{ The Lunkenheimer Company - 1862} \\
\hline \multicolumn{3}{|c|}{$\begin{array}{l}\text { PARENT COMPANY } \\
\text { Condec Corporation, old Greenwich, CT }\end{array}$} \\
\hline $\begin{array}{l}\text { VALVE PLANT LOCATIONS } \\
\text { Cincinnati, OH } \\
\text { Wadsworth, } \mathrm{OH}\end{array}$ & $\begin{array}{l}\text { BER OF EMPLOYEES } \\
600\end{array}$ & $\begin{array}{l}\text { LOOR SPACE } \\
\text { SQ. Ft. }\end{array}$ \\
\hline \multicolumn{3}{|c|}{$\begin{array}{l}\text { BRIEF STATEMENT AS TO STANDARD VALVE PRODUCTS } \\
\text { Bronze; Iron, Steel Gate, Globe \& Check Valves } 1 / 8 "-30 ", 125 \#-4500 \# \text { pressure } \\
\text { classes. Air devices, Cocks, Lubricators, Boiler Mountings, Butterfly Valves, } \\
\text { Ball Vaives, Electric and Pneumatic Actuators. }\end{array}$} \\
\hline \multicolumn{3}{|c|}{$\begin{array}{l}\text { BRIEF STATEMENT AS TO DEVELOPMENTAL AND TESTING CAPABILITIES } \\
\text { Engineering and design done in-house. Experimental Engineering Lab, Metallurgical, } \\
\text { NDE, Foundry Control. Production Department and Testing. Co-operate with R\&D } \\
\text { oriented sister company, Consolidated Controls Corp., El Segundo, California. }\end{array}$} \\
\hline \multicolumn{3}{|c|}{$\begin{array}{l}\text { REMARKS: COMMENTS OF FUTURE PRODUCT LINES THAT MAY BE AVAILABLE BY 1982?, BY 1987? } \\
\text { No Comment }\end{array}$} \\
\hline \multicolumn{3}{|c|}{$\begin{array}{l}\text { * LIST NAME AND ADDRESS AS YOU WOULD LIKE TO HAVE LISTED IN THE FINAL REPORT } \\
\text { Same as Above, Top Left Block }\end{array}$} \\
\hline
\end{tabular}




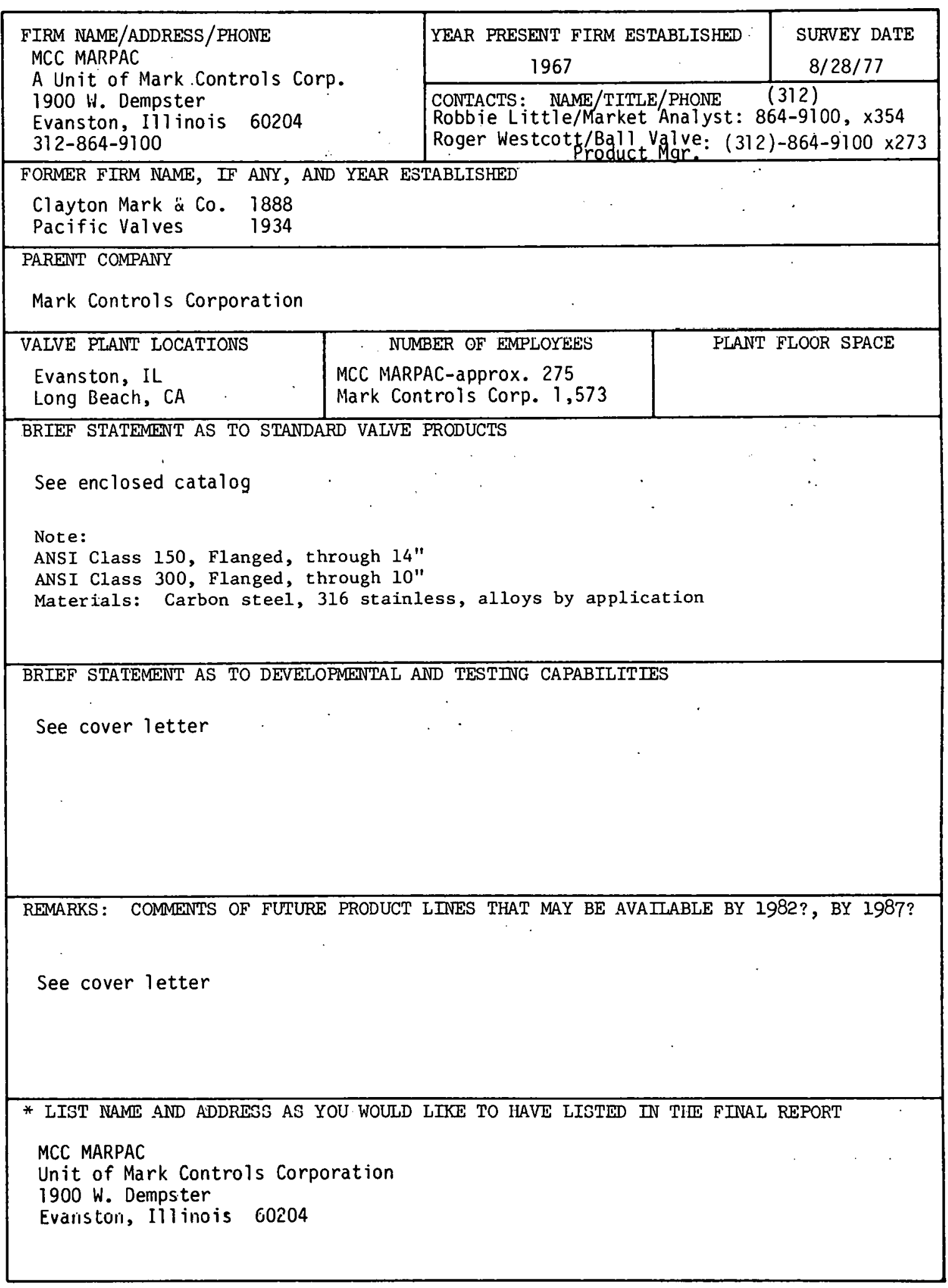




\begin{tabular}{|c|c|c|}
\hline \multirow{2}{*}{$\begin{array}{l}\text { FIRM NAME/ADDRESS/PHONE } \\
\text { PEABODY DORE' CORPORATION } \\
\text { P. O. BOX } 42081 \\
\text { Houston, TX } 77042 \\
\text { (713) } 498-6380\end{array}$} & $\begin{array}{c}\text { YEAR PRESENT FIRM ESTABLISHED } \\
1972\end{array}$ & $\begin{array}{l}\text { SURVEY DATE } \\
7-22-77\end{array}$ \\
\hline & \multicolumn{2}{|c|}{$\begin{array}{l}\text { CONTACTS: NAME/TITLE/PHONE } \\
\text { B. R. Murphree, Dir. Engr. \& Res. } \\
(713) 498-6380\end{array}$} \\
\hline \multicolumn{3}{|c|}{$\begin{array}{l}\text { FORMER FIRM NAME, IF ANY, AND YEAR ESTABLISHED } \\
\text { John L. Dore' Co. } \quad 1952\end{array}$} \\
\hline \multicolumn{3}{|c|}{$\begin{array}{l}\text { PARENT COMPANY } \\
\text { Peabody International Corporation }\end{array}$} \\
\hline $\begin{array}{l}\text { VALVE PLANT LOCATIONS } \\
\text { Houston, Texas }\end{array}$ & \begin{tabular}{l|r} 
BER OF EMPLOYEES & PLAI \\
325 & 120,0 \\
& 70,000 \\
\end{tabular} & $\begin{array}{l}\text { LOOR SPACE } \\
\text { Sq. Ft. Exist. } \\
\text {. under Const. }\end{array}$ \\
\hline \multicolumn{3}{|c|}{$\begin{array}{l}\text { BRIEF STATEMENT AS TO STANDARD VALVE PRODUCTS } \\
\text { Standard valve products at this time consist primarily of Teflon, Polypropylene, } \\
\text { and Kynar lined ductile iron plug valves, ball check valves, etc. The temperature } \\
\text { upper limit of the valve is determined by the type plastic liner that the valve is } \\
\text { lined with. In the case of Teflon, temperatures up to and including } 450^{\circ} \mathrm{F} \text { can be } \\
\text { reached. The standard valves, as now designed, are I50\# ASA ratings. }\end{array}$} \\
\hline \multicolumn{3}{|c|}{$\begin{array}{l}\text { BRIEF STA TEMENT AS TO DEVELOPMENTAL AND TESTING CAPABILITIES } \\
\text { We have complete engineering, manufacturing, and testing facilities to design, } \\
\text { manufacture and totally test new valve concepts, designs, etc. The testing would } \\
\text { include cycle life, temperature cycling, pressure cycling and shock tests. }\end{array}$} \\
\hline \multicolumn{3}{|c|}{$\begin{array}{l}\text { REMARKS: COMMENTS OF FUTURE PRODUCT LINES THAT MAY BE AVAIIABLE BY } 1982 \text { ?, BY } 1987 \text { ? } \\
\text { By 1982, we could have a completed lined valve with a product such as Kynar, Teflon, } \\
\text { Polypropylene, etc. with a } 300 \# \text { rating up through } 12 " \text { size. This would be a full } \\
\text { bore type valve. It could be ball or plug valve. Again, temperature limitations } \\
\text { would be based on the type of liner used to protect the internal parts of the valve } \\
\text { from the commodity. } \\
\text { By } 1987 \text { valves could be in the } 24 " \text { range and temperature limitations would be based } \\
\text { on availability of new higher temperature, higher pressure lining materials at that } \\
\text { time. }\end{array}$} \\
\hline \multicolumn{3}{|c|}{$\begin{array}{l}\text { * LIST NAME AND ADDRESS AS YOU WOULD LIKE TO HAVE LISTED IN THE FINAL REPORT } \\
\text { B. R. Murphree, Director } \\
\text { Engineering \& Research } \\
\text { PEABODY DORE' CORPORATION }\end{array}$} \\
\hline
\end{tabular}




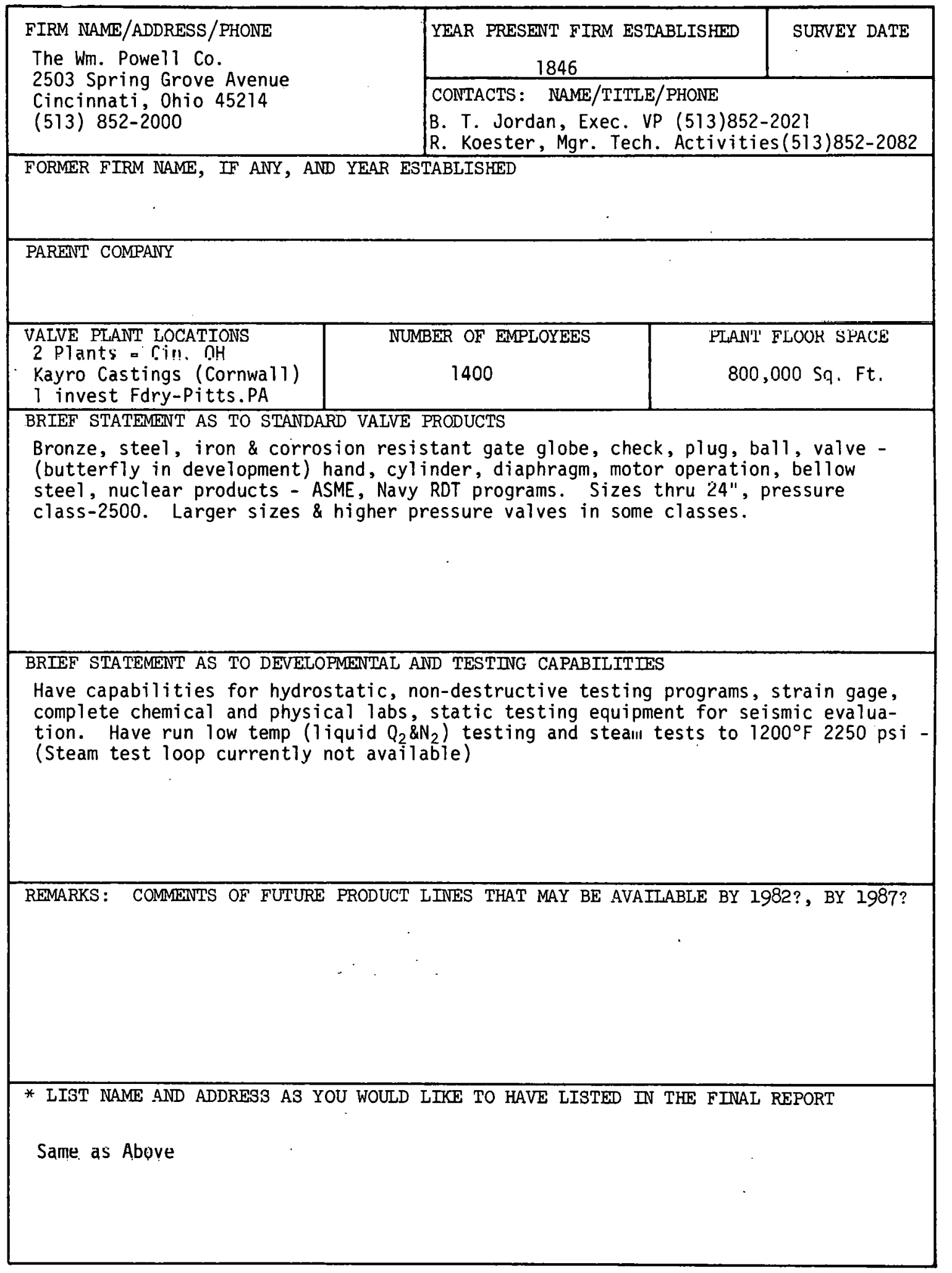




\begin{tabular}{|c|c|c|}
\hline \multirow{2}{*}{$\begin{array}{l}\text { FIRM NAME/ADDRESS/PHONE } \\
\text { RKL Controls, Inc. } \\
\text { Hainesport Ind. Park } \\
\text { Hainesport, NJ } 08036 \\
\text { (609) } 267-2800\end{array}$} & $\begin{array}{c}\text { YEAR PRESENT FIRM ESTABLISHFD } \\
1959\end{array}$ & $\begin{array}{c}\text { SURVEY DATE } \\
6-21-77\end{array}$ \\
\hline & \multicolumn{2}{|l|}{$\begin{array}{l}\text { CONTACTS: NAME/TITLE/PHONE } \\
\text { Robert K. Little, President } \\
(609) 267-2800\end{array}$} \\
\hline \multicolumn{3}{|c|}{$\begin{array}{l}\text { FORMER FIRM NAME, IF ANY, AND YEAR ESTABLISHED } \\
\text { RKL Valve \& Mfg. Co. } 1955\end{array}$} \\
\hline \multicolumn{3}{|l|}{$\begin{array}{l}\text { PAREINT COMPANY } \\
\text { None }\end{array}$} \\
\hline $\begin{array}{l}\text { VALVE PLAINT LOCATIONS } \\
\text { Lumberton, } \mathrm{NJ} \& \\
\text { Hainesport, } \mathrm{NJ}\end{array}$ & \begin{tabular}{l|r} 
BER OF EMPLOYEES & PLAI \\
60 & 40,00 \\
& 12,00 \\
\end{tabular} & $\begin{array}{l}\text { LOOR SPACE } \\
\text { q. Ft. } \\
\text { q. Ft. }\end{array}$ \\
\hline \multicolumn{3}{|c|}{$\begin{array}{l}\text { BRIEF STATEMENT AS TO STANDARD VALVE PRODUCTS } \\
\text { Largest line of Pinch Type control valves available in the world, many produced } \\
\text { under RKL patents. Also produce pneumatic actuators, process flow vibration joints } \\
\text { and expansion joints. }\end{array}$} \\
\hline \multicolumn{3}{|c|}{$\begin{array}{l}\text { BRIEF STATEMENT AS TO DEVELOPMENTAL AND TESTING CAPABILITIES } \\
\text { RKL has been the leader in developing new types of pinch valves for high and low } \\
\text { pressure (negative). First with pre-pinch for flow control. First and only 3-way } \\
\text { pinch type valve. First and only full line of molded elastomeric pinch valve bodies } \\
\text { First and only hand lever operated pinch valve. All necessary R\&D capability for } \\
\text { development and testing valves to } 5,000 \text { psig line pressure. }\end{array}$} \\
\hline \multicolumn{3}{|c|}{$\begin{array}{l}\text { REMARKS: COMMENTS OF FUTURE PRODUCT LINES THAT MAY BE AVAIIABLE BY 1982?, BY } 1987 ? \\
\text { Expect to have a } 4,000 \text { psig series on the market by I980 using new technique for } \\
\text { flow control with electronic positioning. Expect to have V.H.T., very high } \\
\text { temp., valve available by } 1982 \text { in sizes to } 36^{\prime \prime} \text {. }\end{array}$} \\
\hline $\begin{array}{l}\text { * LIST NAINE AND ADDRESS } \\
\text { RKL Controls, Inc. } \\
\text { Ark \& Eayerstown Rd. } \\
\text { Lumberton, NJ } 08048\end{array}$ & IKE TO HAVE LISTED IN THE FINA & EPORT \\
\hline
\end{tabular}




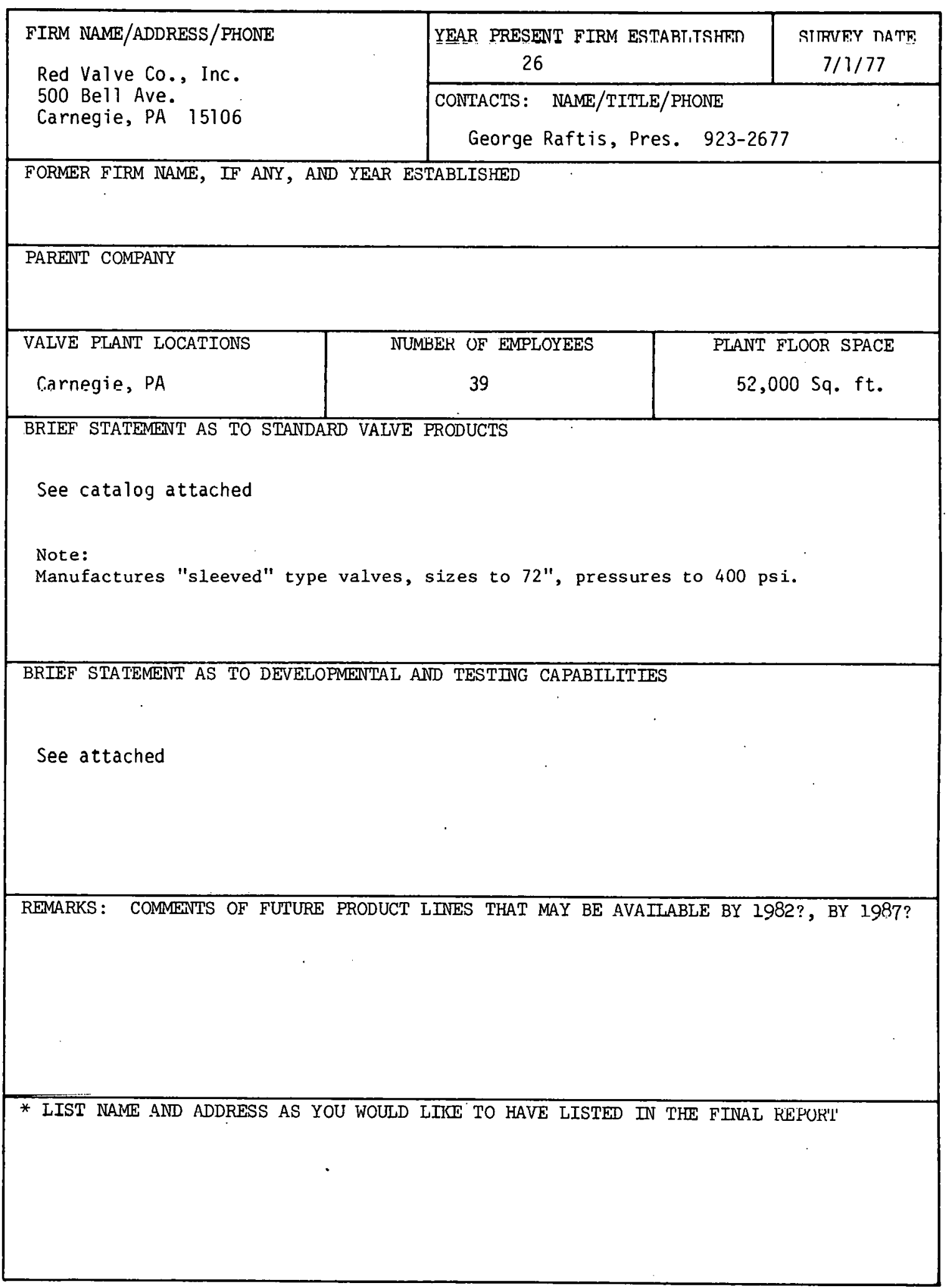




\begin{tabular}{|c|c|c|}
\hline \multirow{2}{*}{$\begin{array}{l}\text { FIRM NAME/ADDRESS/PHONE } \\
\text { Rockwell International Corporation } \\
\text { Flow Control Division } \\
400 \text { N. Lexington Avenue } \\
\text { Pittsburgh, PA } 15208\end{array}$} & $\begin{array}{l}\text { YEAR PRESENT FIRM ESTABLISHED } \\
\text { Februạry, } 1973\end{array}$ & $\begin{array}{l}\text { SURVEY DATE } \\
7-15-77\end{array}$ \\
\hline & \multicolumn{2}{|c|}{ 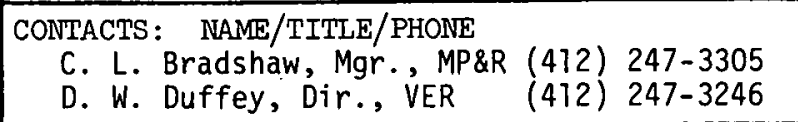 } \\
\hline \multicolumn{3}{|c|}{$\begin{array}{l}\text { FORMER FIRM NAME, IF ANY, AND YEAR ESTABLISHED } \\
\text { Rockwell Manufacturing Company, } 1925\end{array}$} \\
\hline \multicolumn{3}{|l|}{$\begin{array}{l}\text { PARENT COMPANY } \\
\text { Rockwe11 International Corporation }\end{array}$} \\
\hline \begin{tabular}{l|r} 
VALVE PLANT LOCATIONS & NU \\
See (2) below & apl
\end{tabular} & $\begin{array}{l}\text { BER OF EMPLOYEES } \\
\text { roximately } 2,000\end{array}$ & $\begin{array}{l}\text { LOOR SPACE } \\
\text { ely } 1,100,000\end{array}$ \\
\hline \multicolumn{3}{|c|}{$\begin{array}{l}\text { BRIEF STATEMENT AS TO STANDARD VALVE PRODUCTS } \\
\text { (1) The Flow Control Division manufactures: lubricated and non-lubricated plug } \\
\text { valves; valve sealants and applicators; iron castings; plastic gas distribution } \\
\text { valves; forged globe valves; cast steel globe and gate valves; and trunnion } \\
\text { mounted pipel ine ball valves. } \\
\text { (2) U.S. Valve Plants Located in: Barberton, Ohio; Kearney, Nebraska; Pittsburgh, } \\
\text { Pentrisylvania; Raleigh, North Carolina; Sulphur Springs, Texas. }\end{array}$} \\
\hline \multicolumn{3}{|c|}{$\begin{array}{l}\text { BRIEF STATEMENT AS TO DEVELOPNENTAL AND TESTING CAPABILITIES } \\
\text { The Division's product engineering and research organization totals approximately } \\
170 \text { persons at headquarters and five manufacturing plants. } \\
\text { Central to this organization is the Valve Engineering and Research (VER) group. } \\
\text { The group includes a score of Materials Engineering experts (organized in two } \\
\text { sections: Chemical and Metallurgical Engineering), a weld lab, a model shop, } \\
\text { and two flow test labs. }\end{array}$} \\
\hline \multicolumn{3}{|c|}{$\begin{array}{l}\text { REMARKS: COMMENTS OF FUTURE PRODUCT LINES THAT MAY BE AVAILABLE BY 1982?, BY 1987? } \\
\text { Proprletary information: } \\
\text { The Division, however, continually conducts R\&D work regarding potential new } \\
\text { valve designs which will meet the future requirements of the energy markets it } \\
\text { serves. }\end{array}$} \\
\hline $\begin{array}{l}\text { * LIST NAME AND ADDRESS AS YOU WOULD } \\
\text { Rockwell International Corporation } \\
\text { Flow Control Division } \\
\text { 40U N. Lexington Avenue } \\
\text { Pittsburgh, PA } 15208\end{array}$ & 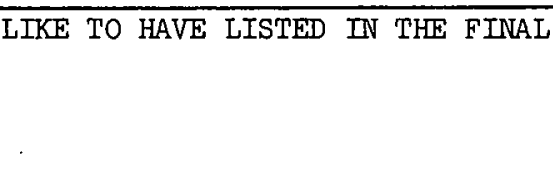 & 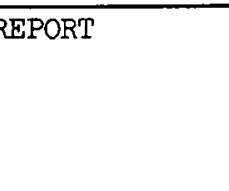 \\
\hline
\end{tabular}




\begin{tabular}{|c|c|}
\hline \multirow{2}{*}{$\begin{array}{l}\text { FIRM NAME/ADDRESS/PHONE } \\
\text { Rockwood Systems Corporation } \\
80 \text { Second Street } \\
\text { So. Portland, ME } 04106\end{array}$} & $\begin{array}{l}\text { YEAR PRESENT FIRM ESTABLISHED } \\
1973\end{array}$ \\
\hline & $\begin{array}{l}\text { CONTACTS: NAME/TITLE/PHONE } \\
\text { A. Latham, Sales Manager } \\
\text { C.L. Reed, Sales Manager, Ball Valves } 799-3341 \\
\end{array}$ \\
\hline \multicolumn{2}{|c|}{$\begin{array}{l}\text { FORMER FIRM NAME, IF ANY, AND YEAR ESTABLISHED } \\
\text { N/A }\end{array}$} \\
\hline \multicolumn{2}{|l|}{$\begin{array}{l}\text { PARENT COMPANY } \\
\text { Arkbridge Corporation }\end{array}$} \\
\hline \begin{tabular}{l|} 
VALVE PLANT LOCATIONS \\
South Portiand, Maine
\end{tabular} & \begin{tabular}{l|c} 
BER OF EMPLOYEES & PLANT FLOOR 3PACE \\
IUS & $150,000 \mathrm{su} \cdot \mathrm{ft}$.
\end{tabular} \\
\hline \multicolumn{2}{|c|}{$\begin{array}{l}\text { BRIEF STATEMENT AS TO STANDARD VALVE PRODUCTS } \\
\text { Brass, carbon steel, stainless steel ball vaives, } 1 / 4^{\prime \prime}-8 " \text { size and pneumatic } \\
\text { and eler.tric actuators for these valves. Pressures to } 800 \text { psi and temperature } \\
\text { to } 400^{\circ} \mathrm{F} \text {. Both full port and standard port configuration and screwed or tlanged } \\
\text { ends. }\end{array}$} \\
\hline \multicolumn{2}{|c|}{$\begin{array}{l}\text { BRIEF STATEMENT AS TO DEVELOPMENTAL AND TESTING CAPABILITIES } \\
\text { Life cycle, high and low temperature } 600^{\circ} \mathrm{F} \text { to } 325^{\circ} \mathrm{F} \text {. High pressure }(10,000 \text { psi) } \\
\text { vacuum, shell strength, stress testing. } \\
\text { Three engineers, } 33 \text { man years of ball valve experience. Rockwood marketed } \\
\text { first commercial ball valves, supplies many valves and components for US Navy. }\end{array}$} \\
\hline \multicolumn{2}{|c|}{$\begin{array}{l}\text { REMARKS: COMMEINTS OF FUTURE PRODUCT LINES THAT MAY BE AVAIIABLE BY 1982?, BY 1987? } \\
\text { 3/8"-8" top entry ball valves, carbon steel, stainless steel, screwed, SW, BW, } \\
150,300,600 \text { end configurations. High pressure/temp. butterfly valve. }\end{array}$} \\
\hline \multicolumn{2}{|c|}{$\begin{array}{l}\text { * LIST NAME AND ADDRESS AS YOU WOULD LIKE TO HAVE LISTED IN THE FINAL REPORT } \\
\text { Rockwood Systems Corporation } \\
80 \text { Second Street } \\
\text { So. Portland, ME } 04102\end{array}$} \\
\hline
\end{tabular}




\begin{tabular}{|l|c|c|}
\hline $\begin{array}{l}\text { FIRM NAME/ADDRESS/PHONE } \\
\text { Royal Industries }\end{array}$ & YEAR PRESENT FIRM ESTABLISHED & SURVEY DATE \\
$\begin{array}{l}\text { Energy Products Division } \\
2040 \text { East Dyer Road }\end{array}$ & 1957 & \\
$\begin{array}{l}\text { Santa Ana, California 92705 } \\
714-540-3210\end{array}$ & CONTACTS: NAME/TITLE/PHONE \\
\cline { 2 - 3 } & H. J. Fitzpatrick, VP-Mktg - 714-540-3210 \\
& J. P. Meredith, Dir. of Contract Adm. 714-540-3210
\end{tabular}

FORMER FIRM NAME, IF ANY, AND YEAR ESTABLISHED

Century Engineers, Inc.

Established 1949

PARENT COMPANY

Lear Siegler, Inc.

Santa Monica, CA 90406

\begin{tabular}{l|c|c}
\hline VALVE PLANT LOCATIONS & NUMBER OF EMPLOYEES & PLANT FLOOR SPACE: \\
Santa Ana, California & 600 & $320,000 \mathrm{sq} . \mathrm{ft}$.
\end{tabular}

BRIEF STATEMENT AS TO STANDARD VALVE PRODUCTS

Butterfly valves for cryogenic and petrochemical service, 150-pound and 300-pound rating, temperature range: $-320^{\circ} \mathrm{F}$ to $+400^{\circ} \mathrm{F}$. Standard sizes: $3^{\prime \prime}$ to $48^{\prime \prime}$, larger sizes available.

Ball valves for cryogenic and petrochemical service. 150-pound, 300-pound, 600-pound, and 900 -pound rating. Temperature range: $-320^{\circ} \mathrm{F}$ to $+400^{\circ} \mathrm{F}$. Standard sizes: $1 / 2^{\prime \prime}$ to $10^{\prime \prime}$.

BRIEF STATEMENT AS TO DEVELOPMENTAL AND TESTING CAPABILITIES

Engineering staff of 75 people. Includes stress analysis, testing, materials, electronics, and welding capabilities.

High temperature pressurized water facility: $+600^{\circ} \mathrm{F}, 2500 \mathrm{psi}$.

Cryogenic facility: $-320^{\circ} \mathrm{F}, 2000 \mathrm{psi}$.

REMARKS: COMMENTS OF FUIURE PRODUCT LINES THAT MAY BE AVAILABLE BY 1982?, BY 1987? High pressure, high temperature valves by 1985 .

* T.TST NAME AND ADDRESS $\Lambda$ S YOU WOULD LIKE TO ILAVE LIJTED IN THE F INAL REFUKT

Royal Industries

Energy Products Division

2040 East Dyer Road

Santa Ana, California 92705 


\begin{tabular}{|c|c|c|}
\hline \multirow{2}{*}{$\begin{array}{l}\text { FIRM NAME/ADDRESS/PHONE } \\
\text { Shan-Rod, Inc. } \\
\text { Driver Road } \\
\text { Berl in Heights, OH } \\
419-588-2066\end{array}$} & $\begin{array}{c}\text { YEAR PRESENT FIRM ESTABLISHED } \\
1970\end{array}$ & $\begin{array}{l}\text { SURVEY DATE } \\
7-26-77\end{array}$ \\
\hline & \multicolumn{2}{|c|}{$\begin{array}{l}\text { CONTACTS: NAME/TITLE/PHONE } \\
\text { Robert Rodwancy-Pres. (419) 588-2066 } \\
\text { David Hatala - Vice Pres. }\end{array}$} \\
\hline \multicolumn{3}{|c|}{$\begin{array}{l}\text { FORNER FIRM NAME, IF ANY, AND YEAR ESTABLISHED } \\
\text { None }\end{array}$} \\
\hline \multicolumn{3}{|l|}{$\begin{array}{l}\text { PARENT COMPANY - } \\
\text { None }\end{array}$} \\
\hline \multicolumn{3}{|c|}{\begin{tabular}{c|c} 
VALVE PLANT LOCATIONS & NUMBER OF EMPLOYEES \\
Berlin Heights, OH & 35
\end{tabular}} \\
\hline \multicolumn{3}{|c|}{$\begin{array}{l}\text { BRIEF STATEMENT AS TO STANDARD VALVE PRODUCTS } \\
\text { Design and manufacture all basic type valves including butterflys \& gates. Valve } \\
\text { designs for temperatures up to } 2400^{\circ} \mathrm{F} \text { and pressures not exceeding } 150 \text { psi. Sizes } \\
\text { range from } 4 " \text { to } 144^{\prime \prime} \text { round and } 20^{\prime} \times 30^{\prime} \text { rectangular. Build bubble tight and } \\
\text { swing through modulating types. }\end{array}$} \\
\hline \multicolumn{3}{|c|}{$\begin{array}{l}\text { BRIEF STATEMENT AS TO DEVELOPMENTAL AND TESTING CAPABILITIES } \\
\text { Perform all types of cycle/life testing. } \\
\text { Do hydrostatic and leakage testing. }\end{array}$} \\
\hline \multicolumn{3}{|c|}{$\begin{array}{l}\text { REMARKS: COMMENTS OF FUTURE PRODUCT LINES THAT MAY BE AVAILABLE BY 1982?, BY } 1987 ? \\
\text { No comment }\end{array}$} \\
\hline \multicolumn{3}{|c|}{$\begin{array}{l}\text { * LIST NAME AND ADDRESS AS YOU WOULD LIKE TO HAVE LISTED IN THE FINAL REPORT } \\
\text { Shan-Rod, Inc. } \\
\text { Driver Road } \\
\text { Berlin Heights, Ohio }\end{array}$} \\
\hline
\end{tabular}




\begin{tabular}{|c|c|c|}
\hline \multirow{2}{*}{$\begin{array}{l}\text { FIRM NAME/ADDRESS/PHONE } \\
\text { Sigmon Corporation } \\
4425 \text { Randolph Road } \\
\text { Charlotte, NC } 28211 \\
\text { (704) } 366-0766\end{array}$} & $\begin{array}{c}\text { YEAR PRESENT FIRM ESTABLISHED } \\
1973 \\
\end{array}$ & $\begin{array}{l}\text { SURVEY DATE } \\
8-15-77\end{array}$ \\
\hline & \multicolumn{2}{|l|}{$\begin{array}{l}\text { CONTACTS: NAME/TITLE/PHONE } \\
\text { James W. Sigmon, President } \\
(704) 366-0766 \text { or } 366-0767\end{array}$} \\
\hline \multicolumn{3}{|c|}{$\begin{array}{l}\text { FORMER F IRM NAME, IF ANY, AND YEAR ESTABLISHED } \\
\text { Sigmon Controls, Inc. (1968) }\end{array}$} \\
\hline \multicolumn{3}{|l|}{$\begin{array}{l}\text { PARENT COMPANY } \\
\text { Sigmon Corporation }\end{array}$} \\
\hline $\begin{array}{l}\text { VALVE PLANT LOCATIONS } \\
\text { Hampton, Virginia }\end{array}$ & \begin{tabular}{|r|r} 
BEER OF EMPLOYEES & PLAN \\
70 & 30,000 \\
\end{tabular} & $\begin{array}{l}\text { FLOOR SPACE } \\
\text { Sq. Ft. }\end{array}$ \\
\hline \multicolumn{3}{|c|}{$\begin{array}{l}\text { Expansible Seal Valve Series: A metal-to-metal sealing ball valve for application } \\
\text { to } 1500^{\circ} \mathrm{F} \text {. at pressures of up to } 6000 \text { PSIG. Available in ANSI Class ratings of } \\
150 \text { through } 2500 \text {. Sizes are } 1 " \text { through } 24^{\prime \prime} \text { with larger sizes for special appli- } \\
\text { cations. } \\
\text { Compression Seal Valve Series - A soft seated ball valve for application through } \\
550^{\circ} \mathrm{F} \text {. Available in ANSI Class ratings of } 150 \text { through } 2500 \text {. Sizes are } 1 " \text { through } \\
24^{\prime \prime} \text {. }\end{array}$} \\
\hline \multicolumn{3}{|c|}{$\begin{array}{l}\text { All applicable testings capabilities are available including } x \text {-ray, radiography, } \\
\text { and pressure and temperature testing. }\end{array}$} \\
\hline \multicolumn{3}{|c|}{$\begin{array}{l}\text { REMARKS: COMMENTS OF FUTURE PRODUCT LINES THAT MAY BE AVAILABLE BY 1982?, BY 1987? } \\
\text { AT though presently available in the ball configuration only, the Sigmon [xpansible } \\
\text { Seal valve design will likely be available in the butterfly, gate and globe con- } \\
\text { figurations by } 1982 \text {. By } 1987 \text {, the company anticipates broadening its market with } \\
\text { other products utilizing the proprietary Expansible Seal components. These } \\
\text { products would likely be closures, lock hoppers, large filtration systems and } \\
\text { reactor feeders. }\end{array}$} \\
\hline \multicolumn{3}{|c|}{$\begin{array}{l}\text { * LIST NAME AND ADDRESS AS YOU WOULD LIKE TO HAVE LISTED IN THE FINAL REPORT } \\
\text { Sigmon Corporation } \\
4425 \text { Randolph Road } \\
\text { Charlotte, NC } 28211\end{array}$} \\
\hline
\end{tabular}




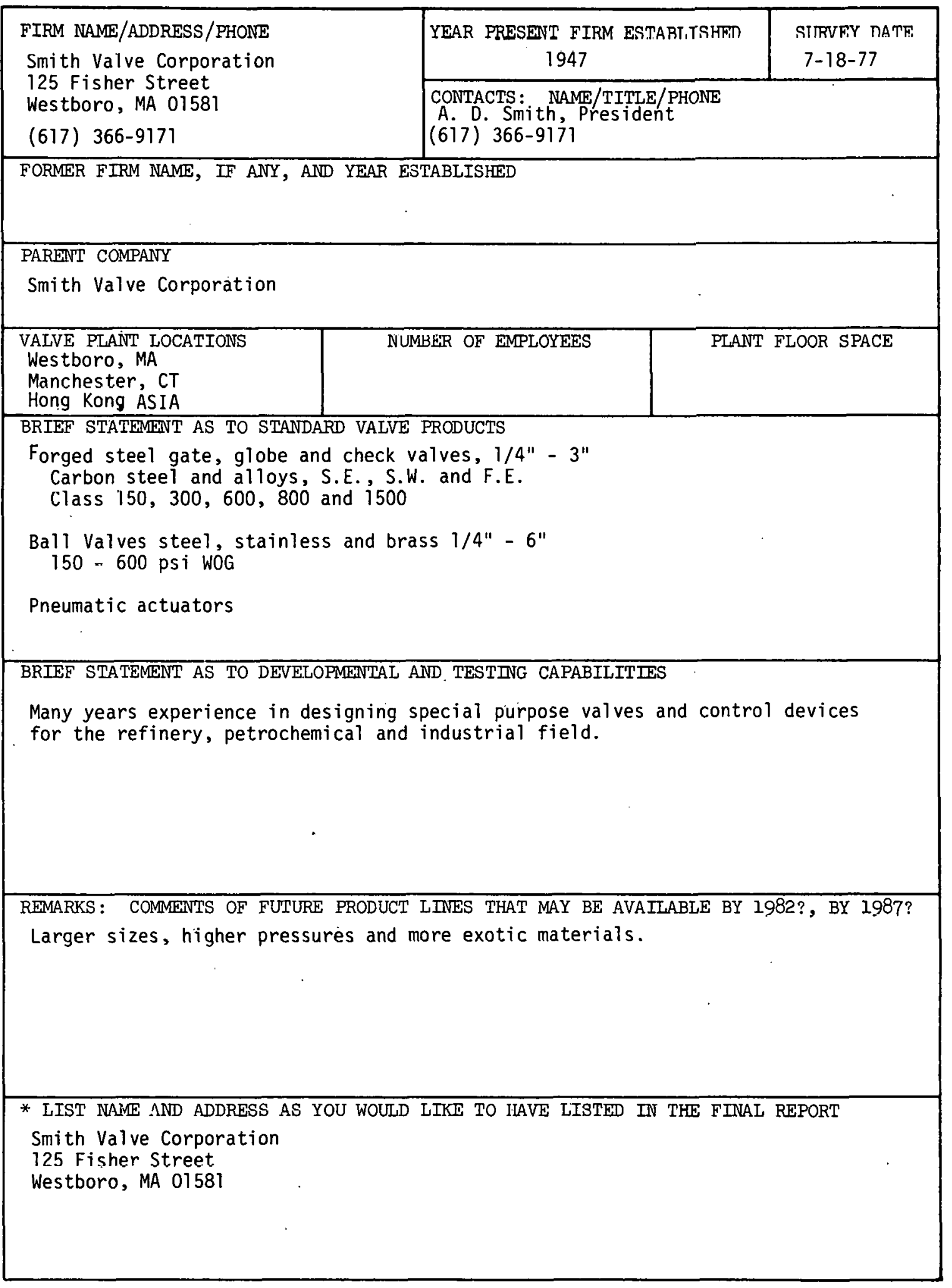




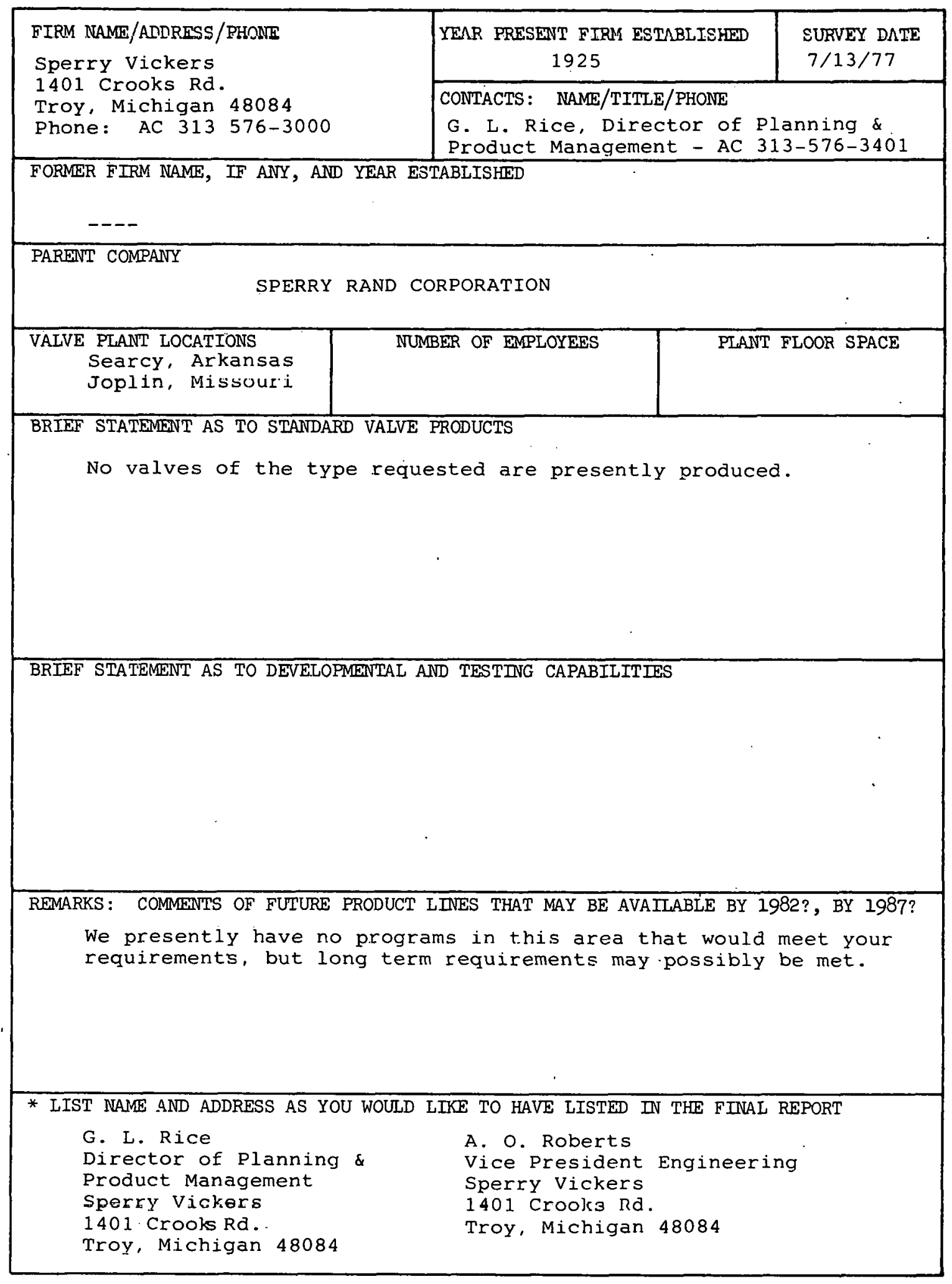




\begin{tabular}{|c|c|}
\hline \multirow{2}{*}{$\begin{array}{l}\text { FIRM NAME/ADDRESS/PHONE } \\
\text { Stockham Valves \& Fittings } \\
\text { Box } 10326 \\
\text { Birmingham, Alabama } 35202 \\
\text { Phone: (205) 592-6361. }\end{array}$} & \begin{tabular}{c|c} 
YEAR PRESENT FIRM ESTABLISHED & SURVEY DATE \\
1903 & $6-30-77$
\end{tabular} \\
\hline & $\begin{array}{l}\text { CONTACTS: NAME/TITLE/PHONE } \\
\text { S. J. POSS, Vice-President - Sales } \\
(205) \text { 592-6361 }\end{array}$ \\
\hline \multicolumn{2}{|c|}{ FORMER FIRM NAME, IF ANY, AND YEAR ESTABLISHED } \\
\hline PAREINT COMPANY & $\begin{array}{llll} & & & \\
& & & \\
& \cdots & \\
& & \\
\end{array}$ \\
\hline $\begin{array}{l}\text { VALVE PLANT LOCATIONS } \\
\text { Birmingham, Alabama }\end{array}$ & \begin{tabular}{l|r} 
BER OF EMPLOYEES & PLANT FLOOR SPACE \\
2,300 & $-842,333 \mathrm{Sq} . \mathrm{Ft}$. \\
\end{tabular} \\
\hline \multicolumn{2}{|c|}{$\begin{array}{l}\text { BRIEF STATEMENT AS TO STANDARD VALVE PRODUCTS } \\
\text { Industrial type valves, Bronze, Classes } 125,150,200 \text { and } 300 \text {, Gate, Globe, Angle, } \\
\text { and Check, - Cast Iron, Classes } 125 \text { and } 250 \text { Gate, Globe, Angle, and Check, Ductile } \\
\text { Iron, Classes } 150 \text { and } 300 \text { Gate, Globe and Check, - Stee } 1, \text { Classes } 150 ; 300 \text { and } \\
600 \text { Gate, Globe, Angle, Check; Steel Wedgeplug-Classes } 150,300 \text { and } 600 ; \text { Cast Iron } \\
\text { and Ductile Wafer Butterfly, Sizes } 1 / 4 \text { through } 36 \text { inches. }\end{array}$} \\
\hline \multicolumn{2}{|c|}{$\begin{array}{l}\text { BRIEF STATEMENT AS TO DEVELOPMENTAL AND TESTING CAPABILITIES } \\
\text { We have competent engineers to develop the design and test the prototype. The } \\
\text { testing capabilities consist of pneumatic, hydrostatic, and steam test, plus } \\
\text { chemical and metallurgical laboratory. }\end{array}$} \\
\hline \multicolumn{2}{|c|}{ REMARKS: COMMENTS OF FUTURE PRODUCT LINES THAT MAY BE AVAIILABLE BY 1982?, BY 1987? } \\
\hline \multicolumn{2}{|c|}{ Enlarged size range and pressure class steel valves. } \\
\hline $\begin{array}{l}\text { * LIST NAME AND ADDRESS AS } \\
\text { Stockham Valves \& Fittings } \\
\text { Box } 10326 \\
\text { Birmingham, Alabama } 35202\end{array}$ & LIKE TO HAVE LISTED IN THE FINAL REPORT. \\
\hline
\end{tabular}




\begin{tabular}{|c|c|c|}
\hline \multirow{2}{*}{$\begin{array}{l}\text { FIRM NAME/ADDRESS/FHONE } \\
\text { Sulzer Bros., Inc. } \\
19 \text { Rector Street } \\
\text { New York, New York } 10006\end{array}$} & 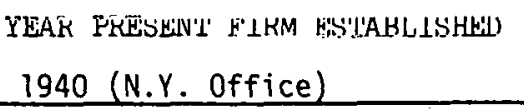 & $\begin{array}{l}\text { SURVEY DA'IE } \\
\text { JuTY } 19, \quad 1977\end{array}$ \\
\hline & \multicolumn{2}{|c|}{$\begin{array}{l}\text { CONTACTS: NAME/TITLE/PHONE FTS:212-425-4560 } \\
\text { Wal ter P. Gadient, Manager } \\
\text { Power Plant Components Division }\end{array}$} \\
\hline \multicolumn{3}{|c|}{ FORMER FIRM NAME, IF ANY, AND YEAR ESTABLISHED } \\
\hline \multicolumn{3}{|c|}{$\begin{array}{l}\text { PARENT COMPANY } \\
\text { Founded } 1834 \\
\text { Sulzer Brothers Limited, } \mathrm{CH}-8401 \text { Winterthur, Switzerland }\end{array}$} \\
\hline $\begin{array}{l}\text { VALVE PLANT LOCATIONS } \\
\text { Winterthur, Switzerland }\end{array}$ & $\begin{array}{l}\text { BER OF' EMPLOYEES } \\
511 \text { Total }\end{array}$ & $\begin{array}{l}\text { FLOOR SPACE } \\
\text { DOO Sq. Ft. }\end{array}$ \\
\hline \multicolumn{3}{|c|}{$\begin{array}{l}\text { BRIET STATEMENT AS TO STANDARD VALVE PRODUCTS } \\
\text { SUlzer standard valves, actuators and positioning controls are designed for high } \\
\text { pressure, high temperature applications with high requirements of flow control. } \\
\text { The given requirements, from a pressure and temperature point of view, are well } \\
\text { within our standard valve capabilities. The required sizes also can be considered } \\
\text { standard. The solids content of the medium is new; however, it appears to be } \\
\text { manageable. }\end{array}$} \\
\hline \multicolumn{3}{|c|}{$\begin{array}{l}\text { BRIEF STATEMENT AS TO DEVELOPMENTAL AND TESTING CAPABILITIES } \\
\text { Sulzer's activity in high pressure, high temperature valve applications required } \\
\text { from the beginning a high development and testing capability. Therefore, we } \\
\text { feel well qualified to satisfy these requirements. }\end{array}$} \\
\hline \multicolumn{3}{|c|}{$\begin{array}{l}\text { REMARKS: COMMENTS OF FUTURE FRODUCT INES THAT MAY BE AVAILABLE BY 1982", BY 1987? } \\
\text { Large valves (valve materials) for handi ing high temperature gases and requiring } \\
\text { fast closure and/or modulating exceeding the required data may be available in } \\
1982 \text {, as well as improved seat materials for still higher tightness and durability. }\end{array}$} \\
\hline \multicolumn{3}{|c|}{$\begin{array}{l}\text { * LIST NAME AND ADDRESS AS YOU WOULD LIKE TO HAVE LISTED IN THE FINAL REPORT } \\
\text { Sulzer Bros., Inc. } \\
\text { 19 Rector Street } \\
\text { New York, New York } 10006 \\
\text { Walter P. Gadient }\end{array}$} \\
\hline
\end{tabular}




\begin{tabular}{|c|c|c|}
\hline \multirow{2}{*}{$\begin{array}{l}\text { FIRM NAME/ADDRESS/PHONE } \\
\text { TAPCO International, Inc. } \\
\text { 14309. Sommermeyer } \\
\text { P. O. Box } 40472 \\
\text { Houston, TX } 77040 \\
\text { (713) } 460-0300 \text {, Telex } 76-2139\end{array}$} & $\begin{array}{c}\text { YEAR PRESENT FIRM ESTABLISHED } \\
1946\end{array}$ & $\begin{array}{l}\text { SURVEY DATE } \\
7 / 19 / 77\end{array}$ \\
\hline & $\begin{array}{l}\text { CONTACTS: NAME/TITLE/PHONE } \\
\text { Ms. Victoria Kaminski, Contrac } \\
\text { (7i 3) } 460-0300\end{array}$ & Administrator \\
\hline \multicolumn{3}{|c|}{$\begin{array}{l}\text { FORMER FIRM NAME, IF ANY, AND YEAR ESTABLISHED } \\
\text { Texas Alloy Products Company, } 1946\end{array}$} \\
\hline \multicolumn{3}{|l|}{$\begin{array}{l}\text { PARENT COMPANY } \\
\text { None }\end{array}$} \\
\hline \begin{tabular}{l|l} 
VALVE PLANT LOCATIONS & \\
Houston, Texas &
\end{tabular} & \begin{tabular}{l|r} 
BER OF EMPLOYEES & PLAN \\
287 & 64,
\end{tabular} & $\begin{array}{l}\text { FIOOR SPACE } \\
0 \text { Sq. Ft. }\end{array}$ \\
\hline \multicolumn{3}{|c|}{$\begin{array}{l}\text { BRIEF STATEMENT AS TO STANDARD VALVE PRODUCTS } \\
\text { TAPCO is a speciality valve manufacturer where each valve is designed for the } \\
\text { individual process application. No valve catalog items exist. }\end{array}$} \\
\hline \multicolumn{3}{|c|}{$\begin{array}{l}\text { BRIEF STATEMENT AS TO DEVELOPMENTAL AND TESTING CAPABILITIES } \\
\text { TAPCO does not have facilities which provide consistent flow capabilities needed } \\
\text { in the developmental or testing of valves. }\end{array}$} \\
\hline \multicolumn{3}{|c|}{$\begin{array}{l}\text { REMARKS: COMMENTS OF FUTURE PRODUCT LINES THAT MAY BE AVAIILABLE BY 1982?, BY 1987? } \\
\text { TAPCO has patents on valves that are applicable to the coal gasification processes. } \\
\text { TAPCO also is pursuing all current processes in an effort to stay up-to-date on } \\
\text { the state of the art. TAPCO intends to provide a continuing program aimed at the } \\
\text { coal gasification industry. This will be accomplished by updating current patents } \\
\text { and development of new valve designs as the process information comes available. }\end{array}$} \\
\hline \multicolumn{3}{|c|}{$\begin{array}{l}\text { * LIST NAME AND ADDRESS AS YOU WOULD LIKE TO HAVE L.TSTED IN THE FINAL REPORT } \\
\text { TAPCO International, Inc. } \\
1430 \text { Sommermeyer } \\
\text { P. } 0 \text {. Box } 40472 \\
\text { Houston, TX } 77040\end{array}$} \\
\hline
\end{tabular}




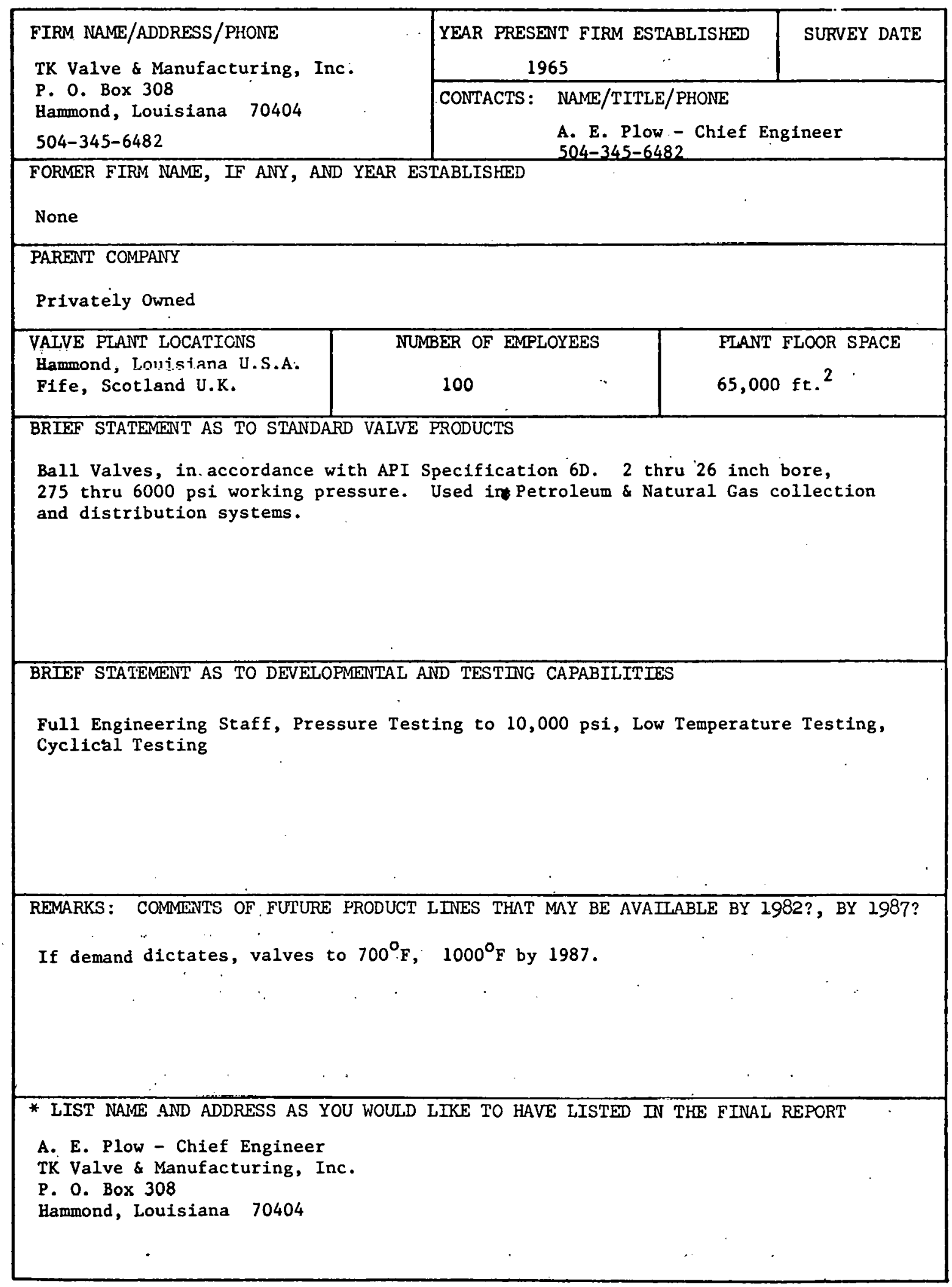




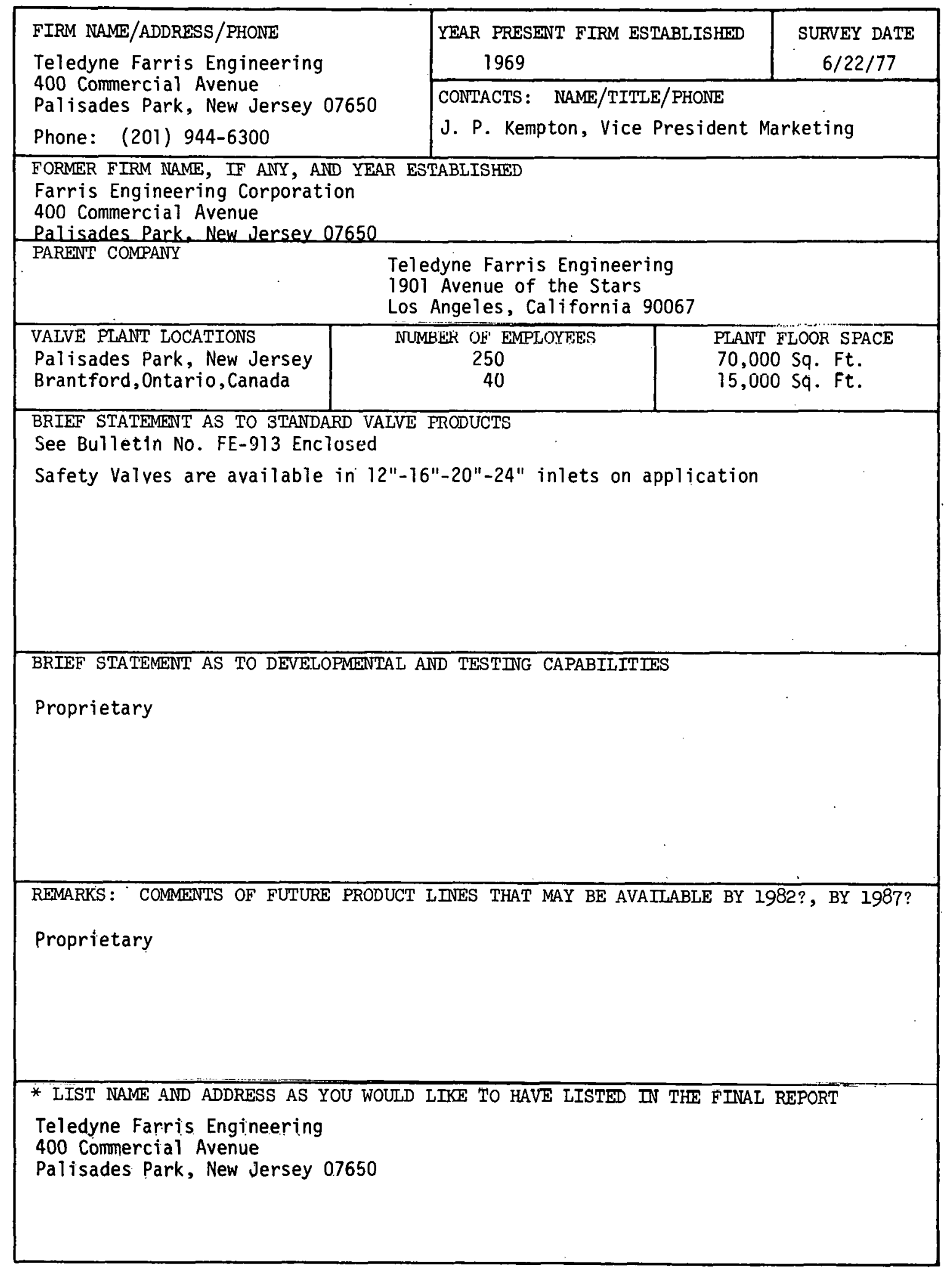




\begin{tabular}{|c|c|c|}
\hline \multirow{2}{*}{$\begin{array}{l}\text { FIRM NAME/ADDRESS/PHONE } \\
\text { Tufline Div., Xomox } \\
4444 \text { Cooper Road } \\
\text { Cincinnati, Ohio } 45242 \\
\text { (513) } 793-7000\end{array}$} & $\begin{array}{l}\text { YEAR PRESENT FIRM ESTABLISHED } \\
1956 \\
\end{array}$ & $\begin{array}{l}\text { SURVEY DATE } \\
\text { May, } 1977\end{array}$ \\
\hline & \multicolumn{2}{|c|}{$\begin{array}{l}\text { CONIACTS: NAME/TITLE/PHONE } \\
\text { Russell Smith, Vice President, Manager Power } \\
\text { Industry Products/(513) } 793-7000\end{array}$} \\
\hline \multicolumn{3}{|c|}{$\begin{array}{l}\text { FORMER FIRM NAME, IF ANY, AND YEAR ESTABLISHED } \\
\text { Continental Manufacturing Company, } 1956\end{array}$} \\
\hline \multicolumn{3}{|l|}{$\begin{array}{l}\text { PARENT COMPANY } \\
\text { Not Applicable }\end{array}$} \\
\hline $\begin{array}{l}\text { VALVE PLANT LOCATIONS } \\
4444 \text { Cooper Road } \\
\text { Cincinnati, OH }\end{array}$ & \begin{tabular}{l|r} 
BER OF EMPLOYEES & PLAN \\
460 & 100,0 \\
\end{tabular} & $\begin{array}{l}\text { LOOR SPACE } \\
\text { Sq. Ft. }\end{array}$ \\
\hline \multicolumn{3}{|c|}{$\begin{array}{l}\text { BRIEF STATEMENT AS TO STANDARD VALVE PRODUCTS } \\
\text { Non-lubricated tapered sleeved type plug valves; butterfly valves; actuators } \\
\text { and plug control valves. }\end{array}$} \\
\hline \multicolumn{3}{|c|}{$\begin{array}{l}\text { BRIEF STATEMENT AS TO DEVELOPMENTAL AND TESTING CAPABILITIES } \\
\text { We have air, hydrostatic and some steam and cycle testing capabilities. We have } \\
\text { a relatively large Research and Development staff and have designed a valve } \\
\text { which we think would be particularly applicable for the pressures and temperatures } \\
\text { and slurry service involved. We note that you mention ball type valves may be } \\
\text { utilized. We believe this is a mistake due to the pocketing characteristics of } \\
\text { ball valves. We are most interested in discussing the possibility of producing } \\
\text { a prototype valve for the services involved. }\end{array}$} \\
\hline \multicolumn{3}{|c|}{$\begin{array}{l}\text { REMARKS: COMMENTS OF FUTURE PRODUCT LINES THAT MAY BE AVAIIABLE BY 1982?, BY } 1987 ? \\
\text { We expect to have a full line of high pressure/high temperature metal scatcd } \\
\text { valves by } 1982 \text {. }\end{array}$} \\
\hline \multicolumn{3}{|c|}{$\begin{array}{l}\text { * LIST NAME AND ADDRESS AS YOU WOULD LIKE TO HAVE LISTED IN THE FINAL REPORT } \\
\text { C. L. Reed, Xomox Corporation, } 4444 \text { Cooper Road, Cincinnati, OH } 45254 \\
\text { F. A. Godley, Xomox Corporation, } 733 \text { Summer Street, Stamford, CT } 06902 \\
\text { Russell G. Smith, Xomon Corporation, } 4444 \text { Cooper Road, Cincinnati, OH } 45242 \\
\text { Paul Trautman, Xomox Corporation, } 4444 \text { Cooper Road, Cincinnati, OH } 45242\end{array}$} \\
\hline
\end{tabular}




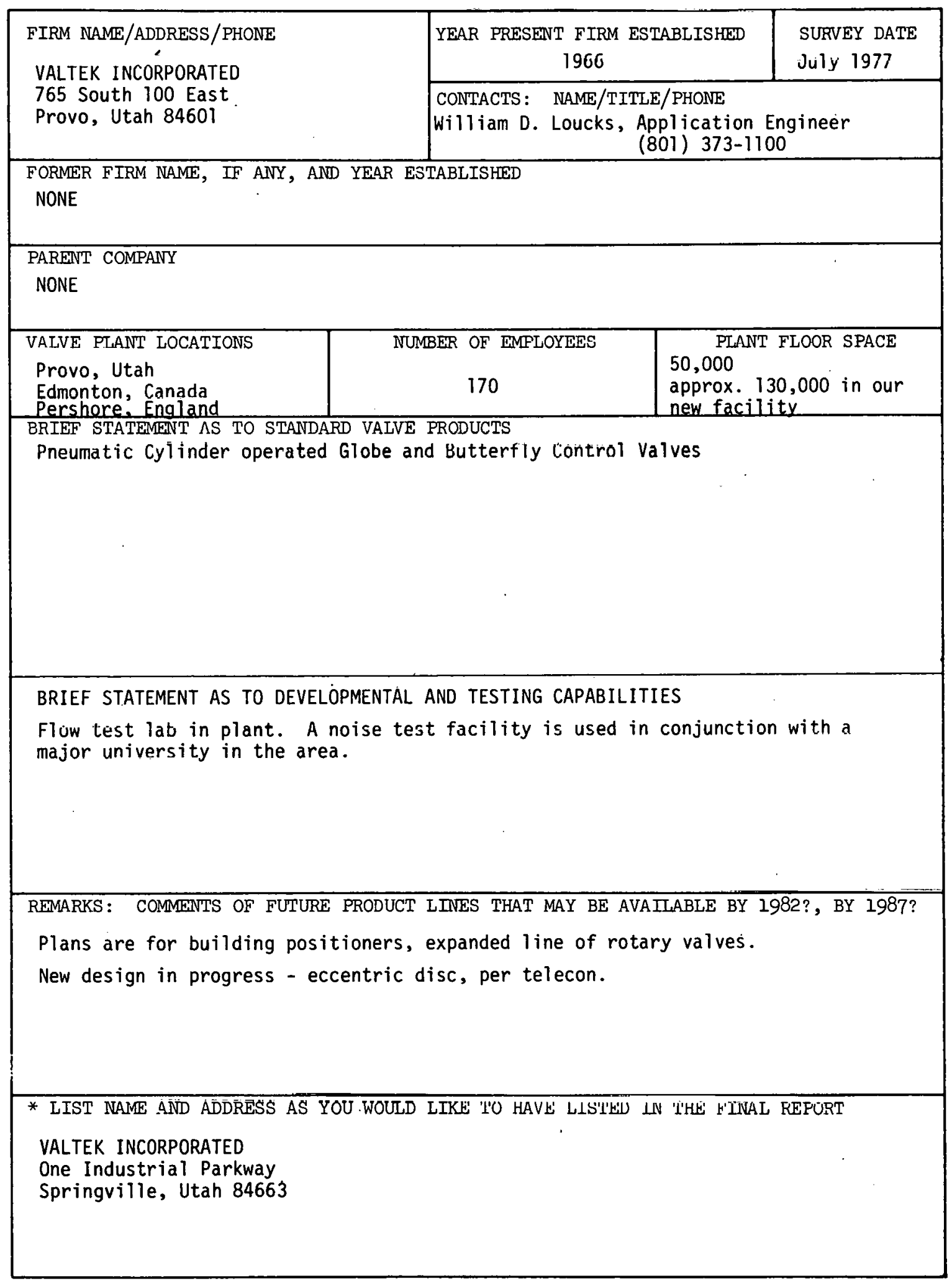




\begin{tabular}{|c|c|c|}
\hline \multirow{2}{*}{$\begin{array}{l}\text { FIRM NAME/ADDRESS/PHONE } \\
\text { WALWORTH COMPANY } \\
\text { P.O. BOX } 873 \\
\text { Valley Forge, Pa. } 19482 \\
\text { (215) } 337-3500\end{array}$} & $\begin{array}{c}\text { YEAR PRESENT FIRM ESTABLISHED } \\
1846\end{array}$ & $\begin{array}{l}\text { SURVEY DATE } \\
7 / 1 / 77\end{array}$ \\
\hline & \multicolumn{2}{|c|}{$\begin{array}{l}\text { CONTACTS: NAME/TITLE/PHONE } \\
\text { William H. HOpf, V.P. Engineering } \\
\text { (2is) 337-3500 x } 216\end{array}$} \\
\hline \multicolumn{3}{|c|}{$\begin{array}{l}\text { FORMER FIRM NAME, IF ANY, AND YEAR ESTABLISHED } \\
\text { None }\end{array}$} \\
\hline \multicolumn{3}{|c|}{$\begin{array}{l}\text { PARENT COMPANY } \\
\text { ANACONDA CO., subsidiary Of ATLANTIC RICHFIELD CO. }\end{array}$} \\
\hline \multicolumn{3}{|c|}{ 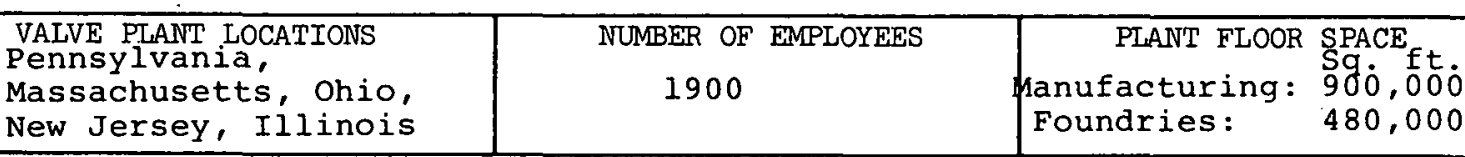 } \\
\hline \multicolumn{3}{|c|}{$\begin{array}{l}\text { BRIEF STATEMENT AS TO STANDARD VALVE PRODUCTS } \\
\text { Walworth manufactures Gate, Globe, Check and Plug valves for the CPI, } \\
\text { HPI, Power Generation and Marine Industries. Service ranges from } \\
\text { vacuum to ANSI Class } 2500 \text {, and from cryogenic temperatures to } 1500^{\circ} \mathrm{F} \text {. } \\
\text { Standard materials are Steel, Steel Alloys, Austenitic Steels, the } \\
\text { iron family, copper alloys, and nickel alloys. }\end{array}$} \\
\hline \multicolumn{3}{|c|}{$\begin{array}{l}\text { BRIEF STATEMENT AS TO DEVELOPMENTAL AND TESTING CAPABILITIES } \\
\text { Our development and testing facilities consist of the following } \\
\text { capabilities: Engineers: } 14 \text { graduate engineers with more than } \\
175 \text { years of valving know-how. Flow Loops--gas flow testing to } 4 " \\
\text { valve size, and water to } 14 " \text { valve size with continuous } 6000 \text { GPM flow. } \\
\text { steam Testing--1500 psi saturated. Pressure Testing to } 20,000 \text { psi. } \\
\text { Temperature from }-250^{\circ} \text { to } 2000^{\circ} \text {. Mechanical--Simulated pipe bending, } \\
\text { all modes. Cycle Tests--under ail load, pressure, and temperature } \\
\text { conditions. Inspection and complete metallographic evaluation. }\end{array}$} \\
\hline \multicolumn{3}{|c|}{$\begin{array}{l}\text { REMARKS: COMMENTS OF FUTURE PRODUCT LINES THAT MAY BE AVAIIABLE BY 1982?, BY 1987? } \\
\text { Walworth is currently developing a high temperature seating concept } \\
\text { capable of sealing against abrasive slurries and extreme fines at } \\
\text { pressures to ANSI class } 2500 \text { and to } 1500^{\circ} \mathrm{F} \text {. Its application can be } \\
\text { for either } \frac{1}{4} \text { turn or multi-turn valve types. Prototypes are planned } \\
\text { for completion in } 1978 \text { and a product line availability for } 1980 \text {. } \\
\text { walworth is interested in and capable of developing valves for coal } \\
\text { conversion. We will be pleased to work with others in such a develop- } \\
\text { ment effort, to produce the required valves by } 1982 \text { and/or } 1987 \text {. }\end{array}$} \\
\hline \multicolumn{3}{|c|}{$\begin{array}{l}\text { * LIST NAME AND ADDRESS AS YOU WOULD LIKE TO HAVE LISTED IN THE FINAI REPORT } \\
\text { President: Norman Schoenfeld } \\
\text { Vice President Engineering: William H. Hopf } \\
\text { Address: P.O. Box } 873 \text { (74i First Ave.) } \\
\text { Valley Forge, Pa. } 19482\end{array}$} \\
\hline
\end{tabular}




\begin{tabular}{|c|c|c|c|}
\hline \multirow{2}{*}{$\begin{array}{l}\text { FIRM NAME/ADDRESS/PHONE } \\
\text { Watts Regulator Company } \\
10 \text { Embankment St. } \\
\text { Lawrence, Massachusetts } 01842\end{array}$} & \multicolumn{2}{|c|}{$\begin{array}{c}\text { YEAR PRESENT FIRM ESTABLISHED } \\
1075\end{array}$} & $\begin{array}{r}\text { SURVEY DATE } \\
\text { July 13, } 1977\end{array}$ \\
\hline & \multicolumn{3}{|c|}{ CONTACTS: NAME/TITLE/PHONE } \\
\hline \multicolumn{4}{|c|}{ FORNER FIRM NAME, IF ANY, AND YFAR ESTABLISHED } \\
\hline \multicolumn{4}{|l|}{$\begin{array}{l}\text { PARENT' COMPANY } \\
\text { Same }\end{array}$} \\
\hline \begin{tabular}{l|l} 
VALVE PLANT LOCATIONS & \\
Lawrence, MA & \\
Frankl in, NH & \\
Kittery, ME & \\
\end{tabular} & $\begin{array}{l}\text { BER OF EMPLOYEES } \\
1200\end{array}$ & $\begin{array}{l}\text { PLAN } \\
12 \text { Acre: }\end{array}$ & $\begin{array}{l}\text { U'LUUK SFACE } \\
\text { Under Roof }\end{array}$ \\
\hline \multicolumn{4}{|c|}{$\begin{array}{l}\text { BRIEF STATEMENT AS TO STANDARD VALVE PRODUCTS } \\
\text { See Attached Catalogs U-75B, } 628 F \\
\text { Automatic Temperature-Pressure Safety and Regulating Valves and Backflow Prevention } \\
\text { Uevices } \\
\text { Fluid Power Pneumatic Regulators, Filters and Lubricators }\end{array}$} \\
\hline \multicolumn{4}{|c|}{$\begin{array}{l}\text { BRIEF STATEMENT AS TO DEVELOPMENTAL AND TESTING CAPABILITIES } \\
\text { R\&D limited to water, steam and air safety and control devices. }\end{array}$} \\
\hline \multicolumn{4}{|c|}{$\begin{array}{l}\text { REMARKS: COMMENTS OF FUTURE PRODUCT LINES THAT MAY BE AVAILABLE BY 1982?, BY } 1987 ? \\
\text { Same valve field for different applications. }\end{array}$} \\
\hline \multicolumn{4}{|c|}{$\begin{array}{l}\text { * LIST NAME AND ADDRESS AS YOU WOULD LIKE TO HAVE LISTED IN THE FINAL REPOK'I' } \\
\text { Watts Regulator Co. } \\
10 \text { Embankment St. } \\
\text { Lawrence, MA } 01842\end{array}$} \\
\hline
\end{tabular}




\begin{tabular}{|c|c|c|}
\hline \multirow{2}{*}{$\begin{array}{l}\text { FIRM NAME/ADDRESS/PHONE } \\
\text { Westinghouse Electric Corporation } \\
\text { Electro-Mechanical Division } \\
\text { Cheswick Avenue } \\
\text { Cheswick, PA } 15024\end{array}$} & $\begin{array}{l}\text { YEAR PRESENT FIRM ESTABLISHED } \\
1952\end{array}$ & $\begin{array}{l}\text { SURVEY DATE } \\
7 / 13 / 77\end{array}$ \\
\hline & \multicolumn{2}{|c|}{$\begin{array}{l}\text { CONTACTS: NAME/TITLE/PHONE } \\
\text { H. E. Eminger, Mfgr., Valve Engineering } \\
\text { Area Code } 412274-6300 \quad X-131\end{array}$} \\
\hline \multicolumn{3}{|c|}{$\begin{array}{l}\text { FORMER FIRM NAME, IF ANY, AND YEAR ESTABLISHED } \\
\text { None }\end{array}$} \\
\hline \multicolumn{3}{|l|}{$\begin{array}{l}\text { PARENT COMPANY } \\
\text { Westinghouse Electric Corporation }\end{array}$} \\
\hline \multicolumn{2}{|c|}{\begin{tabular}{l|c} 
VALVE PLANT LOCATIONS & NUMBER OF EMPLOYEES \\
Cheswick, PA & 190
\end{tabular}} & $\begin{array}{l}\text { PLANT FLOOR SPACE } \\
75,000 \mathrm{Sq} . \mathrm{Ft} .\end{array}$ \\
\hline \multicolumn{3}{|c|}{$\begin{array}{l}\text { BRIEF STATEMENT AS TO STANDARD VALVE PRODUCTS } \\
\text { Wedge Gate Valves; Manual and Motor Operated; Swing Check Valves; all Stainless } \\
\text { Steel, designed and manufactured to ASME, Section III, Class } 1,2,3 \text { requirements } \\
\text { for commercial nuclear power plant applications. Valve sizes range from three to } \\
18 \text { inches. Also, } 27.5 \text { and } 29 \text {-inch parallel Gate Motor Operated Stainless Steel } \\
\text { Valves for primary loop isolation in pressurized water reactors. }\end{array}$} \\
\hline \multicolumn{3}{|c|}{$\begin{array}{l}\text { BRIEF STATEMENT AS-TO DEVELOPMENTAL AND TESTING CAPABILITIES } \\
\text { Broad range developmental and test capabilities available within the Corporation. } \\
\end{array}$} \\
\hline \multicolumn{3}{|c|}{$\begin{array}{l}\text { REMARKS: COMMENTS OF FUTURE PRODUCT LINES THAT MAY BE AVAILABLE BY 1982?, BY 1987? } \\
\text { None presently planned. }\end{array}$} \\
\hline \multicolumn{3}{|c|}{$\begin{array}{l}\text { * LIST NAME AND ADDRESS AS YOII WOIIL LIKE TO HAVE LICTED IN THE FINAL REPUKT } \\
\text { Westinghouse Electric Corporation } \\
\text { Electro-Mechanical Division } \\
\text { Cheswick Avenue } \\
\text { Cheswick, PA } 15024\end{array}$} \\
\hline
\end{tabular}




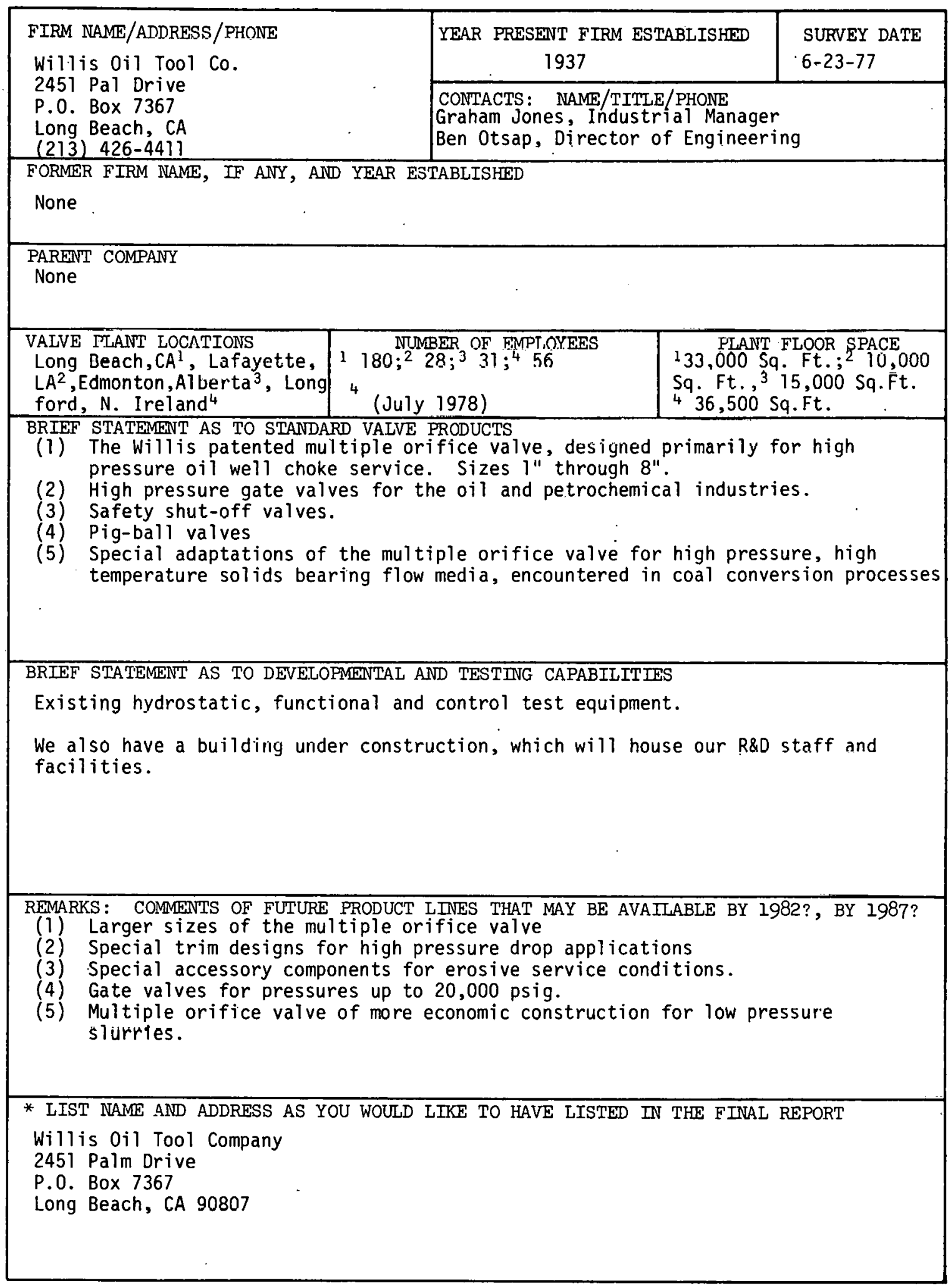




\begin{tabular}{|c|c|c|}
\hline \multirow{2}{*}{$\begin{array}{l}\text { FIRM NAME/ADDRESS/PHONE } \\
\text { Worcester Controls Corporation } \\
125 \text { Hartwe11 Street } \\
\text { W. Boylston, MA } 01583 \\
(617) 835-6041\end{array}$} & $\begin{array}{c}\text { YEAR PRESENT FIRM ESTABLISHED } \\
1955\end{array}$ & $\begin{array}{l}\text { SURVEY DATE } \\
9-2-77\end{array}$ \\
\hline & \multicolumn{2}{|l|}{$\begin{array}{l}\text { CONTACTS: NAME/TITLE/PHONE } \\
\text { R. C. Boedecker, Sales Manager }\end{array}$} \\
\hline \multicolumn{3}{|c|}{$\begin{array}{l}\text { FORMER FIRM NAME, IF ANY, AND YEAR ESTABLISHED } \\
\text { None }\end{array}$} \\
\hline \multicolumn{3}{|c|}{$\begin{array}{l}\text { PAREIVT COMPANY } \\
\text { None }\end{array}$} \\
\hline $\begin{array}{l}\text { VALVE PLANT LOCATIONS } \\
\text { Londonderry, NH - Haywards } \\
\text { Hudson, MA Heath, UK } \\
\text { W. Boyiston, MA Scarborough } \\
\text { W Or }\end{array}$ & \begin{tabular}{l|r} 
BER OF EMPLOYEES & PLAN \\
SA $=280$ & USA $=$ \\
Canada & \\
\end{tabular} & $\begin{array}{l}\text { LOOR SPACE } \\
, 000\end{array}$ \\
\hline \multicolumn{3}{|c|}{$\begin{array}{l}\text { BRIEF STATEMENT AS TO STANDARD VALVE PRODUCTS } \\
1 / 4^{\prime \prime}-8^{\prime \prime} \text { ball valves with soft seats, electric and pneumatic rotary actuators and } \\
\text { controls for them. Pressure ratings from high vacuum to } 5,000 \text { psig dependent on } \\
\text { size and temp. Temp. ratings from }-350^{\circ} \mathrm{F} \text { to }+600^{\circ} \mathrm{F} \text { dependent on size, pressure, } \\
\text { and media. }\end{array}$} \\
\hline \multirow{2}{*}{\multicolumn{3}{|c|}{$\begin{array}{l}\text { BRIEF STATEMENT AS TO DEVELOPNENTAL AND TESTING CAPABIIITIES } \\
\text { (12) people in prod. dev. engineering department in a project engineering struc- } \\
\text { ture. Can handle } 5-6 \text { new development projects per year dependent on priority and } \\
\text { degree of difficulty. } \\
\text { Have an in-plant lab for basic testing requirements to } 1,000^{\circ} \mathrm{F} \text { ambient, } 225 \mathrm{psig} \\
\text { steam, flows of water and cryogens, and high static pressures. Have arrangements } \\
\text { with local independent testing labs for more severe test requirements. }\end{array}$}} \\
\hline & & \\
\hline \multicolumn{3}{|c|}{$\begin{array}{l}\text { REMARKS: COMMENTS OF FUTURE PRODUCT LINES THAT MAY BE AVAILABLE BY 1982?, BY 1987? } \\
\text { Efforts seem aimed at further dcvelopment of dcluation and control capability. } \\
\text { Exploration of digital controls is continuing. New alloys and higher pressure } \\
\text { temp. rating for valves are being tested. }\end{array}$} \\
\hline \multicolumn{3}{|c|}{ * LIST NAME $\Lambda$ ND ADDRESS AS YOU WOULDD LIKE I'O HAVE LISTED IN THL FLNAL REPORT } \\
\hline
\end{tabular}




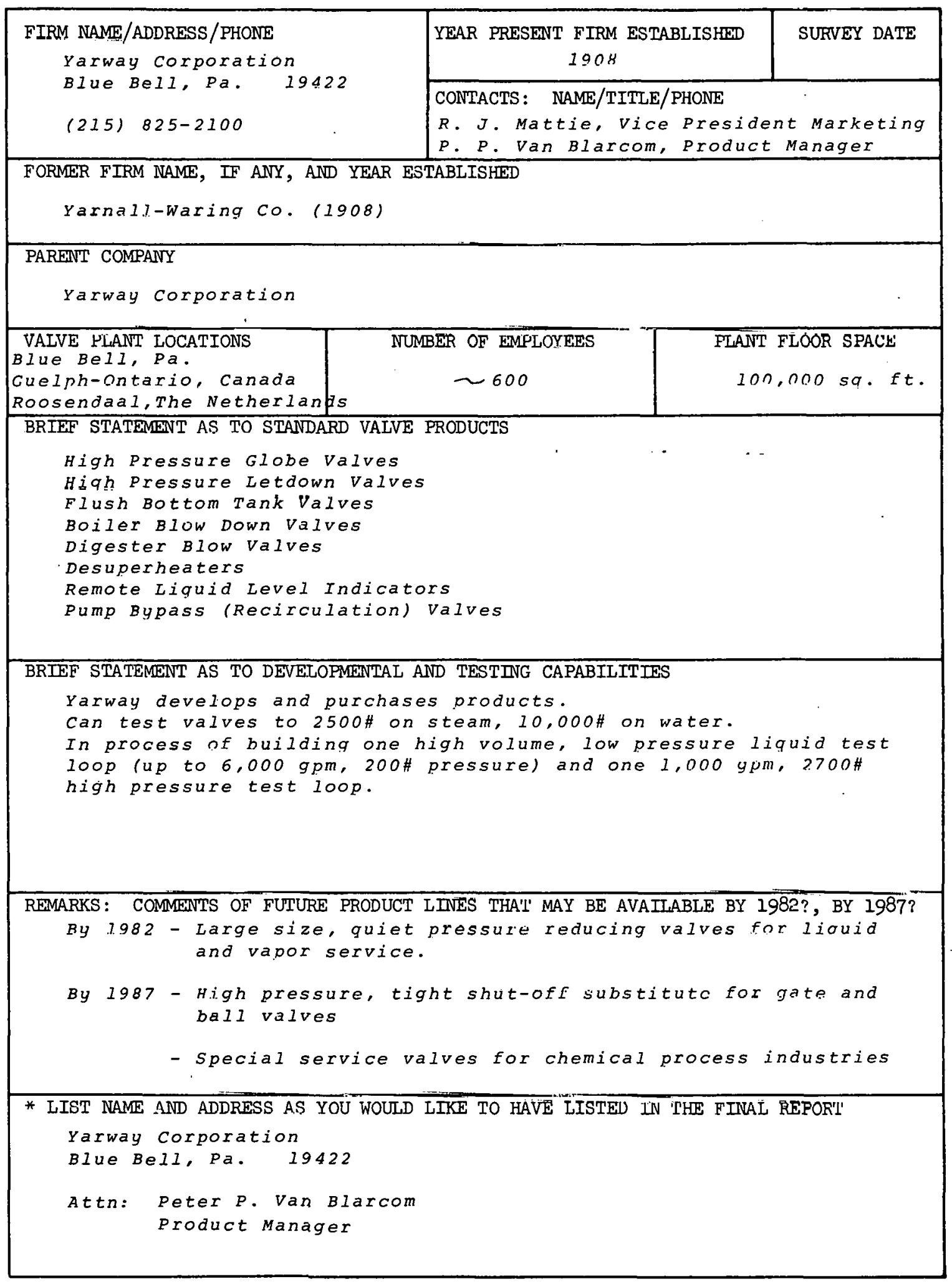




\begin{tabular}{|c|c|c|}
\hline \multirow{2}{*}{$\begin{array}{l}\text { FIRM NAME/ADDRESS/PHONE } \\
\text { Zidell Valve Division } \\
3121 \text { S. W. Moody Ave. } \\
\text { Portland, OR } 97201 \\
\text { (503) } 228-8691\end{array}$} & $\begin{array}{l}\text { YEAR PRESENT FIRM ESTABLISHED } \\
\qquad 1 / 31 / 52\end{array}$ & $\begin{array}{l}\text { SURVEY DATE } \\
7 / 11 / 77\end{array}$ \\
\hline & \multicolumn{2}{|l|}{$\begin{array}{l}\text { CONTACTS: NAME/TITLE/PHONE } \\
\text { Thomas G. Gsel1 } \\
\text { Sales Engineer (503) 228-8691 }\end{array}$} \\
\hline \multicolumn{3}{|c|}{$\begin{array}{l}\text { FORMER FIRM NAAME, IF ANY, AND YEAR ESTABLISHED } \\
\text { None }\end{array}$} \\
\hline \multicolumn{3}{|c|}{ Zidell Explorations, Inc. Same Address } \\
\hline $\begin{array}{l}\text { VALVE PLANT LOCATIONS } \\
3500 \text { S.E. 22nd Avenue } \\
\text { Portland, OR } 97202\end{array}$ & \begin{tabular}{|r|r} 
BER OF EMPLOYEES & PIAN \\
bout 480 & $9678 \mathrm{~S}$ \\
\end{tabular} & $\begin{array}{l}\text { FOOR SPACE } \\
\text { Ft. Shop } \\
\text { Ft. Warehouse }\end{array}$ \\
\hline \multicolumn{3}{|c|}{$\begin{array}{l}\text { BRIEF STATEMENT AS TO STANDARD VALVE PRODUCTS } \\
\text { Our basic product line is carbon steel, special alloy, stainless steel, and forged } \\
\text { steel wedge gates, globes and checks. We carry a stock from } 1 / 4 \text { " in size through } \\
42 " \text {, and from } 150 \# \text { through } 1500 \# \text {. We also carry a limited stock of stainless steel } \\
\text { and carbon steel ball valves. }\end{array}$} \\
\hline \multicolumn{3}{|c|}{$\begin{array}{l}\text { BRIEF STATEMENT AS TO DEVELOPMENTAL AND TESTIIG CAPABILITIES } \\
\text { We have the ability and facilities to test any of the above mentioned. }\end{array}$} \\
\hline \multicolumn{3}{|c|}{$\begin{array}{l}\text { REMARKS: COMMENTS OF FUTURE PRODUCT LINES THAT MAY BE AVAILABLE BY 1982?, BY } 1987 \text { ? } \\
\text { Good possibilities of having a wider variety of stock to include high pressure } \\
\text { ball valves, knife gates and butterfly valves. As to when, it is impossible } \\
\text { to say. We do have contacts overseas to purchase these items now, but do not } \\
\text { stock them at present. }\end{array}$} \\
\hline \multicolumn{3}{|c|}{$\begin{array}{l}\text { * LIS'I NAME AND ADDRESS AS YOU WOULD LIKE TO HAVE LISTED IN THE FINAL REPORT } \\
\text { Zidel1 Explorations, Inc. } \\
3121 \text { S. W. Moody Avenue } \\
\text { Portland, Oregon } 97201\end{array}$} \\
\hline
\end{tabular}


Appendix B

CAPABILITY RESPONSES OF VALVE-ACTUATOR MANUFACTURERS 
Appendix B

CAPABILITY RESPONSES OF VALVE-ACTUATOR MANUFACTURERS

$\underline{\text { Page }}$

Anchor/Darling Valve Co. . . . . . . . . . . . . . 123

Andco Actuator Products, Inc. . . . . . . . . . . . . 124

Arral Industries, Inc. . . . . . . . . . . . . . 125

Automated Valve \& Control . . . . . . . . . . . . . 126

Becker Precision Equipment, Inc. . . . . . . . . . . . . 127

Bellows International, Division of IBEC Industries, Inc. . . . . 128

Beswick Engineering . . . . . . . . . . . . . . . 129

Bettis Corporation . . . . . . . . . . . . . . 130

EIM Company, Inc. . . . . . . . . . . . . . . . . . 131

Limitorque Corporation . . . . . . . . . . . . . . 132

Newbrook Machine Corp. . . . . . . . . . . . . . 133

PARKER-HANNIFIN CORPORATION . . . . . . . . . . . . 134

RKL Controls, Inc. . . . . . . . . . . . . . . 135

RACO INTERNATIONAL, INC. . . . . . . . . . . . . . 136

Raymond Control Systems . . . . . . . . . . . . . 137

Roto Hammer Company, Inc. . . . . . . . . . . . . 138

Rotork Controls, Inc. . . . . . . . . . . . . . . 139

Sulzer Bros., Inc. . . . . . . . . . . . . . . . . 140 


\begin{tabular}{|c|c|c|c|}
\hline \multirow{2}{*}{\multicolumn{2}{|c|}{$\begin{array}{l}\text { FIRM NAME/ADDRESS/PHONE* } \\
\text { Anchor/Darling Valve Co. } \\
\text { I Belmont Avenue, Suite } 320 \\
\text { Bala Cynwyd, PA } 19004\end{array}$}} & $\begin{array}{l}\text { YEAR PRESENT FIRM ESTABLISHED } \\
1968\end{array}$ & $\begin{array}{l}\text { SURVEY DATE } \\
6 / 20 / 77\end{array}$ \\
\hline & & \multicolumn{2}{|c|}{$\begin{array}{l}\text { CONTACTS: NAME/TITLE/PHONE } \\
\text { R. E. Bergman, Proposal Mgr. (215)667-9090 } \\
\text { R. E. Rhinehart, Mgr. Marketing Operations }\end{array}$} \\
\hline \multicolumn{4}{|c|}{$\begin{array}{l}\text { FORMER FIRM NAME, IF ANY, AND YEAR ESTABLISHED } \\
\text { Darling Valve \& Manufacturing Co. } 1888 \\
\text { Anchor Valve Co. } 1946\end{array}$} \\
\hline \multicolumn{4}{|c|}{$\begin{array}{l}\text { PARENT COMPANY } \\
\text { Anchor/Darling Industries } \\
\text { One. Belmont Avenue, Suite 406, Bala Cynwyd, PA } 19004\end{array}$} \\
\hline \multicolumn{2}{|c|}{ PLANT LOCATIONS } & \multicolumn{2}{|c|}{ PLANT FLOOR SPACE } \\
\hline \multicolumn{4}{|c|}{$\begin{array}{l}\text { BRIEF STATEMENT AS TO ACTUATOR PRODUCTS } \\
\text { All actuators are custom engineered for a specific application. The basic design } \\
\text { is a hydraulic unit for use on translating stem valves that incorporates a stored } \\
\text { energy source to assure operation in the event of power failure. The majority } \\
\text { of actuators supplied to date have been used on main steam isolation valves for } \\
\text { light water nuclear plants. }\end{array}$} \\
\hline \multicolumn{4}{|c|}{$\begin{array}{l}\text { BRIEF STATEMENT AS TO DEVELOPMENTAL AND TESTING CAPABILITIES } \\
\text { Our custom engineering approach allows Anchor/Darling to offer actuators for } \\
\text { our complete range of gate and globe valves, for all the operating conditions } \\
\text { you have listed. }\end{array}$} \\
\hline \multicolumn{4}{|c|}{ REMARKS: COMMENTS OF FUTURE PRODUCT LINES THAT MAY BE AVAILABLE BY 1982? BY 1987? } \\
\hline
\end{tabular}

* LIST NAME AND ADORESS $\Lambda S$ YOU WOULD LIKE TO HAVE IT LISTED IN THE REPORT 


\begin{tabular}{|c|c|c|}
\hline \multirow{2}{*}{$\begin{array}{l}\text { FIRM NAME/ADDRESS/PHONE } \\
\text { Andco Actuator Products, Inc. } \\
\text { P. 0. Box } 988 \\
\text { Buffalo, New York } 14240 \\
\text { (716) } 681-7400\end{array}$} & $\begin{array}{c}\text { YEAR PRESENT FIRM ESTABLISHED } \\
1977\end{array}$ & $\begin{array}{l}\text { SURVEY DATE } \\
8-9-77\end{array}$ \\
\hline & \multicolumn{2}{|c|}{$\begin{array}{l}\text { CONTACTS: NAME/TITLE/PHONE } \\
\text { Douglas D. Schumann/Vice President } \\
\text { (716) } 681-7400\end{array}$} \\
\hline \multicolumn{3}{|c|}{$\begin{array}{l}\text { FORMER FIRM NAME, IF ANY, AND YEAR ESTABLISHED } \\
\text { Andco Incorporated - } 1907\end{array}$} \\
\hline \multicolumn{2}{|l|}{ PARENT COMPANY } & \\
\hline $\begin{array}{l}\text { VALVE PLANT LOCATIONS } \\
\text { Buffaio, NY }\end{array}$ & \begin{tabular}{l|r} 
BER OF EMPLOYEES & PLAN \\
105 & 1
\end{tabular} & FOLOR SPACE \\
\hline \multicolumn{3}{|c|}{$\begin{array}{l}\text { The Andco Actuator is an electro-mechanical device to provide } 1 \text { nedr Purce in the } \\
\text { range of } 50 \text { to } 10,000 \text { pounds and motion up to } 60 \text { inches. It uses a standard } \\
\text { electric motor, conventional drive screw and a patented thrust overload protection } \\
\text { device. It can be equipped with various position control options. It requires } \\
\text { only electric power for operation. }\end{array}$} \\
\hline \multicolumn{3}{|c|}{$\begin{array}{l}\text { NOTE: Andco Metal Industry Products in conjunction with Andco Technical Services, } \\
\text { Ind., has provide specially designed high temperature valves and is } \\
\text { capable of designing and producing valves of the type required for coal } \\
\text { conversion. }\end{array}$} \\
\hline \multicolumn{3}{|c|}{$\begin{array}{l}\text { BRIEF STATEMENT AS TO DEVELOPMENTAL AND TESTING CAPABILITIES } \\
\text { Testing facilities currently exist for both production usage and ongoing product } \\
\text { development. The personnel possess the knowledge and experience to construct } \\
\text { additional testing facilities for any special requirements which may develop } \\
\text { from an inquiry such as the Oak Ridge National Laboratory letter of July } 15,1977 .\end{array}$} \\
\hline
\end{tabular}

REMARKS: COMMENTS OF FUTURE PRODUCT LINES THAT MAY BE AVAIIABLE BY 1982?, BY 1987? Improvements, modifications and extensions of the actuator's capabilities are an ongoing process. A rotary actuator incorporating the same design and integral overload device is under development at this time.

* IIST NAME AND ADDRESS A3 YOU WOULD LIKE TO HAVE LISTED IN THE FINAL REPORT, 


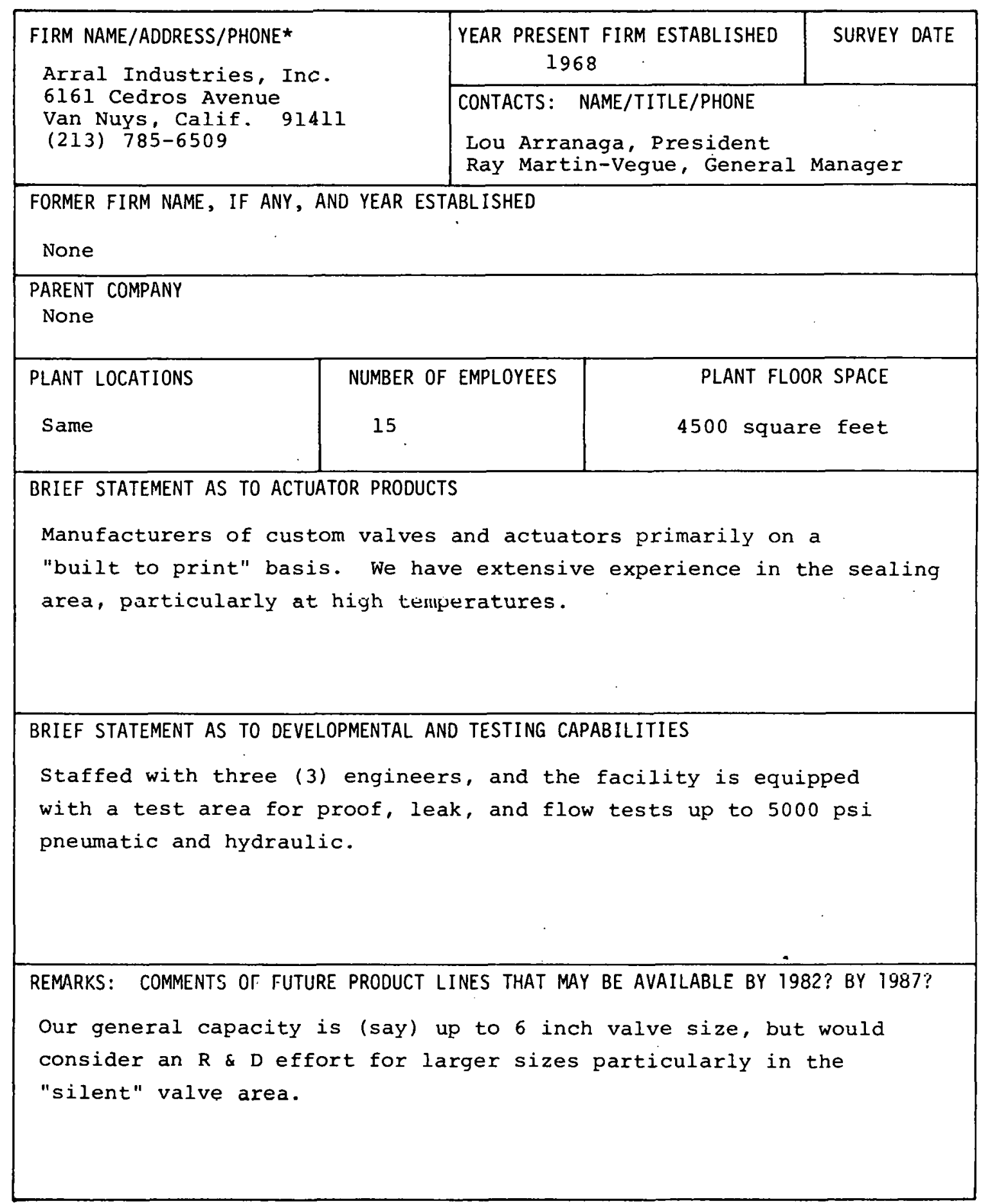

* LIST NAME AND ADDRESS AS YOU WOULD LIKE TU HAVE II LISIEU IN THE REPORT 


\begin{tabular}{|c|c|c|c|}
\hline \multirow{2}{*}{$\begin{array}{l}\text { FIRM NAME/ADDRESS/PHONE* } \\
\text { Automated Valve \& Control } \\
\text { P. 0. BOx } 26724 \\
\text { Houston, TX } 77207 \\
\text { (713) 644-1888 }\end{array}$} & \multicolumn{2}{|c|}{$\begin{array}{l}\text { YEAR PRESENT FIRM ESTABLISHED } \\
1972\end{array}$} & $\begin{array}{l}\text { SURVEY DATE } \\
0-3-77\end{array}$ \\
\hline & \multicolumn{3}{|c|}{ CONTACTS: NAME/TITLE/PHONE } \\
\hline \multicolumn{4}{|c|}{ FORMER FIRM NAME, IF ANY, AND YEAR ESTABLISHED } \\
\hline \multicolumn{4}{|l|}{$\begin{array}{l}\text { PARENT COMPANY } \\
\text { Paltex Corporation }\end{array}$} \\
\hline $\begin{array}{l}\text { PLANT LOCATIONS } \\
5939 \text { Nunn Street } \\
\text { Houston, TX } 77087\end{array}$ & $\begin{array}{c}\text { NUMBER OFं EMPLOYEES } \\
7\end{array}$ & \multicolumn{2}{|c|}{$\begin{array}{l}\text { PLANT FLOOR SPACE } \\
6000^{\prime}\end{array}$} \\
\hline \multirow{2}{*}{\multicolumn{4}{|c|}{$\begin{array}{l}\text { BRIEF STATEMENT AS TO ACTUATOR PRODUCTS } \\
\text { Sales \& Service: Raymond Control Systems Pneumatic \& Electric Actuators } \\
\text { Bettis Corp. Pneumatic Actuators } \\
\text { Design \& Fabrication of Gate \& Globe Valve Actuator Adaptions, \& Qtr. Turn Valves } \\
\text { Repair and Reconditioning all types Electric Actuators. } \\
\text { Field Service Technicians } \\
\text { New Installations of Pneumatic, Electric, and Manual Gear Operators }\end{array}$}} \\
\hline & & & \\
\hline \multicolumn{4}{|c|}{ BRIEF STATEMENT AS TO DEVELOPMENTAL AND TESTING CAPABILITIES } \\
\hline \multicolumn{4}{|c|}{ REMARKS: COMMENTS OF FUTURË PRODUCT LINES THAT MAY BE AVAILABLE BY 1982? BY 1987? } \\
\hline
\end{tabular}

* LIST NAME AND ADDRESS AS YOU WOULd LIKE TO HAVE IT LISTED IN THE REPORT 


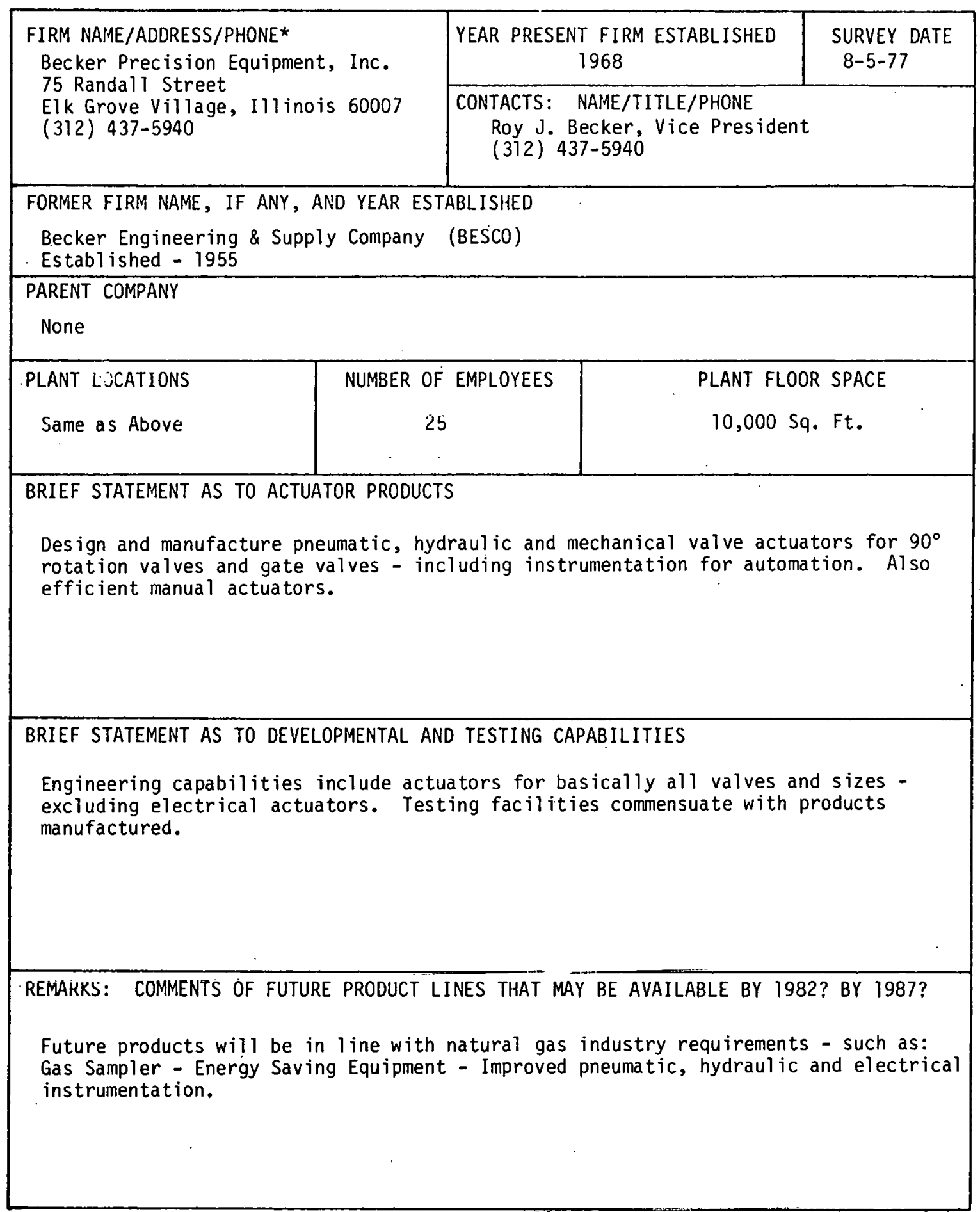

* LIST NAME AND ADDRESS AS YOU WOULD LIKE TO HAVE IT LISTED IN THE REPORT 


\begin{tabular}{|c|c|c|}
\hline \multirow{2}{*}{$\begin{array}{l}\text { FIRM NAME/ADDRESS/PHONE* } \\
\text { Bellows Intermld Liuldal } \\
\text { Division of IBEC Industries, Inc. } \\
200 \text { West Exchange Street } \\
\text { Akron, Ohio } 44309 \\
\text { (216) } 762-0471\end{array}$} & $\begin{array}{c}\text { YEAR PRESENT FIRM ESTABLISHED } \\
1957\end{array}$ & $\begin{array}{c}\text { SURVEY DATE } \\
7-? .9-77\end{array}$ \\
\hline & \multicolumn{2}{|c|}{$\begin{array}{l}\text { CONTACTS: NAME/TITLE/PHONE } \\
\text { Chas. W. Ward } \\
\text { Vice President, Product Development } \\
\text { (216) } 762-047 \text {. Ext. } 318 \\
\end{array}$} \\
\hline \multicolumn{3}{|c|}{ FORMER FIRM NAME, IF ANY, AND YEAR ESTABLISHED } \\
\hline \multicolumn{3}{|c|}{$\begin{array}{l}\text { PARENT COMPANY } \\
\text { International Basic Economy Corporation } \\
1271 \text { Avenue of the Americas, New York, New York } 10020\end{array}$} \\
\hline \begin{tabular}{l|l} 
PLANT LOCATIONS & NUMBER \\
Ohio & \\
Pennsylvania &
\end{tabular} & \multicolumn{2}{|c|}{$\begin{array}{l}\text { PLANT FLOOR SPACE } \\
150,000 \mathrm{Sq} . \mathrm{Ft} \text {. }\end{array}$} \\
\hline \multicolumn{3}{|c|}{$\begin{array}{l}\text { BRIEF STATEMENT AS TO ACTUATOR PROOUCT'S } \\
\text { Rotary and Linear actuators } \\
\text { Hydraul ic Power units and controls }\end{array}$} \\
\hline \multicolumn{3}{|c|}{$\begin{array}{l}\text { BRIEF STATEMENT AS TO DEVELOPMENTAL AND TESTING CAPABILITIES } \\
\text { Can handle custom requirements or can develop standard line to suit valves as } \\
\text { the valve requirements become identified. Thirty-five development engineers. }\end{array}$} \\
\hline \multicolumn{3}{|c|}{$\begin{array}{l}\text { REMARKS: COMMENTS OF FUTURE PRODUCT LINES THAT MAY BE AVAILABLE BY 1982? BY } 1987 \text { ? } \\
\text { Linear actuators to } 250,000 \mathrm{lb} \text {. force. } \\
\text { Rotary actuators to } 125,000 \mathrm{lb} \text {. ft. torque. } \\
\text { Controls to match. }\end{array}$} \\
\hline
\end{tabular}

* LIST NAME AND ADDRESS AS YOU WOULD LIKE TO HAVE IT LISTED IN THE REPORT 


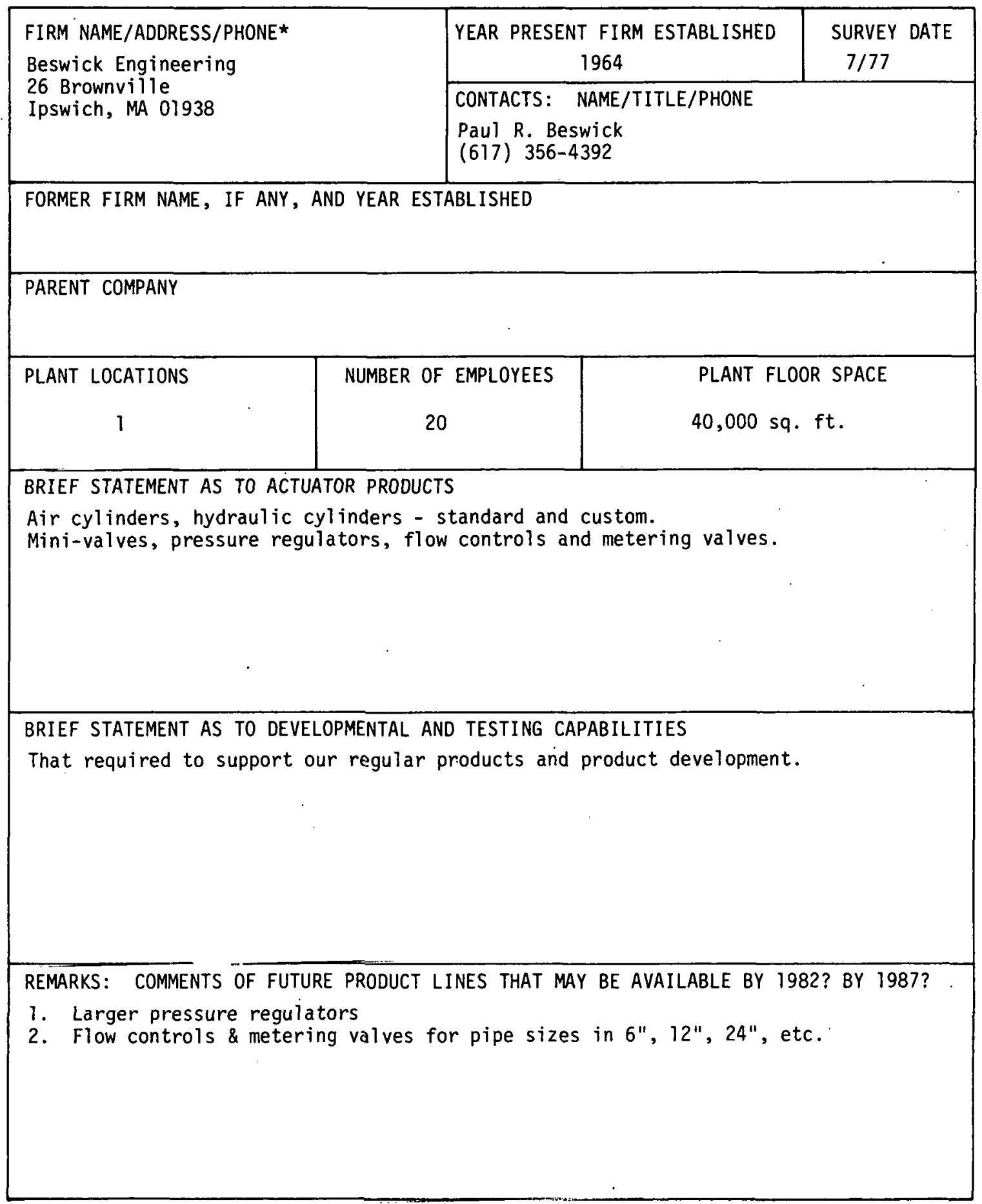

* LIST NAME AND ADDRESS AS YOU WOULD LIKE TO HAVE IT LISTED IN THE REPORT 


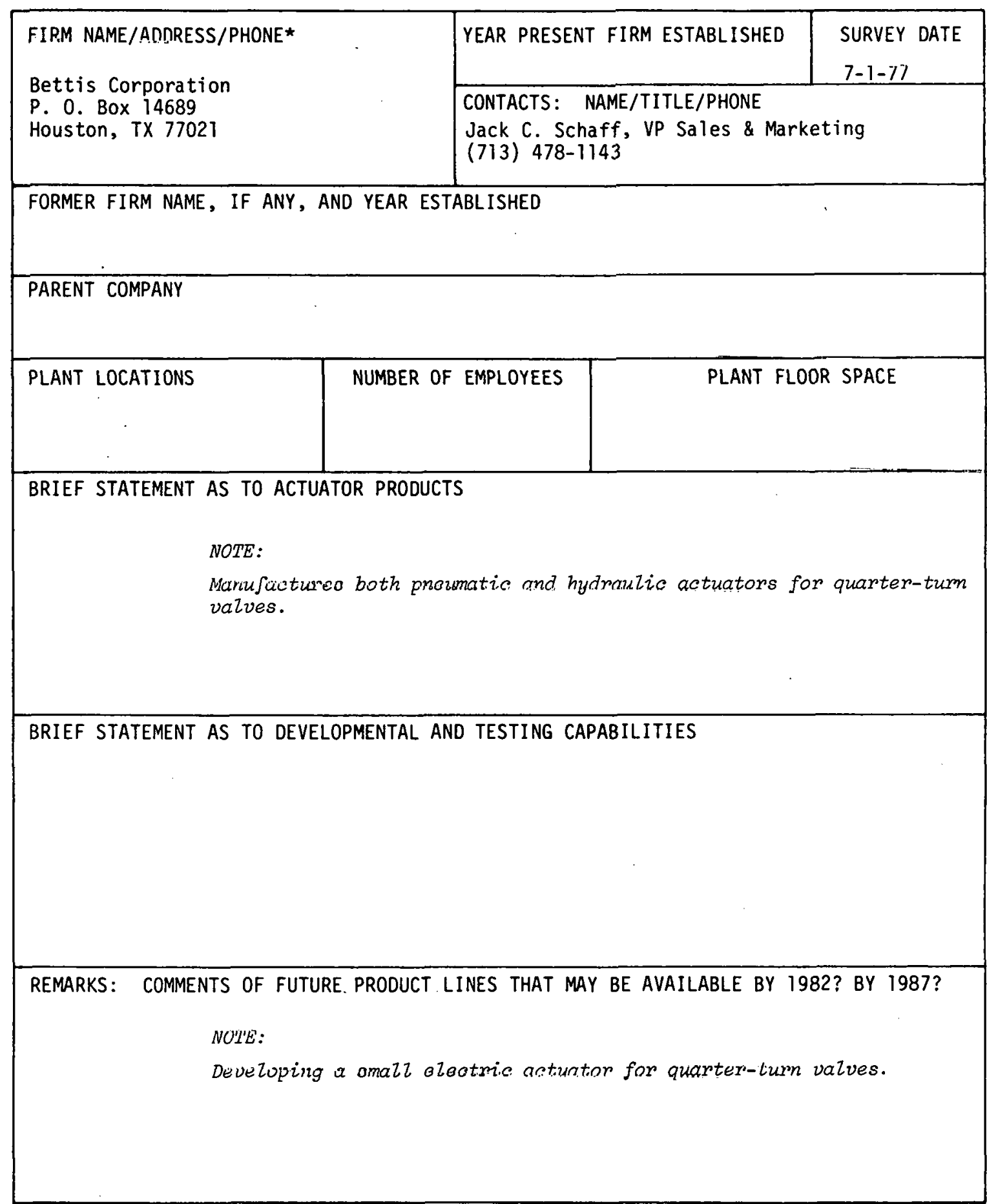

* LIST NAME AND ADDRESS AS YOU WOULD LIKE TO HAVE IT. LISTED IN THE REPORT 


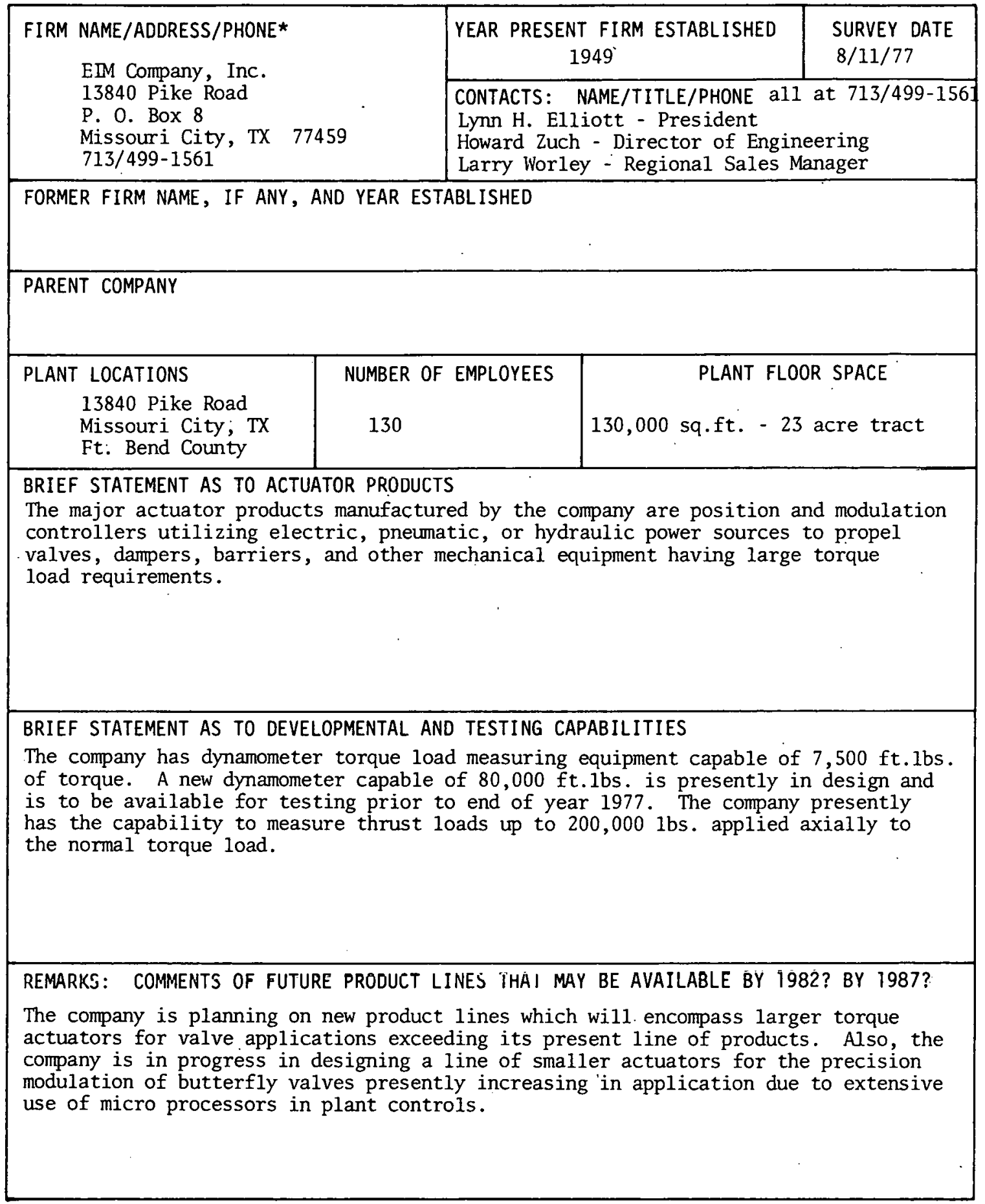

* LIST NAME AND ADDRESS AS YOU WOULD LIKE TO HAVE IT LISTED IN THE REPORT 


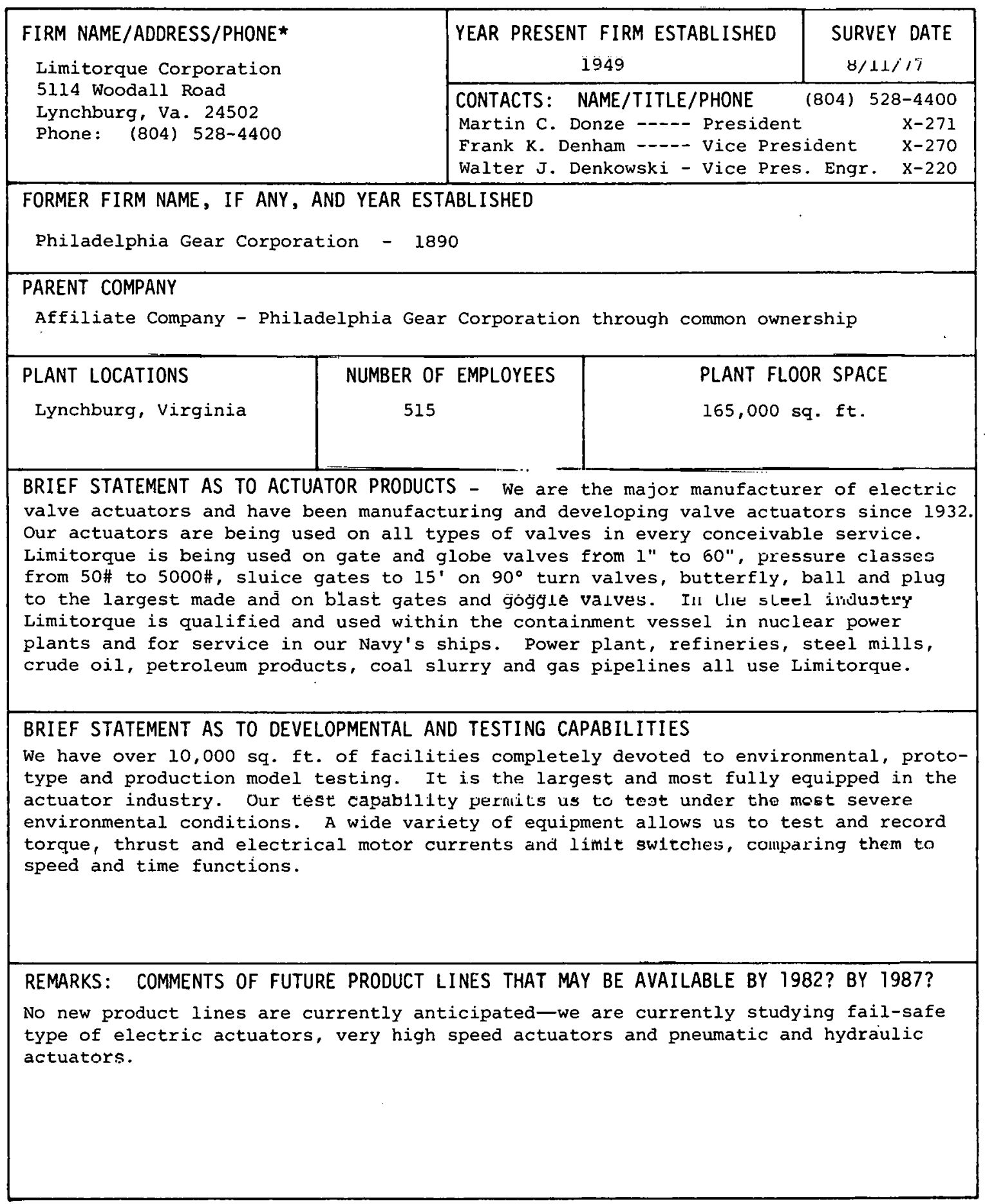

* LIST NAME AND ADDRESS AS YOU WOULD LIKE TO HAVE IT LISTED IN THE REPORT 


\begin{tabular}{|c|c|c|c|c|}
\hline \multirow{2}{*}{\multicolumn{2}{|c|}{$\begin{array}{l}\text { FIRM NAME/ADDRESS/PHONE* } \\
\text { Newbrook Machine Corp. } \\
16 \text { Mechanic St. } \\
\text { Silver Creek, New York } 14136\end{array}$}} & \multicolumn{2}{|c|}{$\begin{array}{l}\text { YEAR PRESENT FIRM ESTABLISHED } \\
1952\end{array}$} & SURVEY DATE \\
\hline & & \multicolumn{3}{|c|}{$\begin{array}{l}\text { CONTACTS: NAME/TITLE/PHONE } \\
\text { R. Newman, Gen1 Mgr. } \\
\text { 7i6-934-2644 }\end{array}$} \\
\hline \multicolumn{5}{|c|}{$\begin{array}{l}\text { FORMER FIRM NAME, IF ANY, AND YEAR ESTABLISHED } \\
\text { N/A }\end{array}$} \\
\hline \multicolumn{5}{|c|}{$\begin{array}{ll}\text { PARENT COMPANY } & \text { N/A }\end{array}$} \\
\hline $\begin{array}{l}\text { PLANT LOCATIONS } \\
\text { See Address Above }\end{array}$ & $\begin{array}{r}\text { NUMBER } \\
106\end{array}$ & EMPLOYEES & $\begin{array}{r}\text { PLANT FL } \\
150,000 \mathrm{sq} .\end{array}$ & SPACE \\
\hline \multicolumn{5}{|c|}{$\begin{array}{l}\text { BRIEF STATEMENT AS TO ACTUATOR PRODUCTS } \\
\text { We build special units for all applications. Our major emphasis is } \\
\text { currently on development and pilnt production projects. }\end{array}$} \\
\hline \multicolumn{5}{|c|}{$\begin{array}{l}\text { BRIEF STATEMENT AS TO DEVELOPMENTAL AND TESTING CAPABILITIES } \\
\text { Newbrook is primarily an } R \text { \& } D \text { operation. We do specialized } \\
\text { fabrication, machining, assembly and testing (functional, NDT, } \\
\text { Hydrotesting, helium leam testing, physical testing, } \\
\text { Metallurgical testing etc.) }\end{array}$} \\
\hline \multicolumn{5}{|c|}{$\begin{array}{l}\text { REMARKS: CUMMENTS OF FUTURE PRODUCT LINES THAT MAY BE AVAILABLE BY 1982? BY 1987? } \\
\text { We have committed ourselves to the development of energy new sources. } \\
\text { We have been involved in the Nuclear field for } 25 \text { years. We are } \\
\text { currently working hydrogen fusion with the Univ. of Rochester. } \\
\text { We are making fuel cell components for United Technology and the } \\
\text { Navy. We recently built experimental wind mill components. }\end{array}$} \\
\hline
\end{tabular}

* LISI NAME AND ADDRESS AS YOU WOULD LIKE TO HAVE IT LISTED IN THE REPORT 


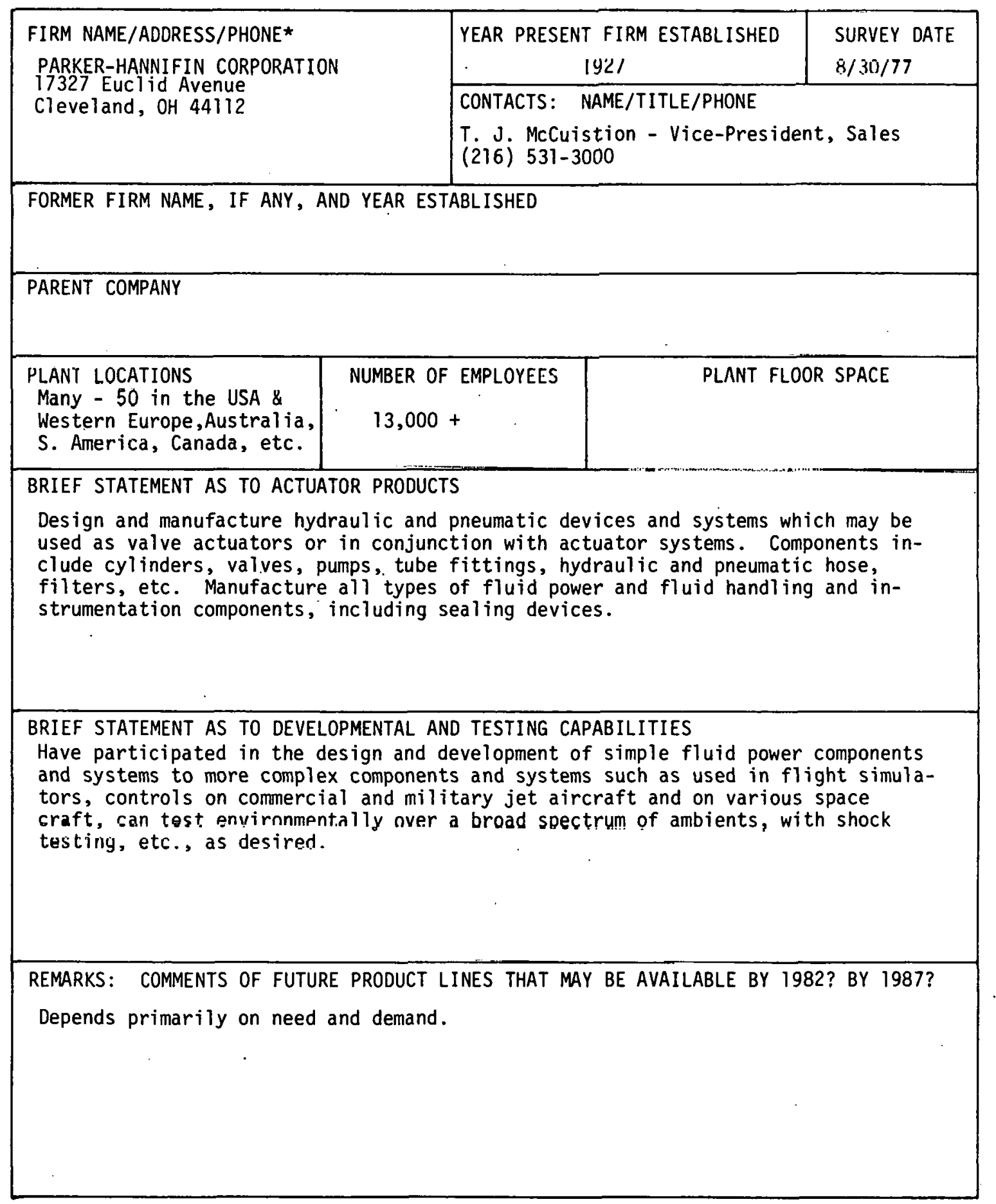

* LIST NAME AND ADDRESS AS yOU WOULD LIKE TO HAVE IT LISTED IN THE REPORT 


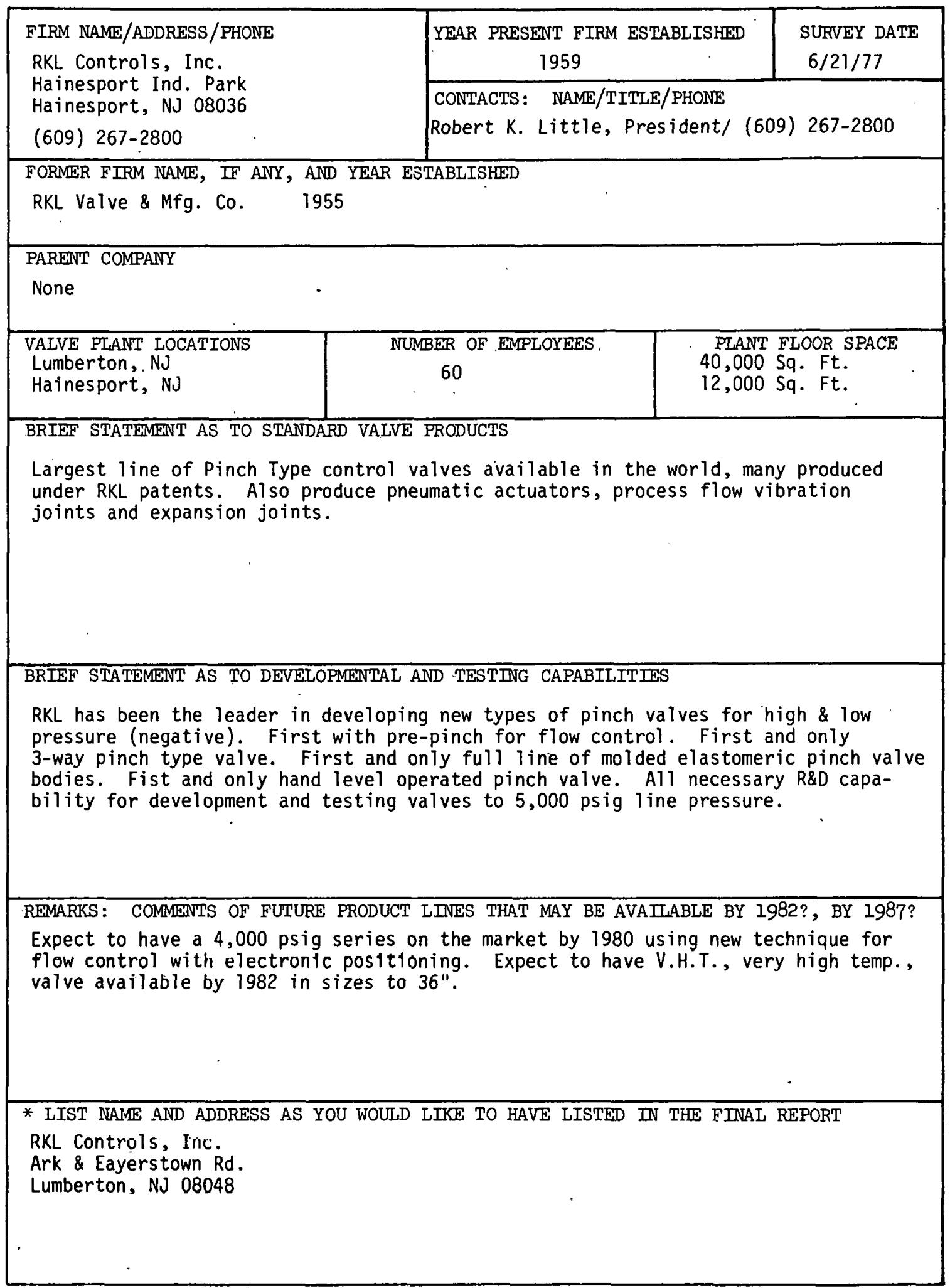




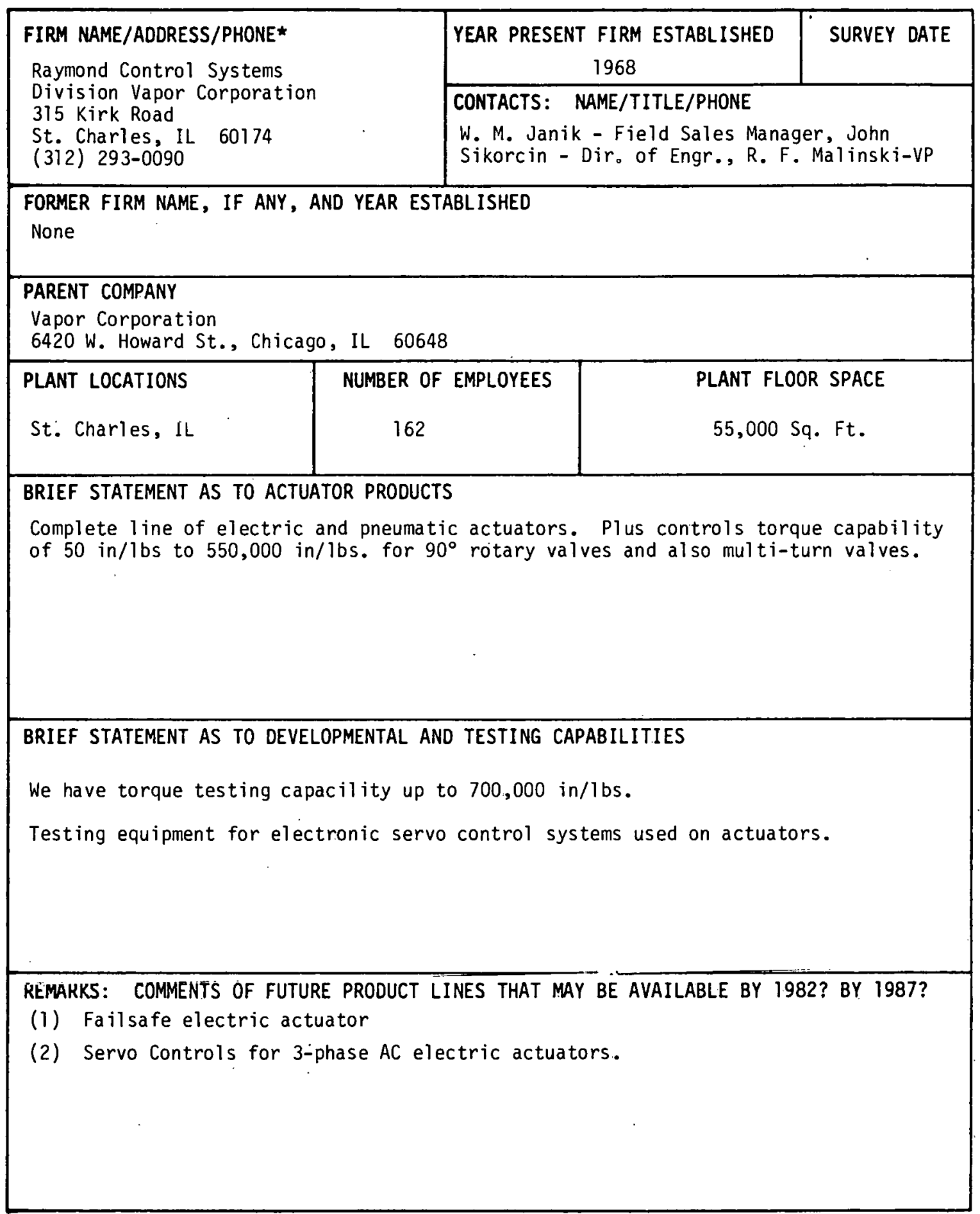

* LIST NAME AND ADDRESS AS YOU WOULD LIKE TO HAVE IT LISTED IN THE REPORT 


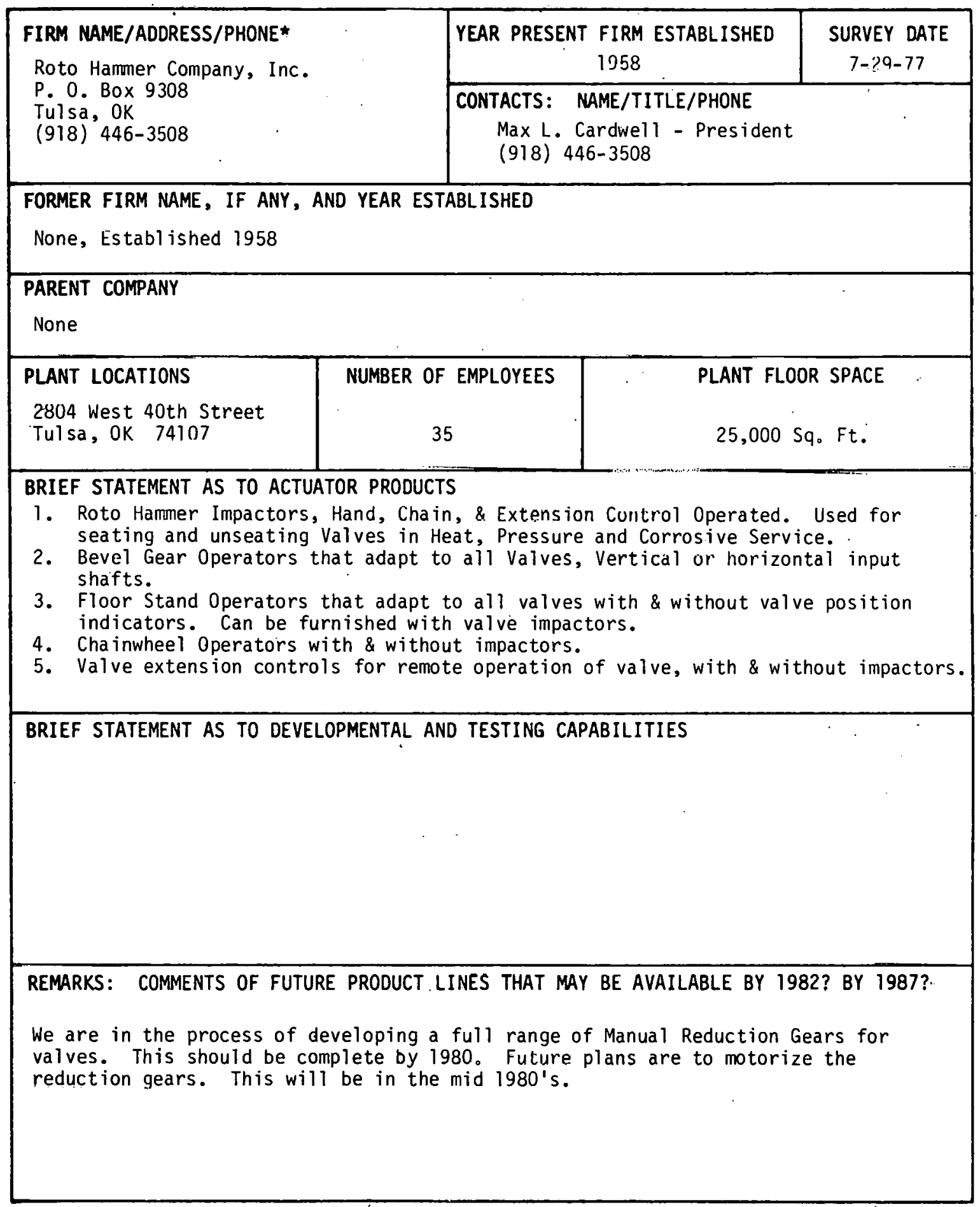

* List name and adoress as you wOULd LIKe to have IT LISTED IN the RePort 


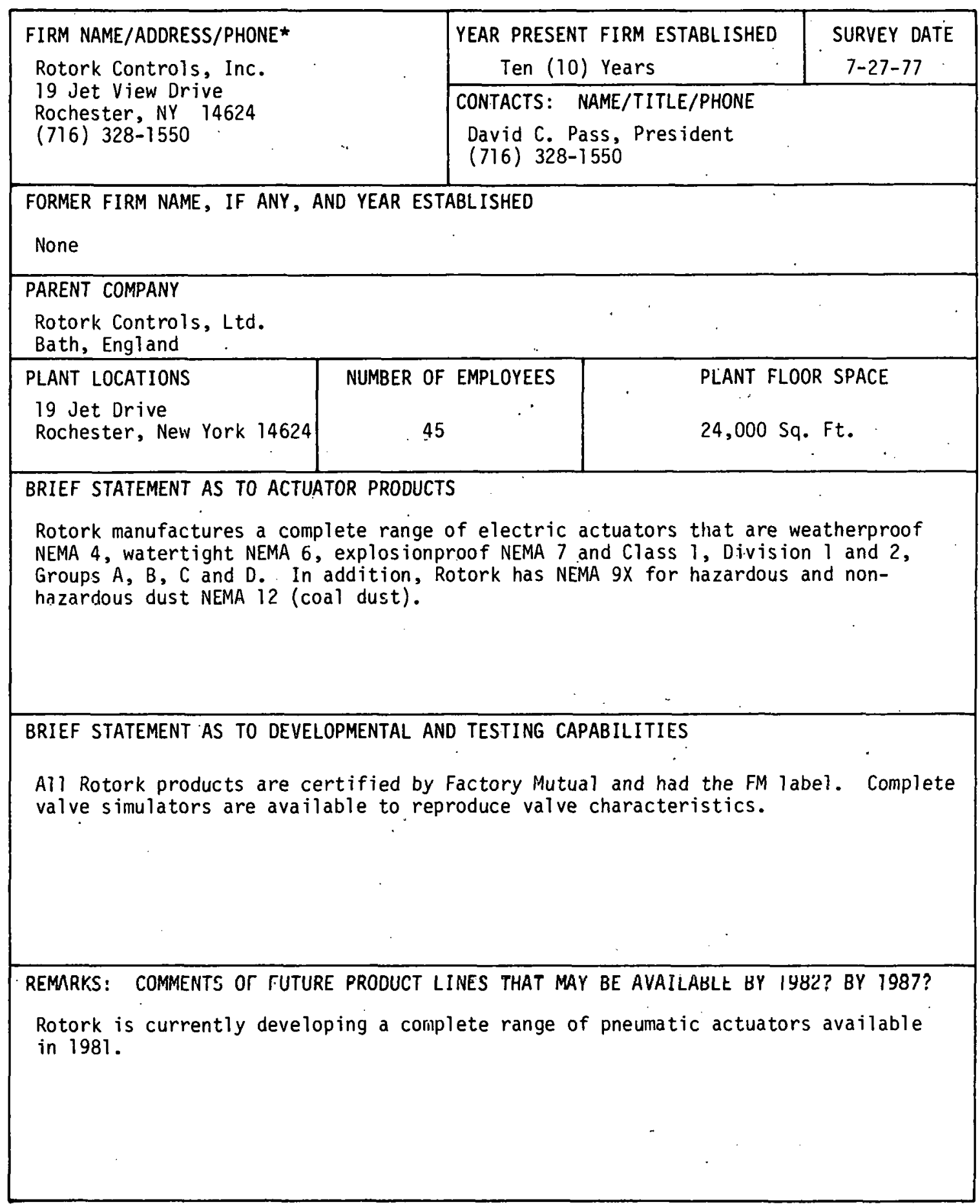

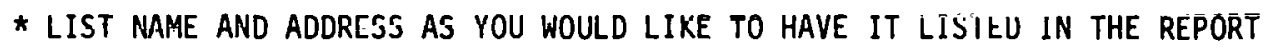




\begin{tabular}{|c|c|c|}
\hline \multirow{2}{*}{$\begin{array}{l}\text { FIRM NAME/ADDRESS/PHONE } \\
\text { Sulzer Bros., InC. } \\
19 \text { Rector Street } \\
\text { New York, New York } 10006 \\
(212) 425-4560\end{array}$} & $\begin{array}{l}\text { YEAR PRESENT FIRM ESTABLISHED } \\
1940 \text { (New York Office) }\end{array}$ & $\begin{array}{l}\text { SURVEY DATE } \\
7 / 19 / 77\end{array}$ \\
\hline & \multicolumn{2}{|c|}{$\begin{array}{l}\text { CONTACTS: NAME/TITLE/PHONE } \\
\text { Walter P. Gadient, Manager } \\
\text { Power Plant Components Division }\end{array}$} \\
\hline \multicolumn{3}{|c|}{ FORMER FIRM IAAME, IF ANY, AND YEAR ESTABLISHED } \\
\hline \multicolumn{3}{|c|}{$\begin{array}{l}\text { PARENT COMPANY } \\
\text { Founded } 1834 \text { Sulzer Brothers Limited, } \mathrm{CH}-8401 \text {, } \\
\text { Winterthur, Switzerland }\end{array}$} \\
\hline $\begin{array}{l}\text { VALVE PLANT LOCATIONS } \\
\text { Winterthur, Switzerland }\end{array}$ & \begin{tabular}{l|r} 
BER OF EMPLOYEES & PLAI \\
5,511 total & 3,90 \\
\end{tabular} & $\begin{array}{l}\text { FLOOR BPACE } \\
00 \text { sq. ft. }\end{array}$ \\
\hline \multicolumn{3}{|c|}{$\begin{array}{l}\text { BRIEF STATEMENT AS TO STANDARD VALVE PRODUCTS } \\
\text { SuTzer standard valves, actuators and positioning controls are designed for high } \\
\text { pressure, high temperature applications with high requirements of flow control. } \\
\text { The given requirements, from a pressure and temperature polnt of view, are wcll } \\
\text { within our standard valve capabilities. The required sizes also can be considered } \\
\text { standard. The solids content of the medium is new; however, it appears to be } \\
\text { manageable. }\end{array}$} \\
\hline \multicolumn{3}{|c|}{$\begin{array}{l}\text { BRIEF STATEMENT AS TO DEVELOPMENTAI AND TESTING CAPABILITIES } \\
\text { Sulzer's activity in high pressure, high temperature valve applications required } \\
\text { from the beginning a high development and testing capability. Therefore, we feel } \\
\text { well qualified to satisfy these requirements. }\end{array}$} \\
\hline \multicolumn{3}{|c|}{$\begin{array}{l}\text { REMARKS: COMMENTS OF FUTURE PRODUCT LINES THAT MAY BE AVAIIABLE BY 1982?, BY 1987? } \\
\text { Large valves (valve matérials) for handl iny high tempcrature gases and requiring } \\
\text { fast closure and/or modulating exceeding the required data may be available in } \\
1982 \text {, as well as improved seat materials for still higher tightness and durability. }\end{array}$} \\
\hline \multicolumn{3}{|c|}{$\begin{array}{l}\text { * LIST NAME AND ADDRESS AS YOU WOULD LIKE TO HAVE LISTED IN THE FINAL REPOR' } \\
\text { Sulzer Bros., Inc. } \\
19 \text { Rector Street } \\
\text { New York, NY } 10006 \\
\quad \text { Walter P. Gadient }\end{array}$} \\
\hline
\end{tabular}


Append Ix C

SAMPLE LETTER OF INQUIRY TO BALL VALVE MANUFACTURERS 


\author{
OAK RIDGE National LabORAtORY \\ OPERATED BY \\ UNION CARBIDE CORPORATION \\ NUCLEAR DIVISION \\ CANBODE \\ POST OFFICE BOX X \\ OAK RIDGE, TENNESSEE 37830 \\ June 6,1977
}

\title{
Gentlemen:
}

The United States Energy Research and Development Administration/Fossil Energy, Major Facilities Project Management Division is conducting an investigation of the capability of industry to provide valves for coal conversion facilities of demonstration and commercial scale. This study is being performed at the Oak Ridge National Laboratory by Union Carbide Nuclear Division. Industry input is desired in two areas:

1. defining the present capability of industry to supply the required valves,

2. determining research and development needs, including lead time requirements for producing valves of advanced design.

An attachment including a capability questionnaire has been developed for the valve size and anticipated service applications. We hope that this will help provide the necessary information with a minimum of time and effort.

You are also invited to submit any additional ideas or suggestions which may help in making this investigation more beneficial to both governmental and industrial planners.

This is not a request for proposal; nor may it serve as a basis for any claim for reimbursement of costs for efforts expended. No remuneration will be provided; however, it is likely that this study will directly benefit the valve industry as well as the government and the public through normal government publication channels. Therefore, please do not supply any proprietary information.

We will appreciate your response to this questionnaire by July 15,1977 or earlier. If additional information or clarification is needed, please call me at (615) 483-8611, ext. 3-1416 or W. A. Bush at the same extension.

Your help in this effort will be appreciated.

Very truly yours,

Edward C. Slade

UCC-ND Engineering

ECS : cr

At trachment 
Attachment

Page 1 of 3

\section{BACKGROUND}

Assuming that coal conversion wlll become a major industry within the next ten to fifteen years: thls investigation Is attempting to assess the capabillty of, and to ascertaln the impact that would be imposed upon the valve Industry. At present, It appears that the coal conversion processes operate in the range of the present petrochemical Industry, except at the portion of the process where the coal is converted to gas, oll, and slag/char.

\section{INVESTIGATION AND REPORT}

As a part of this survey, we would like to obtain two sets of catalogs on your product I Ine as would be applicable to the coal conversion industry. Your cooperation in fllling out the attached sheets will provide general information about your company and its products and an indlcation of which of your products fit within the unlque requi rements of the coal conversion prooeccoc. Thic licting of valvo applloatione wac oompllod from proliminary conceptual designs of planned demonstration and commerclal size and coal conversion processes. Only those applications which appear to be the most stringent are llsted. 
SPECIAL VALVE REQUIREMENTS

THE FOLLONING VALVE SIZES AND PROCESS REQUIREMERTS APPEAR TO REPRESENT THE MOST

APPLICATIONS A "BALL TYPE" MAY BE UTILIZED. THE VALVE SHOULD BE CAPABLE OF

OPERATING AGA ANST A FULL PRESSURE DIFFERENTIAL, SHOULD REPAIIN COMMARERIALLY LEAK-

\begin{tabular}{|c|c|c|c|c|c|c|c|}
\hline \multicolumn{8}{|l|}{ PROCESS CONDITIONS } \\
\hline A & & B & c & 0 & 1 & 2 & 3 \\
\hline FLOH STREAM COMPOSITION & & $\begin{array}{l}\text { MOMIINAL } \\
\text { SIZE }\end{array}$ & PRESSURE & $\begin{array}{l}\text { TEEMPER- } \\
\text { ATURE. }\end{array}$ & $\begin{array}{l}\text { AVAILABLE } \\
\text { SIZES }\end{array}$ & $\begin{array}{l}\text { VALVEE } \\
\text { TYPES }\end{array}$ & $\begin{array}{l}\text { RECOPMEENDED } \\
\text { MATERIALS }\end{array}$ \\
\hline & & INCHES & $\begin{array}{ll}\text { P.S.I.G. } \\
\end{array}$ & ${ }^{\circ} \mathrm{F}$ & & & $\begin{array}{l}\text { BODY,BALL, } \\
\text { IRIM ETC. }\end{array}$ \\
\hline 50\% COAL (SIZE DISTRIBUTION "A")/50\% GAS & vi & $6,12,24$ & 600 & 660 & & & \\
\hline 50\% COAL (SIZE DISTRIBUTION "A")/50\% GAS & v2 & $6,12,24$ & 1000 & 660 & & & \\
\hline 50\% COAL (SIZE DISTRIBUTION "A")/50\% GAS & v3 & $6,12,24$ & 1600 & 660 & & & \\
\hline 50\% COAL (SIZE DISTRIBUTION "B")/50\% :ATER & v4 & $6,12,24$ & 1250 & 660 & & & \\
\hline 50\% COAL (SIZE DISTRIBUTION "B")/50\% HATER & $2 v^{2}$ & $6,12,24$ & 1600 & 660 & & & \\
\hline 50\% COAL (SIZE UISTKIBUTIION "B")/50\% HATER & $\sqrt{6}$ & $6,12,24$ & 4300 & 625 & & & \\
\hline 50\% COAL (SIZE DISTRIBUTION "B")/50\% OIL & $\mathrm{v7}$ & $6,10,12$ & $i 250$ & 700 & & & \\
\hline $50 \%$ SLAG/50\% GAS & v8 & $6,10,12$ & 1250 & 700 & & & \\
\hline 50X SLAG/50\%, GAS & 19 & 6 & 1250 & 1200 & & & \\
\hline 50\% CHAR/50\% GAS & w10 & $6,10,12$ & 1150 & 600 & & & \\
\hline $100 \%$ CAS & vil & 12,24 & 1250 & 700 & & & \\
\hline $100 \%$ WATER & $\mathrm{V} 12$ & $6,10,12$ & 1250 & 600 & & & \\
\hline $100 \%$ OXYGEN & V13 & 8 & 1300 & 300 & & & \\
\hline
\end{tabular}

RESPONSE MATRIX

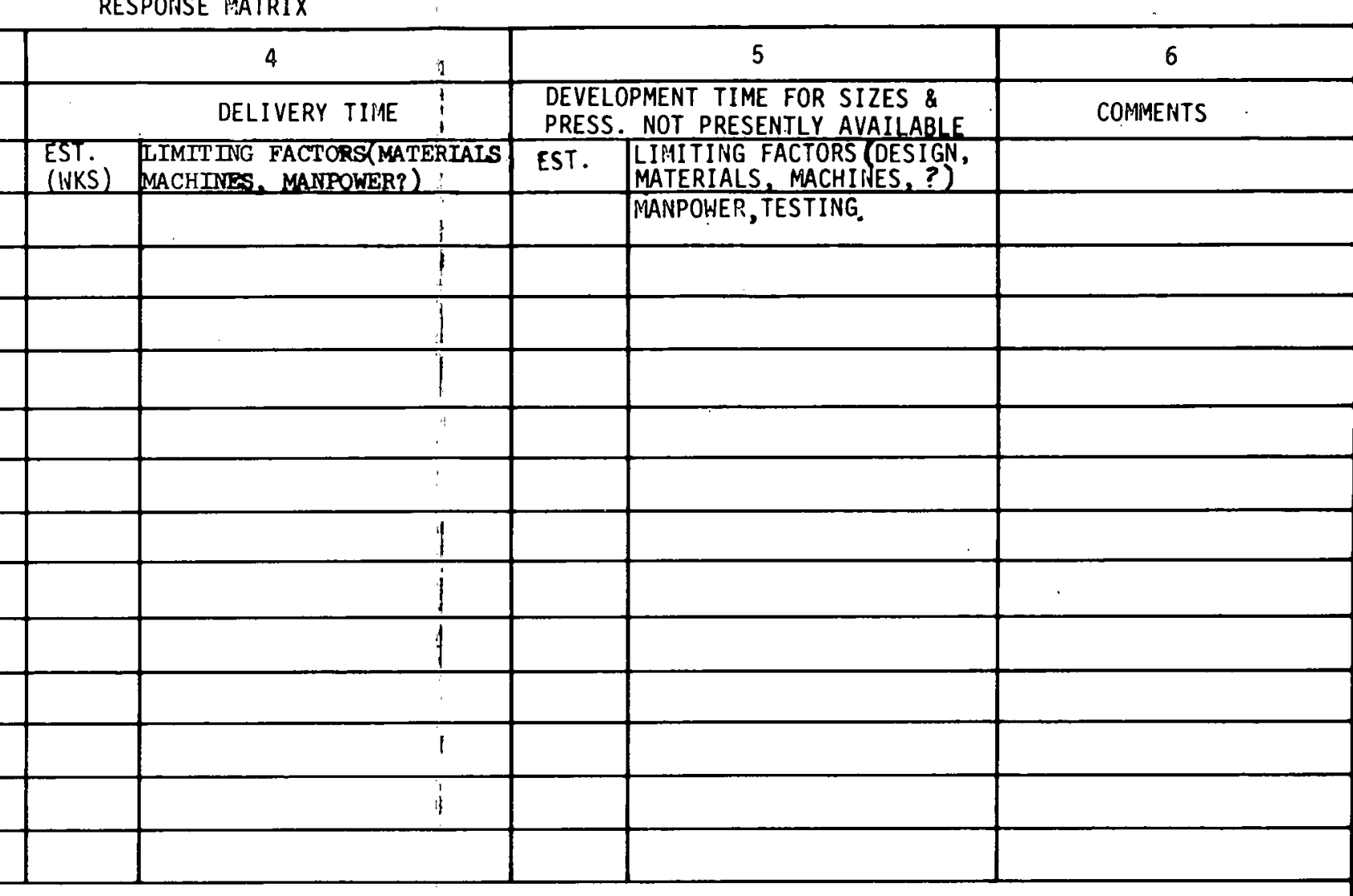

PROCESS DEFINITIONS.

1. MixTURES ARE ALL 50\% SOLIDS BY WEIGHT.

2. Coal size distribution "A" Means particles from minus 8 to plus 200 MESH.

3. COAL SIZE DISTRIBUTION "B" MEANS PARTICLE SIZES AND THEIR PERCENTAGES ARE

-8 TO $+12,0.45:+20,8.4:+30,6.4:+40,6.8:+60$,
$4.65:+200,5.6:+325,2.55:$ LESS THAN $325,2.9$.

4. CHAR MEANS COAL CHAR, SIZE $1 / 8^{\prime \prime} \times 0$

5. SLAG MEANS COAL SLAG RESIDUE $3 / 4 " \times 0$

6. GAS MEANS A COMBINATION OF GASES IN THE FOLLOWING PERCENTAGES:
CO, 3 TO $15: \mathrm{CO}_{2}, 3$ TO $15: \mathrm{H}_{2}, 6$ TO $40: \mathrm{CH}_{4}, 4$ TO $15: \mathrm{NH}_{3}, 1$ To 4
$\mathrm{H}_{2}, 10 \mathrm{O}$

* please furnish descriptive information 
Appendix D

SAMPLE LETTER OF INQUIRY TO BLAST/SLIDE/KNIFE F.RFF, VAT.VF, MANIIFACTIIRFERS 


\author{
OAK RIDGE NATIONAL LABORATORY \\ OPERATED BY \\ UNION CARBIDE CORPORATION \\ NUCLEAR DIVISION \\ CARtoiner \\ POST OFFICE BOX X \\ OAK RIDGE, TENNESSEE 37830 \\ June 24, 1977
}

Gentlemen:

The Unfted States Energy Research and Development Administration/Fossil Energy, Major Facilities Project Management Division is conducting an investigation of the capability of industry to provide valves for coal conversion facilities of demonstration and commercial scale. This study is being performed at the Oak Ridge National Laboratory by Union Carbide Nuclear Division. Industry input is desired in two areas:

1. defining the present capability of industry to supply the required valves,

2. determining research and development needs, including lead time requirements, for producing valves of advanced design.

An attachment including a capability questionnatre has been developed for the valve size and anticipated service applications. We hope that this will help provide the necessary information with a minimum of time and effort.

You are also invited to submit any additional ideas or suggestions which may help in making this investigation more beneficial to both governmental and industrial planners.

This is not a request for proposal; nor may it serve as a basis for any claim for reimbursement of costs for efforts expended. No remuneration will be provided; however, it is likely that this study will directly benefit the valve industry as well as the government and the public through normal government publication channels. Therefore, please do not supply any proprietary information.

We will appreciate your response to this questionnaire by July 30,1977 or earlier. If additional information or clarification is needed, please call me at (615) 483-8611, ext. 3-1416 or W. A. Bush at the same extcnoion.

Your help in this effort will be appreciated.

Very truly yours,

Edward C. Slade

UCC-ND Engineering

ECS : cr

Attachment 


\section{BACKGROUND}

Assuming that coal conversion will become a major industry within the next ten to fifteen years; this investigallun is attempting to assess the capability of, and to ascertain the impact that would be imposed upon the valve industry. At present, it appears that the coal conversion processes operate in the range of the present petrochemical. industry, except at the portion of the process where the coal is converted to gas, oil, and slag/char.

\section{INVESTIGATION AND REPORT}

As a part of this survey, we would like to obtain two sets of catalogs on your product line as would be applicable to the coal conversion industry. Your cooperation in filling out the attached. sheets will provide general information about your company and its products and an indication of which of your products fit within the unique requirements of the coal conversion processes. This listing of valve applications was compiled from prellminary conceptual designs of planned demonstration and commercial size and coal. conversion processes. Only those applications which appear to be the most stringent are listed. 


\section{1}

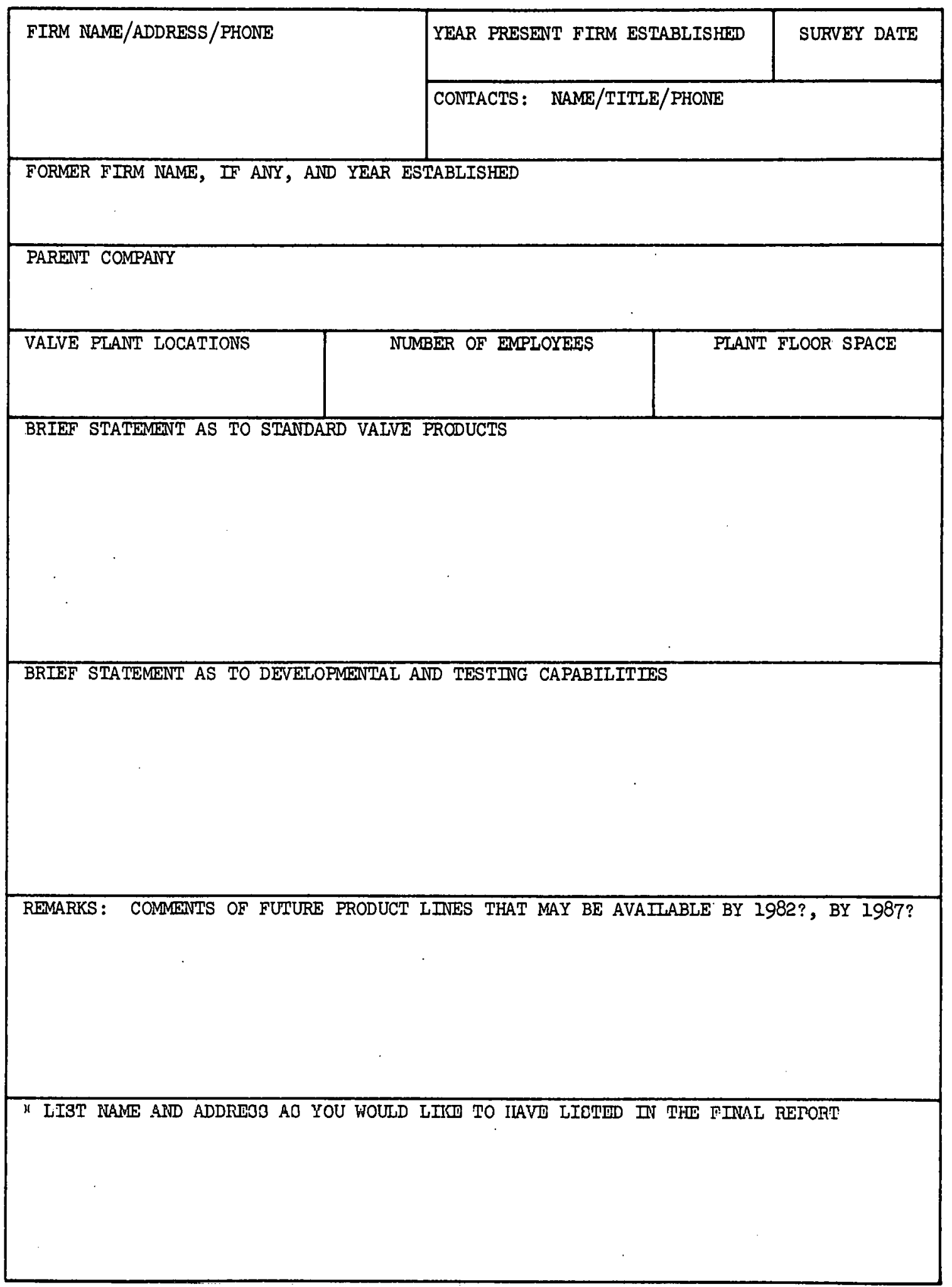


IN COAL CONVERSION PROCESSING PLANTS, BLAST/KNIFE EDGE TYPE VALVES MAY BE REEUIRED TO PERFORM FLON INTERRUPTION SERVICE ON TIONAL APPLICATIONS MAY BE TO ISOLATE MAJOR ITEMS OF EQUIPMEETT DURING SHUTDOHN AND MAINTENANCE.

THE VALVE BOOY CASING PRESSURES AND TEMPERATURES WOULD BE HIGH, BUT GAS DIFFERENTIAL PRESSURES WOULD BE MINIMAL. ABILITY TO
INTERRUPT FLOH, WITHSTAND THERMAL TRANSIENTS, STEM SEALING, RESIST EROSION AND ABILITY TO WITHSTAND CORROSIVE GASES :NOULD BE OF PRINCIPAL COMCRNS

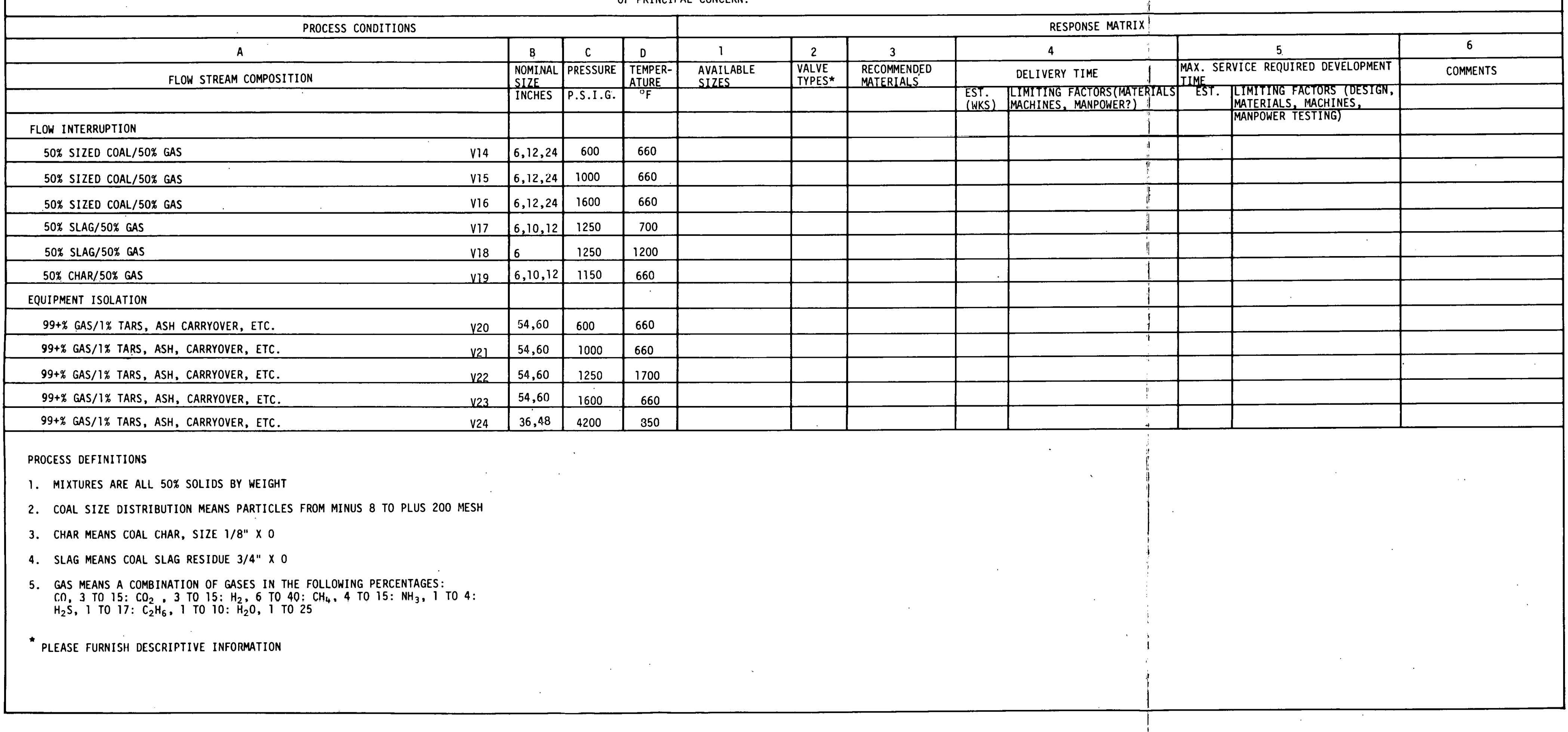


Appendix E

SAMPLE LETTER OF INQUIRY TO VALVE ACTUATOR MANUFACTURERS 


\author{
OAK RIDGE NATIONAL LABORATORY \\ OPERATED BY \\ UNION CARBIDE CORPORATION \\ NUCLEAR DIVISION \\ CARBon \\ POST OFFICE BOX $X$ \\ OAK RIDGE, TENNESSEE 37830 \\ July 15,1977
}

Gentlemen:

The United States Energy Research and Development Administration/Fossil Energy, Major Facilities Project Management Division is conducting an investigation of the capability of industry to provide valves for coal conversion facilities of demonstration and commercial scale. This study is being performed at the Oak Ridge National Laboratory by Union Carbide Nuclear Division. Industry assistance is being solicited in two areas:

1. defining the present capability of industry to supply the required valves and actuators,

2. determining research and development needs, including lead time requirements, for producing valves with actuators of advanced design.

Assuming that coal conversion will become a major industry within the next ten to fifteen years; this investigation is attempting to assess the capability of, and to ascertain the impact that would be imposed upon the valve-actuator industry. At present, it appears that the coal conversion processes operate in the range of the present basic metal and petrochemical industry, except at the portion of the process where coal is converted to gas and oil.

A study of several prospective coal conversion processes has shown that the valve requirements in the areas of concern are:

\begin{tabular}{|c|c|c|c|c|}
\hline $\begin{array}{l}\text { ACTUATOR-VALVE } \\
\text { TYPE }\end{array}$ & $\begin{array}{l}\text { SIZES } \\
\text { INCHES }\end{array}$ & $\begin{array}{l}\text { PROCESS } \\
\text { PRESSURE } \\
\text { PSI }\end{array}$ & $\begin{array}{l}\text { PROCESS } \\
\text { TEMP. } \\
{ }^{\circ} \mathrm{F} \\
\end{array}$ & FLOW STREAM \\
\hline \multicolumn{5}{|l|}{ Rotating } \\
\hline Gate, Globe & $6,12,24$ & 1150 & 600 & Oil, Water, Gas \\
\hline \multicolumn{5}{|l|}{$90^{\circ}$ Turn } \\
\hline Ball & $6,12,24$ & $1250,1600,4300$ & 660 & $\begin{array}{l}\text { Coalfines w/Gas } \\
\text { or 0il }\end{array}$ \\
\hline Ball & $6,10,12$ & 1250 & $700,1.600$ & Coal Ash w/Gas \\
\hline \multicolumn{5}{|l|}{ Straight } \\
\hline Blast, Gate & 48,60 & 1250 & $660,1200,1700$ & $\begin{array}{l}\text { Gummy Effluents } \\
\text { Coal Ash w/Gas }\end{array}$ \\
\hline
\end{tabular}


In these applications, the actuators would be located in either an outdoor location or a shed type enclosure and could be subjected to explosive vapors or explosive dust.

As a part of this investigation, we would like your cooperation in filling out the attached sheet regarding your company and its products and an indication of which of your products are most applicable fur critical applications in coal conversion processes. We would also like to obtain two sets of catalogs and descriptive information of this portion of your product line.

You arc invited to submit any ideas or suggestions which you consider helpful in making this investigation beneficial to both governmental and industrial piannèrs. We would particularly appreciate your thoughts on the need for governmental assistance for research and development, scale-up or testing of actuators.

This is not a request for proposals; nor may it serve as a basis for any claim for reimbursement of costs for efforts expended. No remuneration will be provided; however, it is likely that this investigation will directly benefit the valve-actuator industry as well as the government. The results of this. investigation will be published as a report that will be available to the public, through normal government publication channels. Therefore, please do not supply any proprietary information.

We will appreciate your response to this questionnaire by August 15, 1977 or earlier. If additional information or clarification is needed, please call me at (615) 483-861I, ext. 3-1416 or W. A. Bush at the same extension.

Your help in this effort will be appreciated.

Very truly yours,

Edward C. Slade

UCC-ND Engineering

ECS : cr

Attachment 


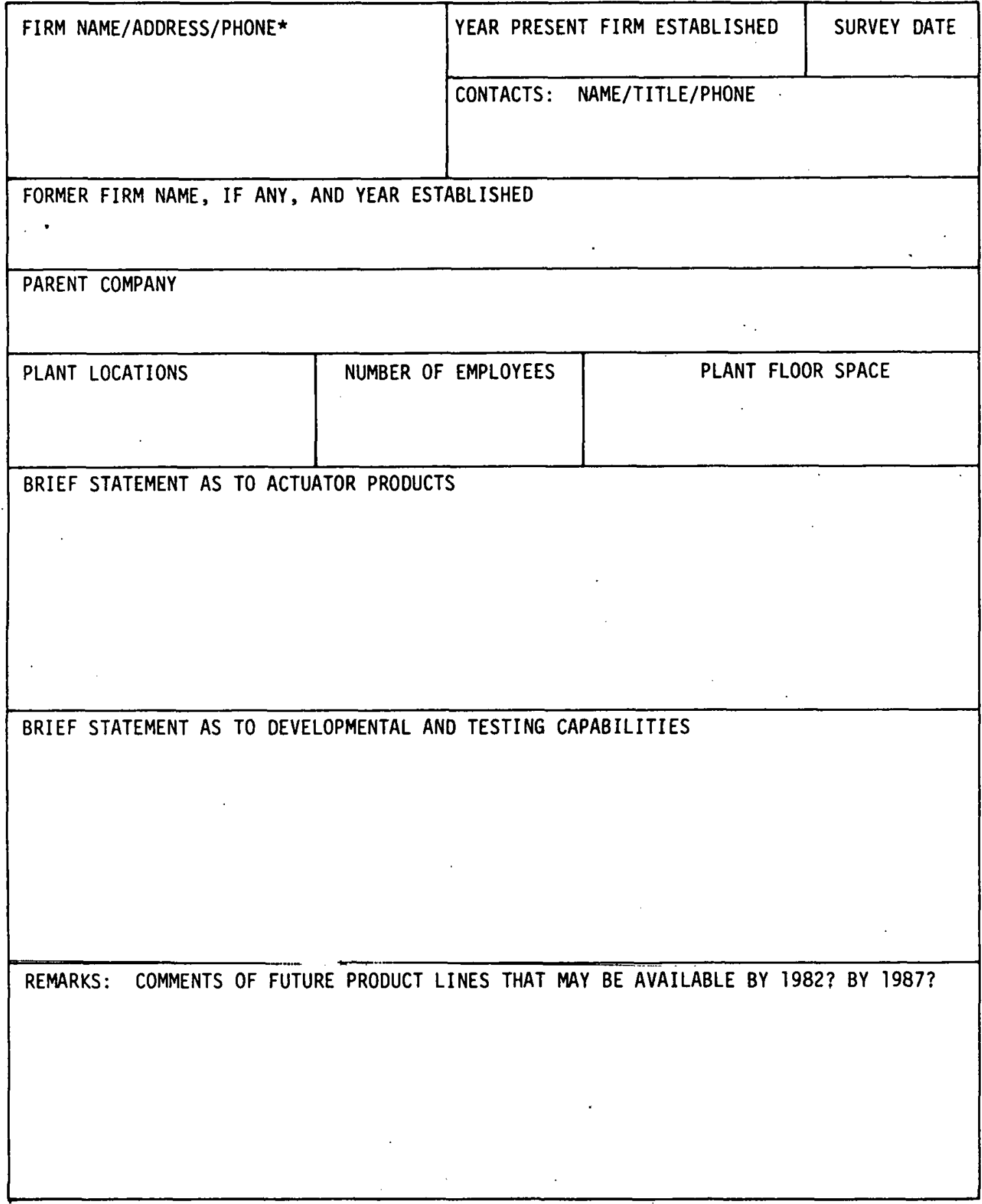

* LIST NAME AND ADDRESS AS YOU WOULD LIKE TO HAVE IT LISTED IN THE REPORT 
Appendix $\mathrm{F}$

VALVE SIZE DETERMINATIONS 
The conceptual designs ${ }^{1-7}$ of the selected coal conversion processes under development by DOE have not progressed to the delineation of the piping and valve sizes which would be used in commercial-sized plants. However, the conceptual designs do list the flowing media at various stages in the process, and from this data pipe and valve sizes can be estimated.

For the valve survey, the following approximation formulas were used to size the pipe diameter, and the valve diameter was assumed to equal the pipe diameter.

Liquid flow:

$$
d=0.1 \sqrt{\frac{w}{\rho}}
$$

where:

$$
\begin{aligned}
& d=\text { diameter, in. }, \\
& w=\text { flow, } 1 \mathrm{bs} / \mathrm{hr}, \\
& \rho=\text { density, } 1 \mathrm{~b} / \mathrm{ft}^{3} .
\end{aligned}
$$

Gas flow:

$$
Q=18.06 \frac{T_{0}}{P_{0}} \sqrt{\frac{\left(P_{1}{ }^{2}-P_{2}{ }^{2}\right) d^{5.33}}{G T L}},
$$

where:

$$
\begin{aligned}
& Q=\text { flow, } \mathrm{ft}^{3} / \mathrm{hr} \text { at } T_{0} \text { and } P_{0}, \\
& T_{0}=\text { base temperature, }{ }^{\circ} \mathrm{F}, \\
& P_{0}=\text { base pressure, psia }, \\
& P_{1}=\text { initial pressure, psia, } \\
& P_{2}=\text { final pressure, psia }, \\
& G=\text { specific gravity, }
\end{aligned}
$$




$$
\begin{aligned}
& T=\text { final temperature, }{ }^{\circ} \mathrm{F}, \\
& L=\text { length of pipe, ft/5280. }
\end{aligned}
$$

The following is an example of the use of these formulas, sizing a valve in the IGT HYGAS ${ }^{2}$ plant, reference valve V22 at the exit of Hydrogasifier (see Fig. 2).

$$
Q=18.06 \frac{T_{0}}{P_{0}} \sqrt{\frac{\left(P_{1}^{2}-P_{2}^{2}\right) d^{5 \cdot 33}}{G T L}},
$$

where:

$$
\begin{aligned}
& Q=809,000 \mathrm{ft}^{3} / \mathrm{hr}, \\
& T_{0}=T=600^{\circ} \mathrm{F}, \\
& P_{0}=\Gamma_{1}=1200 \mathrm{psid}, \\
& P_{2}=1170 \mathrm{psia}, \\
& L=200 / 5280 \mathrm{ft} \quad \text { (assumed) } \\
& G=0.38 \quad \text { (assumed) } \\
& Q=18.06 \frac{600}{1200} \sqrt{\frac{\left.1200^{2}-1170^{2}\right) d^{5.33}}{0.38 \times 600 \times 0.038},} \\
& d=44 \mathrm{in.} .
\end{aligned}
$$




\section{REFERENCES FOR APPENDIX F}

1. Energy Research and Development Administration, 250-MiZZion-SCFD High BTU Gas Plant, ERDA 76-48, Process Evaluation Group - Mineral and Material Research and Development, Morgantown, W. Va. (March 1976).

2. Energy Research and Development Administration, IGT HYGAS Hydrogasification Process, ERDA 76-47, Process Evaluation Group - Mineral and Material Research and Development, Morgantown, W. Va. (March 1976).

3. The R. M. Parsons Company, Fischer-Tropsch Complex Conceptual Design/ Economics Analysis: Oil and SNG Production. R\&D Report No. 114 Interim Report No. 3, FE-1775-7, Pasadena, Calif. (January 1977).

4. Energy Research and Development Administration, 250-MizZion-SCFD Gas Plant, ERDA 76-7, Process Evaluation Group - Mineral and Material Research and Development, Morgantown, W. Va. (August 1975).

5. E. T. Coles, Commercial Plant Process Evaluation Report, report prepared under Contract No. E(49-18)-1736 with Energy Research and Development Administration, New York (August 1975).

6. J. M. Holmes et al., Hydrocarbonization Process Evaluation Report, ORNL-5212 (Draft), (September 1976).

7. R. Salmon et al., Evaluation of the Synthoil Process, ORNL-5209, (September 1976). 
ORNL/TM-6071

\section{INTERNAL DISTRIBUTION}

1. T. M. Andress

2. W. B. Andrews

3. W. J. Armento

4. H. C. Beeson

5. M. Bender

6. W. F. Boudreau

7-46. W. A. Bush (40)

47. D. A. Canonico

48. H. D. Cochran

49. B. F. Crump

50. I. T. Dudley

51. M. S. Edwards

52. 0. J. Farley

53. J. F. Fisher

54. J. Foster

55. J. T. Fowler

56. W. R. Gambill

57. R. W. Glass

58. A. R. Godsey

59. H. F. Hartman

60. D. W. Hatcher

61. J. M. Holmes

62. J. R. Horton

63. J. K. Huffstetler

64. G. R. Jasny

65. J. E. Jones, Jr.

66. J. R. Joplin

67. D. R. Kellog

68. R. T. King

69. J. J. Kurtz

70. R. E. Lampton

71. C. C. Littlefield

72. R. E. MacPherson
73-76. L. E. McNeese (4)

77-80. J. R. McWherter (4)

81. J. P. Meyer

82. R. P. Milford

83. I. K. Namba

84. J. P. Nichols

85. B. Niemann

86. J. A. Parsons

87. F. S. Patton

88. G. R. Peterson

89. T. W. Pickel

90. W. Pokela

91. W. R. Reed

92. G. W. Renfro

93. M. W. Rosenthal

94. R. Salmon

95. C. D. Scott

96. T. Shapiro

97. S. P. N. Singh

98. M. Siman-Tov

99-108. E. C. Slade (10)

109. C. B. Smith

110. L. H. Stinton

111. C. B. Tolliver

112. W. C. Ulrich

113. J. E. Vasgaard

114. W. R. Williams

115-116. Central Research Library

Document Reference Section

117-118. Lab Records Dept.

119. Lab Records - ORNL RC

120. ORNL Patent Office

121-123. Technical Publications 


\section{EXTERNAL DISTRIBUTION}

124. W. J. Alberti, Teledyne Farris Engineering, 400 Commercial Avenue, Palisades Park, NJ 07650

125. E. E. Allen, Fisher Controls Company, P. 0. Box 190, Marshalltown, IA 50158

126. L. D. Anson, Environmental Elements Corporation, 3700 Koppers Street, P. O. Box 1318, Baltimore, MD 21203

127. R. Antonsen, Department of Energy, Washington, DC 20545

128. L. Arranaga, Arral Industries, Inc., 6161 Cedros Avenue, Van Nuys, CA 91411

129. W. S. Askew, Gilbert Associates, 1828 L Street NW, Washington, DC 20036

130. T. Atwood, Department of Energy, Washington, DC 20545

131. W. T. Bakker, Department of Energy, Washington, DC 20545

132. R. J. Basile, Exxon Research and Engineering Company, P. 0. Box 101, Florham Park, NJ 07932

133. J. Batchelor, Department of Energy, Washington, DC 20545

134. R. J. Beckers, Becker Precision Equipment, Inc., 75 Randall Street, tilk lrove, IL b0007

135. P. R. Beswick, Beswick Engineering, 26 Browaville, Ipswich, MA 01938

136. J. C. Bixel, Monsanto Research Corp., Mound Facility, Box 5555, Miamisburg, $\mathrm{OH} 45342$

137. R. C. Boedecker, Worcester Controls Corporation, 125 Hartwell Street, W. Boylston, MA 01583

138. D. H. Boehm, RACO International, Inc., 3350 Industrial Blvd., Bethel Park, PA 15102

139. E. C. Breidert, Paducah Gaseous Diffusion Plant, P. O. Box 1410, Paducah, KY 42001

140. M. R. Bruck, Gas Machinery Division, 336 S. Spring St., Port Washington, WI 53074

141. E. C. Busfield, Ametek/Schutte \& Koerting Division, Cornwells Heights, PA 19020

142. M. L. Cardwel1, Roto Hammer Co., P. O. Box 9308, Tulsa, OK 74107

143. S. J. Caroleo, Kerotest Manufacturing Corp., 2525 Liberty Avenue, Pittsburgh, PA 15222

144. M. A. Christensen, Department of Energy, Washington, DC 20545

145. E. L. Clark, Department of Enèrgy, Washington, DC 20545

146. Olin Colitti, Department of Energy, Washington, DC 20545

147. P. Coster, Cleveland Armstrong Co., 1108 S. K1lburn, Chicago, IL 60624

148. F. L. Culler, Electric Power Research Institute, P. O. Box 10412, Palo Alto, CA 94303

149. W. C. Dackis, Crane Co., 300 Park Avenue, New York, NY 10022

150. C. A. Dally, Dally Engineering-Valve Co., 1200 Century Building, Pittsburgh, PA 15222

151. E. G. Davis, Andco Industries, Inc., 20005 Walden Ave., Buffalo, NY 14240

152. R. S. Dickert, Henry Valve Co., 3215 North Avenue, Melrose Park, IL 60160

153. M. C. Donze, Limitorque Corp., 5114 Woodall Road, Lynchburg, VA 24502 
154. D. Dubus, Pittsburgh Energy Research Center, 4800 Forbes Avenue, Pittsburgh, PA 15213

155. D. J. Easton, Everlasting Valve Company, 70 Myrtle Street, Cranford, NJ 07016

156. J. P. Ellenberger, Clow Corporation, 40 Chestnut Ave., Westmont, IL 60559

157. L. H. Elliott, EIM Company, Inc., 13840 Piake Road, Missouri City, TX 77459

158. J. T. Emery, Honeywe11, Inc., 1100 Virginia Drive, Ft. Washington, PA 19034

159. P. F. Etsas, TXT/Division Vapor Corp., 320 Hughes Street, P. 0. Box 9369, Houston, TX 77011

160. A. W. Fages, Rockwell International, 400 N. Lexington Ave., Pittsburgh, PA 15208

161. H. J. Fitzpatrick, Royal Industries, 2040 E. Dyer Road, Santa Ana, CA 92705

162. R. Fix, R. A. Angle Technology Center, P. 0. Box 11, Marshal1town, IA 50158

163. J. J. Forst, Department of Energy, Washington, DC 20545

164. Zola Fox, Fox Valve Development Co., 2 Great Meadow Lane, Hanover, NJ 07936

165. H. E. Frankel, Department of Energy, Washingtuin, DC 20545

166. C. H. Freudenrich, Blaw-Knox Equipment; Inc., P. O. Box 11450, Pittsburgh, PA 15238

167. W. P. Gadient, Sulzer Bros., Inc., 19 Rector Street, New York, NY 10006

168. J. F. Gardner, Morgantown Energy Research Center, P. 0. Box 880, Morgantown, WV 26505

169. D. Garrett, Department of Energy, Washington, DC 20545

170. R. A. Genier, Atwood \& Morrill Co., 285 Canal Street, Salem, MA 01976

171. R. D. Gladding, Abex Corporation, Valley Road, Mahwah, NJ 07430

172. V. S. Glowacki, J. E. Lonergan Co., P. O. Box 6167, Philadelphia, PA 19115

173. M. R. Gray, The Carborundum Company, P. O. Box 337, Niagara Fal1.s, NY 1.4302

174. T. G. Gsell, Zidell Explorations, Inc., 3121 SW Moody Ave. Portland, OR 97201

175. J. O. Hendrickson, The Valve Manufacturers Association, Drawer II, McLean, VA 22101

176. J. P. Herron, Tufline Division, Xomox, 4444 Cooper Road, Cincinnati, OH 45242

177. J. M. Hobday, Morgantown Energy Research Center, P. O. Box 880, Morgantown, WV 26505

178. W. H. Hopf, Walworth Company, P. O. Box 873, Vallcy Forge, PA 19482

179. G. E. Huse, C-E Invalco, P. O. Box 556, 1305 N. Louisville, Tulsa, OK 74101

180. T. E. Jackson, Consolidated Controls Corp., 2338 Alaska Ave., E1 Segundo, CA 90245

181. J. V. James, Dresser Industries, P. 0. Box 718, Dallas, TX 7522.1. 
182. W. M. Janik, Raymond Control Systems, 315. Kirk Road, St. Charles, IL $6017 /$

183. H. W. Johnson, CODECAL, Inc., P. O. Box 428, Summit, NJ 07901

184. G. L. Jones, Willis Oil Tool Company, 2451 Palm Drive, P. 0. Box 7367, Long Beach, CA 90807

185. H. T. Jones, Department of Energy, Washington, DC 20545

186. H. H. Kaemmer, Automatic Switch Co., Hanover Road, Florham Park, NJ 07932

187. Victoria Kaminski, TAPCO International, Inc., 14309 Sommermeyer, P. O. Box 40472, Houston, TX 77040

188. P. G. Kindersley, Kamyr Valves, Inc., Ridge Center, Glen Falls, NY 12801

189. B. Klopfenstein, Keystone Valve Division, $9700 \mathrm{~W}$. Gulf Bank Drive, P. O. Box 40010, Houston, TX 77040

1.90. R. Koester, The Wm. Powell Co., 2503 Spring Grove Ave., Cincinnati, OH 45214

191. F, K, Krell, Ladish Co., 5481 S. Packard Ave., Cudahy, WI 53110

192. R. A. Kuiper, Lockheed Pal Alto Research Laboratory, 3251 Hanover Street, Palo Alto, CA 94304

193. A. Latham, Rockwood Systems Corp., 80 Second St., So. Portland, ME 04102

194-233. T. K. Lau, Department of Energy, Washington, DC 20545

234. A. R. Laugier, Cameron Iron Works, Inc., P. 0. Box 1212, Houston, TX 77001

235. W. M. Lee, AiResearch Mfg. Co., 402 S. 36th Street, Phoenix, AZ 85034

236. J. A. Lenhard, Department of Energy, Oak Ridge, TN 37380

237. L. Leon, Halliburton Services, Drawer 1431, Duncan, OK 73533

238. R. K. Little, RKL Controls, Inc., Hainesport Industrial Park, Hainesport, NJ 08036

239. R. Llttle, MCC lorapac, 1900 W. Dempsters, Evanston, IL 60204

240. W. D. Louoko, Valtak Incorporated, 765 South 1 .nก East., Provn, UT 84601

241. D. M. Luntz, Department of Energy, Washington, DC 20545

242. T. J. McCuistion, Parker-Hannifin Corp., 17327 Eucl1d Ave., Cleveland, $\mathrm{OH} 44112$

243. L. J. Milberger, FMC Corporation, 1717 Greens Road, P. 0. Box 3091, Houston, TX 77001

244. M. Miller, Falrchild Stratos Div., 1800 Rosecrans Ave., Manhattan Beach, CA 90266

245. J. T. Milloway, Jr., Department of Energy, Oak Ridge, TN 37380

246. J. A. Moore, The Oil Daily, 827 National Press Bldg., Washington, DC 20045

247. C. E. Muller, Dresser Industrial Valve \& Instrument Division, 250 East Main St., Stratford, CT 06497

248. B. R. Murphree, Peabody Dore' Corp., P. O. Box 42081, Houston, TX 77042

249. A. Murphy, Jet Propulsion Laboratory, Pasadena, CA 91109

250. W. E. Murphy, 500 W. Eldorado, Mueller Co., Decatur, IL 62525

251. T. J. Nakley, Department of Energy, Washington, DC 20545

252. M. Neuworth, Department of Energy, Washington, DC 20545 
253. R. W. Newman, Newbrook Machine Corp., 16 Mechanic St., Silver Creek, NY 14136

254. R. L. Nightwine, Specialty Valve \& Controls, Inc., 8150 W. Ridge Road, Fairview, PA 16415

255. R. P. Nooney, ITT Grinnell Valve Div., 1021 E. Water St., Elmira, NY 14901

256. H. D. Olson, DeZurik, A Unit of General Signal, Sartel1, MN 56377

257. J. Pasini, Morgantown Energy Research Center, P. O. Box 880, Morgantown, WV 26505

258. D. C. Pass, Rotork Controls, Inc., 19 Jet View Drive, Rochester, NY 14624

259. J. G. Patel, Institute of Gas Technology, 3424 S. State Street, Chicago, IL 60616

260. R. Phen, Jet Propulsion Laboratory, Pasadena, CA 91109

261. W. Pietrucha, Coal Industry News, 20 Community Place, Morristown, NJ 07960

262. A. A. Pitrolo, Morgantown Energy Research Center, P. 0. Box 880 , Morgantown, WV 26505

263. D. E. Platt, Contromatics Div., Litton Industrial Products, 222 Roberts Street, East Hartford, CT 06108

264. A. E. Plow, TK Valve \& Manufacturing, Inc., P. O. Box 308, Hammond, LA 70404

265. S. J. Poss, Stockham Valve \& Fittings, P. 0. Box 10326, Birmingham, AL 35202

266. J. W. Post, Kieley and Mueller, Inc., 64 Genung Street, Middletown, NY 10940

267. J. L. Powell, Department of Energy, Washington, DC 20545

268. W. K. Priese, Hills-McCanna Co., 400 Maple Ave., Carpentersville, IL 60110

269. L. L. Radcliffe, Department of Energy, Oak Ridge, TN 37380

270. G. Raftis, Red Valve Company, 500 Bell Ave., Carnegie, PA 15106

271. H. E. Rains, The Lunkenheimer Co., P. O. Box 14360, Cincinnati, OH 45214

272. G. L. Rice, Sperry Vickers, 1401 Crooks Road, Troy, MI 48044

273. A. M. Ritter, Fetterolf Corp., P. O. Box 156, Fairview Village, PA 19409

274. R. Kodwancy, Shan-Rod Inc., Driver Rd., Berlin Heights, OH 44814

275. K. Rogers, CALMEC, 8401 E. Slauson, Pico Rivera, CA 90660

276. G. S. Rosenberg, Argonne National Laboratory, Argonne, IL 60439

277. J. R. Santoro, Westinghouse Electro-Mechanical Div., Cheswick Ave., Cheswick, PA 15024

278. J. C. Schaff, Bettis Corporation, P. O. Box 14689, Houston, TX 77021

279. J. R. Schlereth, Anchor/Darling Valve Co., One Belmont Avenue, Bala Cynwyd, PA 19004

280. D. D. Schumann, Andco Actuator Products, Inc., 2005 Walden Ave., P. O. Box 988, Buffalo, NY 14246

281. J. W. Sigmon, Sigmon Corporation, 4425 Randolph Road, Charlotte, NC 28211

282. T. B. Simpson, Department of Energy, Washington, DC 20545

283. H. M. Sipe, Circle Seal Controls, P. O. Box 3666, Anahe1m, CA 92803 
284. G. C. Sine, Energy Systems Group of TRW, Inc., 918 Chestnut Ridge Road, Morgantown, WV 26505

285. L. Slaughter, Anderson, Greenwood \& Co., 5425 S. Rice Ave., Houston, TX 77081

286. A. D. Smith, Smith Valve Corporation, 125 Fisher Street, Westboro, MA 01581

287. J. Smith, Department of Energy, Washington, DC 20545

288. D. Strimbeck, Morgantown Energy Research Center, P. O. Box 880 , Morgantown, WV 26505

289. A. H. Strom, Department of Energy, Washington, DC 20545

290. C. Sutherland, Gould Inc., $6300 \mathrm{~W}$. Howard St., Chicago, IL 60648

291. G. R. Sweitzer, GEMCO, The General Machine Co. of NJ, 55 Evergreen Ave., Newark, NJ 07114

292. '1'. H. Teplow, Crusby Valve \& Gage Company, 43 Kendrick St., Wrentham, MA 02093

293. D. Tooley, Fabri-Valve, P. O. Box 4367, Portland, OR 97208

294. F. R. Trescott. Department of Energy, Washington, DC 20545

295. P. P. Van Blarcom, Yarway Corp., Blue Bell, PA 19422

296. R. A. Verner, Department of Energy, Washington, DC 20545

297. C. W. Ward, Bellows International, 200 W. Exchange St., Akron, OH 44309

298. H. Weisenfeld, Department of Energy, Washington, DC 20545

299. F. E. Westermann, Binghamm-Willamette Company, 2800 NW Front Ave., Portland, OR 97210

300. A. M. Williamson, ACF Industries, W-K-M Valve Div., P. 0. Box 2117, Houston, TX 77001

301. W. J. Wnuk, FMC Corporation, 1803 Greens Road, P. O. Box 4270, Houston, TX 77210

302-328. Technical Information Center, DOE-ORO 